\title{
Client-centred care : balancing between perspectives of clients and nurses in home care
}

Citation for published version (APA):

Schoot, C. M. (2006). Client-centred care : balancing between perspectives of clients and nurses in home care. [Doctoral Thesis, Maastricht University]. Datawyse / Universitaire Pers Maastricht. https://doi.org/10.26481/dis.20061020cs

Document status and date:

Published: 01/01/2006

DOI:

$10.26481 /$ dis.20061020cs

Document Version:

Publisher's PDF, also known as Version of record

\section{Please check the document version of this publication:}

- A submitted manuscript is the version of the article upon submission and before peer-review. There can be important differences between the submitted version and the official published version of record.

People interested in the research are advised to contact the author for the final version of the publication, or visit the DOI to the publisher's website.

- The final author version and the galley proof are versions of the publication after peer review.

- The final published version features the final layout of the paper including the volume, issue and page numbers.

Link to publication

\footnotetext{
General rights rights.

- You may freely distribute the URL identifying the publication in the public portal. please follow below link for the End User Agreement:

www.umlib.nl/taverne-license

Take down policy

If you believe that this document breaches copyright please contact us at:

repository@maastrichtuniversity.nl

providing details and we will investigate your claim.
}

Copyright and moral rights for the publications made accessible in the public portal are retained by the authors and/or other copyright owners and it is a condition of accessing publications that users recognise and abide by the legal requirements associated with these

- Users may download and print one copy of any publication from the public portal for the purpose of private study or research.

- You may not further distribute the material or use it for any profit-making activity or commercial gain

If the publication is distributed under the terms of Article $25 \mathrm{fa}$ of the Dutch Copyright Act, indicated by the "Taverne" license above, 
CLIENT-CENTRED CARE

Balancing between perspectives of clients and nurses in home care 
The publication of this thesis was financially supported by Hogeschool Zuyd, Nolet Consultancy BV, Orbis medisch en zorgconcern (divisies Maaslandziekenhuis en Thuiszorg Westelijke Mijnstreek), ThiemeMeulenhoff Utrecht.

Cover illustration: M.C. Escher's "Symmetry Drawing E18"

(C) 2005 The M.C.Escher Company B.V. Baarn-Holland. All rights reserved. Layout and printing: Datawyse boekproducties Maastricht

ISBN-10: 90-5278-561-9

ISBN-13: 978-90-5278-561-5

Universitaire Pers Maastricht

Copyright (C) Tineke Schoot, Maastricht, 2006

All chapters previously published are reprinted with the permission of the original copyright holders.

The study presented in this thesis was financially supported by the Netherlands Organization for Health Research (ZonMw), projectnumber 3206.0103; by Centraal Fonds RVVZ the Netherlands and by Zuyd University Heerlen the Netherlands. 


\section{CLIENT-CENTRED CARE}

\section{Balancing between perspectives of clients and nurses in home care}

Proefschrift

ter verkrijging van de graad van doctor

aan de Universiteit Maastricht,

op gezag van de Rector Magnificus Prof.mr. G.P.M.F. Mols

volgens het besluit van het College van Decanen

in het openbaar te verdedigen

op vrijdag 20 oktober 2006 om 12.00 uur

door

Christina Maria Schoot

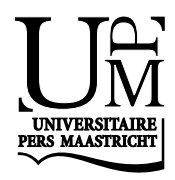




\section{Promotor}

Prof.dr. R.H.J. ter Meulen (University of Bristol, United Kingdom)

\section{Copromotores}

Dr. L.P. de Witte

Dr. I.M. Proot

\section{Beoordelingscommissie}

Prof.dr. C. Spreeuwenberg (voorzitter)

Dr. C. Gastmans (Katholieke Universiteit Leuven)

Prof.dr. M.H.F.Grypdonck (Universiteit Utrecht)

Prof.dr. J.P.H. Hamers

Prof.dr. H.Philipsen 


\section{CONTENTS}

Chapter 1 General Introduction 7

1.1 Background 8

1.2 Client-centred care 9

1.3 Chronically Ill people receiving long-term care 17

$\begin{array}{lll}1.4 & \text { Home nursing care } & 18\end{array}$

1.5 Nurse's competencies and development of competencies 19

1.6 Context of the study 20

1.7 Methodological considerations 22

1.8 Outlines of the thesis 23

References $\quad 25$

\section{PART I PERSPECTIVES ON CLIENT-CENTRED CARE 31}

Chapter 2 Recognition of client values as a basis for tailored care:

The view of Dutch expert patients and family caregivers 33

Chapter 3 Actual interaction and client-centredness in home care 51

Chapter 4 Client-centred home care: Balancing between competing responsibilities

PART II TOWARDS A LEARNING PROGRAMME AIMED AT CLIENT-CENTRED CARE

Chapter 5 Het ontwerp van een leertraject in samenspraak: Naar een leertraject vraaggerichte zorg op basis van het 'Acht velden model' van Kessels

PART III EVALUATION OF THE LEARNING PROGRAMME AIMED AT CLIENT-CENTRED CARE

Chapter 6 Zelfbeoordeling van competenties voor vraaggerichte zorg in de thuiszorg. De ontwikkeling van de 'Zorg in dialoog Competentie Schaal'

Chapter 7 Development of the client-centred care questionnaire

Chapter 8 Development of competencies aimed at client-centred care: An evaluation study

Chapter 9 General Discussion 
9.1 Introduction 170

$\begin{array}{lll}9.2 & \text { Main results of the study } & 170\end{array}$

9.3 Theoretical reflections 181

9.4 Ethical reflections 185

9.5 Methodological reflections 191

9.6 Implications and recommendations 197

References 202

Summary 207

Samenvatting 216

Dankwoord 225

Curriculum Vitae 229

Publications 230 
1 GENERAL INTRODUCTION 


\subsection{BACKGROUND}

Client-centred care is a buzz-word. Everybody talks about it. Client-centred care is increasingly regarded as a proxy for high quality, interpersonal care (Mead \& Bower, 2000a). The change into client-centred care has also been described as one from a provider-oriented model of care into a client-centred model of care (Bosselaar, van der Wolk, Zwart, \& Spies, 2002; Chewning \& Sleath, 1996, Tonkens 2003). Client-centred care has gained increased importance in health care in many Western countries (Chewning \& Sleath, 1996; Donaldson, 2001; Latvala, 2002; SFS, 1982; WHO, 1996). In the Netherlands, concepts such as 'demand-oriented care', 'demand-led care', 'demand-driven care', and emotionoriented care, have surfaced in health care literature as client-centred concepts of care and service delivery that place the individual client at the centre of care (Goudriaan \& Vaalburg, 1998; van der Kraan, 2001). Government policy aims at putting client-centred care into practice (NCCZ, 1999; RVZ, 1998; Terpstra,1997). With all stakeholders involved, in all health care sectors, at all levels, efforts are seen to realize client-centred care (Bosselaar et al., 2002; Goudriaan \& Vaalburg, 1998; KITTZ, 2004; Verbeek \& Tiemersma, 1998). Client-centred care also requires changes in the role and competencies of the professional caregiver (HGZO, 2000; Pool et al., 2001; RVZ, 2000; VWS, $2000 ;$ ).

Mead and Bower (2000a) state that while strong moral and clinical justifications about the application of the concept have been advanced, there is a lack of consistency about the concept of 'client-centred care', partly because it has been defined in various ways. Substantial differences seem to exist, in the underlying meaning that is attributed to the distinct concepts by stakeholders involved. Many authors have highlighted the confusion about the meaning of these new care concepts, at the expense of the introduction of these concepts in practice (Little, Everitt, Williamson, Warner, Moore, Gould, 2001; Mead \& Bower, 200b; Rijckmans, Garretsen, Bongers \& van de Goor, 2002; Stewart, 2001; van der Kraan, 2001). Apparently, improving client-centred care is not that easy.

This thesis reports on a research project into client-centred care in the context of the primary process of nursing home care for chronically ill clients.

The project started with the following general research questions:

What does client-centred care encompass in the context of the primary process of home care for chronically ill clients? Which competencies are required in nurses with respect to client-centred care? And can these competencies be developed? 
The goal of the research project was to contribute to the quality of care and the quality of life of chronically ill people. The short-term purposes of the study were twofold: to provide input for a learning programme aimed at developing competencies of home-care nurses needed for client-centred care, and secondly, examining if the performance of nurses' competencies with respect to client-centred care can be measured and developed.

The studies discussed in this thesis were guided by the following sub-questions:

- what is the client's perspective on client-centred care?

- what is the nurse's perspective on client-centred care?

- how can one develop an internally and externally consistent learning programme aimed at development of competencies in nurses with respect to client-centred care?

- how the nurse's performance of the competencies can be measured?

- how the client-centredness as perceived by clients can be measured?

- what is the impact of the learning programme?

- which factors influence the nurses' development and performance of the competencies?

The term 'nurses' also covers auxiliary nurses. This introduction will be continued by clarifying the various concepts that are used in the research questions: client-centred care, chronic illness, long-term care, home nursing care, nurse's competencies and development of competencies. The context of the study, as well as the methodological considerations and the outlines of this thesis will be described at the end of this chapter.

\subsection{CLIENT-CENTRED CARE}

\subsubsection{Introduction}

Client-centred care exists under a variety of names, such as: patient-centred care, person-centred care, family-centred care, demand-oriented care. Equivalents for 'centred' are 'oriented' or 'focused'. Client-centred care has many faces. This section will be started with international differences noted in the use of the concept of client-centred care. Then, an overview of client-centred concepts of care used in literature will be provided.

Of all existing client-centred concepts of care, demand-led care is seen as the most extreme form. A provider-oriented approach is considered as the opposite: 'what it is not'. The clarification of the underlying meaning of the distinct concepts will be started with these two extremes: a provider-oriented approach (section 1.2.4) and demand-led care (section 1.2.5). Demand-oriented care can be positioned between these extremes (section 1.2.6). The clarification of the concepts will be 
based upon the following dimensions: central perspectives, aims, roles and responsibilities, decision making and the context of the situation in which the concept is used. Table 1 shows several of the characteristics of client-centred concepts for the primary process of care discussed.

After clarifying the distinct concepts, the roots of client-centred concepts of care will be considered.

\subsubsection{International differences}

At present, many 'client-centred concepts of care' are in force. In the Netherlands, the concepts 'vraaggerichte zorg' (literally translated as 'demand-oriented care') and 'vraaggestuurde zorg' (literally translated as 'demand-led care' or 'demand-driven care') are frequently used (van der Kraan, 2001, Bosselaar et al. 2002, Goudriaan \& Vaalburg 1998, Tonkens, 2003). In the literature in English, however, these concepts are mainly used in social-political discussions at a mesoand macro-level, concerning allocation and financing of health care (Verkooijen et al., 2003). The literature on client-centredness demonstrates that client satisfaction increases when professionals focus on client perspectives and take their ideas, concerns and expectations into account (Lewin, Skea, Entwistle, Zwarenstein, \& Dick, 2001; Roter, 1989). Besides quality purposes, however, the concepts used in the Netherlands are also promoted from an economic viewpoint. They are expected to lead to a better adjustment of the demand, and therefore to induce efficiency (Goudriaan \& Vaalburg, 1998; Bosselaar et al., 2002; Ministerie VWS, 1999; Tonkens, 2003). The Dutch emphasis on 'demand' results from the concept 'tailored care', which has acquired two meanings: tailored to the individual demand, and an economic angle, "not too much, and not too expensive" (Goudriaan \& Vaalburg, 1998, p.13). Another explanation for the use of the Dutch concept of 'demand-oriented care' may be the emphasis on the efforts of both the professional and the client (Verbeek, 1999). The concepts of demandoriented care and demand driven care emphasize the efforts of both parties: the client has to express his demand, and the provider has to align care to the client demand. Additionally, in English speaking countries, the concepts of 'client participation' and 'shared decision making' are used frequently to illustrate the two-sided character of the care process (Cahill, 1998; Elwyn, 2001). In this dissertation the term 'client-centred care' will be used instead of 'patient-centred care', to express the equality of patient and provider of care.

\subsubsection{Client-centred care: aspects and degrees}

Various client-centred concepts of care have been mentioned. All these concepts have in common that they put the client, patient or family at the centre of the care process (Chewning \& Sleath, 1996; Elwyn, 2001; van der Kraan, 2001). Their 
aim is to focus on individualized care. Hobson, however, states that clientcentred care is equally subject to various degrees (Hobson, 1996). Of all existing client-centred concepts of care, demand-led care is seen as the most extreme form (Goudriaan \&Vaalburg, 1998; van der Kraan, 2001).

In the words of Gage and Polatajko (1995): "client-centred practice has been described as everything from considering the client's needs when making treatment decisions or having the client direct the care planning process"(Gage \& Polatajko, 1995, p. 116). Several aspects of client-centred care can be identified from the literature. A Cochrane review of studies that evaluated interventions intended to promote client-centred care in clinical settings, including nursing care, revealed two main features of client-centred care: shared control of decisions about interventions or management of the health problems and/or focus on the patient as a whole individual within a social context (Lewin et al. 2001). A review of conceptual and empirical medical literature (Mead \& Bower, 2000b) reveals five conceptual dimensions: biopsychosocial perspective, patient as a person, sharing power and responsibility, therapeutic alliance and professionalas-person. Little et al.'s (2001) study reveals that clients want client-centred care which explores the client's concerns and needs; seeks an integrated understanding of the client's whole person's world; finds a common ground as to what the problem is and mutually agrees on the management; enhances prevention and health promotion; enhances the continuing relationship with the professional.

\subsection{4 'What it is not': a provider-oriented approach}

Client-centred care may be most commonly understood by describing what client-centred care is not: a provider-oriented approach, professional-oriented care, provider-led care, supplier-driven care, professional-directed care, medical-centred care, disease-centred care or diagnosis-based care (see table 1). Authoritarian care, paternalism, priestly and parental care, are related terms that also describe what client-centred care is not (Chewning \& Sleath, 1996; Latvala, 2002; Emmanuel \& Emmanuel, 1992).

Bosselaar et al., (2002) distinguish three angles to describe a provider-oriented approach: a political-economical perspective, a social-political perspective and an institutional perspective. The political-economical perspective concerns the relationship between the provider of care (care organizations) and the client. A provider-oriented approach from this perspective is characterized by the central position of the government in allocating care (the right care for the right people), as exemplified by terms such as 'the welfare state'. In this perspective, inefficient care is seen as the main problem. The second perspective, the social-political, concerns the relationship between the government and citizens. From this perspective, provider-oriented care is characterized by a central, protecting role 
of the government that provides rights and duties to citizens. As a result, increasing numbers of dependent citizens are signalled as well as increasing individualism and indifference with respect to other people. Finally, the institutional level concerns the relationship between professionals and clients. From this perspective, professional knowledge and professional standards are central. The central problem according to this perspective is that the provision of care is rigid because professionals stick to bureaucracy, protocols and procedures (Goudriaan \& Vaalburg, 1998).

A diagnosis-based orientation to care is positioned as the opposite of clientcentred care by several authors (Boeije, 1997; Pool \& Grypdonck, 1997). According to these authors, the emphasis in diagnosis-based nursing is on standardized care and professional scientific knowledge. The care demand is expressed as an actual or potential nursing diagnosis. Nursing theories such as Orem, Roy and Levine are associated with this view. The aim of care is functional repair and health, formulated as the possibility to function somatically and psychosocially. Nursing care aims at resolving the problems identified.

\section{Primary process}

The client demand is redefined by the professional as an objective need. Problems (objective needs), their signs and etiological factors are based upon scientific knowledge, organized within classification schemes. Care interventions are evidence-based, in order to increase the effectiveness of care. Objected outcomes of care aim at resolving or preventing the problem. A provider-oriented approach can be characterized as a one-sided process: the responsibility is with the professional. The professional takes decisions about the existing problems, outcomes objected and interventions needed. The client is expected to be a good patient and to comply with the decisions taken by the professional (Latvala, 2002, Verbeek, 1999). In a provider-oriented approach, proficiency is with the professional, who 'knows what is best for the client'.

\subsubsection{The most extreme form: demand-led care}

Demand-led care, also called demand-driven care or user-led care (see table 1) is seen as the most extreme form of client-centredness. Where a provider-oriented approach concerns a traditional, undesired situation, demand-led care is presented as an innovative, desired situation (Verbeek, 1999). Several different interpretations of the concept of demand-led care can be found in the literature, which can be reduced to three principle forms of steering: steering of the demand, steering towards the demand and steering by the demand (van der Kraan, 2001). Demand-led care in the primary process of care, can be explained as steering by the demand. The remaining forms of steering apply to a meso- or macro perspec- 
tive. The goals of demand-led care from a political-economical perspective concern more efficiency, optimalization of client-responsiveness, and optimalization of freedom of choice (Bosselaar et al., 2002). Introduction of a market mechanism is seen as the way to obtain these goals. This model is often associated with consumerism and marketisation of health care.

From an institutional perspective, demand-led care aims to roll back the professional role, and to increase client empowerment and the client demand as the starting point for care and reinforcement of the relationship between efforts and payment.

From a social-political perspective, the goals of demand-led care are client autonomy and client competency as a starting point for care and re-allocation of responsibilities to the client (Bosselaar et al., 2002).

From the client-perspective, demand-led care is defined as "directing supply by the demand, in which the client actually has the means to direct the supply" (Goudriaan \& Vaalburg, 1998, p. 132). Formerly, clients only received help 'in natura'. Today, a budget-system (PGB) has been developed where people with a disability, or their carers, are allocated a budget that they are free to use. In this way, two goals are targetted: clients have a greater say over their own situation, while organizations compete on quality and effectiveness (NIZW, 1999). This individual-budget system is seen as the ultimate means of guaranteeing client power to purchase. Demand-led care is associated with an optimal level of deregulation and decentralization.

Primary process of care

Demand-led care emphasizes the client's role as the director of care, and is based upon responsibility for care residing with the client. The client actively directs care and takes decisions about the care he or she wants. In this situation, it is the client who decides what services and products to buy, with whom and when. In this situation he also has the means and possibilities to do so. Demand-led care can be characterized as a one-sided process: the client is optimally involved in care. The power in the care relationship and the responsibility for care rests with the client. Decision making can be characterized as informed choice. Demand-led care assumes a competent client, able and ready to express what he wants and to make care decisions and having the opportunity to take decisions (van Haaster, 2001). The client is an expert towards the care needed, based upon his experience-based knowledge. In addition to being the director of care, the client is a buyer of services and products. 


\subsubsection{Demand-oriented care}

Demand-oriented care can be positioned in between the extremes discussed (see table 1).

It is a concept that is frequently used in the Netherlands. Demand-oriented care focuses mainly on the primary process of care (van Overbeek, 2002, Tonkens, 2003).

In the primary process of care it is described as:

"A collaborative effort of both the client and the professional, resulting in care that meets the client wishes and expectations and at the same time meets the professional standards" (RVZ, 1998, p.14).

This definition emphasizes client autonomy, but at the same time values the perspective of the professional. Furthermore, this definition emphasizes the professional-client collaboration, or in other words, the client participation in the care process. Besides collaboration, a characteristic of demand-oriented care is shared responsibility of the client and the professional. The client's subjective needs and expressed demands are central, but in dialogue decisions about the care demand and care are taken. (Goudriaan \& Vaalburg, 1998; Pool, Mostert, \& Schumacher, 2003, Verbeek, 2002). It can be characterized as a two-sided process. Decisions concerning care, priorities and outcomes are discussed in collaboration with the client, also if clients have impaired competencies (Boeije 1997, Hobson (1996), Verbeek (1999). The dialogue is optimal if client and professional are equal partners in care (Verbeek 1999).

A concept, close to demand-oriented care is the concept of emotion-oriented care (Grypdonck, 1996; NIZW, 2002; Pool et al., 2003; Schrijnemaekers, 2002; van der Kooij, 2003). Emotion-oriented care was introduced in the Netherlands in the 1990s. The concept is based upon a phenomenological perspective. This implies that human reality consists of the meaning given to it by an individual. According to this perspective, the starting point for care is the client's experience and the meaning given to the illness by the client. Central values are client autonomy, equality, agreement and appropriate care in accordance with professional values (Pool et al., 2003). Nurses try to understand the client as an autonomous individual, try to reduce the consequences of the illness and support the individual existence. The concept of emotion-oriented care is particularly applied in the context of the elderly and the chronically ill, having somatic or cognitive disabilities. 
Table 1. Client-centred concepts for the primary process of care and some characteristics

\begin{tabular}{|c|c|c|c|}
\hline & $\begin{array}{l}\text { Provider-oriented } \\
\text { approach }\end{array}$ & $\begin{array}{l}\text { Client-centred care: } \\
\text { Demand-oriented care }\end{array}$ & $\begin{array}{l}\text { Client-centred care: } \\
\text { Demand-led care }\end{array}$ \\
\hline Core perspective & $\begin{array}{l}\text { Professional } \\
\text { knowledge and } \\
\text { professional standards } \\
\text { are central }\end{array}$ & $\begin{array}{l}\text { Client is central and } \\
\text { professional standards are } \\
\text { central }\end{array}$ & Client is central \\
\hline Aim & $\begin{array}{l}\text { Functional repair } \\
\text { Health }\end{array}$ & $\begin{array}{l}\text { Giving assistance in } \\
\text { individual existence }\end{array}$ & Control \\
\hline Client autonomy & $\begin{array}{l}\text { Denial of client } \\
\text { autonomy }\end{array}$ & Client autonomy & $\begin{array}{l}\text { Free choice; } \\
\text { Consumerist attitude }\end{array}$ \\
\hline $\begin{array}{l}\text { Client } \\
\text { Participation }\end{array}$ & $\begin{array}{l}\text { Passive receiver of } \\
\text { care; Compliance } \\
\text { Nurse decision } \\
\text { making }\end{array}$ & Collaboration; Dialogue & $\begin{array}{l}\text { Active attitude } \\
\text { Client takes } \\
\text { responsibility and } \\
\text { decisions }\end{array}$ \\
\hline Care relationship & $\begin{array}{l}\text { Unilateral } \\
\text { relationship; Power } \\
\text { with nurse; }\end{array}$ & $\begin{array}{l}\text { Equality, bilateral } \\
\text { relationship }\end{array}$ & $\begin{array}{l}\text { Unilateral relationship; } \\
\text { Power with client }\end{array}$ \\
\hline Client demand & $\begin{array}{l}\text { Objective needs, } \\
\text { redefined by the } \\
\text { professional }\end{array}$ & $\begin{array}{l}\text { Subjective needs } \\
\text { and expressed demand }\end{array}$ & $\begin{array}{l}\text { Expressed demand } \\
\text { 'wants' }\end{array}$ \\
\hline Nursing theory & $\begin{array}{l}\text { Focus on nurse's } \\
\text { perspective (Orem, } \\
\text { Roy, Levine) }\end{array}$ & $\begin{array}{l}\text { Focus on nature of } \\
\text { relationship } \\
\text { Interaction models } \\
\text { New paradigm theories }\end{array}$ & $\begin{array}{l}\text { Focus on nature of } \\
\text { relationship } \\
\text { Interaction models } \\
\text { New paradigm } \\
\text { theories }\end{array}$ \\
\hline Client-centredness & $\begin{array}{l}\leftarrow \text { Care is not client- } \\
\text { centred }\end{array}$ & $\begin{array}{l}\leftarrow \text { Various degrees } \rightarrow \\
\text { of client-centred care }\end{array}$ & $\begin{array}{l}\text { Most extreme form } \rightarrow \\
\text { of client-centred care }\end{array}$ \\
\hline
\end{tabular}

\subsubsection{Roots of client-centred care}

Since about the 1980s, in the Netherlands, a wholesale change can be obserbved in perspectives on care. This is partly connected to individualization in society and increased self-assertiveness among clients. These developments contributed to the introduction of client-centred concepts of care. Clients have become more critical and ask for care that meets their individual wishes and demands. Instead of the professional, and organizational rules and regulations directing care, clients want a greater say in their own care process (Goudriaan \& Vaalburg, 1998; Philipsen, 1997; Pool, Pool-Tromp, Veltman-van Vugt, \& Vogel, 2001; Stüssgen, 1997). Client autonomy can be seen as the core of the client perspective 
(NCCZ, 1999). In the 1990s, patient autonomy began to acquire increasing importance in health care policies regarding chronically ill people (ter Meulen 1994). Client autonomy is supported by the Dutch law, such as the Medical Treatment Agreement Law. Verbeek (1999) points to sociology and philosophy (Zola and Illich) as being at the onset of this paradigm shift in health care. Zola (1973) introduced the concept of 'medicalization'. In his view, medicine increasingly dominates common life, and judges life in the name of health. Illich (1975) held that professional care contributes to dependency, dispenses with independence and individuality, and limits individual competencies. The critics of Zola and Illich are addressed at a large group of clients and professionals. Tonkens (2003), a Dutch present-day critic in health care, characterizes the increasing emphasis on client-centred care as a twofold crisis within the 'welfare state' with respect to bureaucracy on the one hand and professionalism on the other. It is no longer clear that professionals can make better decisions than clients can make for themselves. Bureaucracy is judged as inappropriate and inefficient, and even counter-productive, because it encourages passive, dependent behaviour instead of an independent, active attitude towards care. Policy aimed at empowerment of clients and at mobilizing market forces, has been introduced as substitutes for professionalism and for bureaucracy (Tonkens, 2003).

Care that optimally fits the needs and demands of the individual client can be positioned in a tradition of nursing and nursing sciences, mainly inspired by Benner \& Wrubel, 1989; King, 1981; Koene, Grypdonck, Rodenbach, \& Windey, 1982; Patterson \& Zderad, 1976 and Watson, 1988. According to McCormack (2004), client-centredness is a principle that is implicit in many models of nursing with a humanistic philosophical underpinning. In addition, the work of Rogers (1961) and his articulation of 'the helping relationship' is seen to transcend all these models. Stevens-Barnum (1998) has identified a shift over time in the nursing viewpoint with respect to nurse-client interaction. She distinguishes new paradigm theories from traditional theories. Where the traditional theories place the emphasis on the nursing act mainly in acute care, where it is intended to transform an undesirable patient situation into a desirable one (goal), in the new paradigm theories the client (in a more diverse context) retains control. Theories in the new paradigm see the client as the main agent, and the nurse as his or her helper. These newer theories (e.g. Quinn, 1992; Watson, 1988) focus on the client and on the interaction. The agent of change is viewed as the individual patient, but the nurse can be a co-participant in change through the human care process. Former interaction models focus on a communication model that is based on interpersonal communication. According to Stevens-Barnum (1998) examples of these theories are those of Orlando (1961), King (1961), and Peplau (1952). In more recent interaction models the notion of communication has expanded to encompass more than verbal communication (Stevens-Barnum, 1998). 


\subsection{CHRONICALLY ILL PEOPLE RECEIVING LONG-TERM CARE}

In the Netherlands, there is no universal definition of chronic illness. A few common characteristics, however, can be mentioned (Ruwaard, van den Berg Jeths, \& Gijsen, 1999). Firstly, chronic illnesses encompass somatic, psychological and social disorders existing over longer time. Secondly, chronic diseases are irreversible; that is medical science cannot effectively cure, nor repair the damage caused by the disease. There is no perspective of complete recovery. Thirdly, chronic diseases are instable and vary in their impact. Some diseases may be temporarily stabilized by the use of medication, while others are attended by permanent disabilities (Ruwaard, 1997; Spaink, 1997). Estimations concerning the number of chronically ill people are difficult due to several reasons, to begin with differences in definitions. Furthermore, overviews based upon care registrations differ considerably from overviews based upon epidemiological population-based studies (Ruwaard et al., 1999). Finally, estimations are difficult, because chronic illnesses are frequently accompanied with co-morbidity. Ruwaard et al. (1999) selected chronic illnesses with a high prevalence or incidence that contributed considerably to mortality rates and costs in health care. Based upon care registrations it is estimated that in 1994 there were 3.2 million cases of the selected chronic illnesses in the Netherlands. This percentage is expected to grow. What is striking is the increasing share of people older than 45 years, especially men, due partly to the aging of the post-war birth bulge, and partly to the expected decrease in mortality. An increase of the number of chronically ill of $25 \%-40 \%$ is predicted for 2010 by the National Institute for Public Health and the Environment (RIVM, 1993). As a result, many people with a chronic disease will need health care in the future. By then, the care needed will be even more complex than it is now. Singular treatment and interventions are in most situations not sufficient. Several professional disciplines will be involved in a multidisciplinary approach of long-term care (Ruwaard, 1997; RVZ, 2000). People with a chronic illness may experience various long-term problems because of the disorder, the loss of bodily structures or changes in somatic or psychological functions, problems with activities of daily living, and problems in performing societal roles (Pool et al., 2003). Many of them are dependent on professional care for a longer time, and many for the rest of their lives. A chronic illness may affect a person's total existence and the situation of his or her family is at stake. Chronically ill people are confronted with the irreversible deterioration of their health situation and its impact on all aspects of life. Philipsen (1997) distinguishes between health problems and care or dependency problems. It is argued that the latter are more complex. Pool et al. (2003) describe the efforts of chronically ill people in finding a balance between requirements of the treatment on the 
one hand and the exigencies of life on the other. They distinguish illness-related, personal, social, and material problems and tasks. Bellemakers and van Houten (1996) emphasize the frequently capricious nature of a chronic illness, resulting in a changing care demand. This is difficult to explain to others and often raises many difficulties. Another element of a chronic illness that causes problems is the invisibility of many diseases and impairments to others. Furthermore, even in the case of the same disease, there is a wide variety in the disabilities in daily functioning and care dependency experienced.

People with a chronic illness are frequently obliged to appeal to professional care. Professional care is inherent to dependence, and always entails a threat to client autonomy (Tronto, 1994). Bellemakers and van Houten (1996) state that people with a chronic illness are structurally dependent upon professional care. Sometimes "almost the entire life is shared with other people". In their opinion, being chronically dependent demands a very active attitude on the part of the client. This role, however, frequently conflicts with the traditional role assigned to clients with a chronic disease.

\subsection{HOME NURSING CARE}

People with a chronic illness are seen in all health care settings. A hospital stay is sometimes necessary for diagnostic or treatment purposes. There has been an increase, however, of interventions in the home situation, partly because government policy is focused on home care rather than institutional (residential and hospital) care. Particularly in home care services for chronically ill clients, clientcentred care is an important issue.

In general, Dutch home care includes help and support for ill, disabled, frail and/or older people in their own homes or the homes of relatives (Walker, 1998). Home care is provided by professional caregivers, informal caregivers (such as relatives or neighbours) or volunteers. Professional care is mainly delivered by professional home care organizations.

Home care organizations can be described as service-oriented care systems, covering home help services and home nursing and caring. Home help services concern help with daily tasks at home such as housekeeping activities. The emphasis of home nursing and caring is on nursing of ill people at home by rehabilitative, supportive, promotive or preventive and technical nursing care. In 1998, about 4\% of the total Dutch population (almost 580,000 people) received professional home care. About 130,000 people, most of them on a part-time basis, worked in home care services in 1997 (van der Windt, Calsbeek, \& Hingstman, 1999). The scope of professional care needed is influenced by both social and political developments. Social developments in this respect include the decrease in informal care related to smaller families, more women with a job, an increasing 
number of elderly single people, and changing attitudes towards lifestyle, family relations and privacy. Political developments which influence professional care needed concern efficiency and cost-containment measures. Attempts have been made to introduce market strategies with respect to insurers of care, and the introduction of the personal-budget in health care to improve flexibility and efficiency in the provision of services. With a so called 'personal budget', for example, clients themselves are able to buy the care they need and choose their own care provider. As a result, home care organizations are under increasing pressure to work harder and more efficiently than in the past, and at the same time to provide client-centred care. The transition of the Dutch home care system from a serviceoriented system into a more client-centred system is an important challenge.

\subsection{NURSE'S COMPETENCIES AND DEVELOPMENT OF COMPETENCIES}

At present, there is a lot of attention for competencies, development of competencies and management of competencies. This can be seen as an answer to societal developments emphasizing adequate performance in a complex and changing practice. A lot of confusion exists concerning the concept of 'competency'. A 'competency' is defined by Onstenk (1997) as the ability to use a set of knowledge, attitudes and skills, in order to perform concrete activities in an adequate way, and in the same time deal with tasks, problems, dilemmas and contradictions confronted with in the practice situation. In line with this definition, a competency is defined by Pool et al. (2001) as "the ability and the motivation of a person to perform effective behaviour in the context of practice" (Pool et al., 2001, p. 52).

Nurses and auxiliary nurses giving home care differ in the competencies they acquired during their basic training. In the current system of Dutch education for the caring and nursing professions, several levels of nursing and caring are defined, including two levels of nursing. Nurses and carers who currently work with chronically ill people are educated as registered (community) nurses Bachelor's degree (level 5), registered nurses (level 4), and auxiliary nurses, not registered as nurses, (level 3 and 3 IG) (OCW \& VWS, 1997). Nursing and caring for the chronically ill is defined at all levels. Definitions of care emphasize the maintenance and promotion of self-care of the client, while definitions of nursing focus on the nursing process, coordination of care, quality of care and development of expert knowledge of the nurse. The competencies of nurses with a Bachelor's degree were made explicit in a project 'Professional competencies of nurses with a Bachelor's degree' (Pool et al., 2001). In this project, the aim of nursing care for chronically ill people is described as assisting and guiding people with a chronic illness in dealing with the consequences of their illness on their daily lives, so that 
people maintain their autonomy as long as possible (Grypdonck, 1996; Pool, 2002; Pool et al., 2001). According to Grypdonck (1996), nurses can offer help in four ways: firstly, by giving support in coping with being chronically ill; secondly, by facilitating the struggle of daily life; thirdly, by helping with the application of the therapeutic regime; and finally by assisting with care management. Care aims at reinforcing the self-management and autonomy of the chronically ill.

Several reports point to the need for development of competencies in professionals with respect to client-centred care (HGZO, 2000; RVZ, 2000). Development of competencies is a didactical approach, grounded in a trend called social-constructivism. It offers possibilities to meet the changing requirements imposed on nurses. According to this approach, learning emphasizes socialpsychological elements of learning rather than cognitive elements. The emphasis is on the student, his learning processes, the learning environment, integration and performance in practice. Development of competencies is characterized by a close relationship with the context of practice, demand-led learning processes, the teacher as a coach of learning processes and assessment of competencies in practice (Auer, 1994; Bolhuis, 2001; Dochy, Heylen, \& van de Mosselaer, 2002). What client-centred care in the context of the primary process of home care for chronically ill clients encompasses, however, is not clear. Confusion exists among professionals about the meaning and application of the different concepts related to client-centred care, at the expense of a successful introduction in practice (Little et al.2001, Rijckmans et al., 2002; Mead \&Bower, 2002b; van der Kraan, 2001). Many publications in literature and policy notes are available concerning client-centred care, and related concepts, but the actual competencies required for nursing practice are not clear. What is the client's perspective and what is the nurse's perspective on client-centred care, and competencies required in nurses? How can an internally and externally consistent learning programme aimed at devlopment of competencies in nurses with respect to client-centred care be developed? How can we evaluate development of competencies and the impact of the learning programme?

The present research project aims at examining these questions.

\subsection{CONTEXT OF THE STUDY}

At the explicit request of client organizations, a learning programme aimed at promoting nurses' competencies for client-centred care was developed, implemented and evaluated in three home care organizations. This thesis reports on a research project closely related to the development, execution and evaluation of this learning programme (see figure 1).

Part I of this thesis, exploring and describing the perspectives on client-centred care, provided input for the development of the programme in Part II. The 


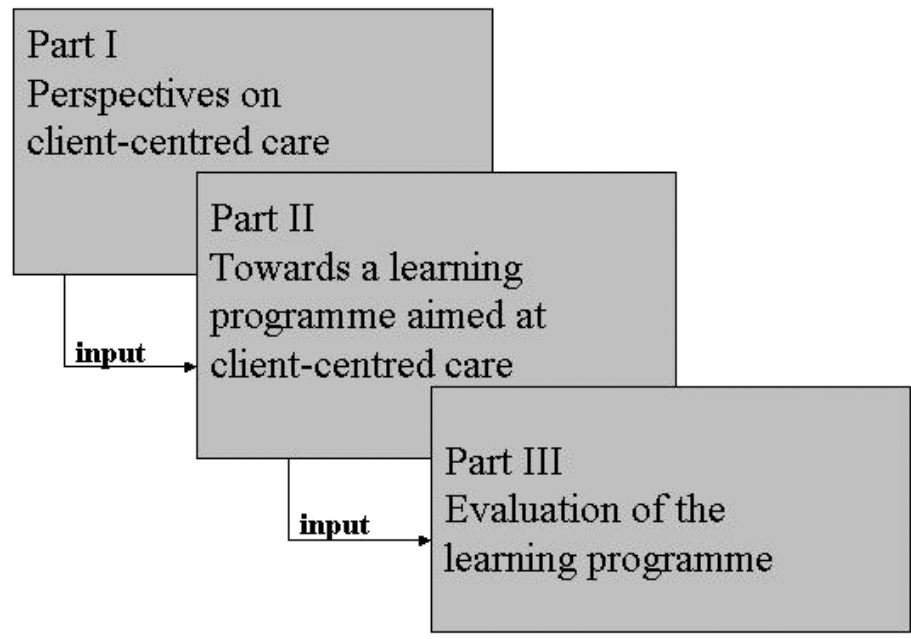

Figure 1. Relationship between the research project and the learning programme

process of programme development based upon the identification of client goals and nurse competencies is described in Part II. The client goals and nurse competencies identified in this part provided input for the development of the evaluation criteria defined in Part III. Part III concerns the further development and testing of the measurement instruments and evaluation of the learning programme.

The team developing the learning programme (Part II) consisted of six experts with knowledge of the central theme: representing a centre for secondary professional education, the Chronisch Zieken en Gehandicaptenraad (CG-Raad) [the Dutch Council for the Chronically Ill and the Disabled], the Kenniscentrum voor Revalidatie en Handicap (iRv) [Institute for Rehabilitation Research], and two universities for professional education. Two of the members of the development team were also researchers involved in the present research study. The content of the learning programme was developed in close collaboration with a steering committee and with an advisory board. The steering committee consisted of nurses, managers and members of the client council of three home care organizations and members of two provincial patient organizations (Patienten Consumenten Limburg) [Patient Consumers Limburg] and Federatie Gehandicaptenorganisaties Limburg [Limburg Federation of Organizations for the Handicapped]). The advisory group consisted of several coordinating national organizations for clients, nurses and nurses' assistants. The Chronisch Zieken en Gehandicaptenraad (CG- Raad), Landelijk Expertisecentrum voor 
Verpleging en Verzorging (LEVV) [the National Expertise Centre for Nursing and Caring], Landelijke Vereninging voor Wijkverpleging (STING) [National Association for Community Nursing], Landelijke Organisatie voor Thuisverzorgers [National Organization for Home Carers], Koepelorganisatie voor Regionale Opleidings Centra (BVE-Raad) [Coordinating Organzation for Regional Education Centers], and the Nederlandse Vereniging voor Ziekenhuizen [Dutch Association of Hospitals].

The development, implementation and evaluation of the learning programme was financed with support of ZonMw [the Netherland Organisation for Health Research and Development], Centraal Fonds RVVZ [Health Insurance Foundation], and the three educational institutions involved (Arcus College, Fontys Hogescholen and Hogeschool Zuyd). The home care organizations involved in the studies are Thuiszorg midden-limburg, Groene Kruis Zorg, ZuidZorg (until 1-1-2005 called Thuiszorg Kempenstreek), and Thuiszorg Oostelijk ZuidLimburg.

\subsection{METHODOLOGICAL CONSIDERATIONS}

The studies discussed consisted of a mixture of qualitative and quantitative research methods, guided by the nature of the respective research questions. Qualitative and quantitative research methods can be viewed as complementary (Pope \& Mays, 1995). It is expected that the combination of qualitative and quantitative methods and the use of different methods for data-collection will strengthen the design (Pope \& Mays, 1995). The emphasis, however, is on a qualitative research method, particularly the grounded theory approach (Strauss \& Corbin, 1998), in order to explore the perspectives of the clients and of the nurses towards client-centred care. This approach was chosen because little was known about the phenomena under study and because this approach provides strategies for developing concepts and theories that fit into the particular field of practice. This may contribute to the use of final recommendations of the study by the professionals. Important procedures in the grounded theory approach are constant comparison and theoretical sampling. Several techniques for data collection were chosen to explore the perspectives of clients and nurses towards clientcentred care: focus interviews, participatory observations and semi-structured interviews. The focus interviews were held with expert clients and family caregivers, allied to the Dutch Council of the Chronically Ill and the Disabled. Additionally, a study was performed to explore interaction with respect to clientcentred care from the perspective of clients receiving home care. In this study, participatory observations and semi-structured interviews with clients of three home care organizations were held. The nurses' perception towards client- 
centred care was investigated by means of participatory observations and semistructured interviews with nurses of three home care organizations.

The development of the learning programme, including its evaluation criteria was guided by a conceptual framework on curriculum consistency: the Kessels eight-fields model (Kessels \& Plomp, 1999). This model was chosen because of its attention for external and internal validity. The findings of the qualitative studies concerning the clients' and nurses' perspectives towards client-centred care provided the input during the development phase of the learning programme. Client goals and nurses' competencies for client-centred care, formulated during the development process of the programme, were operationalized respectively into an instrument to evaluate experienced client-centredness by clients, and a self-assessment scale to evaluate performance of competencies by nurses. A combination of qualitative and quantitative methods were used to evaluate the programme at three levels: evaluation of experienced client-centredness by clients, evaluation of performance of competencies by nurses, and a process evaluation. This study was performed with employees and clients of three home-care organizations. The client instrument was additionally tested with clients of three home care organizations. The nurse iinstrument was additionally tested with nurses of four home-care organizations.

The study was performed between 2002 and 2005.

\subsection{OUTLINES OF THE THESIS}

An overview of the sub-questions derived from the central research questions presented in section 1 , the methods used and the corresponding chapter of the thesis are presented in Table 2 .

Table 2. Research questions and methods contained in the thesis

$\begin{array}{lll}\text { Theme } & \text { Method } & \text { Chapter } \\ \text { The client perspective (expert clients) } & \text { Qualitative study } & 2 \\ \text { The client perspective } & \text { Qualitative study } & 3 \\ \text { The nurses' perspective } & \text { Qualitative study } & 4 \\ \begin{array}{l}\text { Defining client goals, nurses' competencies and } \\ \text { development of the learning programme }\end{array} & \begin{array}{l}\text { Application of Kessels's 'eight-field } \\ \text { model' }\end{array} & 5 \\ \begin{array}{l}\text { Scale development and testing: nurse's } \\ \text { competencies }\end{array} & \text { Quantitative study } \\ \begin{array}{l}\text { Scale development and testing: client- } \\ \text { centredness perceived by clients }\end{array} & 6 \\ \begin{array}{l}\text { Evaluation study of the learning programme } \\ \text { Quantitative study }\end{array} & 7\end{array}$


Part I of this thesis concerns different perspectives on client-centred care (chapters $2-4)$. Chapter 2 is devoted to the perspectives of the expert clients with a chronic illness and family caregivers. What do they think of the interaction with nurses and nurses' aids aimed at tailoring care to their demand? And what competencies are required for nurses? Chapter 3 presents a study into the interaction between clients and nurses with respect to client-centred care from the perspective of clients. Chapter 4 describes the exploration of the nurses' perception towards client-centred care. How do nurses and auxiliary nurses perceive client-centred care? How do nurses deal with tensions perceived?

Part II (Chapter 5) concerns the process and result of defining the core competencies for nurses with respect to client-centred care. The definition of these competencies was used as the basis for developing and evaluating the learning programme aimed at competence development in nurses.

Part III (Chapters 6-8) concerns the evaluation of the programme. In chapter 6 the development and testing of a self-assessment scale for nurses is presented. How can professional competencies be assessed in a reliable and valid way? Chapter 7 describes the development and testing of an instrument aimed at evaluating the client-centred care as perceived by clients. Chapter 8 concerns the evaluation of the learning programme at three levels: a process evaluation, performance of competencies by nurses in practice, and client-centredness perceived by clients. In chapter 9 , the main results of the project are discussed, by summarizing the findings, by a theoretical reflection on the separate parts of this thesis and by a discussion of the contributions of the study in the context of ethics. Furthermore, the methodological strengths and limitations of the project as well implications of the study are elaborated.

A summary of the content of this thesis starts on page 207.

This thesis is compiled on the basis of articles, which have been published or submitted separately. This is the reason for some overlap in description of literature, methods and results. Two of the articles (chapters 5,6) have been published by Dutch journals. Both articles are inserted in this thesis in the original format. 


\section{REFERENCES}

Auer, C. (Ed.). (1994). Opleiders in Organisaties, Capita Selecta (Teachers in Organizations: Capita Selecta, (Vol 20). Deventer: Kluwer Bedrijfswetenschappen.

Bellemakers, C., \& van Houten, D. (1996). Het leven en de zorgen van mensen met een chronische ziekte (Life and concerns of people with a chronical illness). Praktische Humanistiek, 6(2), 12-24.

Benner, P., \& Wrubel, J. (1989). The primacy of caring. Stress and coping in health and illness. Menlo Park: Addison-Wesley Publishing Company.

Boeije, H. R. e. a. (1997). Een verzorgde toekomst. Toekomstscenario's voor verpleging en verzorging. (A well cared-for future. Future scenarios for nursing and caring).Utrecht: De Tijdstroom.

Bolhuis, S. (2001). Leren en veranderen bij volwassenen (Learning and Changing in adults). Tweede herziene druk.Bussum: Coutinho.

Bosselaar, H., van der Wolk, J., Zwart, K., \& Spies, H. (Eds.). (2002). Vraagsturing: De client aan het roer in de sociale zekerheid en zorg (Steering by the demand. The client at the helm) (Vol. 23).

Cahill, J. (1998). Patient participation: A review of the literature. Journal of Clinical Nursing, 7, $119-128$.

Chewning, B., \& Sleath, B. (1996). Medication decision-making and management: A clientcentred model. Social Science and Medicine, 42, 389-398.

Dochy, F., Heylen, L., \& Van de Mosselaer, H. (2002). Assessment in het onderwijs: nieuwe toetsvormen en examinering in studentgericht onderwijs en competentiegericht onderwijs (Assessment in education: new methods for testing and assessment in student-centred and competence-based education). Utrecht: Lemma

Donaldson, L. M. (2001). The Expert Patient: A New Approach to Chronic Disease management for the 21st century. London: Department of Health.

Elwyn, G. (2001). Shared decision making: Patient involvement in clinical practice, Dissertation. Nijmegen: Katholieke Universiteit Nijmegen.

Emmanuel, J., \& Emmanuel, L. (1992). Four Models of the Physician-Patient Relationship. JAMA, 267(16), 2221-2226.

Gage, M., \& Polatajko, H. (1995). Naming practice: The case for the term client-driven. Canadian Journal of Occupatinal Therapy, 62, 115-118.

Goudriaan, G., \& Vaalburg, A. M. (1998). De vraag als maat (Using demand as a yardstick). Utrecht: Nederlandse Patienten/Consumentenfederatie (NP/CF) and Nederlands Instituut voor Zorg en Welzijn (NIZW).

Grol, R., de Maeseneer, J., Whitfield, M., \& Mokkink, H. (1990). Disease-centred versus patient-centred attitudes: comparison of general practitioners in Belgium, Britain and the Netherlands. Family Practice, 7(100).

Grypdonck, M. H. F. (1996). Het leven boven de ziekte nittillen. De opdracht van de verpleegkunde en de verplegingswetenschap voor chronisch zieken. (Raising life over illness. The task of nursing and nursing science with respect to the chronically ill). Leiden: Spruyt, van Mantgem en de Does.

HGZO. (2000). De Toekomst van het hoger gezondheidszorg onderwijs (The future of advanced health care education). Eindrapport van de verkenningscommissie HGZO. 
Hobson, R. (1996). Being client-centred when the client is cognitively impaired. Canadian Journal of Occupational Therapy, 63, 133-137.

Illich, I. (1975). Het medische bedriff-een bedreiging voor de gezondheidszorg (The medical business- a threat for health care). Baarn: Het wereldvenster.

Kessels, J., \& Plomp, G. (1999). A systematic and relational approach to obtaining curriculum consistency in corporate education. Journal of Curriculum Studies, 31(6), 679-709.

King, I. (1981). A theory for nursing. Systems, concepts, process. New York: John Wiley.

KITTZ. (2004). Sprong naar Vraaggericht denken en handelen. (Spring towards demand-oriented thinking and acting) Groningen.

Koene, G. B. M. L., Grypdonck, M., Rodenbach, M., \& Windey, T. (1982). Integrerende verpleegkunde. Wetenschap in praktijk (Integral nursing. Science and practice) Lochum: De Tijdstroom.

Latvala, E. (2002). Developing and testing methods for improving patient-oriented mental health care. Journal of Psychiatric and Mental Health Nursing, 9, 41-47.

Lewin, S. A., Skea, Z. C., Entwistle, V., Zwarenstein, M., \& Dick, J. (2001). Interventions for providers to promote a patient-centred approach in clinical consultations. Cochrane Review.

Little, P., Everitt, H., Williamson, I., Warner, G., Moore, M., Gould, C., et al. (2001). Preferences of patients for patient centred approach to consultation in primary care: oberservational study. British Medical Journal, 322, 468-472.

McCormack, B. (2004). Person-centredness in gerontological nursing: an overview of the literature. Journal of Clinical Nursing, 13(3a), 31-38.

McWhinney, I. R. (1995). Why we need a new clinical method. In M. Stewart, J. B. Brown, W. W. Weston, I. R. McWhinney, C. L. McWilliam \& T. R. Freeman (Eds.), Patientcentred medicine: Transforming the clinical method. Thousand Oaks: Sage.

Mead, N., \& Bower, P. (2000a). Measuring patient-centredness: a comparison of three observation-based instruments. Patient Education and Counseling, 39, 71-80.

Mead, N., \& Bower, P. (2000b). Patient-centredness: a conceptual framework and review of the empirical literature. Social Science and Medicine, 51, 1087-1110.

Ministerie VWS. Zicht op zorg. Care within sight. The Hague, Ministerie VWS.

Nationale commissie Chronisch Zieken (NCCZ). (1999). Chronisch-ziekenbeleid in de jaren negentig. Policy on the chronically ill in the 1990s. Utrecht: Uitgeverij SWP.

NIZW. (1999). Who cares? Utrecht: NIZW.

NIZW. (2002). Belevingsgerichte hulpverlening in de thuiszorgpraktijk. (Emotion-oriented care in home care) Utrecht: NIZW.

OCW, \& VWS. (1997). Gekwalificeerd voor de toekomst. Kwalificatiestructuur en Eindtermen voor de verpleging en verzorging. (Qualified for the future. Qualification criteria for nursing and caring) Zoetermeer/Rijswijk.

Onstenk, J. (1997). Lerend leren werken. Brede vakbekwaamheid en integratie van leren, werken en innoveren (Learning while learning to work. Broad competencies and integration of learning, working, and innovation. Delft: Eburon.

Orlando, I. J. (1961). The Dynamic Nurse-Patient Relationship. New York: NY: Putnam. 
Patterson, J. G., \& Zderad, L. T. (1976). Humanistic nursing. New York: Willey.

Peplau, H. E. (1952). Interpersonal Relations in Nursing. New York: NY:Putnam

Philipsen, H. (1997). Vraaggestuurde zorg: Het belang van professionele fundering van de 'erkende vraag' naar zorg. (Demand-led care: The importance of professional foundation of the ' recognized care demand' ) In L. Boon (Ed.), Vraaggestuurde Zorg. Amstelveen: Sympoz.

Pool, A. (2002). Verpleegkundige professionaliteit bij vraaggerichte zorg (Nursing proficiency in demand-oriented care). In L. Boon (Ed.), Vraaggestuurde zorg. Amstelveen: Sympoz.

Pool, A., \& Grypdonck, M. (1997). Diagnosegestuurd of behoeftegestuurd? Twee orientaties in de verpleegkunde (Diagnosis-oriented or demand-oriented. Tijdschrift voor Verpleegkundige, 107(10), 292-295.

Pool, A., Mostert, H., \& Schumacher, J. (2003). De kunst van het afstemmen (The art of finetuning). Utrecht: NIZW.

Pool, A., Pool-Tromp, C., Veltman-van Vugt, F., \& Vogel, S. (2001). Met het oog op de toekomst. Beroepscompetenties van HBO-Verpleegkundigen (With a view to the future. Professional Competencies for nurses with a Bachelors degree) Utrecht: NIZW.

Pope, C., \& Mays, N. (1995). Reaching the parts other methods cannot reach:an introduction to qualitative methods in health and health services research. BMJ, 311, 42-45.

Quinn, J. F. (1992). Holding sacred space: The nurse as healing environment. Holistic Nursing Practice, 4, 26-36.

Rijckmans, M. J. M., Garretsen, H. F. I., Bongers, I. M. B., \& van de Goor, L. A. M. (2002). Vraaggerichtheid en vraagsturing. Een poging tot conceptuele verheldering (Demandoriented and demand-driven care. An attempt at conceptual transparency). Tijdschrift voor Sociale Gezondheidszorg, 80, 388-392.

RIVM. (1993). Rijksinstituut, voor Volksgezondheid en Milieuhygiene. Volksgezondheid Toekomst Verkenningen: de Gezondheidstoestand van de Nederlandse bevolking in de periode 1950-2010 (Public health Future Reconnoitrings. The Health situation of the Dutch people between 1950-2010). Den Haag: SDU Uitgeverij.

Rogers, C. (1961). On Becoming a Person. Boston: Houghton Mifflin Co.

Roter, D. L. (1989). Which facets of communication have strong effects on outcome: a metaanalysis. In M. Stewart (Ed.), Communication with medical patients.

Ruwaard, D., \& Kramers, P. G. N. (1997). Volksgezondheid toekomst verkenning 1997: de som der delen (Public Health Status and Forecasts 1997: the Sum of the Parts). Bilthoven: Elsevier/ De Tijdstroom.

Ruwaard, D., van den Berg Jeths, A., \& Gijsen, R. (1999). Demografie van chronisch ziek Nederland. In G. A. M. van den Bos, B. W. Frijling, Y. Koster-Dreese, P. Schnabel \& C. Spreeuwenberg (Eds.), Chronisch-ziekenbeleid in de jaren negentig (Health care policy for the chronically ill in the nineties). Utrecht: Uitgeverij SWP.

RVZ. (1998). Naar een meer vraaggerichte zorg (Towards increased demand-orientedness). Zoetermeer: Raad voor de Volksgezondheid. 
RVZ. (2000). Professionals in de gezondheidszorg (Professionals in health care). Zoetermeer: Raad voor de Volksgezonheid en Zorg.

Schrijnemaekers, V. J. J. (2002). Effects of emotion-oriented care in homes for the elderly, Thesis. Maastricht University, Maastricht.

SFS. (1982). The health and Medical Services Act. Stockholm: Social Ministry.

Spaink, K. (1997). The chronically ill: There are no such people. Paper presented at the 2nd European Nursing Congress, Empowerment of the chronically ill: A challenge for nursing.

Stevens-Barnum, B. S. (1998). Nursing theory: analysis, application, evaluation. New York: Lippincott.

Stewart, M. (2001). Towards a global definition of patient centred care. British Medical Journal(322), 444-445.

Strauss, A. L., \& Corbin, J. (1998). Basics of Qualitative Research. Techniques and Procedures for Developing Grounded Theory. Thousand Oaks: Sage Publications.

Stüssgen, R. A. J. (1997). Kwaliteit van verpleging/verzorging vanuit patiëntenperspectief(Quality of nursing/caring from a patient perspective). Utrecht: Nederlandse Patienten/Consumenten Federatie (NP/CF).

Ter Meulen, R. H. (1994). Verschraalde Zorg? over autonomie, identiteit, en zingeving in de zorg voor hulpbehoevende ouderen. Oratie. (Decreased care? About autonomy, identity and giving meaning in the care for dependent elderly. Inaugural lecture). Vugt: Radboudstichting.

Terpstra, E. (1997). Beleidsmatige dilemma's bij de vormgeving van vraaggestuurde zorg (Dilemmas in policy with respect to realizing demand-led care). In L. Boon (Ed.), Vraaggestuurde zorg. Amstelveen: Sympoz.

Tonkens, E. (2003). Mondige burgers, getemde professionals. Marktwerking, vraagsturing en professionaliteit in de publieke sector (Empowered citizens and tamed professionals: the market, demand-driven care and professionalism in the public sector). Utrecht: NIZW.

Tronto, J. C. (1994). Moral boundaries: a political argument for an ethic of care. New York: Routledge.

Van der Kooij, C. H. (2003). Gewoon lief zijn? Het maieutisch zorgconcept en het invoeren van geintegreerde belevingsgerichte zorg op psychogeriatrische zorgafdelingen (Just being nice? The maieutic care concept and the implementation of emotion-oriented careon psychogeriatric wards) . Vrije Universiteit Amsterdam, Amsterdam.

Van der Kraan, W. G. M. (2001). Vraaggericht en vraaggestuurd: Een literatuuronderzoek naar vraaggerichtheid en vraagsturing in de gezondheidszorg (Demand-oriented and demand-driven. A review of the literature into demand-oriented and demand-driven care in the health-care sector). The Hague: ZONMw en Erasmus Universiteit Rotterdam.

Van der Windt, W., Calsbeek, H., \& Hingstman, L. (1999). Verpleging en verzorging in kaart gebracht (Nursing and caring documented). Maarrssen/Utrecht: Elsevier/De Tijdstroomen LCVV.

Van Haaster, H. P. M. (2001). Cliëntenparticipatie (Client participation). Bussum: Coutinho.

Van Overbeek, R. (2002). Vraagverheldering in relatie tot vraaggerichte en vraaggestuurde zorg. Utrecht: NIZW. 
Verbeek, G. (1999). Zorg in samenspel. Samenwerking tussen cliënten en hun zorgverleners in vraaggerichte en vraaggestuurde zorg. (Interplay in care. Collaboration between clients and their caregivers in demand-oriented and demand-led care). . Utrecht: NIZW.

Verbeek, G. (2002). Samenspel en spanning tussen zorgverlener en gebruiker (Interplay and tensions between caregiver and care user). In L. Boon (Ed.), Vraaggestuurde zorg. Amstelveen: Sympoz.

Verbeek, G., \& Tiemersma, K. (1998). Aan elkaar gewaagd? Orientatie op het samenspel tussen cliënt en zorgverlener in een vraaggerichte zorg (A question of matching: Focusing on the interplay between clients and caregivers in demand-oriented care). Utrecht: NIZW.

Verkooijen, H. E. C., Elderhuis, R. M., Hamers, J. P. H., \& Spreeuwenberg, C. (2003). Vraaggestuurde zorg en het patiëntenperspectief. Een literatuurstudie. (Demand-led care and the patients' perspective. A literature study) Verpleegkunde, 18(1), 39-47.

VWS. (2000). Gezondheidszorgberoepen in beweging (Health care professions on the move): Ministerie van Volksgezondheid, Welzijn en Sport (VWS).

Walker, A. (Ed.). (1998). European home and community care 1998/99. The official EACH Reference Book. London: Campden Publishing Limited.

Watson, J. (1988). Nursing: Human science and human care. A theory of nursing. New York: National League for Nursing.

WHO. (1996). European Health Care Reforms. Citizens' Choice and Patients' Rights. Copenhagen: World Health Organization Regional Office fo Europe.

Zola, I. K. (1973). De medische macht. De invloed van de gezondheidszorg op de maatschappij (The power of medicine. The influence of health care on society). Meppel: Boom 

Part I

PERSPECTIVES ON CLIENT-CENTRED CARE 



\section{RECOGNITION OF CLIENT VALUES AS A BASIS FOR TAILORED CARE:}

the view of Dutch expert patients and family caregivers

Published as:

Schoot, T., Proot, I., ter Meulen, R., \& de Witte, L. (2005).

Recognition of client values as a basis for tailored care: the view of Dutch expert patients and family caregivers.

Scandinavian Journal of Caring Sciences, 19, 169-176 


\section{ABSTRACT}

In the Netherlands confusion is signaled about the introduction of new care concepts like demand-oriented care. The aim of this article is to explore the phenomenon 'interaction aimed at care tailored to the client demand' as seen by expert clients: patients and their family caregivers. Focus interviews were held with expert patients and expert family caregivers of the 'Dutch Council of the Chronically ill and the Disabled'. Grounded theory methodology was used to analyze the results.

Recognition by the professional of client values underlying their demand (uniqueness, comprehensiveness, continuity of life, fairness and autonomy) and underlying the care-relationship (equality, partnership, and interdependence) emerged as central element within the interaction. Feelings of recognition with the client seem to reinforce autonomy, self-esteem and participation. Recognition was optimally felt in a dialogue. Four professional competencies could be identified related to recognition: attentiveness (ongoing actions to know and understand the patient); responsiveness (active, committed and responsible care guided by respect of patient identity); being a critical partner in care (giving and grounding professional opinion and discuss boundaries); being a developer of client competencies (facilitating and developing client participation within care). The findings offer possibilities to operationalize care concepts aimed at tailored care. Further research aimed at refining and testing the hypothesis developed is recommended.

Keywords: client perspective, demand-driven care, tailored care, client-centred care, recognition, nurse-client interaction, expert patients, grounded theory. 


\section{INTRODUCTION}

A change in the perspective regarding care can be seen in all fields and at all levels of health-care in The Netherlands. Instead of care determined by the professional and by the bureaucracy of the provider, all stakeholders are increasingly becoming aware that the starting points for care are the wishes and demands of patients (Goudriaan \& Vaalburg 1998; VWS, 1999). This allows patients to participate actively in the care-process. There is an increasing emphasis in nursing literature on patient participation (Cahill, 1998; Watersworth \& Luker, 1990; Sainio, Lauri \& Erickson, 2001). However, studies that have examined the desirability of participation from a patient's viewpoint within the context of nursing are limited (Cahill, 1998). The shift towards client centredness is also described in other western countries (Donaldson, 2001; Latvala, 2002). Based upon research and practical experiences in North America and Britain, the British Department of Health signals a shift in the role of the client with a chronic disease from recipients of care into active and responsible partners in care. Expert knowledge is seen as the basis of this shift. New care concepts like 'demand-oriented care', 'demanddriven care' and user-led care' are seen as a response to these developments. These care concepts imply changes not only in the role of the client, but also in the role, interaction and competencies of the professional caregiver. Several authors signal confusion in the application of these new care concepts in practice (Rijckmans, Garretsen, Bongers \& van de Goor, 2002; van der Kraan, 2001).

We wanted to study how clients think about and experience the interaction with the nurse and nurses' aids aimed at tailored care, and what competencies professional caregivers need from the client's perspective. We were particularly interested in patients with a chronic illness and their family caregivers because professional care plays an important role in their lives. To explore the perspective of the client, a qualitative study was conducted. We wanted to answer the following research questions: What is the perspective of persons with a chronic illness and their family caregivers concerning the interaction with the nurse and nurses' aids aimed at tailoring care to their demand? What competencies are required for nurses and nurses' aids?

\section{METHODOLOGY}

Grounded theory (Strauss \& Corbin, 1998) provides a methodology for studying social reality.

Focus group interviews were conducted. We created combined groups of patients and family caregivers because they can be seen as a closely interrelated client-system. Through this method, the intensive interaction within the group stimulates and facilitates the process of exploring and remembering and thus 
elicits rich data (Ashbury, 1995; Webb \& Kevern, 2001). In this study, patient and family caregiver are referred to as 'clients'.

\section{Sample}

Participants were deliberately selected based upon their roles as patient informants of the Dutch Council of the Chronically Ill and the Disabled (www.cgraad.nl ). This is an umbrella organization, consisting of associations of people with a chronic illness or a disability. We expected patient informants to be preeminently able to express a critical view on the central theme of this study. They could draw upon their personal experiences, and on experiences of fellow members of their association. Participants were recruited from a file of patient informants living in the south of The Netherlands by the programme coordinator of the Council. The coordinator was requested to select a variation of participants with respect to: being a client or a family caregivers; age; gender; experience with nursing care and education level. All participants were persons with a chronic illness or family caregivers of persons with a chronic illness.

Oral consent was given by the participants following an oral explanation. All members participated on an independent, voluntary basis.

All informants were living in the south of the Netherlands.

In both focus interviews seven people participated. Six participants participated in both interviews. All participants had experiences with nursing care. Table 1 shows the demographic characteristics of the participants.

Table 1. Demographic characteristics of the participants of the focus groups

$\begin{array}{lll}\text { Characteristics } & \text { Interview } 1 & \text { Interview } 2 \\ & \mathrm{~N}=7 & \mathrm{~N}=7 \\ \text { Patient } & 4 & 4 \\ \text { Family caregiver } & 2 & 2 \\ \text { Both patient and family caregiver } & 1 & 1 \\ & & \\ \text { Female } & 6 & 6 \\ \text { Male } & 1 & 1 \\ & & 4 \\ \text { Age 21-30 year } & 0 & 2 \\ 41-50 \text { year } & 4 & 1 \\ \text { 51-60 year } & 3 & 6 \\ & & \\ \text { Living alone } & 2 & 3 \\ \text { Lives with one or more persons } & 5 & 4 \\ \text { Intermediate vocational education } & & \\ \text { Higher vocational education or university } & 2 & 5\end{array}$




\section{Ethical Approval}

Interviewees were independent patient informants of the Dutch Council of the Chronically illl and the Disabled. Ethical approval was sought in advance individually and granted verbally by all interviewees.

\section{Data collection}

The first interview-guide contained general topics, such as actual and desired behaviour of professionals, facilitating and constraining factors. Themes of the second interview-guide were partly derived from the results of the first session such as: showing respect, being a partner in care, interaction with less competent patients and the role of the family caregiver. Furthermore, care-concepts (demand-oriented and demand driven care) and some related concepts (directing own care, empowerment) were explored. Care concepts were not defined for the participants, because an important starting point of grounded theory is to understand the world of the interviewees as they perceive it. The groups were invited to exchange experiences related to the topics in the interview-guide. This allowed the researchers to discover the range of informants' views. Topics were introduced as open-ended questions. For example 'what do you see as desired behaviour by the professional'. The answers were also explored by probing questions. For example: 'what makes you feel that your experience-based knowledge is not recognized?' To stimulate more hesitant speakers in the group, at the start of the first session, participants were asked to write down shortly their ideas regarding desired care (Stevens, 1996). These notes were assembled by the researcher. At the end of the interview, participant were invited to add unmentioned elements. At the start of the second interview, the new participant was explicitly invited to express her view. Both focus interviews lasted about two hours and were conducted by the same moderator. The moderator, a nurse, had studied health sciences and has a lot of experience in conducting group sessions. All participants stated having experienced an open atmosphere, and having said what they wanted. Observations of both sessions were written down in notes by the researcher. Data were collected during three months in 2002 and 2003.

\section{Data analysis}

Analysis of the data was guided by the principles of grounded theory (Strauss \& Corbin 1998). Data collection and analysis took place concurrently (Webb \& Kevern, 2001). At the end of the second focus interview was reached, as participants repeated information.

During the open coding phase, data were coded according to the type of information presented. Codes were as far as possible taken from words respondents used. 
Through comparative analysis, characteristics of codes and events were grouped together and were given a category label. Criteria for comparison were: care desired; who decides; the care-relationship; actual and desired actions (client and professional); reactions and feelings; barriers and facilitating factors. Conceptually similar events were grouped together to form a framework of categories and subcategories. This framework formed the basis for the phase of axial coding, aimed at exploring the identified (sub)categories more in detail at the level of properties and dimensions. We were particularly interested in variations related to patient characteristics and the role as family caregiver. Both the interviews were coded again, guided by the framework developed. The analysis study stopped after the phase of axial coding. At that time a core category was identified: 'recognition'. Hypothetical relationships between the core category and the major categories were then developed.

\section{Validity and reliability}

The focus interviews were audiotaped and transcribed afterwards. Transcripts were imported into Kwalitan 5.0. Observations were written down in a diary and methodological, analytical and theoretical memo's were made. First impressions and conclusions about process and outcome were expressed during a debriefing with the moderator and the researcher after both focus group interviews. Member checking was performed by the construction of a first-draft report of both interviews, which was sent for commentary (together with the transcriptions on demand) to all participants. Comments of the participants were integrated into a second-draft report. Supplementary remarks were kept as new information. Content validity was established by triangulation of researchers. Two senior researchers experienced in analysing qualitative data were involved in the coding process. Meetings were held to discuss the differences in codes given, so that the analysis could be broadened with new insights. Internal validity was further assured by critical judgement of the applied methodology, analysis and interpretations by all the researchers involved.

\section{RESULTS}

In the client perspective, recognition by the professional of client values underlying their demand (uniqueness, comprehensiveness, continuity of life, fairness and autonomy) and underlying the care-relationship (equality, partnership, and interdependence) emerged as a central element within the interaction aiming at tailored care. Recognition was optimally felt in a dialogue. Four professional competencies could be identified and related to recognition of the client values in dialogue: attentiveness; responsiveness; being a critical partner in care; being a 


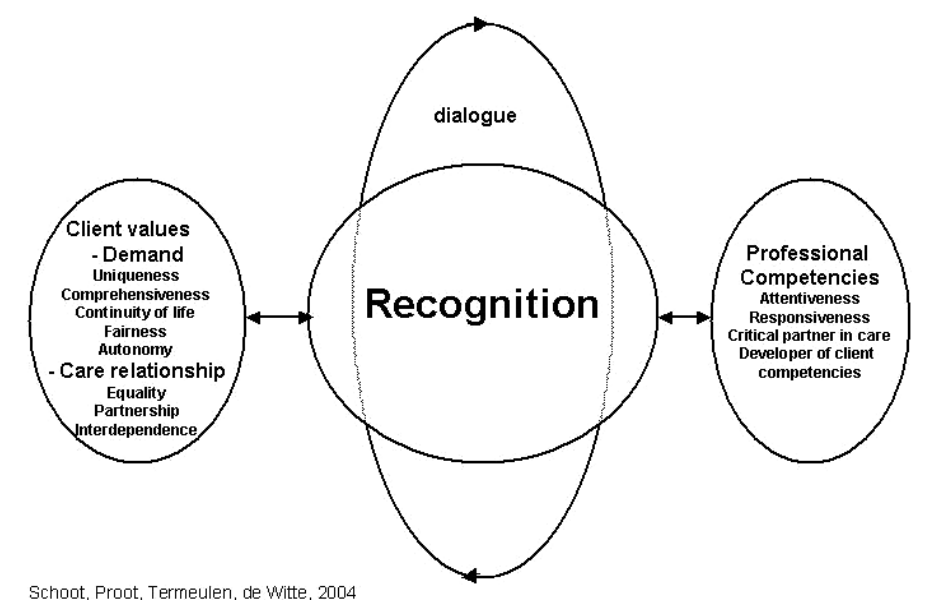

Figure 1. The concept of recognition and related categories

developer of client competencies. Figure 1 shows the concept of recognition and its related categories.

\section{Values underlying the demand}

Participants define uniqueness as attention for and understanding of the client as an individual human being with his/her own life story, beliefs, cultural background and boundaries.

'Yes, I do need help, but they should respect my own dignity. I'm not just a number, as so often happens'. 1p11

As perceived by participants, protocolized care was seen as a threat to uniqueness:

'It's not a uniform care package, full of standards and protocols which someone elsewhere has dreamed up, that I want, but the type of care that suits my illness, my background and my social context'. 1p16

Comprehensiveness concerns the desire to be seen as integral human beings, part of a family system. Care has to support total life and functioning. For example, participants want caregivers to pay attention to emotions and difficulties too.

'Neither should carers run away from unpleasant issues such as fear, pain and inadequacy'. $2 \mathrm{p} 14$

Having a chronic illness also affects the lives of other family members. This could lead to a demand from the family caregiver. 
'Often whilst it's the patient who's at the middle of things, it's left to the family around them - children and partners - to figure it out for themselves [family caregiver]'. $2 \mathrm{p} 3$

Participants stated that integral care puts requirements on documentation and collaboration between all caregivers.

Continuity of life concerns having the opportunity to continue one's life, including one's habits, by getting the care needed. One interviewee said:

' The care provided should help us lead a normal life. After all, we all have our own way of living and our own priorities. Too often we get fobbed off with the attitude that we're just here to help the carers'. $2 \mathrm{p} 17$

Having a chronic illness often implies changing conditions and capabilities (physical and cognitive capabilities, energy, motivation). Continuity of life implies that the professional is flexible regarding the content, the moment and the amount of care that is needed.

'We've all felt that we've had too little support at the moment we most need it ... you get given the support at the moment you least need it or, as the case may be, help that you neither need nor want because it's not your own priority'. $1 \mathrm{p} 16$

Fairness concerns the desire to be treated as having the right to ask for the care needed.

'In my experience, what you ask for is treated as being a favour instead of an entitlement'. 1p4

As perceived by participants, fairness also implies that (temporary) less competent, less self-assertive patients get the care they need, even when they cannot or do not ask for it:

'Okay, as patients we might well be self-assertive, but it's so depressing when you hear some of the stories of those people who fall between two stools'. 1p6

Participants asserted that they wanted autonomy, having the possibility to be who they are, free to live their lives, consistent with their life stories. Self-determination, making your own choices, making your own decisions and setting your own priorities were used as synonyms. These decisions (choices) concerned whether they do want care (including the risks you want to take and the possibility to refuse care) and the content of the care they want. 
'Even though you know how it should be done and whether or not you need the help, if you choose to stumble out of bed, even though it may take five minutes, it's my choice ...' 1p12

In addition to self-determination, taking responsibility and being self-assertive were mentioned as elements:

'... and if I fall, that's my choice and then I have to take the consequences ...' $1 \mathrm{p} 12$

Interviewees frequently used the word 'directing own care', which was explained as being in control of getting the care needed.

'... That a person really is in control of his or her own life, able to decide on his or her own requirements, decide on the kind of care needed and what he or she wants from you ...'2p3

Although participants want to direct their own care, they do appreciate a dialogue with the professional. However, participants stated that, in the end, the client has the final say about his body, home and health.

In case patient competencies were limited, family caregivers were seen as a guarantee of the patient's autonomy:

'... for those who are unable to decide on the spur of the moment. Their relatives and friends often know what's best for them and then the next line of support is the family caregiver, whatever the patient wants. They try to decide from the perspective of the patient's own identity [family caregiver]'. 1p19

\section{Values underlying the care relationship}

Participants regarded themselves in an equal position to the professional. Equality entailed experience-based knowledge being seen just as valuable and necessary as professional knowledge.

'I have a certain demand - the wheelchair must meet certain requirements for me - and that expertise is of equal standing to the expertise of the professional'. $1 \mathrm{p} 4$

Experience-based knowledge (including knowledge about health care systems, possible resources and procedures) was seen as a characteristic of chronically ill patients.

'Particularly those people [have experience-based knowledge] who've been ill for some time who've gained a lot of know-how about their body, how they respond to medication, what they need, what they can tolerate'. 1p7 
Partnership entailed the desire that professionals act as partners in care: accountable, active, collaborating professionals with commitment and having pleasure in their work. The shared aim should be the support of the quality of life of the patient.

'The crux of the problem is that we' $d$ like them to be partners in care because we both have a shared aim, that is to enhance or maintain our quality of life by providing care and supplementary provisions'. 1p6

In turn, participants stated that partnership requires also participation of the patient and family caregiver. In the view of participants, all partners should take responsibility, should communicate expectations and boundaries, make shared care-plans and agreements (including who would speak for, and with the patient), stand by agreements, consult each other and discuss interaction problems.

The desire of mutual receptiveness, understanding, trust and reliance on each other, acceptance and respect of boundaries (including privacy, cultural and spiritual values) was conceptualized by the researchers as interdependence.

'It's not just about the individual patient, or about the individual professional. The interplay between the two is very important'.

Another participant adds:

'.. and also with the so-called client-system, so also with the family caregivers'. 2 p15

Participants admitted the existence of different opinions and (personal, professional and organizational) boundaries, which had to be discussed based upon mutual respect.

'Participate fully in a discussion with respect for each other and each other's interests'. 2 p 14

Participants also mentioned mutual honesty and vulnerability (saying what you are not sure about), and mutual interest and commitment:

\section{Lack of recognition}

Most striking during the focus-group interviews were the verbal and non-verbal expressions of frustration, anger, of feeling mistrusted, inferior, insulted, humiliated, powerless, dependent and anxious. These feelings emerged as expressions of a lack of recognition: 'not being heard', 'not been respected' and 'not taken seriously': 
'As a human being, a unique individual, someone with your own past, you feel you get no recognition. And we all know, if you take one person with a chronic illness and place him next to another person with a chronic illness, you will have two completely different individuals, with a different history of illness, living in different surroundings with different needs'. 1p17

In the client's perspective, lack of recognition appeared to be related to the attitude of the professional. Table 2 presents some examples given by participants. The aspects were clustered by the value they represent.

Table 2. Client values and aspects of the professional attitude characterized by lack of recognition

Client values: demand Aspects of the professional attitude characterized by lack of recognition

Uniqueness

Comprehensiveness

Continuity of life

Fairness

Autonomy

Client values: care relationship

Equality

Partnership

Interdependence
Treating the patient as a number; 'they sacrifice me to their protocol' 'they shelter behind protocols'; automatism

Reduction patient to problem or to a needed activity; no attention to demand of family caregiver

The work of the professional is central (patients have to adjust life habits to professional schedule); lack of intra- and interdisciplinary collaboration

Giving as little care as possible; giving the burden of proof to patients; attitude of prejudice of fraud; attitude as divider of scarce services; too less/ inadequate care for 'under-asking' patients

Patronism (taking over), paternalism (deciding for the patient); arrogance (knowing better)

Aspects of the professional attitude characterized by lack of recognition

Unrecognition of experience-based knowledge; power, not listening to patient; reacting defensively or aggressively to care directions by patients ('that's our business')

Attitude as opponents; using protocols as a 'weapon' within the 'fight'; no opportunity for family caregivers to be involved

Distrust in patient information (checking information with the general practitioner), not taking responsibility/ insecureness (shelter behind rules), lack of privacy and discretion (talking about patients with other patients)

\section{Recognition}

During the analysis, 'recognition' emerged as a recurrent theme within the client perspective concerning tailored care. Firstly recognition concerns client feelings 
of being seen and heard, being accepted and respected and being treated seriously; secondly recognition concerns an attitude of the professional towards the client entailing recognition of the client as a unique, comprehensive, autonomous human being, recognition that (continuity of) life and fairness are central in care, and recognition of the clients as an equal, interdependent partner in care.

The desired attitude was illustrated by a participant by the use of a metaphor of the professional as a guest.

'... because the other person, who's the guest - even when you're lying in a hospital bed-it's important that he or she behaves like a guest, which makes it possible to be yourself and take that person into consideration'. 1p11

In the view of participants, recognition of values refers to tailored care.

'But I'd like the kind of care that's in tune with my illness, my history and social context. That's the kind of care which is efficient and effective. I have MS, that means bladder problems, and a number of years ago I asked for an upstairs toilet, that was necessary because I was living in rented accommodation, ... they put me through the mill ... 'We'll give you a stair lift', they said, but I didn't want one. I was able to get up and down the stairs using the two banisters ... A stair lift costed 14,000 guilders at the time and a toilet was 2,000. Talk about efficiency!' 1p16

Being recognized was optimally felt in a dialogue:

'A respectful dialogue where you take each other seriously, where you recognize that we're both partners in the same game trying to reach the same goals'. $2 \mathrm{p} 7$

Some remarks of participants indicate that recognition leads to feelings of selfesteem, self-respect, human dignity, freedom and autonomy:

'... you can be yourself, everything in your surroundings becomes calmer, acceptance - that is mutual acceptance - becomes much easier ... I do need help, but they should respect my own dignity'. 1p11

\section{Required competencies of the professional}

Four competencies facilitating recognition in dialogue were identified based upon participant's view on the desired nursing attitude, actions, skills and knowledge: attentiveness, responsiveness, being a critical partner in care and a developer of client competencies to participate within care.

'Competency' was defined as a combination of the attitude, skills and knowledge needed to interact successfully. 
Attentiveness covered ongoing actions to get to know and understand the unique, comprehensive client (system).

'What one person considers appealing can be extremely annoying to someone else, that's what you have to find out'. 2 p13

Attentiveness requires verbal and non-verbal communicative skills: sensitiveness, being alert, receptiveness, empathy, real attention, pleasure in work, asking questions and listening.

'As a patient you should be able to notice whether the nurse likes working in that situation - that is, likes looking after you'. 1p7

Responsiveness concerns active, committed and responsible execution of care guided by respect for the client's identity.

Guidelines for care can be implicit (based on knowing the client) or explicit.

'... take cancer patients - if they don't want any more radiotherapy, you have to respect that decision. They're sure to have a reason for not wanting it. 2p14

Participants state that in the first place, professionals have to find out if the client wants to direct (his/her own) care:

'We chronic patients, however, we would very much like to pull the strings. I think the caregivers must have the competence to first find out whether the patient wants to take control him or herself. $1 \mathrm{p} 19$

Help should be complementary for the client, offered instead of being imposed.

Being a critical partner in care means being willing to give and ground your professional opinion, saying what you can offer, searching for a compromise and convincing.

'You have to support your standpoint with arguments. Not just listening and swallowing it lock, stock and barrel, but getting your point of view across with arguments or asking the other person for arguments'. 2 p13

A critical partner in care deals with personal, professional and organizational boundaries in dialogue with the client. Being critical implies self-assertiveness, ethical reasoning, professional knowledge and reflection.

'They should look at themselves in the mirror and ask themselves whether they are dealing with it correctly, if the emphasis is right or whether they have acted too impulsively'. 1p20

Development of client's competencies means to give opportunity to, to motivate and facilitate client participation within the care process. Participants also define 
this as empowerment. Participants mentioned for example: the moment and way of giving and discussing information; making shared care-plans, being alert, being a role model, and referring to a patient-support group. Current professional knowledge was seen as prerequisite.

'Indicate how the procedures work, provide me for example with an indication, because the health care service is like a jungle, show me what the options are and what I can choose'. 1p15

\section{DISCUSSION}

The client perspective concerning tailored care emerged as recognition of a set of values underlying the demand (uniqueness, comprehensiveness, continuity of life, fairness and autonomy) and underlying the care-relationship (equality, partnership, and interdependence). Comparable values underlying the demand were found by Goudriaan and Vaalburg (1998): self-determination, participation in society, individual diversity and justice (in distribution of care).

The concept of recognition emerged as an important theme in this study. The results provide indications that recognition leads to feelings of self-esteem and autonomy in clients and enhances client participation within the care process. A critical question is how the concept of recognition can be related to the concepts of autonomy and self-esteem. The use of the words 'directing own care' by participants seems to point to a liberal view of autonomy (Beachamp \& Childress, 1994), whereas the desired care-relationship points to autonomy as identification (Agich, 2003) and autonomy as communication (Moody, 1992). Directing own care as described by Dutch expert patients goes beyond self management as described in the Expert Patient Document of the UK department of health (Donaldson, 2001). Self management takes place within the boundaries of the medical regime, whereas directing own care shows autonomous choices. The findings of the present study seem to stress the dynamic and contextual character of autonomy in long-term care (Agich, 2003; Proot, Crebolder, Huijer AbuSaad, Macor \& ter Meulen, 2000).

Four professional competencies could be identified related to recognition of the identified values: attentiveness, responsiveness, being a critical partner in care and being a developer of client competencies to participate within the care process. Attentiveness and responsiveness were mentioned by participants related to all values. Being a critical partner in care and a developer of client competencies were particularly mentioned in relation to autonomy, fairness, and in relation to values underlying the care relationship.

Attentiveness, responsibility and competence of the profssional and responsiveness of the client as a receiver of care are described by Tronto (1994) as ethical 
elements of care. Participants value the opinion of a critical, self-assertive professional. Tonkens (2003) supports these findings. Participants also place requirements on themselves as responsible, interdependent partners in care.

It was found that recognition was optimally felt in a dialogue. The dialogue as interaction-strategy to tailor care to the demands of clients is supported by the work of several other authors (Emmanuel \& Emmanual, 1992; Tonkens, 2003). Emmanuel and Emmanuel (1992) outlined four models of physician-client interaction: the paternalistic model; the informative model; the interpretative model and the dialogue or deliberative model. Although all participants in this study stated to prefer the dialogue, some remarks, such as 'wanting to be provided with all relevant information in order to choose the intervention wanted', point to an informative model of interaction.

\section{Limitations of the study}

The findings of this study concern a shared view of expert chronically ill patients and family caregivers. Nothing can be said about the differences between the separate groups.

Based upon their work as patient informants, participants are expected to be more self-assertive than clients generally are. Informants reported that based on their work as patient informants they had become more aware of their individual experiences and possibilities. Asa result, their passive role was turned into the role of an active client. We expect that this role does not have affected their perspective, but mainly their competencies to participate. We expect that the values underlying the demand and the concept of recognition identified are also valid for 'ordinary' patients with a chronical illness and family caregivers. However, there are some indications that under different circumstances, such as impaired client competencies or limited nurse competencies to dialogue, interaction models other than the dialogue may be more appropriate (Emmanel \& Emmanuel, 1992; Sainio et al., 2001).

The total of participants entailed only one male participant, and one participant younger than 30. The general education level was high. Theoretical saturation in the open coding phase was reached after the second focus-interview; hence axial coding was applied with the same data as the open coding. Because of the broad variety of the experiences of the participants, it is plausible that the findings are externally valid. Further research aimed at refining and testing the results with clients with different characteristics is recommended.

\section{Conclusions and implications for practice}

The results of this study offer possibilities to operationalize new care concepts aiming at tailored care. As perceived by the expert patients and family caregivers 
in this study, recognition of client values is the central element of tailored care. Recognition requires an attitude towards the client as a unique, comprehensive, autonomous human being, an attitude that puts (continuity of) life of the client and fairness central in care, and that treats the client as an equal, interdependent partner in care. A dialogue with the client attributes to recognition. Professional competencies needed for recognition in dialogue are: attentiveness, responsiveness; being a critical caregiver and being a developer of client competencies.

\section{Acknowledgements}

The authors gratefully acknowledge all persons involved in the study.

This study was supported by Zuyd University.

\section{REFERENCES}

Agich, G. J. (2003). Dependence and Autonomy in Old Age: An ethical framework for long-term care. Cambridge: Cambridge University.

Ashbury, J. E. (1995). Overview of focus group research. Qualitative Health Research, 5(4), 414-420.

Beachamp, T. L., \& Childress, J. F. (1994). Principles of biomedical ethics. Oxford: Oxford Univerity Press.

Cahill, J. (1998). Patient participation: A review of the literature. Journal of Clinical Nursing, 7, 119-128.

Donaldson, L. M. (2001). The Expert patient: A New Approach to Chronic Disease management for the 21st century. London: Department of health.

Emmanuel, J., \& Emmanuel, L. (1992). Four Models of the Physician-Patient Relationship. JAMA, 267(16), 2221-2226.

Goudriaan, G., \& Vaalburg, A. M. (1998). De vraag als maat (Using demand as a yardstick). Utrecht: Nederlandse Patienten/Consumentenfederatie (NP/CF) and Nederlands Instituut voor Zorg en Welzijn (NIZW).

Latvala, E. (2002). Developing and testing methods for improving patient-oriented mental health care. Journal of Psychiatric and Mental Health Nursing, 9, 41-47.

Moody, H. R. (1992). Ethics in an aging society. Baltimore/London: John Hopkins University Press.

Proot, I. M., Crebolder, H. F. J. M., Huijer Abu-Saad, H., Macor, T. H. G. M., \& ter Meulen, R. H. J. (2000). Stroke patient's needs and experiences regarding autonomy at discharge from nursing home. Patient Education and Counselling, 41, 275-283.

Rijckmans, M. J. M., Garretsen, H. F. I., Bongers, I. M. B., \& van de Goor, L. A. M. (2002). Vraaggerichtheid en vraagsturing. Een poging tot conceptuele verheldering (Demandoriented and demand-driven care: an attempt at conceptual transparency). Tijdschrift voor Sociale Gezondheidszorg, 80, 388-392. 
Sainio, C., Lauri, S., \& Ericksson, E. (2001). Cancer patients' views and experiences of participation in care and decision making. Nursing Ethics, 8(2), 97-113.

Stevens, P. E. (1996). Focus groups. Collecting aggregate data to understand community health phenomena. Public Health Nursing, 12, 170-176.

Strauss, A. L., \& Corbin, J. (1998). Basics of Qualitative Research. Techniques and Procedures for Developing Grounded Theory. Thousand Oaks: Sage Publications.

Tonkens, E. (2003). Mondige burgers, getemde professionals. Marktwerking, vraagsturing en professionaliteit in de publieke sector (Empowering citizens and taming professionals: the market, demand-driven care and professionalism in the public sector). Utrecht: NIZW.

Tronto, J. C. (1994). Moral boundaries: a political argument for an ethic of care. New York: Routledge.

van der Kraan, W. G. M. (2001). Vraaggericht en Vraaggestuurd (Demand-driven and Demand-led). The Hague: ZonMw.

VWS. (1999). Zicht op Zorg: Plan van Aanpak Modernisering AWBZ (Care within Sight:Plan to Reform the General Law on Special Medical Expenses). Den Haag: Ministerie van VWS.

Watersworth, S., \& Luker, K. A. (1990). Reluctant collaborators: do patients want to be involved in decisions concerning care? Journal of Advanced Nursing, 15, 971-976.

Webb, C., \& Kevern, J. (2001). Focus groups as a research method: a critique of some aspects of their use in nursing research. Journal of Advanced Nursing, 33, 798-805. 



\section{ACTUAL INTERACTION AND CLIENT-CENTREDNESS IN HOME-CARE}

Published as:

Schoot, T., Proot, I., ter Meulen, R., \& de Witte, L. (2005).

Actual Interaction and client centredness in home-care.

Clinical Nursing Research, 14(4), 370-393. 


\begin{abstract}
The purpose of this study was to explore client-nurse interaction from a client perspective with respect to client-centred care. A grounded theory study was conducted with chronically ill Dutch clients receiving home care. Data were collected by focus interviews with eight client informants; participatory observations with 45 clients and semi-structured interviews with six clients. The core category 'actual interaction' was identified. Six patterns of actual interaction were distinguished: toeing the line, reluctance, consent, dialogue, consuming, and fighting. Changes in actual interaction could be related to changes in desired participation by the client and in allowed client participation by the professional. From the client's perspective, client-centredness means congruence between desired and allowed participation. Congruence was experienced with consent, dialogue, and consuming. Congruence is not necessarily synonymous with promoting patient participation nor with doing as the client wants. Ongoing attentiveness, responsiveness, promotion of client autonomy, and being a critical caregiver are recommended.
\end{abstract}

Key words: client participation; client-centred care; clients who are chronically ill; communication; client autonomy 


\section{ACTUAL INTERACTION AND CLIENT-CENTEREDNESS IN HOME CARE}

Individualized care has become a topical theme in many health-care systems in western countries such as Western Europe and the United States. Patient-centred care, client-centred care, and demand-oriented care are new care concepts aimed at individualized care. The terms have surfaced in the health care literature as models of service delivery that place the client, patient, or family at the centre of the clinical decision making process (Chewning \& Sleath, 1996; Elwyn, 2001; van der Kraan, 2001).Core concepts that emerge from this literature include patient participation, client autonomy, and shared decision making. The care concept frequently used in the Netherlands is demand-oriented care. It is described as "a collaborative effort of both the client and the professional, resulting in care that meets the client wishes and expectations and at the same time meets the professional standards" (Raad voor de Volksgezondheid, 1998). This definition emphasizes the professional-client collaboration. In connection with these new care concepts, international health-care literature describes a trend in policy and practice towards client empowerment and increased client participation in care. Empirical evidence validates the assumption that the traditional passive role of the patient and the paternalistic approach to patient care are changing. Care is evolving from a professional orientation with the authority of the professional into care guided by the individual autonomy of the client and the right to govern one's own life and health care (Cahill, 1998). In parallel, the client role is assumed to evolve from a passive attitude towards care via an attitude as a responsible recipient of care into a role as an active agent in care (Latvala, 2002).

\section{WHAT IS THE CLIENT'S PERSPECTIVE?}

Patient participation is a complex concept. It is defined, for example, in terms of participation in decision making (Sainio, Lauri, \& Ericksson, 2001), performing clinical or daily living skills (Saunders, 1995) or self-management of care (Donaldson, 2001). Cahill (1998) stated that patient participation is a term that is conceptually similar and often used interchangeably with patient involvement and patient collaboration. Jewell's (1994) conclusion seems to capture all aspects. She reported that patient participation means involvement of the client in clinical practice and decision making via the formal structure of the nursing process or informally through ongoing nurse-client exchange. Cahill (1998), however, states that all nurses' definitions of the concept are purely anecdotal.

Calls for more client participation in care are based on the assumption that clients want to have and do benefit from having a more active role in their healthcare. However, what is the opinion of clients themselves? Studies that have examined 
the value and desirability of participation from a client's viewpoint within the context of nursing care are limited (Cahill, 1998). Because most of the research examining the concept has been based on the doctor-patient relationship, there is a need for further inquiry within the context of nursing practice.

\section{PURPOSE OF THE STUDY}

The aim of the current study was to explore the phenomenon of client-nurse interaction from a client perspective, to better understand the complexity of client-centred care. We studied the following research question:

- How is the interaction of the client with the nurse with respect to clientcentred care?

We were particularly interested in clients with a chronic illness receiving home care from nurses because interaction with the nurse plays an important role in the lives of these clients. The nurses in this study encompass registered community nurses with a bachelor's degree $(\mathrm{Bc})$, registered community nurses, and auxiliary community nurses. Although the views of both nurses and clients were obtained, this paper focuses on the client perspective.

\section{DESIGN}

A qualitative research method was chosen to study client interaction with the nurse because little is known about the client perspective. Grounded theory was used because the theory to be generated fits within practice (Strauss \& Corbin, 1998). The phenomenon of interaction was studied mainly in daily practice. Data collection was based upon theoretical sampling. This means that through the selection of particular nurses and client circumstances, the phenomenon of interaction has been explored. Triangulation of methods (focus group interviews, participatory observations, and semi-structured interviews) was established to broaden the analysis and to secure content validity (Denzin \& Lincoln, 2003; Sim \& Sharp, 1998).

\section{SAMPLE}

The sample consisted of 45 clients having a chronic illness and eight 'client informants'. The client informants, allied to the Dutch Council of the Chronically Ill and the Disabled (CG-Raad), were all expert clients, having experience based knowledge about having a chronic illness beyond an individual level. These persons either had a chronic illness or were a family caregiver of such a person. They could draw upon their personal experiences and on the experiences of 
fellow members of their association. We included family caregivers, because especially in home care, family caregivers are an essential part of the client system, and are also considered to be the nurse's clients. All client informants have had experience with receiving nursing home care, and were living in the south of the Netherlands. Their age varied between 25 and 60 years. Three client informants had intermediate vocational education, five client informants had higher vocational education or university. The 45 clients were clients of eight nurses of the Departments of Nursing and Caring of two home care organizations in the south of the Netherlands. Nurses satisfying the sampling criteria were asked by their managers to participate. For this purpose, managers were given an oral presentation and written information about the aims and approach of the research project. The nurses varied in education level ( 5 registered community nurses $\mathrm{Bc}, 1$ registered nurse and 2 auxiliary community nurses), work experience ranged from $0-$ 27 years; all nurses were the primary nurse of several clients visited, except for one nurse (evening care); five nurses had a particular specialization; the age of the nurses observed ranged from 25-50 years; one half of them worked mainly in villages, one half worked mainly in towns. All nurses worked in middle class and working class neighbourhoods one male nurse participated in the current study; one nurse provided only evening care.

The selection of clients was linked to the planned route of the nurse. This was partly by chance and partly guided by preferences of the researcher in advance. Preferences resulted in variations with respect to medical diagnosis (e.g. cardiovascular disorders, neurologic disorders, respiratory disorders, metabolic and endocrine disorders, neoplastic disorders), phase of the illness (starting disease, stable phase, crisis phase), self-assertiveness, cognitive abilities, experience-based knowledge, gender and age (range 25-93 years).

\section{METHOD}

\section{Data Collection}

Data were collected between November 2002 and June 2003. The eight client informants were interviewed twice using the focus group format. Seven people participated in both focus group interviews. Focus group interviews stimulate and facilitate the process of exploring and remembering by the intensive interaction within each group and thus elicit rich data (Ashbury, 1995; Webb \& Kevern, 2001). The focus group interview questions were open-ended, for example: How do you interact with the nurse? What factors prevent you from interaction or help you interact with the nurse? The exchange of experiences related to these questions allowed the researchers to discover the range of participants' views. The focus interviews lasted about 2 hours and were conducted by the same moderator. 
The participants stated that they had experienced an open atmosphere, and had said what they wanted. Member checking of the focus-interviews was performed by written reports.

Participatory observation was undertaken to get close to the problems or situations occurring in the actual setting. During 7 days, participatory observations of 45 client situations were conducted. The researcher accompanied different nurses from two home care organizations. In order to disrupt the care-process as little as possible, it was agreed that the researcher (registered as a nurse) would participate in the care process if the nurse observed so requested. This meant, for example, passing things, assisting with wound care, or with hygienic care. The interaction between clients and nurses was observed loosely structured by an observation scheme with the following topics: interaction, roles, responsibilities, communication, demand clarification, and decision-making. The duration of a visit was between 20 minutes and 2 hours. With six of the clients visited, additional semistructured interviews were held in order to explore the following topics more deeply from the client's perspective: actions, reactions and the roles of both the client and the nurse; experienced barriers, and factors facilitating client participation.

\section{Ethical considerations}

The research project was discussed with a member of the Central Committee on Research involving Human Subjects (CCMO), leading to the conclusion that further approval with an Ethics Committee was not necessary. Oral consent was given by the members of the focus groups following an oral explanation. For the observations and interviews, informed consent was obtained. Clients were given written information about the research project (aim, privacy, request for consent) by the nurse (at least 1 day before the participatory observation), in a letter signed by the manager of the organization. Clients could give consent to the nurse in advance. At the beginning of the home care visit, the researcher checked additionally if the client was informed and asked again for permission to enter. The nurses received a copy of the informed consent procedure for clients and written agreements for the participatory observation such as anonymity and the role of the researcher.

\section{DATA ANALYSIS}

Focus-interviews and semi-structured interviews were tape-recorded and transcribed. Written reports were made of two semi-structured interviews because these clients felt uncomfortable with the tape-recorder. Participatory observations were written down in reports afterwards. All data were imported into 
Kwalitan 5.0 (Peters, 2000). Methodological, analytical and theoretical memos were made.

Analysis took place simultaneously with the data collection. Four researchers, of whom two were senior researchers, were involved in the coding process. All data were coded independently by two of the researchers. Meetings were held to discuss the differences in codes given, so that the analysis could be broadened with new insights. Peer review clarified how the categories developed and the relationships identified had been reached and were grounded in the data. To obtain a broad variety of codes, open coding was applied to the focus group interviews, 21 situations observed, and 1 individual interview. Through comparative analysis (thinking about properties and dimensions of categories) a number of patterns could be identified by grouping together similar events, such as client actions to express the client demand; nurse's reactions; the care-relationship; and factors related to the client and to the nurse. Based on the client informants, we initially could identify four main patterns of interaction: fighting, toeing the line, dialogue, and consuming. After comparing the data with the individual clients we could add another two patterns: 'consent' and 'reluctance'. Axial coding was applied to a broad variety of data from nine observed situations and from four individual interviews. The aim was to explore the variety within the categories found. Categorizing the data into the interaction patterns helped us to distinguish the core-concept from related categories.

In order to validate these findings, selective coding was applied to 15 participatory observations and with one individual interview. At that time, the core concept developed and related categories were considered saturated, because no new information emerged during this phase.

\section{RESULTS}

Actual interaction between the client and the nurse emerged as the core category. Actual interaction concerns mutual client and nurse activities (or lack of activities). Aspects of actual interaction found were: recognition of care needs, expressing needs and wishes, taking responsibility and initiative in decisionmaking about care (what care, when, how much, by whom, how, where) and management of care. The data also showed variations in intensity of actual interaction. Six patterns of actual interaction have been identified. Beside these patterns, three related categories emerged from the data: desired participation by the client, allowed client participation by the nurse, and client competencies. Figure 1 shows actual interaction and its related categories. 
Client

\section{Professional}

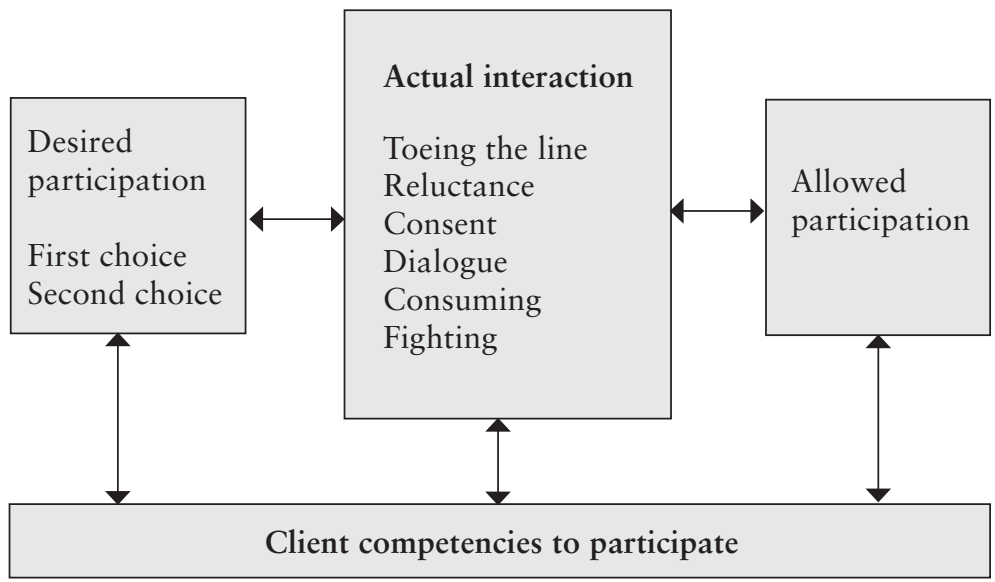

Figure 1. Patterns of actual client-nurse interaction and related categories

\section{Patterns of actual interaction}

Six patterns of actual interaction were identified: toeing the line; reluctance, consent, dialogue, consuming, and fighting. Each pattern turned out to be a compilation of desired participation by the client, allowed participation by the nurse, and client competencies to participate. More than one pattern occurred during one care contact frequently.

Toeing the line. Toeing the line covers situations in which clients obey care decisions made by the nurse and behave in an acceptable way. The demand is covered. There is no recognition of the client demand by the nurse. Clients do not participate in the way they desire. Clients avoid confrontation.

A widow, aged 86 with diabetes, suffers from ulcers related to venous stasis. She relates: "The night nurse-aid suggested coming round at 6, as it fitted in better with her schedule. I told her it was fine, I don't mind at all. But afterwards I start thinking, well, actually it's too early for my leg and not really beneficial. The other thing is, I'll have nothing to do and I'll be stuck in my room. Well, I suppose if it helps the nurse ..." 
An aged woman receives assistance with bathing and with her compression stockings. The nurse encourages the client to do some things by herself. The woman explains that she has difficulty in bending down and reaching her feet and then, somewhat disapprovingly, goes on to say, "The family care service always does it for me when they're here". The nurse explains that it's important she does as much as possible for herself. It will encourage her to be more independent. The woman stays silent and just gets on with her task.

Clients who toe the line were partly negative and discouraged, and partly positive and making the best of it. Several factors were related to toeing the line: thinking there is no point in expressing their demands, being afraid to lose available care, being very ill and having (temporarily) impaired cognitive abilities, submitting to the interests of the nurse, because of understanding of the nurse and her situation. Clients who predominantly had experiences with an authoritarian nurse wanted and expected the nurse to make decisions and the clients to do as they were told. Some clients thought active participation (e.g. saying what you want and don't want) was not appreciated. Several clients toeing the line were able to be very selfassertive with well developed social skills. Instead of fighting for desired participation, diplomacy, tact, and courtesy were devoted to staying on speaking terms with the nurse.

Reluctance. Reluctance concerns lack of commitment with, and avoidance of nursing care by clients although clients seemed to value the social attention. We observed clients turn down proposals, as well as indirectly showing hesitation and disapproval afterwards. The client expresses no demand, or denies the demand. In the case of reluctance, the client desires less participation than allowed by the nurse. It is the nurse who identifies a need, who takes responsibility, and who is in charge.

An aged farmer has necrosis of the toe.

Nurse: He's very easy-going, whether you do things well or not ... He doesn't ask for anything, which can be very tiring. I've tried offering him all sorts of equipment (bed, walking frame, wheelchair) but none of it is quite what he wants.

Man: No problem, all in good time.

Nurse: Because he's not bothered, you start to think, why bother myself. But what if nothing happens? Before you know it, they'll never get anything they really need and what they are entitled to.

The husband of a client with a serious lung disorder is talking about the provisions he's been applying for (e.g. raised toilet, night-time commode). The woman makes non-verbal signals that she'd rather not hear. When the 
observer asked later, the woman said she didn't want anything: "I wasn't ready for it."

Reluctance towards nursing care was present in several situations: if the nurse adopted paternalistic behaviour not desired by the client, if the client did not want to lose care provided by a family member, if clients were not motivated due to their coping process. Some clients were not willing to spend money on services or resources. When the nurse assumed impaired client cognitive abilities, the desire for no nursing intervention was not allowed out of beneficence.

Consent. Consent entails client activities aimed at conforming with and adhering to the opinion and advice given by the nurse. Clients are attentive, responsible followers of suggestions of the nurse. In this pattern clients want the nurse to make decisions, while the nurse is willing to do so. Clients believe that nurses know what is best for them. Informed consent is given to the nurse, sometimes afterwards. The client is sometimes eager to please the nurse.

In one instance, the man says that he wasn't feeling too good and would rather not go to the day centre. The nurse ignores his remark, remains calm and friendly, goes to the bathroom and turns the taps on. She distracts him. The man goes to the bathroom. His insight is limited. Afterwards, the man sits down enjoying a cup of coffee. The observer asks him: "What do you think about the nurse not doing what you wanted to do?" The man replies, "That's fine. Otherwise I wouldn't have gone. And I like to go to the day centre."

A 50-year old man was referred to a diabetic consultation as a result of too high a blood sugar level. He comes in and says, "Please, tell me". He looks anxious. The talk is based on a questionnaire for people with diabetes. The nurse says that she will consult with the GP about medication and call him about this later. The man asks if he needs to come back. The nurse: "I'll make an appointment for you in 3 months' time". The man thought that was just fine.

Consent was seen in older clients, in anxious clients, in situations requiring new skills and knowledge. Diminished cognitive functioning (e.g. in stroke) seemed to contribute to the desire for consent, as did receiving consultation at the location of the general practitioner and the use of standard assessment forms.

Dialogue. A dialogue manifests as a process of interactive discussion between equal, interdependent partners in care. The experience-based knowledge of the client is valued as equal to professional nursing knowledge. Interdependence refers to mutual respect, trust, commitment, and responsibility. The dialogue entails an ongoing clarification of the demand and respectful exchange of ideas 
and information, including individual, professional, and organizational boundaries. Client wishes and needs are central. Clients perform actions such as telling about themselves, saying what they want, and asking for the opinion of the nurse. Nurses perform actions to get information and understand the client's identity and the client's wishes and demands (attentiveness). We saw the nurse behave as a critical partner in care by giving and grounding a professional opinion and discussing personal, professional, and organizational boundaries.

A young woman has a colostomy. It's leaking. A number of questions are asked to discover the problem as well as what was done in the past and how she felt about this. A lot of attention and understanding is given to the woman's situation. The nurse uses her own expertise, but acknowledges her own limitations. The benefits, drawbacks, and costs of the various drainage systems are discussed. Together they decide to try out a new drainage system. Follow-up appointments are made. Afterwards the woman says that she feels taken seriously.

A woman has an indwelling bladder catheter. After a bladder washout the woman expresses a wish to close the catheter. She's expecting visitors that afternoon. The primary nurse points out the risks of infection. The woman listens carefully, but she points out the social inhibitions caused by a urine collection bag. The nurse respects her decision and helps the woman to fit the closure system. The woman says she will apply the day collection system as soon as her visitors have left. The woman appreciates having been given some dignity.

In the situations observed, care decisions included potential problems. Selfgovernance appeared to be subordinated. Both client informants and individual clients reported that being a partner in care increases feelings of self-esteem. Being treated as a partner seemed to facilitate participation in care (e.g. thinking along with nurse). Clients who had been facilitated to actively participate earlier, desired and expected to become involved in the care-process. Most of the client informants preferred a care-relationship over a business relationship (consuming) because of the experienced self-esteem as a partner. Clients showing this pattern were of all ages and varied in self-assertiveness and cognitive abilities.

Consuming. Consuming covers clients deliberately choosing the interventions, services, and resources they need and wish. The nurse acts as the client wants. What the client wants is expressed accurately. Consuming was seen in clients who value independence and self-governance. Client informants stated that care was increasingly becoming a business. This was also observed, for example the scanning of care delivered with a barcode. Several client informants stated that as a 
consumer they felt in the position of client as king and that they experienced more status in the interaction. Some clients even reported that a care relationship was avoided because of emotional dependency. All client informants agreed that full responsibility lies with the consumer.

A very aged woman living alone has venous insufficiency and rheumatism. She receives a personal care budget for home care. The woman issues clear instructions on how the compression stockings should be put on and taken. She watches closely how it's done. She corrects the nurse-aid. "I really hate having to ask ... especially when it's something I used to be able to do myself, as well as the fact that I see things being done which don't agree with me...I'd like to have my independence back the most."

The woman makes plain that paying for the care increases her sense of independence.

Client informant 1:.. it's fine that we've reached the stage where patients have become clients, but we should really be making them consumers of the Dutch welfare state, to which, if it does something wrong, we should all have the right of redress. The same as if you were taking a carton of milk back to the supermarket which had gone off.

Client informant 2: Yes

Client informant 3: It's a real turnaround, but I think it's to everyone's benefit. Nowadays, I think the client and the nurse both know where they stand.

Consuming was related to having the financial resources allowing clients to stress their wishes. In the observed situations, consuming was particularly seen with domestic services. Costs of care services played an important role in care decisions. In a few situations consuming was reported as a reaction to inappropriate care. Clients who chose the pattern consuming had expert knowledge about care needed, possibilities and rights, were self-assertive, and cognitively competent. Clients reported they had to express their wishes accurately and know their way in the health care system.

Fighting. Fighting emerged as client activities, executed with great determination, aimed at getting the care and participation desired. Clients seek confrontation in many ways such as complaining, writing a letter to the manager, making a request (in advance), bringing pressure, proving that you are right, and playing nurses off against each other. Sometimes fighting occurred in a more positive way such as by diplomacy and humour. Desired involvement in care is made explicit and overt. There is no recognition of client wishes by the nurse. Care decisions are predominantly made by authoritarian nurses, and guided by protocols and professional values. Fighting is used when client priorities were at stake, such as the moment of 
care, diminishing frequency of care, and decisions concerning the living situation.

A 40-year old woman with muscular dystrophy says she'd rather not be dependent. "You should be able to stand on your own two feet. I've always had a way with words, for example, the morphine pump which was leaking. It was only when I pointed it out that they actually did anything. It's a daily struggle as it is, without having that on top as well. 'After a certain point, you just get fed up with fighting. At the end of the day, I just don't have any energy left."

A man is catheterized twice a week to keep a urine stoma open. Afterwards he receives assistance in taking a shower. The man has mobility problems. As the man is showering, the nurse says irritably, "If he used a brush, he could take a shower without our help. I'm not really needed, but he won't listen. He's afraid of falling. If it was up to him, we'd be here 7 days a week." Afterwards the observer asks the man, "If you had the choice of care, what would you want to see changed?" The man replies, "I wouldn't want visits any more often; on the days that I go to the day centre, I'd like them here at 8 a.m." The nurse answers, “Before 9 o'clock! There's no way we can guarantee that. There are only three nurses who can catheterise".

In the situations analysed, clients were frequently frustrated or desperate. Negative emotions contributed to presenting a desired care aggressively as a claim or as a right. Fighting back by the nurse was seen in the case of very demanding clients. In several cases, fighting dominated the whole interaction. Fighting for selfgovernance was particularly reported by self-assertive clients in a good condition with sufficient courage and time. Knowledge about care possibilities needed and rights seemed to contribute to the urge for fighting. With several clients fighting for less self-performance of daily activities, the client and the nurse seemed to value independence differently. Fighting was seen in clients of all ages. Fighting followed by toeing the line was reported and observed. Fighting sometimes led to allowance of desired participation.

\section{Actual interaction and participation}

Actual interaction appeared to be a two-sided process in time. Changes in actual interaction can be related to changes in desired participation by the client and to changes in allowed participation by the nurse. Client competencies to participate in care emerged as a category, influencing desired participation, allowed participation, and actual interaction. Table 1 shows details of the patterns of actual interaction and the related categories. 

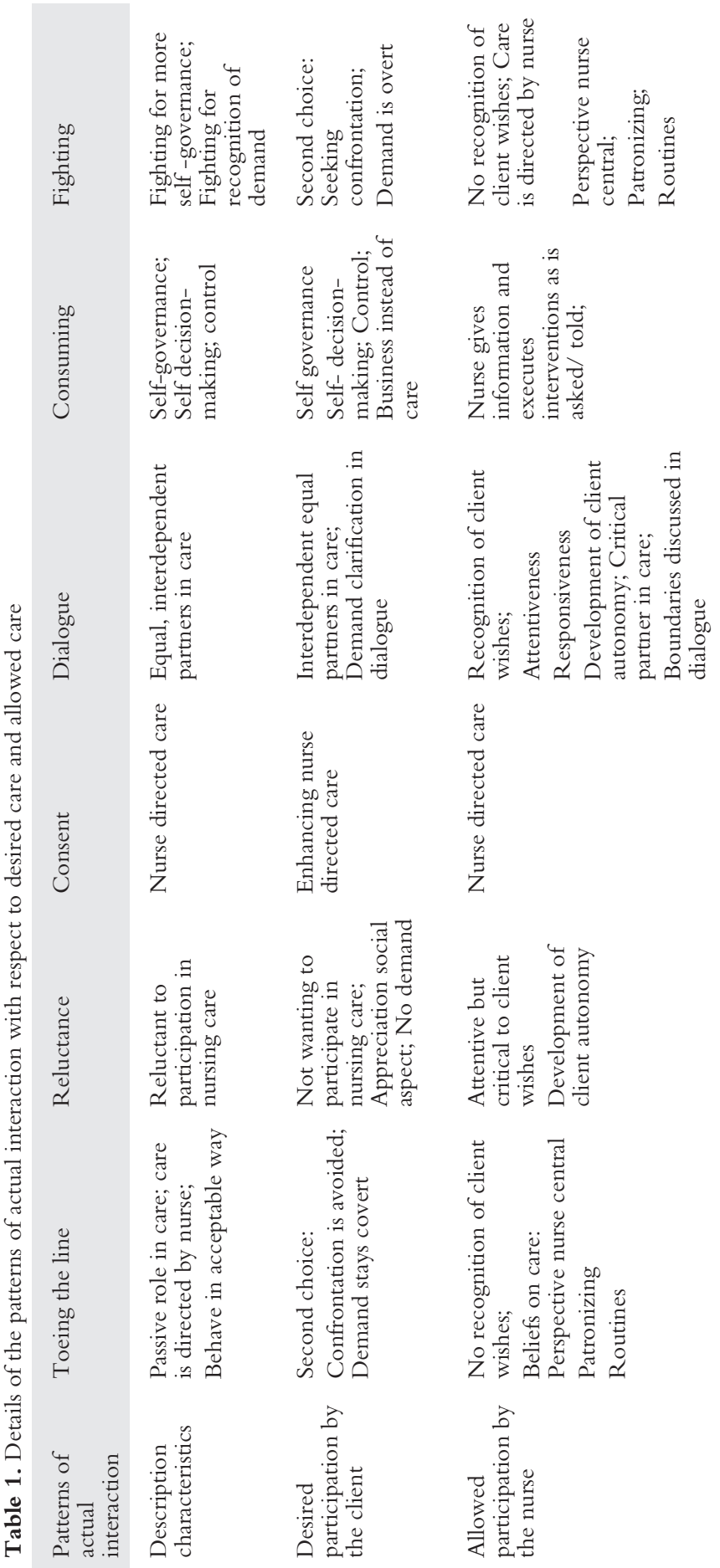


\section{Desired participation}

Desired participation by the client encompasses desired responsibility and initiative in decision-making, desired management of care, and desired independence in care performance. The patterns of actual interaction reveal that clients differ in aspects, ways, and the extent to which they desire to participate in care over time. Desiring a more passive role as a client often implied desiring more involvement in care by the nurse and vice versa. We could distinguish clients preferring a more passive role, including approved paternalism (consent); clients wanting shared participation in care (dialogue); clients wanting intensive participation (consuming); and clients not wanting to participate in nursing care (reluctance). If the particular kind of participation that the clients desired was not allowed, clients seemed to have a second choice of desired participation: wanting confrontation (fighting) or not carrying matters to an extreme (toeing the line). Client competencies such as lack of energy and impaired cognitive abilities influenced the desired participation in a negative way. Client competencies such as expert knowledge and energy contributed to the desire to participate intensively. Several other factors influenced desired participation by the client: personality and preferences, beliefs on care, the nature of the demand, coping process, and age. The findings reveal that desired participation is influenced by previous experiences of the client with respect to interaction in the care process. Clients who were facilitated by a nurse or by a doctor to participate actively, desired and expected to become involved, while clients who mainly had experienced directive professionals wanted and expected the nurse to make decisions.

\section{Allowed client participation by the nurse}

Allowed client participation by the nurse concerns the nurse's attitude and support towards the client with respect to whether, and to what extent participation is allowed and/or supported. The different patterns reveal variety with respect to attentiveness and recognition of client wishes, responsiveness to client wishes, being a critical professional with respect to client wishes, and development of client autonomy. Client competencies play an important role in whether and to what extent client participation is allowed by the nurse. For example in the case of impaired cognitive abilities (e.g. the pattern reluctance), beneficence interferes with client wishes. Other factors related to allowed participation are: nurse's values and beliefs towards both the roles of the nurse and the client and organizational boundaries. Several impediments in the work environment may restrict allowed participation, such as the presence of protocols, heavy workload (due to the scarcity of nurses and high staff turnover with respect to holidays and illness), central planning of work processes, and a task-oriented nurse system. A 
primary-nurse system and decentralized planning of care seemed to facilitate the allowance of desired participation in care.

\section{Patterns of actual interaction and client-centredness}

The intensity of client participation in the interaction in the different patterns can be set out on a continuum (see figure 2) that ranges from low intensity of client participation (toeing the line) to intensive participation (fighting). The pattern dialogue shows an overlap with two other patterns: consent and consuming. With these patterns characteristics of the pattern dialogue may occur and vice versa. The horizontal line in figure 2 divides the patterns roughly according to the presence or absence of client-centred care, as experienced by the clients. The findings of this study indicate that client-centred care is about congruence between desired and allowed participation. The upper part visualizes the patterns in which clients experienced congruence or client-centred care: consent, dialogue, and consuming. The lower part visualizes the patterns in which clients experienced lack of congruence and absence of client-centred care: toeing the line, reluctance, and fighting. Levels of client-centredness were not further explored in this study.

\section{Care is client-centred}

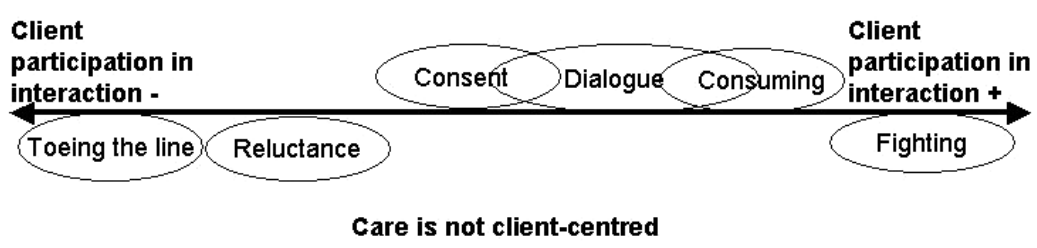

Figure 2. Patterns of actual interaction positioned with respect to the intensity of client participation within the interaction and with respect to client-centred care

\section{DISCUSSION}

In this grounded theory study, the core category 'actual interaction' was identified. Six patterns of actual interaction were found: toeing the line, reluctance, consent, dialogue, consuming, and fighting. More than one pattern appeared to occur during one care contact frequently. Variations in the presence of a certain pattern could be related to differences in desired participation by clients, differences in client competencies to participate in care, and differences in allowed participation by the nurse. 
The findings of the current study stress that client-centred care is about congruence between desired and allowed participation. Congruence was seen in the patterns consent, dialogue, and consuming. No congruence was seen in the patterns toeing the line, reluctance, and fighting. The results show that clientcentredness is not necessarily synonymous with promoting client participation within the interaction.

Emmanuel \& Emmanuel (1992) outlined four ideal types of the physician-client interaction: the paternalistic model, the informative model, the interpretative model, and the deliberative model. It is noted by these authors that these models are not limited to the medical realm but also may inform public conceptions of other professional interactions. The paternalistic model seems close to the pattern consent in the present study. The interpretative model and the deliberative model fit into the dialogue. The informative model shows similarities with consuming, as the patterns of the present study are. The patterns characterized by a lack of congruence do not fit within the ideal types as described by Emmanuel and Emmanuel. What clients want, are able to do, and are allowed to do, is described by van Haaster (2001) as elements of client competency and as the basis of active client participation.

Toeing the line is used by (Watersworth \& Luker, 1990), to describe clients who accept to participate in care, even if they do not really want to. In both the present study and the study by Watersworth and Luker, there is a discrepancy between desired care and allowed care, however, the latter focuses mainly on examples of clients desiring less participation.

Reluctance of clients in the case of impaired cognitive abilities (e.g. after stroke) raises ethical questions for nurses in deciding what weight to attach to the wishes and intentions the client expresses. One issue concerns client wishes that seem irrational, or against the client's best interests. Because in western society we accept that autonomy is a valuable part of people's lives (Schoot, Proot, ter Meulen, \& de Witte, 2005; Sim, 1998), nurses have the obligation to respect the autonomy of their clients. Respect for autonomy requires that client wishes should be honoured whereas beneficence requires that client's wishes should not be honoured if they are deemed irrational or against the client's best interest (Sim, 1998). Paternalism may occur in the case of interference with a person's liberty of action justified by reasons referring exclusively to the welfare, good, happiness, needs, interests, or values of the person being coerced (Dworkin, 1988).

Consent reveals that under certain conditions some clients prefer a more passive role in care. Consent is close to compliance, although the compliance concept does not fit with a client-centred approach, as it often implies client obedience (Burger, 1997). Consent implies that the client and nurse agree about the aim of care. The World Health Organization considers participation not only as desirable, but as a social, economic, and technical necessity (WHO, 1984). The 
dilemma is the change from what was initially stated as a right to a more rigid standard. A critical question with respect to consent concerns the obligation of the nurse to put the client's interests above his or her own and consulting others when adequate knowledge lacks.

A dialogue emerges as a dynamic process over time, however, in (medical) literature it is often described as a clearly defined moment of shared decision-making (Elwyn, 2001). The dialogue is presented by several authors as a mechanism to enhance clients' self-understanding and self-determination (Agich, 2003; Emmanuel \& Emmanuel, 1992; Pool, Mostert, \& Schumacher, 2003). Agich, (2003) expresses this as follows: "choice that enhances autonomy is choice that is meaningful for individuals and allows them to express and develop their own individuality"(p.117). This view of autonomy is also called positive freedom (Berlin, 1969). The recent call for patient autonomy has been frequently conceived in terms of freedom to choose and self-governance. This view of autonomy is also called negative freedom (Berlin, 1969).

Consuming is related to new care concepts such as demand-driven care or clientdirected care (van der Kraan, 2001). The entry of consumerism into health-care systems has led to clients becoming more actively involved in the provision of health care. In several western countries a budget-system has been developed in which clients are free to decide what form of care they buy and from what provider (van der Kraan, 2001). It is estimated that in this way two goals are achieved: clients are given a greater say in their own situation while organizations compete on quality and effectiveness. An emancipated citizen and a market mechanism are seen as alternatives for bureaucracy and professional oriented care, however, consuming embodies a defective view on patient autonomy and reduces the professional role to that of a health care provider or technologist (Emmanuel \& Emmanuel, 1992; Tonkens, 2003). Client informants in the present study signalled an increasing dichotomy in clients receiving appropriate care and those who are not, based upon the client competencies required to direct care.

Many descriptions of fighting against prejudice, oppression, and discrimination have been found in literature (Bellemakers \& van Houten, 1996; Morskieft, 1998). Patients who are not willing to carry out the measures derived from objective facts (such as evidence) have repeatedly been labelled as noncompliant (Burger, 1997).

In general, several studies examined similar factors influencing participation in care such as poor health, age, beliefs on care, desire to be a good patient, expert knowledge, previous experiences, and poor interactive relationships (Cahill, 1998; Henderson, 2002; Sainio et al., 2001; Watersworth \& Luker, 1990), it is difficult however, to compare these findings with the results of the present study 
because of differences in client characteristics and characteristics of the context of care.

\section{Strengths and weaknesses}

This study concerns chronically ill clients receiving home care by nurses and auxiliairy nurses in the south of the Netherlands. Because of the broad variety of clients and client situations, it is plausible that the central concepts found and their relationships are also valid for other chronically ill clients receiving home care in the Netherlands.

The combination of several methods of data collection, retrospectively and concurrently, contributes to the strengths of the current study. This combination chosen provided the benefit of time to reflect on the meaning and significance of clients' experiences (focus group interviews), and the advantage of observing details of events, not distorted by the lapse of time (participatory observations). The use of codes as closely to the data as possible and peer debriefing with the researchers involved, contributed to the trustworthiness of the study (Guba \& Lincoln, 1989). Validation by means of feedback by participants on the analysis was only applied with the participants of the focus groups. Theoretical sampling guided purposeful attempts to find varying people and situations to explore the variety within the categories. Variations were limited, however, with respect to gender of the nurse and of the client informants. Only one male client informant and one male nurse participated in the study.

Further research into experiences of other client groups (such as acute clinical care), into the relationship between the education level of the nurse and interaction with the client, and into ethically difficult situations as experienced by nurses is recommended.

\section{APPLICATION TO PRACTICE}

The results of this study stress the role of the nurse with respect to client participation and autonomy. Instead of the standard promotion of client participation, client-centredness is about congruence between desired and allowed participation. The study shows that in different conditions, different patterns may be appropriate. Providing client-centred care includes respecting the conscious desire of some clients to take (temporarily) a more passive role. Individualized care obliges nurses to ascertain on a continuous basis in which way and to what extent clients really want to participate in care. Ongoing attentiveness aimed at clarifying client wishes and competencies and being responsive to client wishes on the one hand, and being a critical caregiver and developer of client autonomy on the other is recommended as the basis of client-centred care. It allows clients to 
reflect on what they value and thus contributes to client autonomy as enhanced self-understanding and self-determination. Allowed participation does not mean allowing everything the client wants, but a role as critical caregiver (Schoot et al., 2005; Tonkens, 2003). In case of conflicting values, the nurse should explore the worthiness of certain values together with the client instead of imposing them. The findings stress the importance of reflection by professionals on desired care and allowed care (Schön, 1987).

\section{Notes}

The authors gratefully acknowledge all clients, family caregivers, nurses and auxiliary nurses who were involved in the study. They also thank Godelief Mars for her part of the analysis of the study.

The study was financially supported by Zuyd University.

\section{REFERENCES}

Agich, G. J. (2003). Dependence and Autonomy in Old Age: An ethical framework for long-term care. Cambridge: Cambridge University.

Ashbury, J. E. (1995). Overview of focus group research. Qualitative Health Research, 5, $414-$ 420.

Bellemakers, C., \& van Houten, D. (1996). Het leven en de zorgen van mensen met een chronische ziekte (Life and concerns of people with a chronical illness). Praktische Humanistiek, 6(2), 12-24.

Berlin, I. (1969). Two concepts of liberty. Four essays on liberty. Oxford: Oxford University Press.

Burger, W. (1997). The relation between medical education and medical profession's world view. Medicine, Health Care and Philosophy, 4, 79-84.

Cahill, J. (1998). Patient participation: A review of the literature. Journal of Clinical Nursing, 7, 119-128.

Chewning, B., \& Sleath, B. (1996). Medication decision-making and management: A clientcentred model. Social Science and Medicine, 42, 389-398.

Denzin, N. K., \& Lincoln, Y. S. (Eds.). (2003). Collecting and Interpreting Qualitative Materials (second edition ed.). Thousand Oaks: Sage Publications.

Donaldson, L. M. (2001). The Expert patient: A New Approach to Chronic Disease management for the 21st century. London: Department of health.

Dworkin, G. (1988). The theory and practice of autonomy. Cambridge: Cambridge University Press.

Elwyn, G. (2001). Shared decision making: Patient involvement in clinical practice, Dissertation. Nijmegen: Katholieke Universiteit Nijmegen.

Emmanuel, J., \& Emmanuel, L. (1992). Four Models of the Physician-Patient Relationship. $J A M A, 267(16), 2221-2226$.

Guba, E. G., \& Lincoln, Y. S. (1989). Fourth Generation Evaluation. Newbury Park: Sage Publications. 
Henderson, S. (2002). Influences on patient participation and decision-making in care. Professional Nurse, 17, 521-525.

Jewell, S.E. (1994). Patient participatio: What does it mean to nurses? Journal of Advanced Nursig, 19, 433-438.

Latvala, E. (2002). Developing and testing methods for improving patient-oriented mental health care. Journal of Psychiatric and Mental Health Nursing, 9, 41-47.

Morskieft, M. (1998). Om te lachen, om te huilen (Laughing matter, crying matter). Versie: Tijdschrift voor Politiek, Gezondheid en Burgerschap, 16(1), 36-37.

Peters, V. (2000). Kwalitan 5.0. Nijmegen: Katholieke Universiteit Nijmegen.

Pool, A., Mostert, H., \& Schumacher, J. (2003). De kunst van het afstemmen (The art of finetuning). Utrecht: NIZW.

Raad voor de Volksgezondheid (RVZ), (1998). Naar een meer vraaggerichte zorg (Towards increased demand-orientedness). Zoetermeer: Raad voor de Volksgezondheid.

Sainio, C., Lauri, S., \& Ericksson, E. (2001). Cancer patients' views and experiences of participation in care and decision making. Nursing Ethics, 8, 97-113.

Saunders, P. (1995). Individualized care. Encouraging patients to take part in their own care. Nursing Times, 91(9), 42-43.

Schön, D. A. (1987). Educating the reflective practitioner. San Francisco: Jossey-Bass.

Schoot, T., Proot, I., ter Meulen, R., \& de Witte, L. (2005). Recognition of client values as a basis for tailored care: the view of Dutch expert patients and family caregivers. Scandinavian Journal of Caring Sciences, 19, 169-176.

Sim, J. (1998). Respect for autonomy: issues in neurological rehabilitation. Clinical Rehabilitation, 12, 3-10.

Sim, J., \& Sharp, K. (1998). A critical appraisal of the role of triangulation in nursing research. International Journal of Nursing Studies, 35, 23-31.

Strauss, A. L., \& Corbin, J. (1998). Basics of Qualitative Research. Techniques and Procedures for Developing Grounded Theory. Thousand Oaks: Sage Publications.

Tonkens, E. (2003). Mondige burgers, getemde professionals. Marktwerking, vraagsturing en professionaliteit in de publieke sector (Empowered citizens and tamed professionals: the market, demand-driven care and professionalism in the public sector). Utrecht: NIZW.

van der Kraan, W. G. M. (2001). Vraaggericht en vraaggestuurd: Een literatuuronderzoek naar vraaggerichtheid en vraagsturing in de gezondheidszorg (Demand-oriented and demand-driven. A review of the literature into demand-oriented and demand-driven care in the health-care sector). The Hague: ZONMw.

van Haaster, H.P.M. (2001) Cliëntenparticipatie (Client Participation). Bussum: Coutinho.

Watersworth, S., \& Luker, K. A. (1990). Reluctant collaborators: do patients want to be involved in decisions concerning care? Journal of Advanced Nursing, 15, 971-976.

Webb, C., \& Kevern, J. (2001). Focus groups as a research method: a critique of some aspects of their use in nursing research. Journal of Advanced Nursing, 33, 798-805.

World health Organization (WHO), (1984). Health education in self-care: possibilities and limitations. WHO Newsletter, 1(2), 5-7. 



\section{CLIENT CENTRED HOME CARE: BALANCING BETWEEN COMPETING RESPONSIBILITIES}

Published as:

Schoot, T., Proot, I., Legius, M., ter Meulen, R., \& de Witte, L. (2005).

Client-centred home-care: Balancing between competing responsibilities.

Clinical Nursing Research, 15 (4), 1-24. 


\begin{abstract}
This study explores and describes the perceptions of nurses with respect to everyday client-centred care. A grounded theory study was conducted with ten Dutch nurses and auxiliary nurses giving home care to chronically ill clients. Participatory observations and semi-structured interviews were held. Nurses perceived roles and responsibilities competing with the role as a responsive professional to the client demand: a critical professional, developer of client competencies, individual, and employee. Strategies in balancing between competing responsibilities were distinguished: pleasing, dialoguing, directing, and detaching. Directing (related to impaired client competencies) and detaching (related to organizational barriers) were also used as second choice strategies. Effectively balancing between competing responsibilities was seen in dialoguing and directing as second choice. Conditions identified related to these strategies are awareness of, and responsibility taking for competing responsibilities. Recommendations for practice concern a care relationship and a dialogue with the client, critical ethical reflection, professional autonomy, self-assertiveness and organizational support.
\end{abstract}

Key words: client-centred care; awareness, responsibility taking, dialogue, ethical reflection. 


\section{CLIENT-CENTRED HOME CARE: BALANCING BETWEEN COMPETING RESPONSIBILITIES}

Individualized approaches to care have gained increasing emphasis in the delivery of care and have become a topical theme in health-care systems in many western countries (Cahill, 1998). Client-centred concepts of care take client autonomy as the starting point for care (Chewning \& Sleath, 1996; Van der Kraan,2001). Core concepts that emerge from this literature include patient participation, client autonomy, and shared decision-making (Elwyn, 2001; Jewell, 1994; Sainio, Lauri, \& Ericksson, 2001). The care concept frequently used in the Netherlands is demand-oriented care. It is described as 'a collaborative effort of both the client and the professional, resulting in care that meets the client wishes and expectations and at the same time meets the professional standards (RVZ, Council for Public Health, 1998). Current developments point to simultaneous demands other than the client demand. The aim of this paper is to describe and explore how nurses and auxiliary nurses perceive the realization of everyday client-centred care in the context of different, simultaneous demands.

\section{BACKGROUND}

Home care concerns nursing care, family care, treatment and support provided in the homes of clients by professionals, and supported by the client's self-care, informal carers and volunteers. A particular purpose is to enable clients to remain at home as long as possible (NRV, 1989). Under the provisions of the Exceptional Medical Expenses Act (AWBZ), all residents of the Netherlands are entitled to receive community nursing care. The financing of home care is based upon a copayment system.

Home care services are centred on the needs and demands of clients (NRV, 1989). There is pressure for health professionals to change from a providerdirected perspective on care, focusing on diseases and their management, to a client perspective in which people, their lives, autonomy and participation are central (Nu'91/LCVV, 1998; van den Bos, Frijling, Koster-Dreese, Schnabel, \& Spreeuwenberg, 1999). This is reflected increasingly in the policy of care organizations.

Current developments point to demands of different stakeholders other than the client, existing at the same time. The introduction of market forces has led to budgeting, calculated in terms of products, product prices and productivity (de Klaver \& Scholten, 2002; STOOM, 2002; van Rooij, Droyan Kodner, Rijsemus, \& Schrijvers, 2002). Under the AWBZ, clients are entitled to a set amount of home nursing care. Because of efficiency pressures and cost containment efforts, the home care sector has an independent central needs assessment 
centre. The Dutch Quality of Care Institutions Act and the Individual Health Care Profession Act put general requirements for 'proper care'. Besides clientcentredness and care meeting the real client demand, good quality care, effective care and efficient care are mentioned. Dilemmas with respect to client-centred care are described at policy level (Terpstra, 1997) and with long-term care settings (Elander, Dreschler, \& Persson, 1993). Little is known about home care nurses' perceptions regarding their realization of everyday client-centred care in the actual context.

\section{PURPOSE}

The aim of this study is to explore nurses' and auxiliary nurses' perceptions and actions with respect to their realization of everyday client-centred care in order to better understand its complexity and hence to promote it adequately. To do so, we explored the following question: How do nurses and auxiliary nurses perceive the realization of everyday client-centred care?

We were particularly interested in nurses and auxiliary nurses giving everyday home care to clients with a chronic illness, because individual autonomy and client-centredness play an important role with these clients. In the current study we use the terms client and nurse.

\section{DESIGN}

A qualitative research method was chosen because little is known about the experiences of nurses with respect to client-centred care. Grounded theory approach was chosen because this approach provides strategies for developing concepts and theories that fit into a particular field of practice. This may contribute to the use of recommendations of the study by professionals (May, 1990; Strauss \& Corbin, 1998). Methods used (see Table 1), were participatory observations (with 8 nurses visiting 45 clients) and additional semi-structured interviews (with 7 of the nurses observed, and with 2 nurses without previous participatory observation). Data collection was based upon theoretical sampling. This means that through the selection of particular nurse and client circumstances, the phenomenon of nurses' experiences with client-centred care was explored (see section sample). According to Denzin and Lincoln (2003), triangulation (deploying different methods) can be seen as an alternative to validation. This study used a combination of participatory observations and semi-structured interviews to add rigor, breadth, complexity, richness and depth to the inquiry, and to secure content validity (Sim \& Sharp 1998). 
Table 1. Methods and Sample Characteristics Related to the Analysis Phases

$\begin{array}{lccc} & \text { Open coding } & \text { Axial coding } & \text { Selective coding } \\ \text { Total number nurses involved } & 4 & 3 & 3 \\ \text { Nurses observed } & 4 & 2 & 2 \\ \text { Situations observed } & 23 & 12 & 10 \\ \text { Semi-structured interviews } & 3 & 3 & 3 \\ \text { Education level } & & & \\ \text { Registred Nurse (RN) bachelor's degree } & 3 & 2 & 1 \\ \text { RN } & - & - & 2 \\ \text { Auxiliary nurse } & 1 & 1 & - \\ \text { Number of nurses per organization } & & & 2 \\ \text { Organization A } & 3 & 1 & - \\ \text { Organization B } & 1 & 1 & 1 \\ \text { Organization C } & - & 1 & \end{array}$

\section{SAMPLE}

The total sample consisted of ten nurses of the Department of Nursing and Caring of three home-care organizations in the south of the Netherlands (see Table 1). Managers of the nurses were given an oral presentation and written information about the aims and design of the research project. Guided by instructions concerning the variety in the contexts of the observations (education, work experience, age, sex, specialization, shift), nurses were asked by their managers to participate. The selection of nurses resulted in variations in education (six registered community nurses with Bachelor's degree, two registered nurses (RN), and two auxiliary community nurses). All nurses were the primary nurse of several clients visited, except for one nurse who provided evening care only; five nurses had a particular specialization; the age of the nurses observed ranged from 25 to 50 years; work experience ranged from 0 to 27 years. Half of them worked mainly in villages, the others mainly in towns. All nurses worked in both middle- and working-class neighbourhoods; one male nurse participated in the study.

The selection of clients was linked to the planned route of the nurse. The route was partly guided by chance and partly guided by the researcher's preferences in advance. Preferences resulted in variations with respect to medical diagnosis (e.g., cardiovascular disorders, neurologic disorders, respiratory disorders, metabolic and endocrine disorders, neoplastic disorders) and variety with respect to phases of their illnesses (onset of disease, stable phase, transitional phase), self-assertiveness, cognitive abilities, experience-based knowledge, gender and age. 


\section{METHOD}

\section{Data collection}

Data were collected between November 2002 and June 2003. During seven days, participatory observations were undertaken to get close to the situations as they occurred in the actual setting. In order to disrupt the care-process as little as possible, it was agreed that the researcher (being a nurse) would participate in the care process if the nurse observed so requested. This meant for example passing things, assisting with wound care or with hygienic care. The observations were loosely structured by an observation scheme with the following topics: nurse's role, client's role, responsibilities, experienced barriers and factors facilitating client-centred care. Each visit lasted between 20 minutes and 2 hours. The additional semi-structured interviews were held in order to explore the following topics more deeply: perspective on client-centred care, nurse role, client role, experienced barriers and factors facilitating client-centred care.

\section{Ethical considerations}

The nurses received copies of the informed consent procedure for clients and written points of attention for the participatory observation, (e.g., anonymity, role of the researcher). Managers did not have access to individual participants' responses. The nurse gave clients written information about the research project (aim, privacy, request for consent) in a letter, signed by the manager at least one day before the participatory observation. Clients could give consent to the nurse in advance. Only clients who gave consent in advance were visited. In addition, at the start of the home-care visit, the researcher checked if the client had been informed, and asked again for permission to enter the client's home. The research project was discussed with a member of the Central Committee on Research involving Human Subjects (CCMO), leading to the conclusion that further approval from an Ethics Committee was not necessary.

\section{Data analysis}

Participatory observations were written down in reports afterwards. Interviews were recorded and transcribed. All data were imported into Kwalitan 5.0. (Peters, 2000). Methodological, analytical and theoretical memos were made. Three researchers, one being a senior-researcher, were involved in the coding process. All data were coded independently by at least two different researchers. Meetings were held to discuss the differences in codes given, so that the analysis could be broadened with new insights. Analysis took place simultaneously with the data collection. 
To obtain a broad variety of ideas, open coding was applied to the data from four nurses (see Table 1). Categories chosen, to organize the results, were based upon the views of the participants. Through comparative analysis (thinking about properties and dimensions of categories by grouping together similar events), roles, responsibilities involved and tensions could be identified. After analyzing participatory observations and interviews of two nurses and one auxiliary nurse, we considered to have an overview of the most relevant properties and dimensions. Analysis of the data of the fourth nurse provided no substantial new data. Relationships between concepts were already emerging. Tensions experienced by the nurse with respect to giving client-centred care in practice emerged as a main category. The categories 'roles', 'responsibilities', 'tensions' and subcategories were organized into a framework that served as the basis for axial coding. Axial coding was applied to new data from three nurses (see Table 1). The aim was to further explore the variety within the categories found. Nurses perceived some of the responsibilities as competing. In this phase, the core category 'competing responsibilities' was identified. Because the present study is aimed at perceptions with respect to client-centred care, the analysis focused on responsibilities competing with the role and responsibilities as a responsive professional towards the client demand. Hence, mutual tension fields between the other roles and responsibilities were not explored further. Furthermore, responsibilities towards the family caregiver and towards other health care workers were excluded. Based upon a comparison of how nurses dealt with competing responsibilities, strategies could be identified. Coding for process, a technique aimed at tracing interactions and changes over time, helped to identify conditions and consequences related to the respective strategies, and to identify relations between the categories and subcategories generated. After analysis of half of the situations observed and two of the interviews, analysis provided no new concepts and relationships between concepts. A few codes were added with respect to the properties and dimensions identified earlier. Selective coding was applied to new data of three nurses (see Table 1). These data did not change the emerging pattern in the analyses. It was concluded that saturation was reached. The concepts found and their relations were compared with related concepts in the literature (Boeije, 2002; Strauss \& Corbin, 1998).

\section{RESULTS}

\section{Roles and responsibilities}

An inventory of the nurses' perceptions with respect to client-centred everyday care revealed five roles and accompanying responsibilities from the nurse's perspective. First, these roles and responsibilities will be described, then, 
competing responsibilities will be discussed. Illustrative scenes of the observations and interviews are integrated in the discussion of competing responsibilities. Responsive professional. The role as responsive professional is about meeting the client's demand. This responsibility encompasses respect for client autonomy (having the possibility to live their lives consistent with their life stories); presence (being there for the client if needed), continuity of life (the moment that care is needed and amount of care needed) and uniqueness (understanding the client as an individual human being ).

Critical professional. The role as critical professional encompasses giving and grounding a professional opinion and setting professional boundaries. In this role the nurse is responsible for effective care, solving and preventing health-related problems, fairness in dividing time over clients, and acting within professional responsibilities.

Developer of client competencies. The role as developer of client competencies concerns facilitating and developing client autonomy and participation. Furthermore, in this role nurses feel responsible for beneficence (not honouring client wishes if they are deemed irrational or against the client's best interest) and caring about clients with impaired competencies to participate in care.

Individual. In the role as individual, nurses feel responsible for keeping individual distance and privacy, continuation of their own family life and health (e.g. preventing back injuries).

Employee. Finally, the role as employee of the care organization encompasses responsibility for efficiency (obtaining desired effects without waste), productivity (making declarable care hours) and cost containment.

\section{Competing responsibilities}

Nurses perceived several of the responsibilities identified as competing. The core category 'competing responsibilities' is defined as responsibilities that compete with the responsibility as a responsive professional. More than one course of action is possible, but choosing the responsibilities attendant with the role as a responsive professional competes with the other roles and responsibilities and vice versa. Figure 1 visualizes the competing responsibilities that were identified between the role as responsive professional on the left-hand side, and the roles as critical professional, developer of client competencies, individual, and employee on the right-hand side.

In the next sections, four categories of possible competing responsibilities will be discussed (see Table 2). 


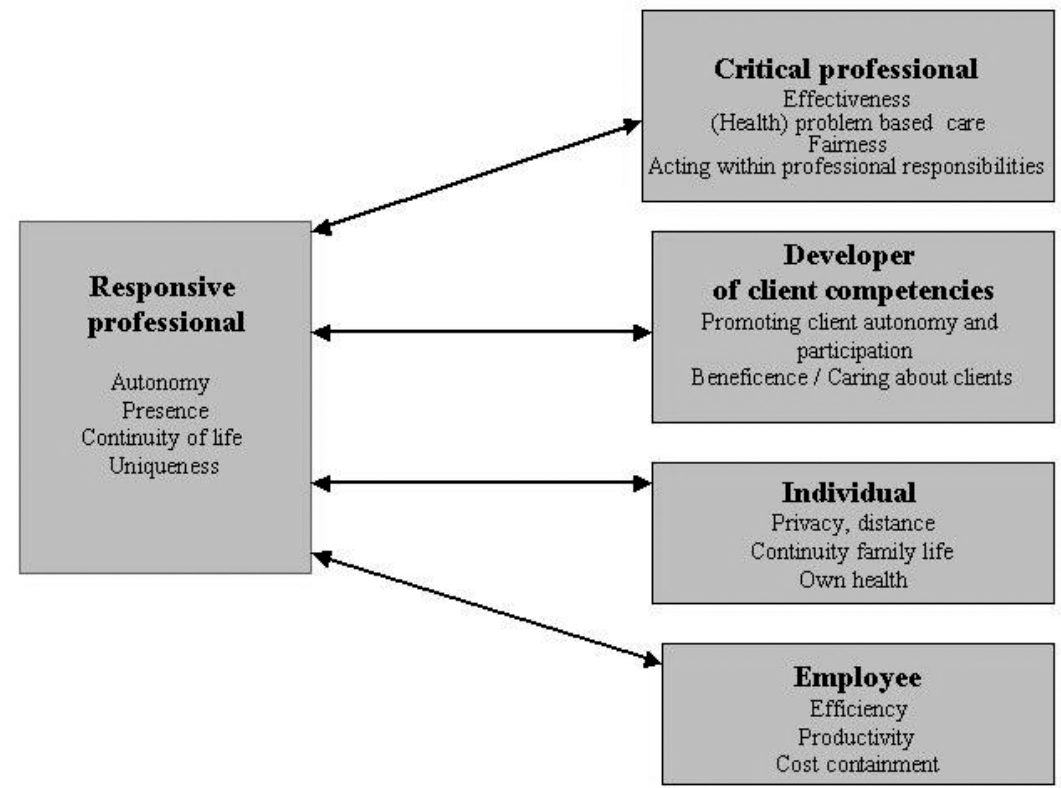

Figure 1. Roles and responsibilities competing with the role as a responsive professional

Table 2. Possible Competing Responsibilities

\section{Responsive professional versus critical professional}

Meeting the client demand (autonomy) and evidence-based practice (effectiveness) Short-term client choices (continuity of life) and preventing long-term problems (problem-based care) Presence needed with one client implies being late with other clients (fairness)

Demanding clients and fairness with respect to less demanding clients

Client wishes go beyond nursing professional responsibilities

\section{Responsive professional versus developer of client competencies}

Clients not motivated for care (autonomy) and a signalled need for care (beneficence)

Meeting the client's demand (autonomy) and promoting independence

\section{Responsive professional versus individual}

Meeting the client's demand (presence) and the nurse's privacy (distance)

Meeting the client's demand (continuity of life, uniqueness) and continuity of the nurse's family life Meeting the client's demand (continuity of life) and preventing own back-injuries (health)

\section{Responsive professional versus employee}

Meeting the client's demand (continuity of life, uniqueness, presence) and production Meeting the client's demand (continuity of life, uniqueness, presence) and efficiency Care about the client's and having to charge the costs Meeting the client's demand and cost containment 
Being a responsive professional versus being a critical professional. Competing responsibilities were noted if respect for client autonomy was competing with choosing evidence-based interventions (effectiveness).

The client wants the nurse to make the compressive bandages less tight. In the client's perspective, that is better for her legs. Based upon her professional knowledge, the nurse states that the function of the compressive bandages technique is the pressure obtained by the bandages.

After a bladder washout, the woman expresses a wish to close the catheter. She's expecting visitors in the afternoon. The nurse states that this is in conflict with risks of infection. She says, "You know I cannot agree with this" ...

Other competing responsibilities in this category concern client (short-term) choices for continuity of their living situation and the nurses' intention to prevent and treat long-term (future) problems:

Two elderly sisters, living isolated on a farm, are at risk of serious injury because of their disabilities. The nurse proposes a change in their living situation. The sisters want to continue their living situation. The nurse is really worried about this situation.

Presence (being with the client) if the client's condition suddenly aggravated, or when the client was anxious or sad, often meant being too late or in a hurry with the subsequent clients. In these situations availability for the client competed with fairness in spending time with other clients. Respecting autonomy and fairness were at stake with very demanding clients in the nurses' perception: clients asking more help than was necessary in the nurses' perspective. Finally, sometimes client wishes went beyond professional responsibilities as perceived by the nurse: Clients asking to put the rubbish outside; to clean the bathroom, to take the laundry to the launderette; to take the dog for a walk.

Being a responsive professional versus being a developer of client competencies. Respect for the client autonomy competed with beneficence if clients were not aware of their care demand. This was seen with impaired client competencies related to coping processes, or impaired cognitive capacities. Some of these clients were not able to express their demand in the right way, at the right place.

A young diabetic does not comply with the therapeutic guidelines. "Insulin is what he wants, instead of oral medication, because he thinks he can eat and drink then whatever he wants. If I would agree, he risks an amputation of a leg in ten years from now ..."

This category concerned also respecting client autonomy versus promoting independence, and not taking over something the client can do by him- or herself. 
Some clients are able to take over a part of their care. But that is so hard sometimes. It seems as if they refuse to understand why we think it is important that they participate in care

Being a responsive professional versus being an individual. This category encompasses the nurses' need for privacy and a private life competing with the clients' desire for the nurse to be there (presence). Several nurses report tensions between involvement and individual distance.

I feel very comfortable with clients at home. That can be a drawback, that you start feeling too close. You have to watch out for that, that things don't get out of hand. Then things become too personal, and clients ask you for more than they really need ... So we had a client and he knew my father. He needed to go to the hospital. He called me at home at night.

This category also covers the clients' desire to keep their living situation unchanged and the prevention of back-injuries (health) with the nurse.

Two elderly sisters are living on their own on a farm. One of the sisters is no longer adequately mobile. An adjustable bed is needed in order to prevent the nurses getting back injuries. This means, however, that the sisters can no longer sleep together, as they had done from childhood.

Being a responsive professional versus being an employee. In all care organizations competing responsibilities were seen between responsiveness to the client demand and the need for production ('making care-hours'), efficiency (not wasting time as a result of central planning system of care), multi-availability of nurses and having to stay within financial reimbursements of the needs assessment organization. These responsibilities competed with availability for the client (presence), continuity of the life of the client, and with uniqueness (individual attention).

A man wants the nurse to come before $10.00 \mathrm{a} . \mathrm{m}$. in order to help him take a shower. The nurse says she certainly cannot guarantee that, she has other clients to visit at that time.

An evening-care nurse encounters a conflict in making an efficient route: 'I cannot make a detour of $10 \mathrm{~km}$ because the client wishes me to!'

Having to charge costs (co-payments) to the client competed with caring about the client. Nurses experienced difficulties in charging costs for a preventive home visit, charging costs related to time spent while drinking coffee, and charging costs related to planning and documentation. Difficulties were experienced in particular, if the nurse knew that the client had not much money to spend. 
Sometimes I run up against the limits in giving the care needed. For example in home visits with the partner in mourning. The partner is left alone. From a certain moment, the costs of these visits are no longer reimbursed. The client has to pay for these visits. I find this very difficult. It feels as if you have to sell yourself, and we are not educated to do so. You are expected to behave business-like.

I had a young woman with onset dystrophy. She was the mother of four young children. The family had many expenses. And when we had been giving care for a few months, they received the bill, and then she said she preferred to go a step back, her husband had to take over. While her husband already has so much trouble. That makes me cry.

Finally, this category contains disagreements with decisions of the needs assessment organization. In these situations client values versus cost containment efforts were at stake.

The assessors of the needs assessment organization (...) Sometimes you know from the start you're not going to manage it within the care hours indicated... And then the bureaucracy, that goes against the grain with me. All the forms that have to be filled in ... while the organization is pushing for production, production ... The time needed concerns indirect care hours and the organization gets less money for that kind of activities. Moreover, I need to use the client-number, and so I have to tell the client that extra hours will be charged

\section{Strategies, conditions and consequences}

We identified four strategies in dealing with the competing responsibilities: pleasing, dialoguing, directing, and detaching. A strategy is defined as a course of action to deal with the competing responsibilities. Two of the strategies identified (directing and detaching) were also used as second choice strategies, that is a strategy deliberately chosen, but that is not the course of action preferred by the nurse in general. Although we could identify more than one strategy in the nurses observed, each nurse seemed to have a main strategy.

Three conditions were identified, or not identified, related to applying a certain strategy: awareness, responsibility taking, and commitment with the client demand (see Figure 2). Awareness is defined as recognition of the competing roles and responsibilities. This implies recognition of the client demand and awareness of the consequences of the course of action on behalf of the client. Responsibility taking is defined as consciously and actively taking a position with respect to choices and decisions, based upon assertiveness, decisional autonomy and freedom of the nurse. Nurses not taking responsibility leave decision making to 


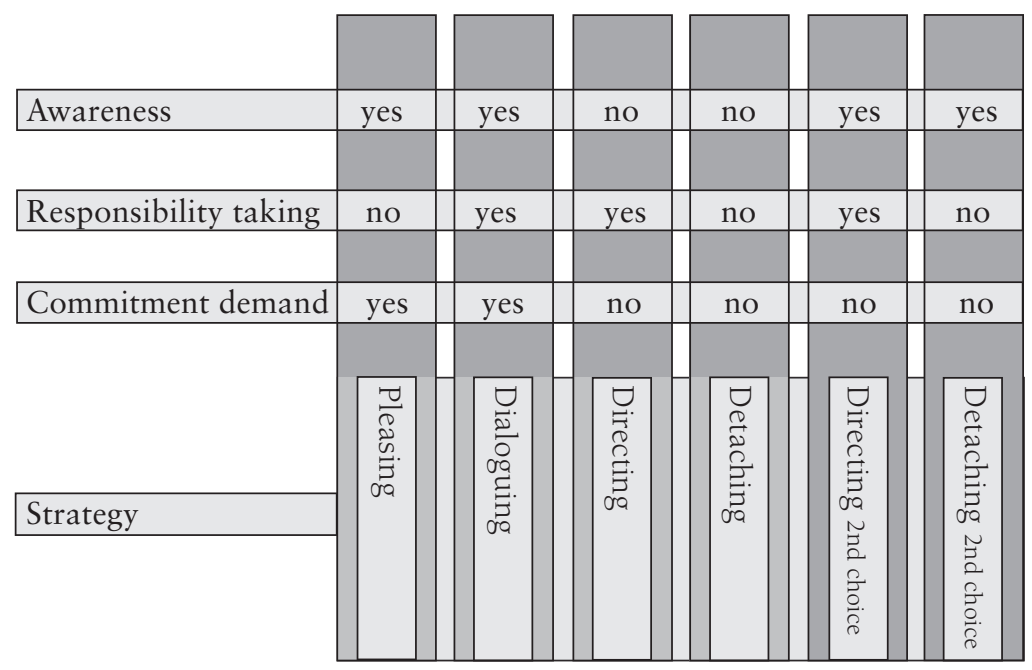

Figure 2. Strategies of nurses in dealing with competing responsibilities, and conditions identified related to the respective strategy.

Yes $=$ Condition was identified

No $=$ Condition was not identified.

others. They execute decisions made by others and seem to avoid conflicts. Commitment to the client demand concerns setting priority to 'responsiveness to the client demand'. In contrast, priority is given to the role as a critical professional, to the role as a developer of client competencies or to the role as an employee. Figure 2 shows the strategies and the conditions identified and not identified related to these strategies.

Finally, strategies could be characterized by some consequences: feelings experienced by the nurses. Conditions and consequences are integrated in the next discussion of the strategies.

Pleasing. Nurses demonstrating 'pleasing' are aware of the competing responsibilities, are committed to the client demand, but lack responsibility taking for the competing responsibilities. It is the client who determines the course of action. Conflicts were avoided. In the eyes of their colleagues, these nurses "do everything for the client, sometimes even if they are not capable of doing it". These nurses seemed to act impulsively, with little rational deliberation. Some nurses gave help outside their working hours and beyond professional responsibilities, sometimes without telling their colleagues or manager and without reporting, so costs were not charged to the client. 
I had to visit a demented woman. She asked me to go and get some French fries. I can understand that the French fries were very important to her at that very moment, but to be honest, I think that goes too far ... but, when the woman said OK, then I will ask someone in the street, I felt guilty, and I did as she asked.

The client asks if the nurse could come earlier the next morning because of a visit to the specialist. The nurse promises she will be there at $7.00 \mathrm{a} . \mathrm{m}$. Later the nurse tells, she usually only starts at $8.00 \mathrm{a} . \mathrm{m}$. She has two young children.

Nurses adopting this strategy seemed sub-assertive. Pleasing was reported to be related to feeling guilty if they did not meet the client demand.

Dialoguing. Nurses demonstrating 'dialoguing' are aware of competing responsibilities and take responsibility together with the client. Commitment with the client demand concerns a process of actively signalling, discussing and negotiating with the client, and actively searching for compromises, or creative solutions, sometimes at organizational level. Nurses reported having to be very patient sometimes. Dialoguing included giving and grounding a professional opinion, even if the client did not agree, and respecting the client's point of view. Professional and personal boundaries are made clear.

A client with Parkinson's disease needs to be transferred twice a day between the bed and the wheelchair. "A patient lift is available, but there is a high pile carpet, which is a contra-indication for the use of that lift, because of the physical strength needed. At the moment we are discussing the problem with the client. We explained the problem carefully. A simple solution should be a piece of cheap linoleum. For the client it's really an issue. If they continue to refuse to change, we will respect their choice, but we can't continue our visits."

I once had a client, a manager, he was used to ordering people and so he ordered us to wash him, but he really could do that partly by himself. In the beginning I tried very hard to stimulate him to do that by himself, but it made him very angry. We negotiated and in the end, he was willing to comb his hair. From that moment, the tension had gone. I think that you have to accept that sometimes you have to take another course.

Dialoguing is associated with nurses being assertive and developing their professional knowledge through reflection. They frequently have students and trainees. Nurses mentioned a primary care nurse system and a decentralized planning system, management support, structural feedback and reflection with colleagues as facilitating factors. Nurses showing a dialogue mentioned experiencing plea- 
sure in their work, provided that the client was ready to participate. They felt selfconfident.

Directing. Nurses demonstrating 'directing' showed little awareness of competing responsibilities, and hence of the client's vulnerable situation, and of the consequences of their decisions on behalf of the client. They take responsibility for care decisions. Directing lacks commitment with the client demand. The nurse seems to act 'dominantly' and not to be seriously considering the possibility of choosing another course of action.

After bathing, an elderly woman shows she has difficulties in putting on her stockings and shoes. The nurse says she has to do that by herself, because it is important for her to stay as independent as possible. The woman falls silent and does as she is told.

I had very much trouble in reducing care with a woman with limited mobility related to a fractured hip. The woman insisted on help with showering each day. She argued that she has obtained permission by the central assessor. I did not agree. The woman was able to shower without help. She only needed help with her underwear. I finally succeeded in cutting down care by saying: Do you really think we can come each day to put on your underwear? Moreover, I related to the client that I'd discuss the matter with the General Practitioner.

This strategy was seen in nurses who put their professional values above the client's values.

They took responsibility and seemed convinced that they did the right thing. Reflection seems poor: they do talk about conflicting demands, but the emphasis is on seeking affirmation of their behaviour from their colleagues.

Detaching. Nurses demonstrating detaching, dissociate oneself from the client needs and wishes, and attach oneself to rules and regulations. These nurses seem not aware of competing responsibilities, and of the client's demand and do not take responsibility for care decisions. Detaching lacks commitment with the client demand. The emphasis is on orientation to the task (e.g., work schemes, protocols, routines, centrally planned routes), and on care indications as stated by the central assessor. The values 'efficiency' and 'production' prevail over individual client interests, 'the work has to be done'. Some rules were stated by the organization, or by others, such as labour conditions, medical prescriptions, and conditional resources. Furthermore, nurses stuck to shared informal rules such as rules concerning allowance of early morning help.

A client asks the nurse to come earlier the next day. The client has an early appointment with the hairdresser. The nurse is not willing to come earlier 
only for a visit to the hairdresser. She does not ask for background details. "If we start doing so, we have to do that for all clients ..."

Auxiliary nurse: "Clients should not force me to do things, I really have very much trouble with that. And if it is not indicated by the central needs assessor, I refuse to do it too. People tend to ask things like 'Could you just put the garbage in the shed?' I tell them honestly: this is not indicated and that's not my task".

Detaching was seen more frequently if the visiting nurse was not the nurse responsible for the care plan or if the responsibility for the care plan was shared with another nurse, in close collaboration with General Practitioners, and with very demanding clients.

Directing (as second choice). Nurses using directing as second choice show awareness of the client's demand, however, they are deliberately not committed to the client demand, because of the client's impaired competencies to participate in care as perceived by the nurse (due to coping processes, stroke, illness or dementia). Through this strategy nurses took responsibility and were acting dominantly out of beneficence, because client wishes were judged irrational or against the client's best interest.

An old lady who feels she has fever and diarrhoea related to an intestinal infection does not want to spend money on an ear-thermometer. The nurse thinks the use of a rectal thermometer is not appropriate for hygienic reasons. The nurse thinks it is difficult to accept the client's decision. She asks the sister-inlaw to buy an ear-thermometer. Later she tells the client she asked the person to do so for her.

The family of a dementing woman wants her to stay at home. The woman has diabetes and is very aggressive. Two persons are needed to take care of her. "Everything is very threatening to her. A colleague needs to hold her while I inject her. Really awful. Yes, how far do you go in doing things against the client wishes? ... but when we don't do that, she'll die."

In these situations, nurses experienced an ethical dilemma. They felt confident about their decision, however, and reflected on their actions.

Detaching (as second choice). In contrast with detaching as first-choice strategy, nurses using detaching as second choice were aware of the vulnerable position of the client and recognized their demand, but could not take responsibility because they experienced organizational barriers (such as bureaucratic rules, too heavy a workload, efficiency measures, high staff turnover). As a result, there was no commitment with the client demand. 
"Some colleagues find it very hard to come late to a client, particularly when the client gets angry. If a client behaves that way, I tell them I can understand that it is really embarrassing, but that I can't help it."

For prevention and guidance a central needs assessment is required. I see that as a very big tension field. You need to base your request on solid facts and that's difficult ... You should be allowed to visit clients without making it immediately a question of money, because to me that is embarrassing. I try to provide the information needed, but I really have a problem with it.

With this strategy, nurses experienced frustrations and ethical distress: they knew the right course of action, but conditions in the home care organization were perceived as barriers to acting in that way.

\section{DISCUSSION}

In the nurses' perception, in giving everyday client-centred care, they are confronted by responsibilities as a responsive professional to the client demand on the one hand, and responsibilities as critical professional, developer of client competencies, individual person, and employee on the other. The core category 'competing responsibilities' was identified: responsibilities competing with the responsibility as a responsive professional. Four strategies in balancing between competing responsibilities were identified: pleasing (acting in accordance with the client's demand), dialoguing (sharing responsibility for care with the client), directing (acting according to the professional's responsibilities), and detaching (orientation to the task). Two of the strategies identified were used as secondchoice strategy, a strategy deliberately chosen, that is not the course of action preferred by the nurse in general: directing as second choice (soft paternalism due to impaired client competencies), and detaching as second choice (orientation to the task, due to organizational barriers). All strategies are characterized by three conditions identified or not identified related to performing the strategy: awareness of the client demand and of competing responsibilities, responsibility taking and commitment with the client demand. Finally, the strategies could be characterized by consequences: feelings experienced by the nurses, ranging from work satisfaction to guilt and moral distress. Although performing more than one strategy, each nurse seemed to have one main one.

Client-centred care emerges from the present study as effectively balancing between competing responsibilities. The question raises which strategies can be characterized as 'effective'. Dialoguing emerges as a strategy of finding a balance between competing responsibilities, in which all three conditions are identified (see Figure 2). Nurses are aware of, and take responsibility for competing responsibilities. Commitment with the client demand manifests in this strategy as a 
negotiating process. Work satisfaction was reported. Nurses performing a pleasing strategy, are also committed to the client demand, and aware of competing responsibilities, but on the contrary, seem not to take responsibility for competing responsibilities. Pleasing includes a risk of doing something that is against the client's best interests. Furthermore, feelings of guilt were reported. This cannot be defined as an effective balance. Directing as second choice, however, emerges also as a strategy in which nurses deal effectively with competing responsibilities. In this strategy, nurses are aware of, and take responsibility for competing responsibilities, but the client demand is not honoured because it is deemed irrational or against the client's best interest. Not the client demand, but client interests are central. One-sided decisions for the client justified by reasons referring to the welfare of the client, and justified by impaired client competencies to take decisions, are described in literature as soft paternalism (ten Have, ter Meulen \& van Leeuwen, 2003). The finding that clientcentred care is not always the same as meeting the client demand, is supported in the literature (Tonkens, 2003; Schoot, Proot, ter Meulen \& de Witte 2005a). Awareness of competing responsibilities and responsibility taking emerge as important conditions for client-centred care. The concept of awareness is closely related to the concept of recognition of client values (Schoot, Proot, ter Meulen, \& de Witte, 2005b). Awareness as described in the present study is in line with moral sensitiveness as described by Lutzen, Cronqvist, Magnusson and Andersson (2003). Van der Arend \& Remmers-van den Hurk, (1999) affirm the finding that some Dutch nurses have limited awareness of the moral dimensions of their practice. Some nurses, who were aware of the client demand, did not take responsibility for competing responsibilities. Responsibility taking concerns actively taking a position with respect to competing responsibilities based upon decisional freedom and autonomy. These nurses either lacked assertiveness (pleasing), or did not feel free to choose the right course of action, because of long-term organizational barriers (detaching as second choice). Nurses applying detaching as second choice experienced moral distress. The concept of moral distress in the nursing context has also been described in the literature as painful feelings and/or psychological disequilibrium that occurs when nurses are conscious of the ethically appropriate action in a particular situation, but cannot carry out that action because of organizational conditions (Corley, 2002; Jameton, 1993). Corley states that (moral) autonomy of the nurse (freedom, right and responsibility to make choices) with respect to care decisions and care planning needs more attention in order to prevent moral distress (Corley, 2002). Vulto (2002) points to absence due to illness as a result of organizational barriers. Several factors influencing the experience of ethical distress in nurses (such as lack of time, lack of support, legal limits, institutional policy), are described in the literature (Burger, Erlen, \& Tesone, 1992; Corley, 2002; Raines, 2000; Van der Arend \& 
Remmers-van den Hurk, 1999). It is difficult, however, to compare these findings with the present study, because of differences in the scope and context of the studies, either not concerning 'everyday care' dilemmas, or restriction to a specific field, such as oncology.

Effectively balancing between competing responsibilities emerges from the present study as awareness of competing responsibilities, taking responsibility, and putting the client interests central. The strategies dialoguing and directing as second choice seem to fit with this description. 'Awareness' and 'responsibility taking', are very close to Tronto's (1994) ethical elements of care 'attentiveness' and 'responsibility'.

\section{Strengths and weaknesses}

The trustworthiness of the study can be evaluated based upon the criteria: credibility, transferability, dependability and confirmability (Lincoln \& Guba, 1985, Strauss \& Corbin 1998; Van der Lyke \& Proot, 2004). Credibility was given attention by two different methods for data collection (participatory observations and semi-structured interviews), peer debriefing with other researchers involved, and the use of codes as close to the data as possible. Transferability of findings was given attention by purposefully sampling a variety of clients, nurses and homecare organizations. Dependability and confirmability were given attention by triangulation of researchers. All data were coded independently by two of the researchers involved, and discussed next. Additionally, insight in the research process was given by describing comprehensively the steps taken, the findings and the relationships found. Unintended, the emphasis in the study is on experiences and perceptions of nurses with a Bachelor's degree. Only two registered nurses and two auxiliary nurses participated in the study. Additional sampling of auxiliary nurses during the selective coding phase, would have given more strength to the results with respect to this particular subgroup. Only one male nurse participated in the study. The home care organizations selected were restricted to the south of the Netherlands. A qualitative design like grounded theory is an adequate design to explore and describe an unknown phenomenon, such as client-centred care. It is not an adequate design, however, to test for significant differences between client groups, or nurses with specific characteristics or for differences between care organizations.

\section{Application}

Client-centred care with chronically ill clients receiving home care is a complex process, influenced by the context of the care situation. A universal approach in dealing with competing responsibilities is not possible. Several recommendations can be made in order to find a balance between competing responsibilities. 
Critical ethical reflection. Critical ethical reflection in dialogue with colleagues and the manager is recommended, particularly for nurses who adopt the strategies 'directing' or 'detaching' frequently. This will contribute to awareness of roles and responsibilities, and of consequences of the course of action on behalf of the client. Participation of the manager is recommended to provide nurses with support.

Development of the care relationship. It is recommended to develop a care relationship with the client characterized by mutual respect and involvement. Therefore, knowing the client, the client demand and the context of the client situation is required.

Being a critical partner in dialogue. Balancing between competing responsibilities is not doing non-critically as the client wants. Being a critical, but creative and flexible professional is required. It is recommended to dialogue and negotiate with the client with respect to the client demand and competing responsibilities. Competence development with respect to communication skills and negotiation skills is recommended. Development of self-assertiveness is recommended for nurses performing the strategy pleasing frequently. This will contribute to responsibility taking.

Providing conditions for the care relationship. Policy makers are recommended to provide conditions aimed at developing and sustaining a care relationship, such as sufficient time, a primary nurse system, decentral planning. This will prevent organizational barriers in finding a balance.

Improvement of professional autonomy. Policy makers are recommended to improve professional autonomy in general, and particularly for nurses frequently adopting the strategy 'detaching as second choice'.

Further research. Further research into strategies performed by auxiliary nurses and related conditions, into the impact of competence development in nurses, and into the effects of a supportive organization, is recommended.

\section{ACKNOWLEDGEMENT}

The authors gratefully acknowledge all nurses and auxiliary nurses, their clients, and their managers involved in the study for their help. The study was financially supported by Zuyd University. 


\section{REFERENCES}

Boeije, H. R. (2002). A purposeful approach to the constant comparative method in the analysis of qualitative interviews. Quality \& Quantity, 36, 391-409.

Burger, A. M., Erlen, J. A., \& Tesone, L. (1992). Factors influencing ethical decision making in the home setting. Home Healthcare Nurse, 10(2), 16-20.

Cahill, J. (1998). Patient participation: A review of the literature. Journal of Clinical Nursing, 7, $119-128$.

Chewning, B., \& Sleath, B. (1996). Medication decision-making and management: A clientcentred model. Social Science and Medicine, 42, 389-398.

Corley, M. C. (2002). Nurse moral distress: A proposed theory and research agenda. Nursing Ethics, 9, 636-650.

de Klaver, P. M., \& Scholten, C. (2002). De vraag naar thuiszorg: Literatuurstudie naar voorbeelden van (meer) vraaggestuurde thuiszorg (The demand for home care: A literature study concerning examples of (improved) client-centred home care). Leiden, the Netherlands: SWOKA.

Denzin, N. K., \& Lincoln, Y. S. (Eds.), (2003). Collecting and interpreting qualitative materials (2nd ed.), Thousand Oaks, CA: Sage.

Elander, G., Dreschler, K., \& Persson, W. K. (1993). Ethical dilemmas in long-term care settings; Interviews with nurses in Sweden and England. International Journal of Nursing Studies, 30, 91-97.

Elwyn, G. (2001). Shared decision making: Patient involvement in clinical practice, Thesis. Nijmegen: Katholieke Universiteit Nijmegen, the Netherlands.

Jameton, A. (1993). Dilemmas of moral distress: moral responsibility and nursing practice. AWHONNS Clinical Issues of Perinatal Womans Health Nursing, 4, 542-541.

Jewell, S.E. (1994). Patient participation: What does it mean to nurses? Journal of Advanced Nursing, 19, 433-438.

Lincoln, Y., \& Guba, E. G. (1985). Naturalistic inquiry. Newbury Park CA: Sage.

Lutzen, K., Cronqvist, A., Magnusson, A., \& Andersson, L. (2003). Moral stress: synthesis of a concept. Nursing Ethics, 10, 312-322.

May, C. (1990). Research on nurse-patient relationships: problems of theory, problems of practice. Journal of Advanced Nursing 15, 307-315.

NRV, [National Council for Public Health] (1989). Discussienota Thuiszorg (Discussion paper on Home care). Zoetermeer, the Netherlands: National Council for Public Health.

Nu'91/LCVV, [Vocational Organization for Nursing and Care / National Centre for Nursing and Care] (1998). Beroepscode voor de verpleging (Professional Code for Nursing Practice). Maarssen, the Netherlands: Elsevier gezondheidszorg.

Peters, V. (2000). Kwalitan 5.0: Gebruikershandleiding (Kwalitan 5.0: User Manual). Nijmegen, the Netherlands: Katholieke Universiteit Nijmegen.

Raines, M. L. (2000). Ethical decision making in nurses. Relationships among moral reasoning, coping style and ethics stress. JONA's Healthcare, Law ,Ethics and Regulation, 2, 29-41.

RVZ, [Council for Public Health] (1998). Naar een meer vraaggerichte zorg (Towards increased demand-orientedness). Zoetermeer: the Netherlands, Raad voor de Volksgezondheid. 
Sainio, C., Lauri, S., \& Ericksson, E. (2001). Cancer patients' views and experiences of participation in care and decision making. Nursing Ethics, 8, 97-113.

Schoot, T., Proot, I., ter Meulen, R., \& de Witte, L. (2005a). Actual Interaction and clientcentredness in home-care. Clinical Nursing Research, 14 (4), 370-393.

Schoot, T., Proot, I., ter Meulen, R., \& de Witte, L. (2005b). Recognition of client values as a basis for tailored care: the view of Dutch expert patients and family caregivers. Scandinavian Journal of Caring Sciences, 19, 169-176.

Sim, J., \& Sharp, K. (1998). A critical appraisal of the role of triangulation in nursing research. International Journal of Nursing Studies, 35, 23-31.

STOOM. (2002). Thuiszorg op zoek naar de gunst van de klant (Home care looking for the client's favour). Bunnik, the Netherlands: SWOKA/Research voor Beleid /Stoom.

Strauss, A. L., \& Corbin, J. (1998). Basics of Qualitative Research. Techniques and Procedures for Developing Grounded Theory. Thousand Oaks: Sage Publications.

ten Have, H. A. M. J., ter Meulen, R. H. J. \& van Leeuwen, E. (2003) Medische ethiek (Medical ethics), Bohn Stafleu Van Loghum, Houten.

Terpstra, E. (1997). Beleidsmatige dilemma's bij de vormgeving van vraaggestuurde zorg. In L. Boon (Ed.), Vraaggestuurde zorg (Demand-driven care) (pp. 7-13). Amstelveen, the Netherlands: Stichting Sympoz.

Tonkens, E. (2003). Mondige burgers, getemde professionals. Marktwerking, vraagsturing en professionaliteit in de publieke sector (Empowered citizens and tamed professionals: the market, demand-driven care and professionalism in the public sector). Utrecht, the Netherlands:the Netherlands Institute for Care and Welfare (NIZW).

Tronto, J. C. (1994). Moral boundaries: A political argument for an ethic of care. New York: Routledge.

Van den Bos, G. A. M., Frijling, B. W., Koster-Dreese, Y., Schnabel, P., \& Spreeuwenberg, C. (Eds.). (1999). Chronisch-ziekenbeleid in de jaren negentig (Health care Policy for the chronically ill in the nineties. Utrecht, the Netherlands: Uitgeverij SWP.

Van der Arend, A., \& Remmers-van den Hurk, C. H. (1999). Moral problems among Dutch nurses: a survey. Nursing Ethics, 6(6), 468-482.

Van der Kraan, W. G. M. (2001). Vraaggericht en vraaggestuurd: Een literatuuronderzoek naar vraaggerichtheid en vraagsturing in de gezondheidszorg (Demand-oriented and demand-driven. A review of the literature into demand-oriented and demand-driven care in the health-care sector). The Hague: ZONMw en Erasmus Universiteit Rotterdam.

Van Rooij, E., Droyan Kodner, L., Rijsemus, T., \& Schrijvers, G. (Eds.). (2002). Health and health care in the Netherlands. A critical self-assessment of Dutch experts in medical and health sciences (2nd revised edition ed.). Maarssen: Esevier Gezondheidszorg.

Van der Lyke, S., \& Proot, I. (2004). Kwalitatief onderzoek: over stromingen, kwaliteit en praktische relevantie (Qualitative research : trends, quality and practical relevance). In K. Cox, D. de Louw, J. Verhoef \& C. Kuiper (Eds.), Evidence-Based Practice voor Verpleegkundigen (pp. 81-100). Utrecht: Lemma.

Vulto, M. E. (2002). Welzijn en waardigheid voor langdurige zorggebruikers (Wellness and dignity for long-term users of health care). Leiden, the Netherlands: Health Management Forum (STG). 
PART II

TOWARDS A LEARNING PROGRAMME AIMED AT CLIENT-CENTRED CARE 



\section{HET ONTWERP VAN EEN LEERTRAJECT IN SAMENSPRAAK:}

Naar een leertraject vraaggerichte zorg op basis van het 'Acht-velden model' van Kessels

Schoot, T., Engels, J., Hollands, L., \& de Witte, L. (2004).

Het ontwerp van een leertraject in samenspraak (The design of a learning programme in dialogue). Onderwijs en Gezondheidszorg(6), 3-10 
Iedereen praat erover, maar niemand weet precies hoe het moet: 'vraaggerichte zorg'. In dit artikel wordt het ontwerp van een leertraject vraaggerichte zorg voor verplegenden en verzorgenden in de praktijk beschreven. Het ontwerp vond plaats op basis van het 'acht velden model' van Kessels (1996). Dit is een samenhangend model voor ontwerp en evaluatie van leertrajecten dat beoogt in nauwe samenwerking met centrale belanghebbenden invulling te geven aan leren. In dit geval vond het ontwerp plaats in samenspraak met cliënten, vertegenwoordigers van cliëntenraden, zorgverleners en management van vier zorgorganisaties. Tevens werden vertegenwoordigers van relevante koepelorganisaties betrokken bij de validering van het ontwerp. Aan het ontwerp van het leertraject was een wetenschappelijk onderzoek gekoppeld. 


\section{INLEIDING}

Om beroepsbeoefenaren beter toe te rusten voor vraaggerichte zorg, werd in 2002 het project 'Scholing in de richting van de vraag: verzorging en verpleging vanuit cliëntenperspectief gestart. Dit project richt zich op het ontwikkelen, implementeren en evalueren van een scholing voor verpleegkundigen en verzorgenden werkzaam in ziekenhuizen en thuiszorg, waarbij het verlenen van vraaggerichte zorg centraal staat (projectplan versie 130103). "Vraaggerichte zorg' bleek een complex concept. Verschillende belanghebbenden (cliënten, zorgverleners, management, verzekeraars, overheid), organisatieniveaus (micro, meso, macro) en wetenschappelijke disciplines geven een verschillende invulling aan wat vraaggerichtheid inhoudt, en wat je hierbij dient te evalueren (van der Kraan 2001; Rijckmans, Garretsen et al. 2002). Al snel na de start van het project werd daarom gezocht naar een kader om systematisch en gezamenlijk vorm te geven aan het te ontwerpen leertraject. Dit kader werd gevonden in het 'acht velden model' van Kessels (1996). Om ontwerp en evaluatie beter te kunnen onderbouwen werd het project ondersteund door onderzoek.

In deze bijdrage wordt het ontwerp van het leertraject 'Zorg in dialoog' beschreven. Na een toelichting op het 'acht velden model' volgt een algemene beschrijving van het ontwerpproces, gebaseerd op dit model en vervolgens een beschrijving van werkwijze en resultaten per veld. In de discussie blikken we op kritische wijze terug en doen we enkele aanbevelingen.

\section{MODEL VOOR ONTWERP EN EVALUATIE}

Kessels (1996) biedt een model om leertrajecten in organisaties vorm te geven. Uitgangspunt hierbij is dat het bij leren in organisaties gaat om het realiseren van leertrajecten die adequate oplossingen bieden voor een bepaalde problematische uitgangssituatie. Het acht velden model biedt een handvat voor het beschrijven van de beoogde situatie (wat wil je bereiken) en van de te evalueren situatie (wanneer ben je tevreden?). Er worden vier velden onderscheiden voor de beschrijving van de beoogde situatie (linker velden). De te evalueren situatie (rechter velden) bevat ook vier velden. Deze zijn de spiegel van de eerder genoemde velden.

Figuur 1 beschrijft de wijze waarop wij het acht velden model toegepast hebben. Vanuit een beschrijving van knelpunten in de huidige situatie worden hoofddoelen beschreven op cliëntniveau. Aansluitend hierop volgt de omschrijving van competent gedrag, hetgeen dient te veranderen in de werksituatie. Het hieronder liggende veld beschrijft het geheel aan hiervoor benodigde kennis, vaardigheden en attitudes. De te ontwerpen leersituaties worden beschreven in het 


\section{Beoogde situatie Te evalueren situatie}

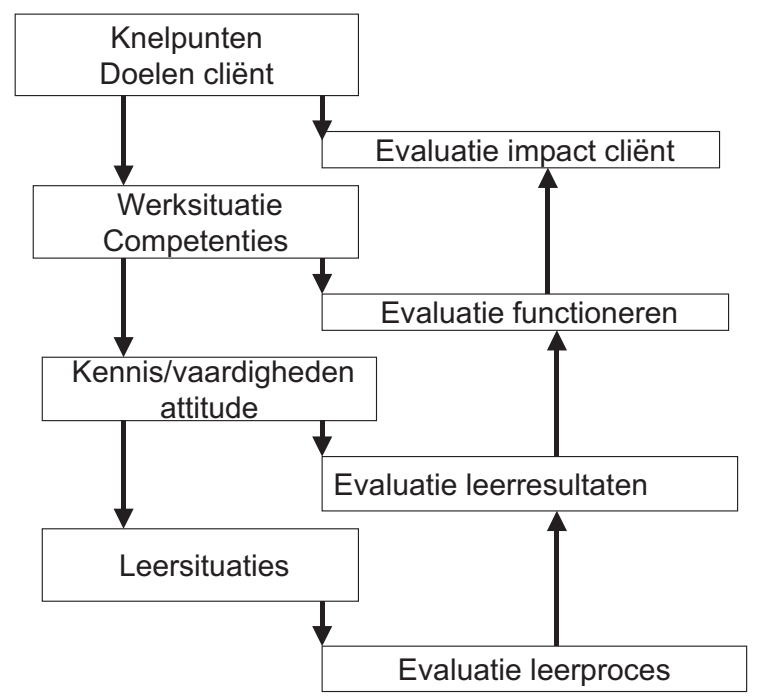

Figuur 1: Toepassing van het acht velden model van Kessels 1996.

onderste linker veld. In het veld rechtsonder wordt nagegaan of de ontworpen leersituaties tot het gewenste leerproces bij professionals hebben geleid. Volgens het hierboven liggende veld dient vervolgens te worden nagegaan of het leerproces resulteert in de gewenste resultaten bij de professionals op het niveau van kennis/vaardigheden en attitude. Of er sprake is van toepassing van het geleerde en of dit leidt tot competent functioneren in de werksituatie wordt aansluitend hierop nagegaan. Het veld rechts boven evalueert of de activiteiten impact hebben gehad bij de cliënt.

\section{Externe consistentie}

Het acht velden model beoogt de basis te zijn van een extern consistent curriculum. Externe consistentie betreft de betrokkenheid bij het ontwerp van leertrajecten van relevante belanghebbenden, en duidt op de overeenkomst die er bestaat tussen de opvattingen van de centrale belanghebbenden over de aard van het probleem dat opgelost dient te worden, over de doelen die nagestreefd worden en over de wijze waarop dat gaat gebeuren.

Aan de richtlijnen voor externe consistentie ligt een relationele benadering ten grondslag. Belanghebbenden worden betrokken bij het ontwerp. Hierdoor wordt de praktijk binnengehaald en wordt draagvlak verkregen voor het leertraject. 


\title{
Interne consistentie
}

Interne consistentie betreft de samenhang tussen de afzonderlijke velden. Aan de richtlijnen voor interne consistentie van Kessels ligt een systematische benadering ten grondslag. Deze draagt bij aan een goed gestructureerd, logisch geordend programma. De samenhang betreft de volgorde van de velden: ieder veld vloeit voort uit het eraan voorafgaande veld. De samenhang is ook aanwezig in de spiegeling van de velden aan elkaar: iedere beoogde situatie wordt ook beschreven als te evalueren situatie. Ieder veld geeft richting aan inhoudelijke vragen die beantwoord dienen te worden.

\section{HET ONTWERP: ALGEMENE WERKWIJZE}

De betrokken partijen bij het ontwerp waren: de projectgroep, een onderzoeksgroep, vier zorgorganisaties, een stuurgroep en een klankbordgroep.

\begin{abstract}
Betrokken partijen bij het ontwerp
De projectgroep bestond uit een combinatie van inhoudsdeskundigen en didactisch deskundigen uit kenniscentra, $\mathrm{HBO}$ - en $\mathrm{MBO}$. Twee van de leden van de projectgroep maakten deel uit van de onderzoeksgroep. De betrokken zorgorganisaties waren drie thuiszorgorganisaties en een ziekenhuis alle in het zuiden van Nederland.

De stuurgroep bestond uit vertegenwoordigers van cliëntenraad, management, staffunctionarissen van de betrokken zorginstellingen en vertegenwoordigers van provinciale koepelorganisaties voor patiënten. De klankbordgroep bestond uit vertegenwoordigers van landelijke koepelorganisaties uit de thuiszorg, ziekenhuiszorg en van de verpleegkundige en verzorgende beroepsgroepen (projectplan versie 130103).
\end{abstract}

De volgende werkwijze werd gehanteerd:

\section{Onderzoek beoogde situatie}

Om de beoogde situatie te verhelderen werden d.m.v. zorgvuldig onderzoek data verzameld bij diverse belanghebbenden; m.n. uit de betrokken zorgorganisaties. Centrale vragen hierbij betroffen het cliëntenperspectief op vraaggerichte zorg; de door professionals ervaren knelpunten en dilemma's. Het onderzoek dat getoetst werd conform de gedragscode Gezondheidszorgonderzoek, werd door een Medisch-ethische Toetsingscommissie positief en relevant bevonden. In het onderzoek werd gestart met enkele oriënterende interviews waaraan de volgendegroepen deelnamen: zorgvragers, mantelzorgers, zorgverleners, managers, opleiders en verzekeraars. Vervolgens werden twee focusinterviews gehouden met ervaringsdeskundige cliënten en mantelzorgers die werkzaam 
waren als patientvoorlichters bij de Chronisch zieken en Gehandicapten Raad Nederland (CG-Raad). Er vonden participerende observaties van het primaire zorgproces plaats en aansluitend werden enkele diepte-interviews met betreffende cliënten en met zorgverleners gehouden.

\section{Bespreking in de projectgroep}

De eerste resultaten werden op basis van rapportages, verslagen en presentaties in de projectgroep besproken. In meerdere consensusronden resulteerden deze besprekingen uiteindelijk in concepten gericht op de beoogde situaties. Deze concepten werden ter validering voorgelegd aan de stuurgroep en de klankbordgroep en na correctie door de projectgroep vastgesteld.

\section{Dialoog met betrokken partijen}

Resultaten van de projectgroep werden ter bespreking voorgelegd aan de stuurgroep en aan de klankbordgroep. Door middel van schriftelijke informatie, presentaties en gesprekken werd gewerkt aan begrip en medewerking bij de opleidingsfunctionarissen en bij zoveel mogelijk betrokken managers in de betreffende pilot- organisaties. Met name de opleidings c.q. staffunctionarissen fungeerden als contactpersoon bij de noodzakelijke dataverzameling en -planning. In alle organisaties speelde het middenmanagement een rol als tussenpersoon bij de inventarisatie van casuïstieken en knelpunten uit de werksituatie. Hiertoe werden (midden)managers en opleidingsfunctionarissen geïnterviewd. Diverse keuzes m.b.t. het leertraject, bijvoorbeeld m.b.t. kenmerken van de doelgroep, selectie van deelnemers en planning, vonden plaats in dialoog met de contactpersonen.

\section{Ontwikkelen en testen van evaluatie-instrumenten}

$\mathrm{Na}$ vaststelling van de inhouden van de velden die de beoogde situatie betreffen, werden deze aansluitend nader geoperationaliseerd tot evaluatie-instrumenten. De proces-evaluatie-instrumenten vloeiden direct voort uit de onderwijs-visie en gekozen onderwijsinhouden. De vastgestelde doelen op de niveaus kennis, vaardigheden en attitude vormden de basis voor een zelfevaluatie- instrument. De geformuleerde competenties in de werksituatie werden geoperationaliseerd tot een competentieschaal.

Cliëntdoelen werden geoperationaliseerd tot een evaluatie-instrument t.b.v. cliënten. De concepten werden toegelicht en besproken in de stuurgroep. Van de klankbordgroep werd één lid (Sting) gericht benaderd voor reacties. Conceptinstrumenten werden besproken met de projectgroep en met enkele wetenschappelijk begeleiders. De competentieschaal t.b.v. het functioneren in de werksituatie werd na een tryout bij enkele professionals bijgesteld. Het cliënt 
evaluatie-instrument werd in een pilotmeting bij enkele cliënten getest en bijgesteld op grond van de bevindingen.

\section{HET ONTWERP PER VELD}

\section{Veld: Knelpunten en doelen cliënt}

De startvraag voor het gehele project was: 'welke knelpunten ervaren cliënten in de huidige situatie en wat is het perspectief van cliënten op de gewenste/ beoogde situatie?' Deze vraag betrof de hoofddoelen van het leertraject. Bij de beantwoording van deze vraag speelden m.n. de focusgroep-interviews met ervaringsdeskundige patiënten een rol (Schoot, Proot et al. 2004) evenals de participerende observaties.

Mensen die zorg ontvangen, willen een actieve rol spelen in het zorgproces. $\mathrm{Zij}$ verwachten van een zorgverlener dat deze zich primair richt op de ondersteuning van het totale, individuele bestaan. Hiertoe dient de zorgverlener de autonomie (en eigen regie) en ervaringsdeskundigheid van de cliënt op basis van gelijkwaardige dialoog te erkennen, te respecteren en te bevorderen. Voorts zouden zorgverleners oplettende en kritische ‘bondgenoten' moeten zijn in het bereiken van de doelen van de cliënt.

De werkdefinitie van vraaggerichte zorg hebben we als volgt beschreven:

\section{Werkdefinitie}

Vraaggerichte zorg is zorg die uitgaat van de wensen en ervaren behoeften van de zorgvrager, die in dialoog tot stand komt en waarbij de zorgvrager uiteindelijk beslist.

Doelen bij de cliënt werden voor dit project gedefinieerd als:

\section{Doelen cliënt}

De zorgvrager geeft aan door de zorgverlener serieus genomen te worden en gerespecteerd te worden.

De zorgvrager geeft aan autonomie te ervaren ten aanzien van de wijze waarop de zorg wordt vorm gegeven.

\section{Veld: De werksituatie}

Dit veld betreft het totaal van hetgeen dient te veranderen in de werksituatie. De werksituatie werd voor dit project afgebakend tot het effectief functioneren van de zorgverlener in het primaire proces voor zover het binnen zijn/haar compe- 
tentiegebied ligt. In de praktijk doen zich vaak situaties voor waarbij sprake is van grenzen, spanningsvelden en dilemma's bij het gestalte geven aan de beoogde zorg. Het kunnen omgaan met dergelijke situaties behoort eveneens tot de werksituatie van zorgverleners. We noemden het effectief functioneren in de werksituatie 'competenties'. Centrale vragen voor dit veld betroffen: wat is het perspectief van cliënten en van zorgverleners op competent functioneren in de werksituatie; welke spanningsvelden ervaren professionals in de werksituatie en op welke wijze kunnen zij effectief hiermee omgaan? De beschreven werkwijze resulteerde in de vaststelling van drie centrale competenties:

\section{Competent functioneren in de werksituatie}

1. De verpleegkundige / verzorgende doorloopt in dialoog met de zorgvrager het zorgproces vanuit het perspectief van de zorgvrager op basis van zijn/haar professionele deskundigheid. De verpleegkundige is in staat om te gaan met te verwachten knelpunten en spanningsvelden daarbij.

2. De verpleegkundige / verzorgende ondersteunt de zorgvrager bij het formuleren van zijn/haar vragen en wensen ten aanzien van het gehele zorgproces en stimuleert daarbij de regievoering door de zorgvrager. De verpleegkundige is in staat om te gaan met te verwachten knelpunten en spanningsvelden daarbij.

3. De verpleegkundige / verzorgende zoekt actief naar alternatieve mogelijkheden op het moment dat persoonlijke, professionele en organisatorische grenzen zich voordoen.

\section{Veld: Benodigde kennis, vaardigheden en attitude}

Centrale vraag bij dit veld is: welke concrete kennis, vaardigheden en attitude zijn nodig om competent te kunnen functioneren in de werksituatie? De vastgestelde competenties werden geanalyseerd naar doelstellingen m.b.t. benodigde kennis, vaardigheden en attitude. Vervolgens werden deze doelstellingen gekoppeld aan de diverse dagdelen.

\section{Fragment doelstellingen}

De zorgverlener:

-Kan benoemen wat patiënten belangrijk vinden in de zorgverlening (patientenperspectief)

-Kan benoemen welke gevolgen het hebben van een chronische aandoening heeft op psychosociaal, economisch en maatschappelijk vlak

-Heeft kennis van de begrippen draaglast en draagkracht en kan deze toepassen

-Kan beargumenteren hoe de zorgverlening de zorgvrager kan helpen zijn eigen leven te leiden 


\section{Veld: Ontwerp van leersituaties}

Teneinde de zorgverleners in de gelegenheid te stellen om de benodigde kennis, vaardigheden en attitude te ontwikkelen c.q. (blijvend) effectief leren functioneren in de werksituatie, werden leersituaties bedacht. Centrale vragen waren:

- Welke leersituaties passen bij het verwerven van deze kennis, vaardigheden en attituden/de ontwikkeling van competenties?

- Op welke manier kunnen we de dagelijkse werkpraktijk benutten?

- Hoe kunnen we bijdragen aan transfer en blijvend effect?

- Hoe kunnen we zorgen dat docenten goed reageren op de vragen/problemen waarmee ze geconfronteerd worden?

Om aan te sluiten bij de belevingswereld van de deelnemers wordt zoveel mogelijk gebruik gemaakt van de casuistiek uit de eigen werksituatie. In principe speelt juist het leren in en 'aan' de eigen werksituatie een overheersende rol bij het teweegbrengen van de gewenste effecten (Kessels 1996). Zorgverleners worden aangemoedigd om zelf of met elkaar praktijkproblemen op te lossen en daarbij zelf te beoordelen over welke competenties ze wel en niet beschikken. De deelnemer krijgt dus een actieve rol. Het is met name deze methode die professionals aanspreekt: zij willen vooral 'zichzelf iets leren' waarvan zij de zin inzien, en niet iets aangeleerd krijgen (Jutte \& Kruyt, 1999).

Transfer en blijvend effect worden beoogd door het aanbieden van methodieken om gezamenlijk, systematisch en structureel het functioneren in de werksituatie te bespreken. Op deze wijze wordt dit onderdeel gemaakt van de praktijkcultuur (Bolhuis, 2001). Voorbeelden hiervan in het ontworpen leertraject zijn: structurele en systematische refl ectie en een methodiek voor het gezamenlijk omgaan met ethische dilemma's. Een bijdrage aan een 'olievlekwerking' in de praktijk werd ook verwacht van selectiecriteria voor de deelnemers (zie beschrijving). Om brede bewustwording in de organisatie te creëren werd de basismodule opengesteld voor (midden)management en staffunctionarissen. De verwachting was dat dit zal bijdragen aan ondersteuning en facilitering van de zorgverlener.

In het leertraject staan communicatieve vaardigheden, ethisch redeneren en reflectieve vaardigheden centraal. Ondanks dat veel van deze vaardigheden m.n. worden toegeschreven aan de hoogste niveaus van verplegen (Pool, Pool-Tromp et al., 2001), is het leertraject ontwikkeld voor verpleegkundigen en verzorgenden van kwalificatieniveau 3, 4 en 5 . Onderliggende gedachte is dat ze samen staan voor één en dezelfde groep zorgvragers, dat in teamverband geleerd wordt en dat ieder lid van het team zich hier verder in kan ontwikkelen. De gekozen leersituaties maken duidelijk welke eisen gesteld worden aan de rol en competenties van de docent (Auer, 1994; de Koning, 2002):

- Het begeleiden van groepsprocessen; 
- het initiëren/stimuleren van processen in de organisatie die bijdragen aan transfer en implementatie;

- het begeleiden van individuele leerprocessen als coach;

- het trainen van vaardigheden op het gebied van communicatie, ethisch redeneren en reflecteren;

- optreden als rolmodel bij de toepassing van vraaggerichte zorg.

\section{Beschrijving van het leertraject 'Vraaggerichte Zorg in dialoog'}

Het programma bestaat uit een basis- en vervolgmodule variant Thuiszorg en variant Klinische zorg. In de basismodule ligt de nadruk op bewustwording van knelpunten in de huidige situatie en een oriëntering op de wensen en behoeften van zorgvragers. Deze module is bedoeld voor zorgverleners die functioneren op niveau $3 \mathrm{t} / \mathrm{m} 5$ en hun managers en stafverpleegkundigen (totaal 25-30) en betreft twee dagdelen. Er zijn diverse werkvormen zoals een stellingenspel, een presentatie door een ervaringsdeskundige, rollenspelen gekoppeld aan een zorgcircuit en een cheklist vraaggerichtheid. De vervolgmodule betreft 7 dagdelen. Het programma is in eerste instantie gericht op de doelstellingen m.b.t. kennis, attitude, samenwerkings- en communicatieve vaardigheden, en ethisch redeneren. Richtinggevend hierbij zijn de vastgestelde competenties. In drie dagdelen komt een aantal verschillende typen taken aan bod. In twee dagdelen staan trainingen vaardigheden centraal.

Taken en trainingen zijn gebaseerd op praktijksituaties. De laatste twee bijeenkomsten zijn follow-up- bijeenkomsten. M.n. vanaf dit moment staan de geïntegreerde competenties centraal: toepassing in hun eigen praktijk en de ervaringen die de deelnemers hierbij opdoen. Reflectie op eigen gedrag en op het gedrag van collega's en het geven van feedback is hierbij een belangrijke werkvorm. Alle dagdelen zijn omringd met opdrachten gericht op de toepassing in de dagelijkse praktijk. Het programma beoogt ook ruimte te bieden voor individuele leerdoelen. Bij beide modulen worden ervaringsdeskundige voorlichters van de Chronisch zieken en Gehandicapten Raad Nederland ingezet. Betreffende personen hebben een voorbereidende training gevolgd. Bij het leertraject hoort een uitgebreide docentenhandleiding en een handleiding voor de ervaringsdeskundige voorlichters. Hierin is zowel aandacht voor de werkwijze als voor de inhoud.

\section{Veld: Evaluatie van het leerproces}

Hoe kunnen we het verloop van de leerprocessen evalueren?

Om inzicht te krijgen of het leerproces van de deelnemers verloopt zoals beoogd, is gestreefd naar instrumenten gericht op het verzamelen van een mix van zowel kwalitatieve als kwantitatieve data. De ontworpen instrumenten sturen zowel naar dataverzameling bij de docent en de ervaringsdeskundige als bij de deelnemers. Tevens wordt gestuurd naar dataverzameling op meerdere momenten. Het instrument wordt gekenmerkt door:

- Richtlijnen voor een mondelinge evaluatie aan het eind van iedere bijeenkomst; 
- Bespreking van ervaringen van tutoren en ervaringsdeskundigen in een tutorenoverleg;

- Schriftelijke programma-evaluatie met behulp van een voorgestructureerde vragenlijst aan het einde van de laatste bijeenkomst. De vragenlijst betreft alle substantiële onderdelen van het leertraject. De antwoorden kunnen gegeven worden op een vijfpuntsschaal: $1=$ helemaal niet mee eens; $5=$ helemaal mee eens;

- Open vragen als onderdeel van de programma-evaluatie

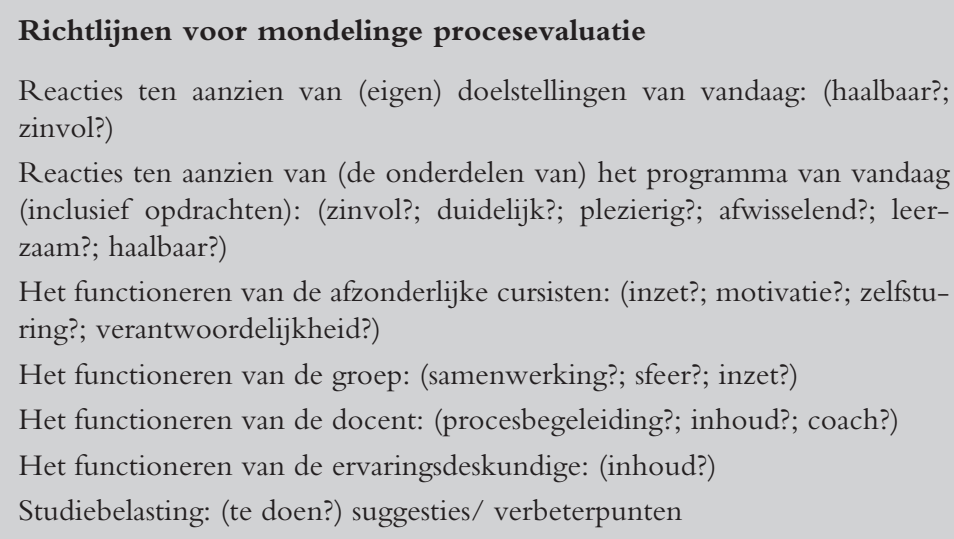

\section{Veld: evaluatie van leerresultaten}

Hoe kunnen professionals inzicht krijgen in de kennis, vaardigheden en attitude die zij hebben verworven? Toetsing en evaluatie is een essentieel onderdeel van het leerproces, en vindt bij voorkeur zowel aan het begin, tijdens als aan het einde van een leertraject plaats. Hierdoor verwerven deelnemers kennis over hun eigen voortgang. Het zelfevaluatieformulier is een instrument om zicht te krijgen op aanwezige kennis; vaardigheden en attitude. Dit instrument dient als zelfbeoordeling te worden gebruikt bij de reflectie op eigen kennis, vaardigheden en attitude. Betrokkenen kunnen in overwegend open antwoorden reflecteren op hoever zij hierin zijn. Daarnaast bevat de vragenlijst ruimte voor conclusies t.a.v. leerpunten en t.a.v. vervolgactiviteiten. 


\section{Fragment uit het 'Zelf-evaluatieformulier' \\ In welke mate vind je dat je zelf voldoet aan de volgende doelstellingen? \\ Omcirkel één cijfer, waarbij 1 = onvoldoende, $2=$ twijfelachtig, \\ $3=$ voldoende, $4=$ ruimschoots voldoende en $5=$ goed.}

\section{Kennis}

Kennis en inzicht in de begrippen autonomie, eigen regelgeving, zelfbeschikking en empowerment

Inzicht in mogelijke levensvragen en (inlevingsvermogen in) participatieproblemen van zorgvragers

Kennis en inzicht in de gevolgen van het hebben van een aandoening c.q. zorgvraag op psychosociaal, economisch en maatschappelijk vlak

Mijn sterke punten zijn:

Verbeterpunten voor mij zijn:

\section{Veld: Evaluatie van het functioneren in de werksituatie}

Op welke wijze kunnen professionals hun ontwikkeling t.a.v. competent functioneren in de werksituatie evalueren? Teneinde inzicht te verkrijgen in (de ontwikkeling van) eigen competenties in de werksituatie werd de Competentieschaal 'Zorg in dialoog' ontwikkeld. Leren doe je individueel, maar in toenemende mate ook samen met collega's, met managers, met de hele organisatie. De schaal gaat daarom uit van self- en peer-assessment: zorgverleners worden gestimuleerd om zichzelf kritisch te beoordelen en om hierbij feedback te vragen aan relevante anderen (Dochy, Heylen et al., 2002).

Het instrument stuurt naar het vergaren van 360 graden feedback: het gericht vragen om feedback over het eigen gedrag aan diverse betrokkenen met een verschillend perspectief (patiënten, mantelzorgers, collega's, leidinggevenden). De competentieschaal beschrijft 10-15 indicatoren van gewenst gedrag in de werksituatie per competentie. Betrokkenen kunnen aangeven op een schaal van $1-4$ in hoeverre het beschreven gedrag op hen van toepassing is. Daarnaast bevat de vragenlijst ruimte om te verantwoorden op welke wijze feedback is gevraagd; ruimte voor conclusies t.a.v. de voortgang en t.a.v. leerpunten. Er is vooraf geen minimumnorm vastgesteld. Nadruk ligt op het verwerven van zelfi nzicht en refl ectie t.a.v. individuele ontwikkelingen. Dat betekent zeker niet dat de zelfevaluatie vrijblijvend is. De interne samenhang van de velden maakt het belang ook duidelijk van een gedegen evaluatie van iedere stap. 


\section{Fragment uit de 'Zorg in dialoog' Competentieschaal}

Geef bij ieder van de onderstaande uitspraken aan in hoeverre het beschreven gedrag op jezelf van toepassing is in de werksituatie met cliënten.

Er zijn vier keuzemogelijkheden: 1 = eigenlijk niet; 2 = in beperkte mate; 3 = regelmatig; 4 = heel vaak.

\section{Competentie 3:}

-ik geef duidelijkheid aan de cliënt over organisatorische, professionele en persoonlijke mogelijkheden en beperkingen;

-ik zoek actief naar alternatieve mogelijkheden om aan de zorgvraag van de cliënt tegemoet te komen bij persoonlijke, professionele of organisatorische grenzen;

-ik ondersteun collega's bij het zoeken naar alternatieve mogelijkheden om aan de vraag van de cliënt tegemoet te komen bij persoonlijke, professionele of organisatorische grenzen;

-ik draag zorg voor de randvoorwaarden in de organisatie die de ondersteuning van de eigen regie van de cliënt ondersteunen;

-ik sta open voor kritiek van de cliënt;

-ik sta open voor kritiek van collega's;

\section{Veld: Evaluatie van de ervaren vraaggerichtheid door de cliënt}

Hoe kunnen we de door de cliënt ervaren vraaggerichtheid evalueren? Cliëntdoelstellingen (het eerste veld) werden geoperationaliseerd tot indicatoren van door de cliënt ervaren vraaggerichtheid. Het instrument bevat 15 uitspraken m.b.t. aspecten van vraaggerichtheid. Cliënten kunnen aangeven op een schaal van 1-5 hoe zij dit ervaren (helemaal niet mee eens-helemaal mee eens). Daarnaast bevat de vragenlijst twee open vragen naar wat men goed vindt aan de zorg die men ontvangt en naar wat men vindt dat beter zou kunnen. Tot slot is er nog een vraag naar een waardering in een rapportcijfer, en naar eventuele gesignaleerde veranderingen in de zorg. Er is vooraf geen minimumnorm vastgesteld. Het instrument kan gebruikt worden door individuele beroepsbeoefenaren om feedback over de effecten van het eigen functioneren te verzamelen. Het instrument kan ook gebruikt worden voor gegevensverzameling op afdelings c.q. clusterniveau.

\section{Fragment uit het evaluatieinstrument t.b.v. cliënten}

De antwoordmogelijkheden zijn: helemaal niet mee eens; niet mee eens, weet niet/ geen mening, mee eens en helemaal mee eens

Ik merk dat zorgverleners rekening houden met mijn persoonlijke wensen. Ik merk dat zorgverleners echt naar mij luisteren.

Ik merk dat zorgverleners rekening houden met wat ik hen verteld heb.

Ik krijg voldoende gelegenheid om te zeggen aan welke zorg ik behoefte heb. 


\section{REFLECTIE}

\section{Mogelijkheden}

Het acht velden model betekende voor ons een prima houvast voor een gezamenlijk en systematisch ontwerp van een leertraject. Het prikkelde tot afstemming op de zorgverlener in de werksituatie. Daarnaast stuurde het model naar een zo groot mogelijk draagvlak van het leertraject door samenspraak met relevante belanghebbenden. Het draagvlak betrof hierbij zowel de betreffende pilotorganisaties als vertegenwoordigers van diverse groepen belanghebbenden in den lande.

\section{Grenzen}

Door het leertraject wordt een belangrijke impuls gegeven aan de bevordering van vraaggerichte zorg. Vraaggerichte zorg omvat echter veel meer dan alleen het competent functioneren van zorgverleners in het primaire proces. Het acht velden model van Kessels beoogt te anticiperen op alle elementen in de werksituatie die bijdragen aan het probleem in de uitgangssituatie. Bijvoorbeeld instellingsbeleid en managementcompetenties. Dit totaalplaatje valt buiten de doelstelling van het project. Het ontwikkelde leertraject betreft voornamelijk het effectief functioneren van de zorgverlener in de praktijk binnen de gegeven mogelijkheden en grenzen. Wij beschrijven dit als competenties van de zorgverlener in de werksituatie en onderscheiden dit van kennis, vaardigheden en attitude. Hier wijkt de toepassing van het model af van het oorspronkelijke model. Het gevaar van het niet volledig meenemen van de werksituatie is, dat een oplossing wordt bedacht die niet volledig passend is voor het oorspronkelijke probleem.

\section{AANBEVELINGEN}

Uit het beschreven traject is gebleken dat diverse maatregelen werden genomen om belangrijke derden uit de werksituatie te betrekken bij het ontwerp. Ook werden diverse maatregelen genomen om transfer van het geleerde in de werksituatie en het uitdragen naar collega's zoveel mogelijk te bevorderen. Dit verdient echter nog verdere aandacht. Een actiefleerklimaat en een actief opleidingsbeleid en ondersteuning door het management zijn hierbij van essentieel belang. Dit blijft een punt van aandacht bij de implementatie op grotere schaal (Kessels 1996). Met het volgen van de module 'zorg in dialoog' zijn zorgverleners dus nog niet 'klaar' voor vraaggerichte zorg. Dit vraagt een langer en breder gedragen traject. 


\section{De ondersteuning met onderzoek}

De input van centrale belanghebbenden werd voor een groot gedeelte gerealiseerd door zorgvuldig onderzoek bij belanghebbenden. Het principe van triangulatie (diverse bronnen en dataverzamelingstechnieken) was hierbij van belang. Hierdoor werd de externe validiteit van het leertraject, en daarmee het draagvlak voor de implementatie vergroot. Een knelpunt van de combinatie van het ontwerp met zorgvuldig onderzoek was dat door de tijdsdruk van het te ontwikkelen leertraject er op diverse momenten gebruik gemaakt moest worden van tussentijdse onderzoeksresultaten. Deze tijdsdruk werd nog versterkt door de noodzakelijke toetsing van het onderzoek door de medisch-ethische commissie. Zowel de langdurige en bewerkelijke procedure van dit traject, als de overeengekomen gedragscode die gold voor het onderzoek (bijvoorbeeld de geïnformeerde toestemmingsprocedure) werkten belemmerend en vertragend voor het onderzoek. Zorgvuldig onderzoek bleek soms spanningen op te leveren met planning en fl exibiliteit in de organisatie. Bijvoorbeeld wijzigingen en onvoorziene zaken in de patiëntenplanning doorkruisten soms de geïnformeerde toestemming van cliënten; theoretische steekproeftrekking in het kader van kwalitatief onderzoek (hierbij worden gaandeweg het onderzoeksproces keuzes gemaakt m.b.t. kenmerken van nieuwe te selecteren onderzoekssituaties) stond op gespannen voet met de planning van onderzoeksactiviteiten in de organisatie. Het gezamenlijk zoeken naar een evenwicht verliep succesvol dankzij inzet, dialoog en creativiteit bij de betrokken partijen.

\section{Toepassingsmogelijkheden}

Het leertraject vraaggerichte zorg biedt aanknopingspunten voor verplegenden en verzorgenden die zorg bieden aan cliënten van alle zorgcategorieën (chronisch zieken, klinische zorg, kind- en jeugdzorg etc). Echter, om aan te sluiten bij de belevingswereld van de betreffende deelnemer is het van belang zoveel mogelijk de casuistiek aan te passen aan de eigen werksituatie. Momenteel is reeds een variant thuiszorg en klinische zorg ontwikkeld. Diverse onderdelen van het ontwikkelde leertraject bieden mogelijkheden voor integratie in het reguliere curriculum van verpleegkundige en verzorgende opleidingen. Het programma biedt tevens mogelijkheden voor toepassing naar andere zorg- en hulpverleners dan verplegenden en verzorgenden.

\section{DANKWOORD}

Het ontwerp kwam tot stand dankzij de bijdrage van diverse personen: Marja Legius (Fontys Hogescholen) en Math Hirsch (Arcus College) beiden leden van de projectgroep; leden van de stuur- en klankbordgroep; betrokken ervarings- 
deskundigen; medewerkers en cliënten van de pilot-organisaties; medewerkers van bureau onderzoeksverwerking Audit \& Control van de Hogeschool Zuyd; leden en inhoudsdeskundige van de subgroep 'vraaggerichte zorg' van de kenniskring 'Autonomie en Participatie' Hogeschool Zuyd.

\section{LITERATUUR}

Auer, C., Ed. (1994). Opleiders in Organisaties, Capita Selecta. Professionals en opleiden: een begripsafbakening. Deventer, Kluwer Bedrijfswetenschappen.

Bolhuis, S. (2001). Leren en veranderen bij volwassenen. Bussum, Coutinho.

Dochy, F., L. Heylen, et al. (2002). Assessment in het onderwijs: nieuwe toetsvormen en examinering in studentgericht onderwijs en competentiegericht onderwijs. Utrecht, Lemma.

Jutte, C. \& L. Kruyt (1999). 'Professionals kun je niet trainen.' Gids voor personeelsmanagement jaargang 78, nr 9, p21-25

Kessels, J. W. M. (1996). Succesvol ontwerpen: curriculumconsistentie in opleidingen. Deventer,, Kluwer Bedrijfswetenschappen Enschede.

Koning, de, J. (2002). 'Een goede leeromgeving, Vraaggestuurd werken bij Stichting de Bollenstreek.' Markant 14 p. 14-17.

Kraan, van der, W. G. M. (2001). Vraaggericht en vraaggestuurd. Een literatuurstudie naar vraaggerichtheid en vraagsturing in de gezondheidszorg. Den Haag, ZonMw.

Pool, A., C. Pool-Tromp, et al. (2001). Met het oog op de toekomst. Beroepscompetenties van HBO-Verpleegkundigen. Utrecht, NIZW.

Rijckmans, M. J. M., H. F. I. Garretsen, et al. (2002). 'Vraaggerichtheid en vraagsturing. Een poging tot conceptuele verheldering.' Tijdschrift voor Sociale Gezondheidszorg 80, 388-392.

Schoot, C. M., I. M. Proot, et al. (2004). 'Recognition of cliënt values as a basis for tailored care: the view of Dutch expert patients and family caregivers.Scandinavian Journal of caring Sciences, 19,169-176.

Project 'Scholing in de richting van de vraag: verzorging en verpleging vanuit patiëntenperspectief versie 130103 
Part III

EVALUATION OF THE LEARNING PROGRAMME AIMED AT CLIENTCENTRED CARE 



\section{ZELFBEOORDELING VAN} COMPETENTIES VOOR VRAAGGERICHTE ZORG IN DE THUISZORG

De ontwikkeling van de Zorg in dialoog Competentie Schaal

Schoot, T., Proot, I. \& de Witte, L. (2005).

Zelfbeoordeling van competenties voor vraaggerichte zorg in de thuiszorg: De ontwikkeling van de Zorg in dialoog Competentie Schaal. October 2006, Verpleegkunde. In press. 


\section{SAMENVATTING}

Doel: Dit artikel beschrijft de ontwikkeling en het testen van de 'Zorg in dialoog Competentie Schaal' voor thuiszorgverpleegkundigen en -verzorgenden van mensen met een chronische ziekte. Met deze zelfbeoordelingsschaal kunnen de competenties voor vraaggerichte zorg aan chronisch zieke cliënten in de thuiszorg gemeten worden.

Methode: Het instrument werd ontwikkeld op basis van kwalitatief onderzoek naar het perspectief van cliënten en verpleegkundigen op vraaggerichte thuiszorg. Vertegenwoordigers van cliënten, verpleegkundigen en hun managers werden op systematische wijze betrokken bij het definiëren van drie competenties voor vraaggerichte zorg: 1 zorgproces in dialoog, 2 ondersteuning cliëntparticipatie, 3 omgaan met spanningsvelden. Deze werden geoperationaliseerd tot schalen van respectievelijk 18, 10 en 8 gedragsitems. Het instrument werd getest bij 74 verpleegkundigen en verzorgenden van vier thuiszorgorganisaties in het zuiden van Nederland. De respondenten varieerden qua geslacht, opleidingsniveau (niveau 3IG, 4 en 5), leeftijd, ervaring en omvang van de aanstelling. Met behulp van principale componentenanalyse en Cronbach's alpha werd de interne consistentie van de drie schalen onderzocht.

Resultaat: Het merendeel van de items had hoge factorladingen op de eerste factor. Items met een factorlading $<, 40$ op de eerste factor werden uit de schaal verwijderd. Drie items met een factorlading $<, 40$ en $\geq, 30$ werden op inhoudelijke gronden behouden. De interne consistentie van de resterende items bleek redelijk tot goed (Cronbach's alpha competentie $1=, 81$, competentie $2=, 78$, competentie $3=, 74)$. Zoals verwacht, werden geen significante verschillen gevonden tussen de gemiddelde somscores per competentie per organisatie en werden geen correlaties gevonden tussen de individuele somscores en de achtergrondvariabelen. De constructvaliditeit, interne consistentie en bruikbaarheid van de aangepaste schalen bleken voldoende tot goed te zijn.

Conclusie: het instrument biedt mogelijkheden voor evaluatie en zelfreflectie met betrekking tot competenties voor vraaggerichte zorg. Verder onderzoek naar de betrouwbaarheid, validiteit en responsiviteit van het instrument wordt aanbevolen.

Key words: client-centred care; development of compententies, self-assessment nurses, auxiliary nurses, homecare. 


\section{INLEIDING}

Het cliëntenperspectief is in toenemende mate het vertrekpunt van zorg (Goudriaan \& Vaalburg, 1998; Van der Kraan, 2001). 'De cliënt centraal' is een slogan die ieder zichzelf respecterende zorgorganisatie en zorgverzekeraar hoog in het vaandel heeft staan. Nieuwe zorgconcepten, zoals vraaggestuurde zorg en vraaggerichte zorg, zijn een antwoord op deze ontwikkeling (Habets \& Koning, 1999; Verbeek \& Tiemersma, 1998). Het zijn thema's die een hoge actualiteitswaarde bezitten. Van vraaggerichte zorg wordt verwacht dat deze bijdraagt aan de kwaliteit van zorg en de kwaliteit van leven. Cliënten zijn steeds meer een partij geworden in de gezondheidszorg waarmee rekening gehouden dient te worden. De overheid heeft de centrale positie van de cliënt bekrachtigd in wetgeving als de Wet op de Geneeskundige Behandelingsovereenkomst (WGBO), de Kwaliteitswet Zorginstellingen, de Wet Medezeggenschap Cliënten Zorginstellingen (WMCZ) en het klachtrecht. De introductie van vraaggerichte zorg wordt ondersteund door politieke en economische maatregelen, zoals het persoonsgebonden budget en de introductie van marktwerking. Vooral voor cliënten in sectoren waarin langdurige zorg nodig is, zoals bij chronisch zieken die thuiszorg ontvangen, is vraaggerichte zorg van belang. De chronisch zieken zijn bovendien een sterk groeiende groep die in toenemende mate een beroep zal doen op zorg (Ruwaard \& Kramers, 1997; Ruwaard et al., 1999). Vraaggerichte zorg stelt de individuele cliënt en zijn leven centraal in plaats van de ziekte, het eigen zorgaanbod en de grenzen van de eigen discipline of organisatie (VWS, 1999). Deze ontwikkeling is te zien bij chronisch zieken, maar ook bij diverse andere patiëntengroepen, en in diverse andere westerse landen (Cahill, 1998; De Klaver \& Scholten, 2002; Latvala, 2002; WHO, 1996). In toenemende mate wordt erkend dat vraaggerichte zorg essentieel is en bijdraagt aan beoogde zorgresultaten (Lewin et al., 2001).

Vraaggerichte zorg wordt door de Raad voor de Volksgezondheid (RVZ) gedefinieerd als 'een gezamenlijke inspanning van cliënt en verpleegkundigen die erin resulteert dat de cliënt de hulp ontvangt die tegemoetkomt aan zijn wensen en verwachtingen en die tevens voldoet aan de professionele standaarden' (RVZ, 1998). In de praktijk blijkt het gestalte geven aan vraaggerichte zorg niet eenvoudig (Rijckmans et al., 2002; Van der Kraan, 2001).

ZonMw heeft diverse projecten gefinancierd waarin geëxperimenteerd is met het verbeteren van een vraaggerichte houding van professionals in de zorg (ZonMw, 2004). Deze projecten variëren van vaardigheidstrainingen en het inzetten van getrainde cliënten als docent tot bijeenkomsten waar patiënten het woord doen.

Leertrajecten en cursussen, ontwikkeld met het oog op de bevordering van vraaggerichtheid, richten zich op het verwerven of versterken van competenties 
van professionals die een vraaggerichte benadering ondersteunen (KITTZ, 2004; Schoot et al., 2004). Een van de uitdagingen voor betrokkenen is het meten van veranderingen/effecten van het afgelegde leertraject.

Het doel van deze studie is het ontwikkelen en testen van een instrument om competenties die verpleegkundigen bij vraaggerichte zorg toedienen te passen en te meten. Hierdoor kan inzicht worden verkregen in de eigen competenties. Dit is nodig om de vraaggerichtheid van de eigen zorg te kunnen optimaliseren. De onderzoeksvraag was: Hoe kan de zorgverlener zijn competenties voor vraaggerichte zorg meten op valide en betrouwbare wijze. Een competentie werd hierbij gedefinieerd als 'een samenstel van complexe vaardigheden in de context van een beroepssituatie'. Een competentie is afhankelijk van een juiste inschatting en beoordeling van situaties om kennis en vaardigheden op het goede moment en op een goede manier te hanteren' (Leistra et al., 1999) (p.39). Het gaat bij competenties om de manier waarop de zorgverlener zijn werkzaamheden verricht in de praktijk. Er bestaan diverse mogelijkheden om vast te stellen hoe competentieontwikkeling vordert. Tillema stelt dat een kenmerk van alle performance assessmentinstrumenten is dat zij een nauwe relatie hebben met het dagelijks functioneren in de praktijk (Tillema, 1997). Eén hiervan, 'self-assessment', werd gekozen voor deze studie. Self-assessment is het vaststellen van het niveau van beheersing van competenties door de medewerker zelf, meestal door beoordelingsschalen over werkgedrag behorend bij een competentie (Tillema, 1997).

\section{METHODE}

\section{Literatuurstudie}

Teneinde de onderzoeksvraag te beantwoorden is allereerst een literatuurstudie verricht. Er werd gezocht op het trefwoord 'vraaggerichte zorg' in de collecties van een hogeschoolbibliotheek, een universiteitsbibliotheek, het Landelijk Expertisecentrum Verpleging \& Verzorging (LEVV) en op diverse websites. Daarnaast werden diverse individuele experts op dit terrein geraadpleegd. Aansluitend werd naar meetinstrumenten rond vraaggerichte zorg gezocht in Pubmed en de Cochrane Library. Trefwoorden waren: client-centred care, patient-centred care, person-centred care. Equivalenten als centered, oriented en focused werden opgenomen, in de zoekstrategie, alsmede equivalenten zonder verbindingsstreepje. De zoekperiode omvatte de periode januari 1998 tot juli 2003. De zoektocht in Pubmed leverde 466 bronnen op. Deze werden aan de hand van de abstracts gescreend op het gebruik van een meetinstrument voor competenties van verpleegkundigen in de thuiszorg, gerelateerd aan vraaggerichte zorg. Dit leverde geen relevante meetinstrumenten op. De zoektocht in Cochrane leverde één systematische review op betreffende interventies voor 
zorgverleners teneinde vraaggerichte zorg te verbeteren (Lewin et al., 2001). Vraaggerichte zorg (patient-centred care) was in deze studie gedefinieerd als: 'A philosophy of care that encourages: a) a shared control of the consultation, decisions about interventions or management of the health problems with the patient, and/or b) a focus in the consultation on the patient as a whole person who has individual preferences situated in a social context.' Lewin et al. . concluderen dat er momenteel geen 'gouden standaard' is om patient-centred care te meten. Effectmaten (outcomes) van cliëntgerichtheid werden gezocht in humaniteit, het bevestigen en bemoedigen van de cliënt en het geven van informatie en gepercipieerde communicatie en de mate van overeenstemming tussen cliënt en zorgverlener betreffende de zorg. De review betrof 17 studies bij (para)medische en verpleegkundige zorgverleners. Twee van de onderzochte studies betroffen alleen verpleegkundigen (Kinmonth et al., 1998; Pill et al., 1998). In geen van de door Lewin et al. geselecteerde studies werd vermeld of de cliënt betrokken was geweest bij het vaststellen van effectmaten. Een aanvullende, vergelijkbare zoektocht in CINAHL leverde 1593 treffers op. Na afbakening met de trefwoorden 'nursing', 'home care', en 'measurement' (inclusief synoniemen als scale, questionnaire en test) resteerden 26 bronnen. De gevonden meetinstrumenten betroffen kwaliteit van leven, kwaliteit van zorg, aspecten van participatie en casemanagement. Er werd geen bestaand meetinstrument gevonden om competenties voor vraaggerichte zorg in de thuiszorg mee te meten. Naar aanleiding van de literatuurstudie werd besloten zelf een instrument te ontwikkelen in samenspraak met centrale belanghebbenden: chronisch zieke cliënten, hun mantelzorgers, zorgverleners en managers in de thuiszorg.

\section{Instrumentontwikkeling}

De ontwikkeling van het meetinstrument is gebaseerd op een kwalitatief onderzoek naar het perspectief van centrale belanghebbenden op vraaggerichte zorg. Dit werd verkend door middel van open interviews met cliënten (2), managers van zorgorganisaties (3), verzekeraars (2) en zorgverleners (1). Gezien de centrale rol van de cliënt werd het clientenperspectief op vraaggerichte zorg alsmede het perspectief op gewenste competenties van zorgverleners verder verhelderd met behulp van focusinterviews met ervaringsdeskundige cliënten en mantelzorgers (Schoot et al., 2005a). Hierna volgden participerende observaties (45 cliëntsituaties) en semi-gestructureerde interviews met cliënten (6) en met verpleegkundigen en verzorgenden bij drie thuiszorgorganisaties (9) (Schoot et al., 2005b; Schoot et al., 2006a). De bevindingen werden voorgelegd aan de ontwerpers van een leertraject 'vraaggerichte zorg', aan een stuurgroep (bestaande uit bestaande uit leden van de cliëntenraad van drie thuiszorgorganisaties, managers van deze thuiszorgorganisaties, en medewerkers van twee provin- 
ciale patiëntenorganisaties) en aan een klankbordgroep bestaande uit vertegenwoordigers van diverse koepelorganisaties, zoals de Landelijke Vereniging voor Thuiszorg, de landelijke Vereniging voor Wijkverpleegkundigen, het Landelijk Expertisecentrum Verpleging en Verzorging, Sting, de beroepsvereniging voor verzorgenden en de Chronisch Zieken en Gehandicapten Raad (Schoot et al., 2004). Een samenvatting van de bevindingen uit het kwalitatieve onderzoek werd gepresenteerd aan de leden van de stuurgroep en aan de ontwerpers van een leertraject 'vraaggerichte zorg'. Aansluitend werd in samenspraak met hen de volgende werkdefinitie van vraaggerichte zorg vastgesteld:

- Vraaggerichte zorg is zorg die uitgaat van de wensen en ervaren behoeften van de zorgvrager, in dialoog tot stand komt en waarbij de zorgvrager uiteindelijk beslist.

Tevens werden de volgende doelen van vraaggerichte zorg op cliëntniveau vastgesteld:

- De zorgvrager geeft aan door de zorgverlener serieus genomen te worden en gerespecteerd te worden.

- De zorgvrager geeft aan autonomie te ervaren ten aanzien van de wijze waarop vormgegeven wordt aan de zorg.

Vervolgens werd in drie consensusronden een conceptset van drie competenties voor vraaggerichte zorg vastgesteld door de ontwerpers van het leertraject, de stuurgroep en de klankbordgroep. De competenties werden aansluitend geoperationaliseerd door de onderzoekers tot een self-assessmentschaal: de 'Zorg in dialoog Competentie Schaal' (Zie Tabel 1). In de items en de antwoordmogelijkheden werd conform de definitie van 'competentie' de nadruk gelegd op de uitvoering van werkzaamheden en het vertonen van bepaald gedrag in de praktijk.

Deze schaal werd voor commentaar voorgelegd aan de managers van de thuiszorgorganisaties (3); aan een stafmedewerker van Sting (de beroepsvereniging van de verzorging) aan de ontwerpers van het leertraject (4) en aan enkele zorgverleners uit de praktijk (3).

\section{Beschrijving van het instrument}

De 'Zorg in dialoog Competentie Schaal' is een zelfbeoordelingsschaal voor verpleegkundigen en verzorgenden werkzaam in de thuiszorg bij chronisch zieken. De schaal is bedoeld om inzicht te krijgen in de eigen competenties met betrekking tot vraaggerichte zorg. De schaal bestaat uit drie delen. Ieder deel betreft de operationalisatie van één van de drie vastgestelde competenties met betrekking tot vraaggerichte zorg. Competentie 1 betreft het zorgproces in dialoog, competentie 2 betreft ondersteuning van cliëntparticipatie, en competentie 3 betreft het hanteren van spanningsvelden. Competentie 1 werd geopera- 
tionaliseerd in een schaal bestaande uit 18 gedragsitems, competentie 2 werd geoperationaliseerd in 10 gedragsitems, en competentie 3 in 8 gedragsitems. Gebruikers van de schaal wordt gevraagd om voor ieder van de gedragsitems aan te geven in hoeverre het op henzelf van toepassing is tijdens de zorgverlening aan cliënten. De antwoordmogelijkheden zijn aangegeven op een vierpunts Likert Schaal: $1=$ eigenlijk niet; $2=$ in beperkte mate; $3=$ regelmatig; $4=$ heel vaak.Via een aantal open vragen konden de participanten reageren op de items uit de vragenlijst, en aanvullende opmerkingen maken.

\section{Pilotstudie}

Erwerd een pilotstudie uitgevoerd bij 74 verpleegkundigen en verzorgenden van vier thuiszorgorganisaties in het zuiden van Nederland. Selectie vond plaats op basis van deelname aan geplande bijscholingsbijeenkomsten (convenience sampling). Alle participanten waren zorgverlener van mensen met een chronische ziekte. De participanten waren opgeleid op kwalificatieniveau 5, 4 en 3 Individuele Gezondheidszorg (IG).

\section{Procedure}

Het onderzoek werd getoetst conform de gedragscode gezondheidszorgonderzoek door de Medisch-ethische Toetsingscommissie te Hoensbroek, en werd positief en relevant bevonden. Participanten werden geïnformeerd conform de procedure. De anonimiteit van de metingen werd gegarandeerd. Deelname aan het onderzoek gebeurde op vrijwillige basis.

\section{Data-analyse}

Het streven was om unidimensionele en compacte schalen met een hoge interne consistentie te verkrijgen. De analyses werden uitgevoerd per schaal. Teneinde items te identificeren die een zwakke bijdrage leverden aan de betreffende schaal, werd een principale componentenanalyse uitgevoerd voor ieder van de drie schalen. Als 'zwakke bijdrage' gold een factorlading $<, 40$ op de eerste factor. Cronbach's alpha's werden per schaal berekend om inzicht te verkrijgen in de interne consistentie van de schalen. Op geleide van deze analyses werd een aantal 'zwakke' items verwijderd. Vervolgens werd opnieuw de interne consistentie berekend.

Met het oog op de validiteit van de schalen werd nog een aantal aanvullende analyses verricht. Er waren geen redenen om verschillen te verwachten in de gemiddelde somscore per competentie tussen de organisaties. Deze hypothese werd getoetst met een ANOVA-test. Hiertoe werd eerst de somscore berekend per individuele deelnemer door per deelnemer de scores op de afzonderlijke 
items per competentie op te tellen. De theoretische range bedroeg 14-56 voor competentie 1, 7-28 voor competentie 2, en 8-32 voor competentie 3. Vervolgens werd een gemiddelde somscore per competentie per organisatie berekend door de individuele somscores op te tellen en te delen door het aantal deelnemers per organisatie. Er werden eveneens geen correlaties verwacht tussen de individuele somscores en de achtergrondkenmerken van de deelnemers. De correlaties werden berekend met Pearson's correlatie coëfficiënt.

\section{RESULTATEN}

\section{De onderzochte groep}

Tussen eind 2003 en begin 2005 vonden de metingen plaats in vier thuiszorgorganisaties. Het aantal deelnemers van de afzonderlijke organisaties bedroeg respectievelijk 9, 12, 13 en 38. De gemiddelde leeftijd van de participanten was 38 jaar (range 21-58 jaar). Er namen zes mannen deel aan de metingen. Zes participanten waren verzorgende IG, acht participanten waren verpleegkundige niveau 4 en de overige participanten (58) waren verpleegkundigen niveau 5 . Het aantal jaren ervaring in de organisatie was minder dan 1 jaar voor 8 participanten, 1-3 jaar voor 14 participanten, en langer dan 3 jaar voor 50 participanten. Het aantal gewerkte uren per week was gemiddeld 28,7 (range 18-40).

\section{Constructvaliditeit en interne consistentie}

Voor alledrie de schalen gold dat het merendeel van de items hoge factorladingen $(\geq, 40)$ op de eerste factor had (zie Tabel 1). De items met de hoogste ladingen betroffen de kern van een betreffende competentie zoals bedoeld. Zeven items van schaal 1 hadden een factorlading $<, 40$ en $\geq, 30$ op de eerste factor. Bij schaal 2 hadden drie items een factorlading $<.40$. Bij schaal 3 waren alle ladingen op de eerste factor $\geq, 40$. Alle items met een lagere factorlading werden verwijderd met uitzondering van drie van de items van schaal 1 betreffende de besluitvorming in dialoog met de cliënt (item 9, 10 en 12). De factorlading van deze drie items was $<, 40$ en $\geq$,30. De verwijderde items leken bij nadere beschouwing deels coördinatie van zorg te betreffen, en vertoonden overlap met schaal 3. Na verwijdering van item 2, 3, 17 en 18 van schaal 1 en item 7, 9 en 10 van schaal 2 werd opnieuw een principale componentenanalyse uitgevoerd. Alle resterende items (met uitzondering van de drie genoemde items) toonden nu een factorlading $\geq, 40$ op de eerste factor. De interne consistentie (Cronbach's alpha) van de drie schalen na bewerking was ,81 voor schaal 1; ,78 voor schaal 2; en ,74 voor schaal 3 (zie Tabel 1). 
Tabel 1. Interne consistentie van de 'Zorg in dialoog Competentie Schaal' voor en na verwijdering van items

\section{Competentie 1: Zorgproces in dialoog}

01. Ik ben me bewust van het effect van mijn manier van contact leggen op de relatie met de cliënt

02. Ik ben in staat mijn taalgebruik af te stemmen op de cliënt

03. Ik ben in staat mijn omgangsvormen af te stemmen op de omgangsvormen van de cliënt, zolang deze niet in strijd zijn met de geldende normen

04. Ik geef de cliënt gelegenheid zorgvragen te stellen, zolang deze niet in strijd zijn met de geldende normen

05. Ik ondersteun de cliënt bij het stellen van zorgvragen en check na of we , elkaar begrijpen

06. Ik geef de cliënt advies over de zorgvragen

\begin{tabular}{|c|c|}
\hline voor & na \\
\hline ,45 & ,49 \\
\hline, 34 & verw. ${ }^{1}$ \\
\hline, 35 & verw. \\
\hline, 55 & ,46 \\
\hline ,68 & ,67 \\
\hline, 70 & ,71 \\
\hline ,61 &, 59 \\
\hline ,60 & ,61 \\
\hline ,30 &, 33 \\
\hline, 36 &, 36 \\
\hline ,63 & ,65 \\
\hline ,30 &, 32 \\
\hline, 56 &, 58 \\
\hline ,64 & ,67 \\
\hline, 55 &, 53 \\
\hline, 51 & ,47 \\
\hline ,37 & verw. \\
\hline, 39 & verw. \\
\hline 4,699 & 4,148 \\
\hline 26,1 & $29,7 \%$ \\
\hline, 81 & ,81 \\
\hline
\end{tabular}

07 . Ik stel de cliënt in de gelegenheid om ook elders adviezen in te winnen over de zorgvragen

08. Ik stimuleer de cliënt om zelfstandig besluiten te nemen over het zorgplan

09. Ik neem samen met de cliënt besluiten over het tijdstip waarop de zorg zal worden verleend

10. Ik neem samen met de cliënt besluiten over wie de zorg zal verlenen

11. Ik neem persoonlijke wensen en voorkeuren van de cliënt serieus

12. Ik respecteer de keuzes/besluiten van de cliënt (ook als ik het daar niet mee eens ben)

13. Vanuit mijn professionele kennis kan ik mijn twijfels over keuzes/besluiten met respect voor de cliënt kenbaar maken

14. Uit het zorgplan blijkt dat de behoeften/wensen en doelen van de cliënt centraal staan

15. Bij de uitvoering van de zorg pas ik mij aan de wensen en mogelijkheden van de cliënt

16. Ik evalueer regelmatig het zorgplan en de uitvoering van de zorg met de cliënt

17. Ik bespreek regelmatig het zorgplan van de cliënt met mijn collega's om op deze wijze de zorg aan de cliënt doorlopend te continueren

18. Ik kan over mijn grenzen en mogelijkheden op een professionele wijze communiceren

\section{Eigenvalue}

Verklaarde variantie

Cronbach's alpha

\section{Competentie 2: Ondersteuning van cliënt- participatie}

01. Ik ben me ervan bewust dat de vraag van de cliënt uitgangspunt is voor _, 49 , 47 de te verlenen zorg

02. Ik stimuleer de cliënt om eigen kennis en ervaring in te brengen tijdens , ,67 , , , , , het zorgproces

03. Ik stimuleer de cliënt om zelf verantwoordelijkheid te nemen voor het $\quad$,68 , , , , zorgproces $\begin{array}{lll}\begin{array}{l}\text { 04. Ik stimuleer de cliënt om actief sturing te geven aan het zorgproces en } \\ \text { beslissingen te nemen over (dagelijkse) zorgactiviteiten; }\end{array} & , 74\end{array}$ 
05. Ik stimuleer de cliënt om zelf de zorg te regelen en te organiseren $\quad, 75 \quad, 78$

06. Ik ondersteun en bemoedig de cliënt bij zijn/haar initiatieven $\quad, 75 \quad, 75$

07. Ik signaleer knelpunten in het zorgproces en bespreek oplossingen en ,36 verw. alternatieven met de cliënt

08. Ik pas het zorgplan aan aan de veranderende wensen en zorgvragen van $\quad$, 47 $\quad$,0 de cliënt

09. Ik bespreek het bijgestelde zorgplan met collega's om de continuïteit ,32 verw. van het zorgproces te waarborgen

10. Ik neem geen zaken van de cliënt over die hij zelf wil of kan doen $\quad, 30 \quad$ verw.

Eigenvalue $\quad 3,363 \quad 3,094$

Verklaarde variantie $\quad 33,6 \% \quad 44,2 \%$

$\begin{array}{lll}\text { Cronbach's alpha } & , 72 & , 78\end{array}$

\section{Competentie 3: Omgaan met spanningsvelden}

De verpleegkundige zoekt actief naar alternatieve mogelijkheden op het moment dat persoonlijke, professionele en organisatorische grenzen zich voordoen

01. Ik ben mij bewust van organisatorische mogelijkheden en beperkingen en kan op $\quad, 70$ basis hiervan verbeteracties formuleren

02. Ik ben me bewust van mijn persoonlijke en professionele mogelijkheden en $\quad$,60 beperkingen en kan op basis hiervan verbeteracties formuleren

03. Ik geef duidelijkheid aan de cliënt over organisatorische en mijn persoonlijke $\quad$,49 mogelijkheden en beperkingen

04. Ik zoek actief naar alternatieve mogelijkheden om aan de zorgvraag van de cliënt , 66 tegemoet te komen bij persoonlijke, professionele of organisatorische grenzen

05. Ik ondersteun collega's bij het zoeken naar alternatieve mogelijkheden om aan de , 68 vraag van de cliënt tegemoet te komen bij persoonlijke, professionele of organisatorische grenzen

06. Ik draag zorg voor de randvoorwaarden in de organisatie die de eigen regie van de ,61 cliënt ondersteunen

07. Ik sta open voor kritiek van de cliënt $\quad, 49$

08. Ik sta open voor kritiek van collega's

Eigenvalue $\quad 2,793$

$\begin{array}{ll}\text { Verklaarde variantie } & 34,9 \%\end{array}$

$\begin{array}{ll}\text { Cronbach's alpha } & \text {,74 }\end{array}$

1 Verw. = verwijderd uit de schaal

De gemiddelden van de somscores van de afzonderlijke organisaties op de drie bewerkte schalen werden vergeleken met een ANOVA-test. Er werden geen significante verschillen gevonden (zie Tabel 2). De correlaties van de individuele somscores met de achtergrondvariabelen van de participanten werden berekend met behulp van Pearson's correlatiecoëfficiënt. Er werden geen significante correlaties gevonden (zie Tabel 3). 
Tabel 2. De gemiddelde somscores per competentie en per organisatie

Gemiddelde somscore competentie 1 organisatie A, B, C, D

Gemiddelde somscore competentie 2 organisatie A, B, C, D

Gemiddelde somscore competentie 3 organisatie A, B, C, D
46 / 48,7 / 46,3 / 45,7

23,7 / 23,6 / 24,3 / 22,8

25,5 / 25,1 / 26,2 / 24,7
Sig. ,439

Sig. ,371

Sig. , 467

Tabel 3. Correlaties per competentie tussen individuele somscores en achtergrondvariabelen

$\begin{array}{lcccc}\text { Competentie } & \text { leeftijd } & \text { opleidingsniveau } & \text { omvang anstelling } & \text { ervaring } \\ 1 & , 07 & , 05 & , 02 & , 08 \\ 2 & , 09 & , 01 & , 03 & , 01 \\ 3 & -, 08 & -, 1 & -, 02 & , 07 \\ (p .>0,05) & & & & \end{array}$

\section{Bruikbaarheid}

De reacties op de open vragen maakten duidelijk dat de schaal aanzet tot bewustwording van en reflectie op het eigen gedrag en tot competentieontwikkeling, getuigen enkele opmerkingen van respondenten:

'Bij sommige vragen wist ik het eigenlijk niet zo goed. Ik ga er beter op letten of ik dat wel doe.'

'Het zette me aan het denken over mijn eigen functioneren.'

Respondenten beoordeelden de zelfbeoordelingsschaal als gebruiksvriendelijk. De geboden waarborgen voor anonimiteit werden als voldoende veilig ervaren. Het invullen nam ongeveer 15 minuten in beslag. Er waren geen onduidelijke items.

\section{DISCUSSIE}

Het doel van deze studie was de ontwikkeling van een meetinstrument om inzicht te krijgen in de eigen competenties voor vraaggerichte zorg. De 'Zorg in dialoog Competentie Schaal' is gebaseerd op kwalitatief onderzoek naar het cliëntenperspectief en het perspectief van verpleegkundigen en verzorgenden op vraaggerichte zorg. In de studie werd veel aandacht besteed aan de inhoudsvaliditeit. Op basis van bevindingen uit dit onderzoek werden in samenspraak met cliënten, verpleegkundigen en verzorgenden en hun managers drie competenties voor vraaggerichte zorg geformuleerd en geoperationaliseerd. Met behulp van principale componentenanalyse werd het oorspronkelijke aantal items enigszins 
gereduceerd. Met uitzondering van enkele items bleken de drie schalen unidimensioneel. Drie items betreffende besluitvorming in dialoog werden ondanks factorladingen $<, 40$ op inhoudelijke gronden behouden.

Er zijn enkele kanttekeningen bij dit onderzoek te plaatsen. Ten eerste wat betreft de principale componenten analyse. Op basis van het aan de studie voorafgaande kwalitatieve onderzoek werden drie kerncompetenties vastgesteld en geoperationaliseerd. Deze vormden het vertrekpunt van de analyse. De omvang van de steekproef bij de principale componenten analyse was wat betreft de competenties 2 en 3 zeven maal het aantal items, hetgeen beperkt is, maar acceptabel. Een beperking is dat bij competentie 1 de steekproef te klein is voor het aantal items.

Een tweede kanttekening betreft het besluit om enkele items op inhoudelijke gronden te behouden, ook al wezen statistische bevindingen in een andere richting. De drie items die werden behouden vormen een essentiële component van vraaggerichte zorg, namelijk besluitvorming in dialoog. Betreffende items werden met name door de cliënten die betrokken waren bij de ontwikkeling van het instrument zeer belangrijk gevonden in het kader van de betreffende competentie. Nader onderzoek hiernaar wordt aanbevolen. Een ander argument voor handhaving van betreffende items is dat een factorlading van $<, 30$ in de literatuur als cut-off point wordt genoemd (Polit \& Hungler, 1995). De betrouwbaarheid van de schaal bleek met handhaving van de betreffende items gelijk te blijven. Een derde kanttekening betreft de zelfbeoordeling van competenties. Rapmund en Wijnen (1994) stellen dat het gebrek aan competenties voor degene die zich hier niet bewust van is, onzichtbaar blijft. Zij beschrijven in dit kader vier stadia van (on)bewust (on)bekwaamheid. Een evaluatieve studie naar de impact van competentieontwikkeling rond vraaggerichte zorg, met het beschreven instrument waaraan een procesevaluatie was toegevoegd, leverde diverse aanwijzingen dat er bij respondenten sprake was van een omslag van onbewust onbekwaamheid naar bewuste bekwaamheid (Schoot et al 2006). Bewustzijn van de noodzaak tot veranderen is een voorwaarde voor gedragsverandering en voor competentieontwikkeling. In dit opzicht vormt het instrument een essentieel element van het veranderingsproces. Er is getracht de gevoeligheid van het instrument voor normverschuiving ten gevolge van opleiding te voorkomen door te vragen naar concreet gedrag. Assessment kan bij bepaalde mensen als zeer bedreigend overkomen en daardoor weerstanden oproepen. Mensen proberen zich te beschermen tegen negatieve kritiek. Sociale wenselijkheid is de geneigdheid van de persoon om een gunstig beeld van zichzelf te scheppen, dat overeenkomt met de geldende moraal (Polit en Hungler, 1995). Genoemde overwegingen spelen een rol bij de beoordeling van de validiteit van het instrument voor evaluatieve doeleinden. De verwachting is dat, mits voldoende garanties voor de bescherming van anonimiteit zijn gecreëerd en onder voorwaarde 
van herhaalde metingen, zelfbeoordeling van competenties een geschikte bijdrage kan leveren aan effectevaluatie.

De vraag rijst of een complex en contextueel afhankelijk concept als vraaggerichte zorg meetbaar is. Met het ontwikkelde instrument is gepoogd recht te doen aan de dimensies en het contextgebonden karakter van vraaggerichte zorg. Voorzichtigheid is echter geboden bij het interpreteren van de resultaten. Daarnaast wordt aanbevolen om ook kritisch te reflecteren op de geboden zorg en op de zorgrelatie met de cliënt. De elementen van de ontwikkelde schaal kunnen gebruikt worden als een hulpmiddel hierbij.

Het aantal verzorgenden IG (6) dat betrokken was bij de test van het instrument was gering. Nader onderzoek naar het hanteren van de vragenlijst door deze groep wordt aanbevolen. De beperking van het aantal deelnemende mannen en de beperking tot vier thuiszorgorganisaties in het zuiden van Nederland heeft naar ons idee geen gevolgen voor de bruikbaarheid en validiteit van het instrument. De constructvaliditeit wordt gedeeltelijk onderbouwd met het aantonen van de afwezigheid van relaties. Het gevaar van deze redenering is dat indien het instrument niets meet, omdat het niet valide en/ of niet betrouwbaar is, deze relaties ook zullen uitblijven. Een vraag is in hoeverre het meetinstrument in staat is om veranderingen te meten. Een evaluatieonderzoek waarbij de betreffende schaal gebruikt werd laat veelbelovende resultaten zien (Schoot et al., 2006b). Verder onderzoek naar de responsiviteit van het meetinstrument zal moeten uitwijzen hoe het hiermee gesteld is.

Gesteld werd dat er geen redenen waren om verschillen te verwachten tussen de competenties van de zorgverleners van de diverse instellingen. Deze uitspraak werd gebaseerd op de afwezigheid van opleidingsactiviteiten rond vraaggerichte zorg in de diverse instellingen. Tevens werd gesteld dat er geen correlaties verwacht werden tussen scores en achtergrondkenmerken, zoals opleidingsniveau. Vraaggerichte zorg is een complex proces, en er mag worden verwacht dat beter opgeleiden het er beter van af brengen. Echter, een inventarisatie van het reguliere opleidingsaanbod voor verplegenden en verzorgenden maakte duidelijk dat er in de diverse basisopleidingen weinig expliciete aandacht werd besteed aan competenties voor vraaggerichte zorg.

De verwachting is dat het instrument, met relatief kleine aanpassingen aan de zorgsetting, ook valide en bruikbaar is voor andere sectoren dan de thuiszorg en voor andere patiëntencategorieën dan chronisch zieke cliënten.

De mate van vraaggerichtheid van de organisatie waarin de zorgverlener werkt is in deze studie buiten beschouwing gelaten.

Gaandeweg de dataverzameling werd een enigszins vergelijkbaar instrument gevonden, namelijk de Client-Centred Process Evaluation (CCPE) (Restall et al., 2003). Dit instrument is ontwikkeld als hulpmiddel voor professionals (ergotherapeuten en verpleegkundigen) in Canada, teneinde hen te ondersteunen bij 
de bevordering van cliëntgerichte zorg. Het instrument bestaat uit vijf onderdelen, waaronder een evaluatie van het therapeutische proces en de relatie met de cliënt. Ondanks de veelbelovende mogelijkheden van dit instrument wordt het slechts gedeeltelijk geschikt geacht voor chronisch zieken die langdurig zorg ontvangen, omdat een aanzienlijk deel van de items van dit instrument behandeling betreft, terwijl bij de zorg voor mensen met een chronische ziekte vaak eerder de nadruk ligt op het leven met de aandoening.

\section{CONCLUSIES EN AANBEVELINGEN}

In dit artikel werd de ontwikkeling en het testen van de 'Zorg in dialoog Competentie Schaal' beschreven, een meetinstrument voor zelfbeoordeling van vraaggerichtheid van de geboden zorg. Voor elk van de drie competenties: dialoog met de cliënt, ondersteuning van cliëntparticipatie en omgaan met spanningsvelden, werd een intern consistente schaal verkregen. De constructvaliditeit, interne consistentie en bruikbaarheid bleken voldoende tot goed te zijn.

Zorgverleners hebben er belang bij om inzicht te verwerven in hun competenties. Dit instrument kan een hulpmiddel zijn bij het vaststellen van opleidingsbehoeften en persoonlijke ontwikkeltrajecten. Het instrument lijkt eveneens relevant voor beleidsmakers en managers, en voor andere sectoren, zoals verpleeghuiszorg. Een andere gebruiksmogelijkheid van het instrument is een bijdrage leveren aan het vaststellen van het effect van interventies gericht op de bevordering van vraaggerichte zorg. Het verdient in dat geval aanbeveling om naast het ontwikkelde instrument op competentieniveau van de zorgverlener, ook een instrument voor het meten van de door de cliënt ervaren vraaggerichtheid van de zorg te gebruiken.

Voorzichtigheid bij het interpreteren van de resultaten en aanvullende kritische reflectie wordt aanbevolen.

Verder onderzoek gericht op het testen van de validiteit, betrouwbaarheid en responsiviteit van het meetinstrument, met name bij zorgverleners van niveau 3IG en bij zorgverleners in andere sectoren dan de thuiszorg, wordt aanbevolen.

\section{DANKWOORD}

Wij danken de ontwerpers, stuurgroep en klankbordgroep van het leertraject 'Zorg in dialoog' en alle verpleegkundigen, verzorgenden en managers van de thuiszorgorganisaties die betrokken waren bij dit onderzoek voor hun bijdrage. Wij danken de medewerkers van Bureau Onderzoeksverwerking van de Hogeschool Zuyd voor hun ondersteuning.

Dit onderzoek werd mede mogelijk gemaakt door financiële steun van de Hogeschool Zuyd. 


\section{SUMMARY}

The purpose of this article is to describe and discuss the development and testing of the 'care in dialogue competence scale', for home care nurses and auxiliary nurses. This self assessment scale aims at measuring competencies for clientcentered care to chronically ill clients receiving home care. The instrument was developed on the basis of qualitative research into the client's perspective and the nurse's perspective of client-centred nursing home care. Client representatives, caregivers and their managers were systematically involved in identifying the competencies needed for client-centred care. Three competencies needed for client-centred care were operationalized into three scales of 18, 10 and 8 items. A pilot study was conducted with a sample of 74 nurses and auxiliary nurses, caring for chronic ill clients of four home care organizations in the south of the Netherlands. Respondents varied in gender, education level (3IG, 4 and 5), age, experience and number of working hours. The internal consistency of the scales was studied by using principal component analysis and by calculating Cronbach's alpha. The majority of the items showed high factor loadings on the first factor. Items with a factor loading $<.40$ were removed from the scale. Three items with a factor loading $<.40$ and $\geq .30$ on the first factor were retained based upon their content. Internal consistency analysis showed acceptable to good internal consistency for the remaining items (Cronbach's alpha competency $1=.81$, competency $2=.78$, competency $3=.74$ ). As expected, no significant differences were found between mean sumscores of the competencies in each home care organization, and no correlations were found between individual sumscores and the background variables. The construct validity, internal consistency and feasibility of the adapted 'care in dialogue competence scale' appeared to vary from acceptable to good. The instrument offers possibilities for evaluation and self-reflection with respect to client-centred care. Further testing of the reliability, validity and responsiveness of the instrument is recommended.

\section{LITERATUUR}

Cahill J. Patient participation: A review of the literature. Journal of Clinical Nursing 1998; 7: 119-128.

De Klaver PM, Scholten C. De vraag naar Thuiszorg: Literatuurstudie naar voorbeelden van (meer) vraaggestuurde thuiszorg. Leiden; 2002.

Goudriaan G, Vaalburg AM. De vraag als maat. Utrecht: Nederlandse Patiënten/ Consumentenfederatie (NP/CF) en het Nederlands Instituut voor Zorg en Welzijn (NIZW); 1998.

Habets HPJM, Koning CC (Eds). Jaarboek Verpleegkunde 1999 'Vraaggerichte Zorg'. Dwingeloo: Kavanah; 1999. 
KITTZ/RBO. Sprong naar Vraaggericht denken en handelen. Groningen: KITTZ; 2004.

Kinmonth AL, Woodcock A, Griffin S, Spiegal N, Campbell MJ. Randomised contolled trial of patient centred care of diabetes in general practice:impact on current wellbeing and future disease risk. British Medical Journal 1998; 8: 1202-1208.

Latvala, E. Developing and testing methods for improving patient-oriented mental health care. Journal of Psychiatric and Mental Health Nursing 2002; 9: 41-47.

Leistra E, Liefhebber S, Geomini M, Hens H. Beroepsprofiel van de verpleegkundige. Maarssen/ Utrecht: Elsevier/De Tijdstroom en LCVV; 1999.

Lewin SA, Skea ZC, Entwistle V, Zwarenstein M, Dick J. Interventions for providers to promote a patient-centred approach in clinical consultations. Cochrane Review; 2001.

Pill R, Scott NCH, Rollnick SR, Rees MA. A randomized controlled trial af an intervention designed to improve the care given in general practice to type II diabetic patients: patient outcomes and professional ability to change behaviour. Family Practice 1998; 3: 229-235.

Polit F, Hungler BP. Nursing Research: principles and methods. Philadelphia: J.P.Lippincott Company; 1995.

Rapmund R., Wijnen G. Een handvol groei-en leermiddelen voor professionals. In JWM Kessels, CA Smit (Eds.). Opleiders in organisaties: Capita Selecta; Vol. 20: Kluwer Bedrijfswetenschappen; 1994.

Restall G, Ripat J, Stern M. A framework of strategies for client-centred practice. Canadian Journal of Occupational Therapy 2003; 70(2): 103-112.

Rijckmans MJM, Garretsen HFI, Bongers IMB, Van de Goor LAM. Vraaggerichtheid en vraagsturing. Een poging tot conceptuele verheldering. Tijdschrift voor Sociale Gezondheidszorg 2002; 80: 388-392.

Ruwaard D, Kramers PGN. Volksgezondheid toekomst verkenning 1997: de som der delen. Bilthoven: Elsevier/ De Tijdstroom; 1997.

Ruwaard D, Van den Berg Jeths A, Gijsen R. Demografie van chronisch ziek Nederland. In G.A.M. van den Bos, B.W. Frijling, Y. Koster-Dreese, P. Schnabel \& C. Spreeuwenberg (Eds.), Chronisch-ziekenbeleid in de jaren negentig. Utrecht: Uitgeverij SWP; 1999.

RVZ. Naar een meer vraaggerichte zorg. Zoetermeer: Raad voor de Volksgezondheid; 1998.

Schoot T, Engels J, Hollands L, De Witte L. Het ontwerp van een leertraject in samenspraak. Onderwijs en Gezondheidszorg 2004; 6: 3-10.

Schoot T, Proot I, Ter Meulen R, De Witte L. Recognition of client values as a basis for tailored care: the view of Dutch expert patients and family caregivers. Scandinavian Journal of Caring Sciences 2005a; 19: 169-176.

Schoot T, Proot I, Ter Meulen R, De Witte L. Actual interaction and client-centredness in home-care. Clinical Nursing Research 2005b; 14 (4): 370-393.

Schoot T. Proot I, Legius, M, Ter Meulen R, De Witte L. Client-centred home care: Balancing between competing responsibilities. Clinical Nursing Research 2006a; 15(4):1-24.

Schoot T, Hirsch M, De Witte L. Development of competencies aimed at client-centred care: An evaluation study of an educational programme for nurses and auxiliary nurses 2006b; Submitted. 
Tillema H. Inzicht in competentie-ontwikkeling. Ervaringen met de invoering van performance-assessment instrumenten in organisaties. Opleiding \& Ontwikkeling 1997; 10(6): 21-24.

Van der Kraan WGM. Vraaggericht en vraaggestuurd: Een literatuuronderzoek naar vraaggerichtheid en vraagsturing in de gezondheidszorg. Den Haag: ZONMw en Erasmus Universiteit Rotterdam; 2001.

Verbeek, G, Tiemersma K. Aan elkaar gewaagd? Oriëntatie op het samenspel tussen cliënt en zorgverlener in een vraaggerichte zorg. Utrecht: NIZW; 1998.

WHO. European Health Care Reforms. Citizens' Choice and Patients' Rights. Copenhagen: World Health Organization Regional Office for Europe; 1996.

VWS. Zicht op Zorg: Planvan Aanpak Modernisering. Den Haag: Ministerie van VWS; 1999.

ZonMw. Op andere gedachten. Den Haag: ZonMw; 2004. 



\section{DEVELOPMENT OF THE CLIENT- CENTRED CARE QUESTIONNAIRE}

De Witte, L. P., Schoot, T., \& Proot, I. P. (2006).

Accepted for publication april 2006 by Journal of Advanced Nursing 


\section{ABSTRACT}

Aim: This paper presents the development and testing of the Client-Centred Care Questionnaire, aimed at evaluating the client-centredness of professional home nursing care from a client perspective.

Background: Client-centred care has become an important theme in healthcare. To evaluate the client-centredness of care and services from a client's perspective, there is a need for measurement instruments.

Method: The questionnaire was developed on the basis of a qualitative study into the client perspective on home nursing care. Items were formulated that closely followed the aspects clients mentioned as central to client-centred home care. A pilot study was conducted with a sample of 107 clients of three home care organizations in 2003 and 2004. These clients had chronic diseases and were expected to receive care for at least another six months. The questionnaire comprises 15 items.

Findings: Principal components analysis and internal consistency analysis show strong internal consistency of the items. All items have strong factor loadings on one dimension, and Cronbach's alpha was 0.94. Clients tended to be most critical about their say in the practical arrangements and organization of care: which person comes, how often and when? Clients of the three home care organizations differ in their perception of client- centredness, which may indicate that the questionnaire is capable of differentiating between respondents.

Conclusion: The results of this pilot study are promising. The validity of the questionnaire needs further testing.

Keywords: client-centred care, patient-centred care, client perspective, patient participation, nursing, home care, instrument development

\section{SUMMARY}

What is already known on this topic?

Client-centred care is becoming an important theme in healthcare in most western countries

Evaluation of client-centredness from a client perspective is increasingly important

No measurement instruments for such evaluation have been published

What this study adds

A short questionnaire to measure the client-centredness of professional nursing in home care from a client perspective was developed and tested: the ClientCentred Care Questionnaire

Home care organizations can use this questionnaire to evaluate their services The responses of clients give clues for improving client-centredness 


\section{INTRODUCTION}

Most western countries have witnessed a shift towards client-centred care (Cahill 1998, Watersworth and Luker 1990, Sainio et al. 2001). In the Netherlands too client-centred care has become an important theme in healthcare. Client-centred care aims at care that optimally fits the needs and demands of individual clients (Goudriaan and Vaalburg 1998, VWS 1999, Restall, Ripat and Stern 2003). It has been defined as an approach to providing services that embraces a philosophy of respect for, and partnership with people receiving services (Law, Baptiste and Mills 1995). Care that optimally fits the needs and demands of the individual client can be positioned in a tradition of nursing and nursing sciences, inspired by authors like Benner (1984), King (1981), Koene et al (1982) and Patterson and Zderad (1976). There is a growing acceptance in healthcare settings that a clientcentred approach has a positive impact on outcomes and has thus become essential. But, according to several experts (Sumsion 2002, Restall, Ripat and Stern 2003), healthcare professionals still continue to have problems implementing client-centred practice, particularly for clients with chronic conditions, who experience a lack of client-centredness in care and services (CG-raad 2002, de Witte et al. 2003).

In the Netherlands, there is a growing call to evaluate care organizations from a client perspective, and to publish such evaluations in order to provide (potential) clients with relevant information that helps them choose between different care providers or healthcare organizations. The national government has initiated the development of an internet portal for this particular purpose (www.kiesBeter.nl). Many healthcare organizations are working on implementing client-centred care concepts into daily practice. To evaluate the client-centredness of care and services from a client's perspective, however, there is a need for short and feasible measurement instruments. The aim of this study was to develop a questionnaire enabling the evaluation of client-centredness as experienced by clients of different organizations, and the effects of interventions aimed at improving client-centredness of care and services.

\section{LITERATURE REVIEW}

Before deciding to develop a new questionnaire, the literature was reviewed for measures already available. To find possibly usable measures, the Pubmed database was searched for publications about instruments that measure clientcentredness. The search period was the five years to April 2005. Search terms were: patient-centred care, client-centred care, person-centred care. 'Centred' was alternated with 'centered', 'oriented' and 'focused'. The result was 769 hits, the titles of which were all screened to see whether the article related to measure- 
ment instruments. This approach did not result in finding a relevant measure for our purpose.

As well as the Pubmed database, the Cochrane Library was searched for reviews, and experts known to be active in the field of client-centred practice were approached and asked for possible references. Finally, inetrnet websites were searched to find non-published developments in this area. These additional search strategies identified the instrument CCPE (Client-Centred Process Evaluation), developed by Restall, et al (2003). This instrument consists of five parts, including an evaluation of the professional's performance by clients. Since it was designed as a tool for professionals, it was not suitable for the purpose of this study. Lewin et al. (2001) published an interesting review of intervention studies aimed at promoting client-centred care. They also looked at the use of outcome measures in these studies. Seventeen intervention studies were described, none of which used measurement instruments particularly designed to measure clientcentredness from the client's perspective. According to Lewin et al., there is currently no gold standard measure for client-centredness. They state that a widely accepted definition of client-centred care needs to be developed, and recommend further research to develop and test valid, reliable and appropriate tools to assess the effects of interventions aimed at improving and implementing client-centred care.

The results of this literature search lead to the conclusion that there is a lack of feasible instruments measuring client-centredness from a client perspective.

\section{CONCEPTUAL BACKGROUND}

Underlying the development lay a qualitative study of client perspectives on home care. The aim of the study was to analyse how clients who receive home care over a long period thought about client-centredness and what competencies they thought professionals should have to deliver care in a client-centred way. In addition, interaction patterns between client and professional were studied, and facilitating and constraining factors influencing client-centredness were identified (Schoot et al. 2005a, 2005b). Two essential expectations of clients related to client-centredness were identified. Clients experience care as client-centred when they feel recognized and respected by nurses and when they experience autonomy with respect to the way in which care is delivered. These two expectations formed the basis of the questionnaire described in the present article. Items were formulated in accordance with these expectations. In the second phase of their study, Schoot et al. (2005a) identified five central values underlying the above-mentioned client expectations regarding their demand: autonomy (having the possibility to be who you are and self-determination), continuity of life (the desire for flexible care in order to continue one's life), uniqueness (under- 
standing the client as an individual human being with individual demands and wishes), comprehensiveness (the desire to be seen as an integral human being), and fairness (equal distribution of care, according to needs). Three values were identified underlying the care relationship with the caregiver: equality (experience based knowledge is just as valuable as professional knowledge), partnership (accountable, committed and active partners in care), and interdependence (mutual respect, trust and acceptance). Furthermore, it was found that clients differed in their opinions on client-centred care. Individual clients had different expectations and needs, and not all clients felt capable of, or want to be involved in decision-making (Schoot et al 2005b). Items in the questionnaire were intended to cover both the values and individual differences. The value fairness is not represented in the questionnaire because it goes beyond the primary process of care.

Although different aspects of client-centredness were identified, the questionnaire was expected to be unidimensional, i.e. the different aspects could be distinguished, but not separated.

\section{THE STUDY}

\section{Aim}

The aim of the study was to developand test the Client-Centred Questionnaire (CCCQ) to evaluate the client-centredness of professional home nursing care from a client perspective.

\section{Questionnaire development}

The questionnaire should be short and very easy in use, for people with different educational levels. Prior to item formulation the client expectations were discussed and reviewed by the advisory board and the steering committee that were formed for this study. These consisted of experts and clients from different organizations and representatives of national umbrella organizations of nurses, home care organizations and client associations. Full consensus on the client expectations was reached within the advisory board and steering committee. Next, fifteen items were formulated by the research team, in line with the client expectations and underlying values described above. The items were all generated from quotations from client interviews in the study by Schoot et al (2005a, $2005 b)$ that provided the conceptual background for the questionnaire. Each item refered to several of the values and expectations identified. Most items represented an aspect of the care demand as well as an aspect of the care relationship. An example was the item 'I can tell that the carers take my personal wishes into account'. This item relates to uniqueness as well as to interdependence. 
To ascertain the content validity of the instrument, the items were discussed with experienced nurses and a group of experienced clients and then pilot tested with six clients of different ages, sexes and educational levels. After minor adaptations, of the lay-out and wording, the instrument was tested (see table 1 for description of the items). Each item was scored on a 5-point Likert scale, ranging from 'totally disagree' (1) to 'totally agree' (5).

\section{TESTING}

\section{Sample}

The questionnaire was tested in 2003 and 2004 in clients from three different home care organizations in the south of the Netherlands. Two of these organizations had about 4,500 clients, the third was almost twice as large. In the three organizations, clients were selected by care managers according to the following inclusion criteria: adult clients with a chronic illness who received home care by a nurse, who were legally competent and able to communicate, and who were expected to receive care for at least another six months.

\section{Data collection}

Clients who consented received the questionnaire by regular mail, together with a franked and addressed return envelope that could be sent back to the researchers.

\section{Ethical considerations}

Approval for the study was given by the Medical Ethics Committee of the Institute for Rehabilitation Research in Hoensbroek, the Netherlands. Clients were invited by the care managers to participate in the study. They received written information about the study and were asked for written consent. Participation was confidential and anonymity of data was guaranteed.

\section{Data analysis}

Data were analysed using SPSS-pc version 11 for Windows. Descriptive statistics were used to describe the study population and the item responses. Factor analysis (PCA) and reliability analysis (Cronbach's alpha) were used to analyse the internal consistency of the questionnaire. Mann-Whitney's U-test was used to analyse differences between sexes, marital status and living situation. The Kruskal-Wallis test was used to analyse the overall differences between clients from the three participating home care organizations, followed by the Mann-Whitney U test for pairwise comparisons. A total score was computed by adding the item responses, 
resulting in a score with a theoretical range between 15 and 75. Missing values were replaced by the mean of the responses on the other items by the same respondent, unless there were more than two missing values in the whole questionnaire. Cases with more than two missing values were dropped from the analysis.

For validation purposes, clients were asked to rate their overall satisfaction with the care they received on a 10-point rating scale. The correlation between the sumscore and overall satisfaction was calculated with Pearson's correlation coefficient.

\section{RESULTS}

In total 259 clients were approached. Of these, 107 consented and actually participated in the study (response rate 41\%). Mean age of the respondents was 73.5 years (standard deviation 12.5), 52\% were married, $40 \%$ lived alone and $74 \%$ were female. No data are available about possible selection effects. The respondents were not equally distributed over the participating organizations; in one of the organizations only 7 clients responded.

The scores of the total population on the items and the total score are presented in table 1 . The clients rated most items relatively positively, but there were clear differences between items. Clients tended to give a relatively negative rating about their say in the practical arrangements and organization of care: who is coming, how often and when. They also rated relatively negatively the fact that carers quickly said that something was not possible.

The number of missing values was very small. There were four missing values on item 5 and items 3 and 9 had three missing values, indicating that these items were probably relatively difficult to understand. The other items had no more than one or two missing values. No respondent had more than two missing values.

Construct validity was evaluated by means of principal components analysis. This revealed that all items loaded on one factor (eigenvalue 8.716; explained variance $58 \%$ ). The lowest factor loading was 0.49 , others were all above 0.57 .

The internal consistency of the 15 items is high, indicating high reliability: Cronbach's alpha was 0.94 . Therefore the questionnaire score could be a simple sum of item responses. The mean total score was 59 with a standard deviation of 10.0 (theoretical range 15-75). The median was also 59. The distribution of the total score tended to be skewed, but this was not statistically significant (skewness $-.44)$.

In order to find more indications for the construct validity of the questionnaire, the differences between the results of clients from the three homecare organizations were analysed (validity with known groups), as well as the correlation of the total score with some client characteristics (age, sex, marital status, educational 
Table 1. Items and scores for the study population

\begin{tabular}{|c|c|c|c|}
\hline Item & Mean score & $\mathrm{SD}$ & Range \\
\hline I can tell that the carers take my personal wishes into account & 4.3 & 0.7 & $2-5$ \\
\hline I can tell that the carers really listen to me & 4.3 & 0.7 & $2-5$ \\
\hline I can tell that the carers take into account what I tell them & 4.2 & 0.7 & $2-5$ \\
\hline I get enough opportunity to say what kind of care I need & 4.2 & 0.7 & $2-5$ \\
\hline $\begin{array}{l}\text { I can tell that the carers respect my decision even though I } \\
\text { disagree with them }\end{array}$ & 4.1 & 0.8 & $1-5$ \\
\hline $\begin{array}{l}\text { In my opinion the carers are clear about what care they are } \\
\text { able and allowed to provide }\end{array}$ & 4.1 & 0.8 & $2-5$ \\
\hline $\begin{array}{l}\text { In my opinion the carers are sometimes too quick to say that } \\
\text { something is not possible }\end{array}$ & 3.5 & 1.2 & $1-5$ \\
\hline $\begin{array}{l}\text { I'm given enough opportunity to use my own expertise and } \\
\text { experience with respect to the care I need }\end{array}$ & 4.1 & 0.7 & $2-5$ \\
\hline $\begin{array}{l}\text { I'm given enough opportunity to do what I am capable of } \\
\text { doing myself }\end{array}$ & 4.3 & 0.6 & $1-5$ \\
\hline $\begin{array}{l}\text { I'm given enough opportunity to help decide on the kind of } \\
\text { care I receive }\end{array}$ & 3.9 & 0.9 & $1-5$ \\
\hline $\begin{array}{l}\text { I'm given enough opportunity to help decide on how often I } \\
\text { receive care }\end{array}$ & 3.8 & 1.0 & $1-5$ \\
\hline $\begin{array}{l}\text { I'm given enough opportunity to help decide on how the } \\
\text { care is given }\end{array}$ & 4.0 & 0.9 & $1-5$ \\
\hline I have a say in deciding on when carers come to help me & 3.6 & 1.2 & $1-5$ \\
\hline $\begin{array}{l}\text { In my opinion, I am consulted sufficiently on who provides } \\
\text { the care }\end{array}$ & 3.4 & 1.2 & $1-5$ \\
\hline $\begin{array}{l}\text { I'm given enough opportunity to arrange and organise the } \\
\text { care provided myself }\end{array}$ & 3.2 & 1.2 & $1-5$ \\
\hline Total score (15 items) & 59.0 & 10.0 & $31-75$ \\
\hline
\end{tabular}

level) and with overall satisfaction with the care received by the client. Since the questionnaire was intended to measure characteristics of the organization and the professionals working in it, correlations with client characteristics were not expected. Differences between the three organizations, however, were expected. The correlation with overall satisfaction was expected to be high.

The results showed differences between the clients of the three home care organizations: the mean score was $61.8(\mathrm{SD}=8.3), 65.3(\mathrm{SD}=10.6)$ and $56.2(\mathrm{SD}=11.5)$ for organizations A, B and C respectively. According to the Kruskal-Wallis test, these differences were not statistically significant (Chi-square $=4.69$; degrees of freedom 2, $\mathrm{p}=0.08)$. Only the difference between organizations $\mathrm{B}$ and $\mathrm{C}$ was statistically significant according to Mann-Whitney $U$ test $(p=0.049)$.

There was no statistically significant relationship between total score and client characteristics: the correlation with age was -.01 and with educational level .03; the mean score for men was $58.2(\mathrm{SD}=11.1)$ versus 59.6 for women $(\mathrm{SD}=9.4)$; 
the mean score for married clients was $60.7(\mathrm{SD}=9.3)$ versus $59.6(\mathrm{SD}=12.8)$ for unmarried clients.

The correlation between the total score and overall satisfaction with care was .81 $(\mathrm{p}<0.01)$.

These results are generally consistent with the expectations and thus give some support for the construct validity of the total score.

\section{DISCUSSION}

The purpose of this study was to develop and test a short and feasible questionnaire that could be used to evaluate the client-centredness of home care from a client perspective. The questionnaire covers central client values regarding client-centred care found in a qualitative study into the client perspective on home nursing care. It is simple in use and can be administered by regular home care clients of relatively high age. The results show good internal consistency of the questionnaire, supporting the reliability of the questionnaire. Other aspects of reliability were not evaluated, and so this study is not conclusive with respect to reliability of the questionnaire. For descriptive purposes, however, the present results prove sufficient reliability.

Construct validity was supported by the principal components analysis, which indicated a unidimensional structure of the questionnaire, by the strong correlation with overall satisfaction with care and by the differences found between home care organizations. For firm conclusions regarding validity, however, more research is necessary.

Clients ' responses to the individual items give clear clues for improvement of care from a client perspective. They tended to score relatively negatively about their say in the practical arrangements and organization of care and about the fact that carers quickly say that something is not possible.

To meet individual differences in clients with respect to expectations, needs, capabilities and wishes in decision making, the items in the questionnaire under study were formulated in such a way that clients who tend to let professionals decide on care can also answer the questions; each item asks for a personal opinion, and whether the client experiences that a certain aspect of clientcentredness is given enough attention.

Given the high internal consistency, it might be possible to further shorten the questionnaire. This was not done, since the 15 items were a rather strict operationalization of the results of the qualitative study that was on the basis of the questionnaire. From a feasibility point of view, further shortening of the questionnaire seems unnecessary. Furthermore, the reliability analysis did not show a possible increase of Cronbach's alpha when deleting one or more items. 
When using the questionnaire to measure changes, a potential problem may be the fact that item scores tend to be relatively high (=positive). There tends to be a ceiling effect, which might lead to low responsiveness to changes. Whether this is problematic or not needs to be evaluated in a further study with repeated measurements. The total score of the questionnaire tends to be skewed, but this is not statistically significant.

The concept of client-centred care as operationalised in the CCCQ relates to several nursing conceptual models and theories and hence may be valuable from the perspective of these models and theories. According to McCormack (2004), client-centredness is a principle that is implicit in many models of nursing with a humanistic philosophical underpinning. In addition, the work of Rogers (1961) and his articulation of 'the helping relationship' is seen to transcend all these models. Stevens-Barnum (1998) has identified a shift over time in nursing viewpoint. She distinguishes new paradigm theories from traditional theories. Where the traditional theories place the emphasis on the nursing act mainly in acute care, where it is intended to transform an undesirable client situation into a desirable one (goal), in the new paradigm theories the client (in a more diverse context) retains control. Theories in the new paradigm see the client as the main agent, and the nurse as helper. These newer theories (e.g. Quinn, 1992; Watson, 1988) focus on the client and on the interaction. The agent of change is viewed as the individual patient, but the nurse can be a co-participant in change through the care process. The aspects of client-centred care related to the care relationship in the CCCQ fit with the view of the nurse as a co-participant in the care process, and the CCCQ offers possibilities for nurses to reflect on the care relationship with their clients.

\section{STUDY LIMITATIONS}

There are some limitations of this study that should be taken into account when interpreting the results. First of all, the number of respondents was limited and the response rate was only $41 \%$. Nothing is known about the clients who did not consent to participate, except that they were unequally distributed over the participating organizations. The relatively small number of respondents limits the robustness of the principle components analysis. The number of respondents was seven times the number of items in the analysis, which is considered small but acceptable (Tabachnick and Fidell, 2000). The small number of respondents, and especially the unequal distribution among the three participating home care organizations, also limits the power of the analysis of differences between organizations. These findings must therefore be interpreted with caution. Another limitation is that respondents had a relatively high mean age. Thus, it is unclear 
whether the questionnaire is also suitable for younger clients. It has to be further tested in populations with other characteristics and in other organizations.

\section{CONCLUSION}

The CCCQ is a short and relatively simple tool that can be used to evaluate how clients experience the client-centredness of home nursing care. It seems suitable to evaluate care organizations from a client perspective. It may also be used to evaluate the effects of measures aimed at improving client-centredness of care and services, although the responsiveness of the questionnaire may not be very high, as discussed above. It is a feasible measurement questionnaire that can easily be applied in home care settings. It should be realized, however, that client experiences alone are not sufficient to give a view on how client-centred nurses work. At least equally important is the assessment of actual performance of nurses, and instruments to measure nurse competencies and actual performance are needed for that.

\section{ACKNOWLEDGEMENTS}

We are grateful for the help and support of all colleagues and client representatives in the steering committee who were involved in the different stages of the study, as well as all clients and the care managers who participated in the study.

\section{REFERENCES}

Benner P. (1984) From novice to expert. Excellence and Power in Clinical Nursing Practice. Addison-Wesley Publishing Company, California.

Cahill J. (1998) Patient participation - a review of the literature. Journal of Clinical Nursing, 7, 119-28.

CG-Raad (2002) Kinderen en jongeren met een chronische ziekte en hun ouders; een onderzoek naar knelpunten die kinderen/jongeren met een chronische ziekte en hun ouders ervaren in zorgverlening en maatschappelijke participatie. (Children and youngsters with a chronic disease and their parents; a study into problem they experience in health care and in participation in society). Dutch Council of the Chronically Ill and Disabled (CG-Raad), Utrecht, the Netherlands.

Goudriaan G., Vaalburg A.M. (1998) De vraag als maat (Using demand as a yardstick). The Netherlands patients/consumers' Federation (NP/CF) and the Netherlands Institute for Care and Welfare (NIZW), Utrecht, the Netherlands.

King I. (1981) A theory for nursing. Systems, concepts, process. John Wiley, New York. 
Koene G.B.M.L., Grypdonck M., Rodenbach M., Windey T. (1982) Integrerende verpleegkunde. Wetenschap in praktijk. (Integrating nursing. Science in practice). De Tijdstroom, Lochum, the Netherlands.

Law M., Baptiste S., Mills J. (1995) Client-centred practice: what does it mean and does it make a difference? Canadian Journal of Occupational Therapy, 62, 250-7.

Lewin S.A., Skea Z.C., Entwistle V., Zwarenstein M., Dick J. (2001) Interventions for providers to promote a patient-centred approach in clinical consultations. Cochrane review.

McCormack B. (2004) Person-centredness in gerontological nursing: an overview of the literature. Journal of Clinical Nursing, 13(3a), 31-38.

Patterson J.G., Zderad L.T. (1976) Humanistic nursing. Wiley, New York.

Quinn J.F. (1992) Holding sacred space: The nurse as healing environment. Holistic Nursing Practice, 4, 26-36.

Restall G., Ripat J., Stern M. (2003) A framework of strategies for client-centred practice. Canadian Journal of Occupational Therapy, 70, 103-12.

Rogers C. (1961) On becoming a person. Boston: Houghton Mifflin Co.

Sainio C, Lauri S, Ericksson E. (2001) Cancer patients' views and experiences of participation in care and decision making. Nursing Ethics, 8, 97-113.

Schoot T., Proot I., ter Meulen R., de Witte L. (2005) Recognition of client values as a basis for tailored care: the view of Dutch expert patients and family caregivers. Scandinavian Journal of Caring Sciences 19,169-176.

Schoot T., Proot I., ter Meulen R., de Witte L. (2005) Actual interaction and client-centeredness in home care. Clinical Nursing Research,14, 370-93.

Stevens-Barnum B.S. (1998). Nursing theory: analysis, application, evaluation. New York: Lippincott.

Sumsion T. (2005) Facilitating client-centred practice: insights from clients. Canadian Journal of Occupational Therapy, 72, 13-20.

Tabachnick B.G., Fidell L.S. (2000) Using multivariate statistics (4th ed.). HarperCollins College Publishers, New York.

VWS. (1999) Zicht op Zorg: plan van aanpak modernisering AWBZ (Care within sight: plan to reform the general law on Special Medical Expenses). Ministry of Health, Welfare and Sport (VWS), The Hague, the Netherlands.

Watersworth S., Luker K.A. (1990) Reluctant collaborators: do patients want to be involved in decisions concerning care? Journal of Advanced Nursing, 15, 971-976.

Watson J. (1988) Nursing: human science and human care. A theory of nursing. New Yorik: National League for Nursing.

Witte L.P de, Benjaminsen S., van den Heuvel W. (2003) Participatie van kinderen en jong volwassenen met een functiebeperking. Een analyse van knelpunten t.a.v. participatie en een voorstel voor een landelijk programma van onderzoek, ontwikkeling, informatievoorziening en implementatie. (Participation of children and young adults with a disability. An analysis of problems regarding participation and a proposal for a national programme of research, development, information and implementation). Institute for Rehabilitation Research (iRv), Hoensbroek, the Netherlands,

www.kiesBeter.nl 


\section{DEVELOPMENT OF COMPETENCIES AIMED AT CLIENT-CENTRED CARE: AN EVALUATION STUDY}

Tineke Schoot, Math Hirsch, Luc de Witte

Learning in Health and Social Care. Submitted, revised paper 


\section{ABSTRACT}

The aim of this study was to evaluate a learning programme for Dutch community nurses and auxiliary nurses aimed at the development of competencies with respect to client-centred care for chronically ill clients. The study was guided by the Kessels's Eight-fields model. Several stakeholders, including clients, participated in the development, execution and evaluation of the programme. The concept of client-centred care, client goals and competencies for nurses were identified systematically. Competencies identified were: a care process in dialogue, enabling client participation and dealing with tensions. Principles of development of competencies were applied in the design of learning activities. The programme was evaluated at three levels: learning processes; performance of competencies in practice; and perceived client-centredness by clients. Three home-care organizations were involved in the evaluation study. In total 175 employees participated in the basic module and 34 nurses and auxiliary nurses participated in the advanced module. In total 107 chronically ill clients were involved in the study, of which 50 in the evaluation group and 57 in a group checking for selection bias. Findings indicate a positive impact on two of the evaluation levels: learning processes and the performance of nurse's competencies in practice. No statistically significant impact was found on clients two months after the end of the programme. The process evaluation provided knowledge concerning preconditions for learning processes and performance of competencies in practice. The study concludes that it seems that a change towards clientcentred care has been initiated. Client-centred care encompasses more, however, than competence development in individual nurses. A corporate approach is recommended, encompassing the support of the primary process of clientcentred care by the entire care organization. Further research aimed at the implementation of client-centred care is recommended.

Keywords: client-centred care, development of competencies, nurses, process evaluation, self-assessment, assessment 


\section{INTRODUCTION}

Client-centred care is defined as care that optimally fits the needs and demands of individual clients. This approach to care has gained increasing emphasis in the delivery of care in most Western countries (Latvala, 2002; Lewin, et al., 2001; Saunders, 1995). Concepts closely related to client-centred care are client autonomy, client participation and shared decision making (Agich, 2003; Cahill, 1998; Elwyn, 2001). The Dutch government stimulates care organizations to take their clients' wishes and demands as the starting point for care. On the face of it, applying client-centred care in practice seems simple. However, it appears to be a complex and contested concept (Cahill, 1998; Rijckmans et al., 2002; van der Kraan, 2001). Client-centred care implies changes not only in the role of the client, but also in the role and competencies of the professional.

Studies evaluating interventions aimed at promoting client-centred home care by nurses are scarce. Lewin et al.'s (2001) systematic review of studies evaluating interventions intended to promote client-centred care in clinical settings revealed fairly strong evidence that some interventions may lead to increases in the clientcentredness of consultation processes. There is also some evidence that training health care providers in client-centred approaches may impact positively on client satisfaction with care. Although the studies displayed considerable heterogeneity in terms of the interventions and the outcomes assessed, all used training of professionals as an element. However, this review included only two studies with nurses (Kinmonth et al., 1996; Pill et al., 1998).

In this article we report on the development and evaluation of a learning programme aimed at improving the competencies nurses need for providing client-centred care. Hence the central question in the present study is: Can the competencies needed for client-centred care be influenced and developed by a learning programme?

Three home care organizations, delivering care to clients in their personal homes, were involved. In this study we use the term 'client' rather than 'patient'; and the term nurse includes auxiliary nurses unless otherwise stated.

\section{MODEL FOR DEVELOPMENT AND EVALUATION OF EDUCATION PROCESSES}

As theoretical basis for developing and evaluating the programme, we used Kessels's Eight-fields model (see figure 1 below). This model offers an empirically tested conceptual framework to design and evaluate learning programmes in practice (Kessels \& Plomp, 1999; Kessels, 1993; Kessles. 1996). The fields in the model guided the development of the desired situation (in this study from intended client outcomes to nurse competencies and thence to learning situa- 
tions) and the evaluation of the outcomes achieved at different levels (learning processes, competencies in practice and perceived client-centredness) in close collaboration with central stakeholders. The learning situations (planned learning activities and learning processes) were intended to enable employees to acquire skills, knowledge and attitudes that influence their performance of competencies in practice, so that it has an impact on clients.

A 'competency' is defined as the ability to use a set of knowledge, attitudes and skills, in order to perform concrete activities in an adequate way, and in the same time deal with tensions (tasks, problems, dilemmas and contradictions) encountered in the practice situation (Onstenk, 1997). Professional competency implies integration of knowing, skills and attitudes in practice (Leung, 2002; van leeuwen, 2005). In discussions about professional competency, ethical and attitudinal elements in the client encounter are central (Veloski et al., 2005).

Development Evaluation

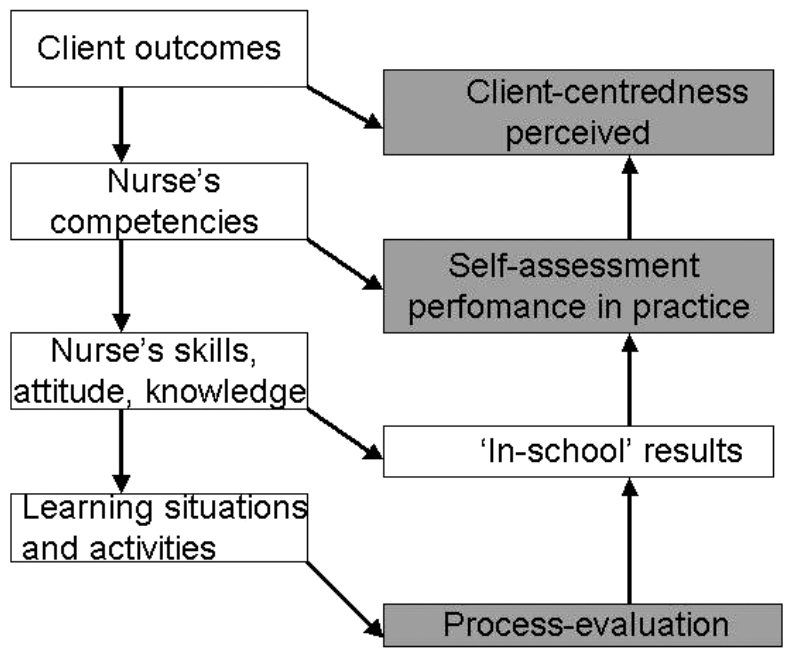

Figure 1. Kessels's Eight-fields model

NB The shaded fields refer to the fields that were evaluated

\section{PROGRAMME DEVELOPMENT}

The rationale for the programme came from previous qualitative research conducted by the authors to explore the client's views on client-centred care, client-centred competencies of nurses and tensions experienced by nurses (Schoot et al., 2005a; Schoot et al., 2005b; Schoot et al., 2006). 
A programme development group, a steering committee and an advisory group were involved in the development of the programme. The programme development group consisted of six experts with knowledge of the central theme: representing a centre for secondary professional education, the Dutch Council of the Chronically Ill and the Disabled (CG-Raad), the Institute for Rehabilitation Research (iRv), and two universities for professional education. The steering committee consisted of nurses and managers of the care organizations involved, members of the client council of three home care organizations involved and members of two provincial patient organizations. The advisory group consisted of several national umbrella organizations for clients, nurses and nurses' assistants.

Working definitions of client-centred care, client outcomes and competencies (Schoot et al., 2004) were developed by the programme development group in collaboration with the steering committee. Full consensus was achieved. All steps were validated by the advisory group.

Client-centred care was defined as:

Care that arises from the individual preferences and demands of the client, that is accomplished in a dialogue, and in which the client has the final say.

Client outcomes were defined as:

The client expresses feelings of being respected and taken seriously by the professional.

The client expresses feelings of autonomy in the way care decisions are made.

Three competencies for nurses with respect to client-centred care were defined:

Care process in dialogue:

In dialogue with the patient, the caregiver discusses the care process from the perspective of the patient and on the basis of his or her professional expertise.

Enabling client participation:

The caregiver assists the patient in formulating his or her questions and wishes with respect to entire care provision and encourages the patient to take control of the care process.

Dealing with tensions:

The caregiver is able to deal with any problems and contentious issues that may arise. The caregiver actively seeks out alternative options in the event of tensions between the client perspective and professional, individual and organisational responsibilities. 
A social constructivist perspective and principles of competency-based education were integrated in the learning activities chosen, such as the emphasis on the nurse's experiences in everyday practice, reflection, self- assessment, transfer and implementation in practice. Learning prevailed over educating. Consequently, participants should be encouraged to direct their own learning needs based upon insight into their own competencies (Bolhuis, 2001; Colardyn, 2002; Dochy et al., 2002; Eraut, 1994; Onstenk, 1997; Schön, 1987).

\section{DESCRIPTION OF THE PROGRAMME}

The entire learning programme is called 'Care in Dialogue'. Discussion between the programme development group and the steering group led to a two-module design, a short (2 half-days) basic module for all employees and an advanced module (7 half-days) for some of the nurses and auxiliary nurses who had attended the basic module. The programme was offered during working hours; and the time interval between all sessions was about two weeks. Each care organization had its own schedule.

Table 1 shows the overall design of the basic and advanced modules. The underlying skills, knowledge and attitudes, which the intervention seeks to develop in each session, are listed for both modules; and the learning activities are also specified. The role plays and practice situations discussed in these activities were partly based upon the previous research studies mentioned above, and partly provided by the participating nurses during the programme. Competencies were only specified for the advanced module. In order to achieve lasting impact, attention was paid to giving feedback to colleagues, implementation of structured critical reflection, and follow-up sessions. The programme included a tutorial guide, encompassing the aims of each session, information about the learning activities and evaluation forms.

Three nurse academics were involved as tutors, two of whom were members of the programme development group. Six expert clients and expert family caregivers were recruited from the Dutch Council for the Chronically Ill and the Disabled (CG-Raad) to be additional tutors for several sessions. They played an important role in moral development by expressing the client perspective, participation in role plays, participation in discussions and giving feedback to the participants. All experts received some preparatory training, mainly focussed on giving feedback and participating in the role plays.

The basic module was designed for 25-40 persons per meeting and focussed on orienting all employees to the wishes and demands of clients and the tensions 


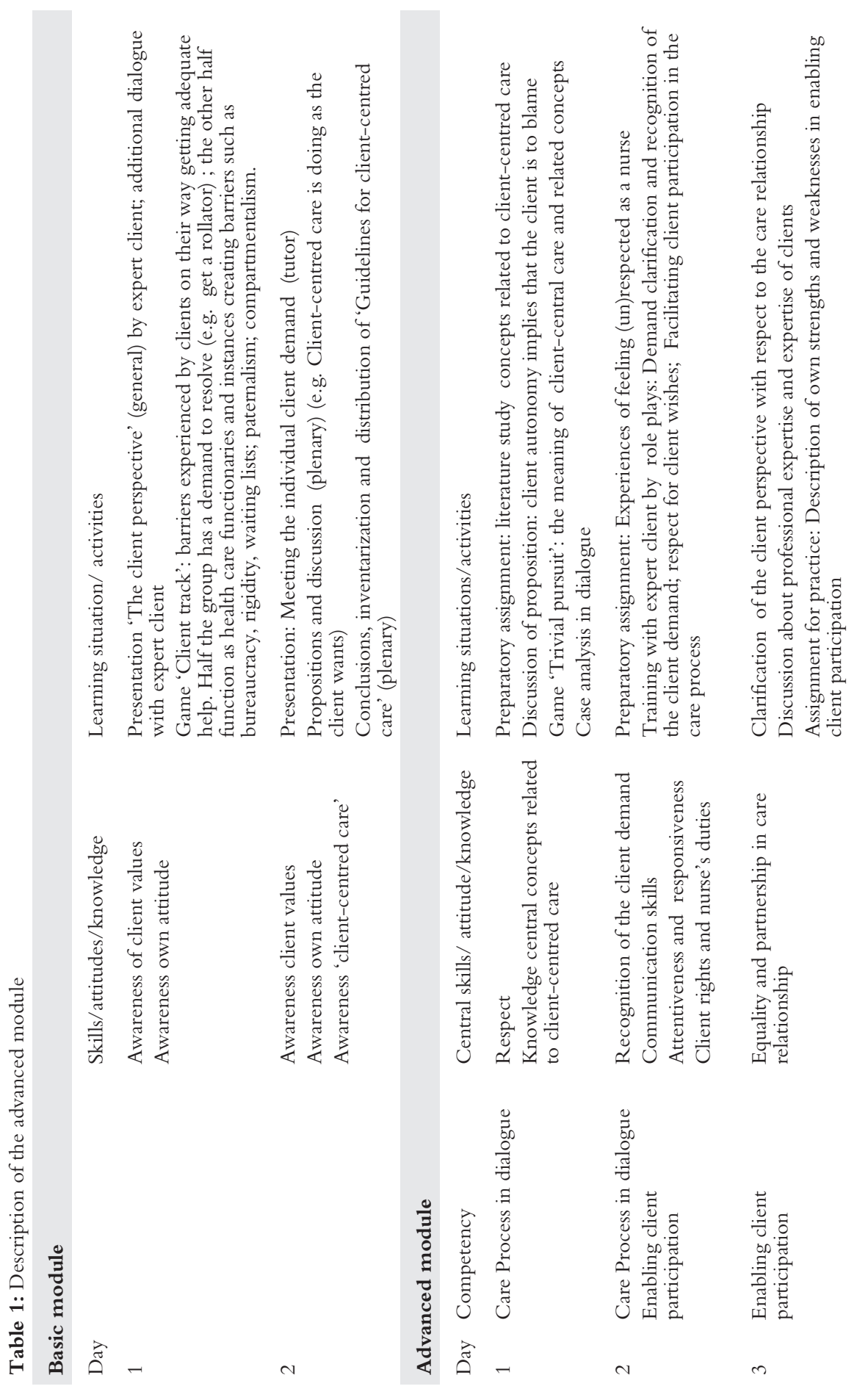


152 CHAPTER 8
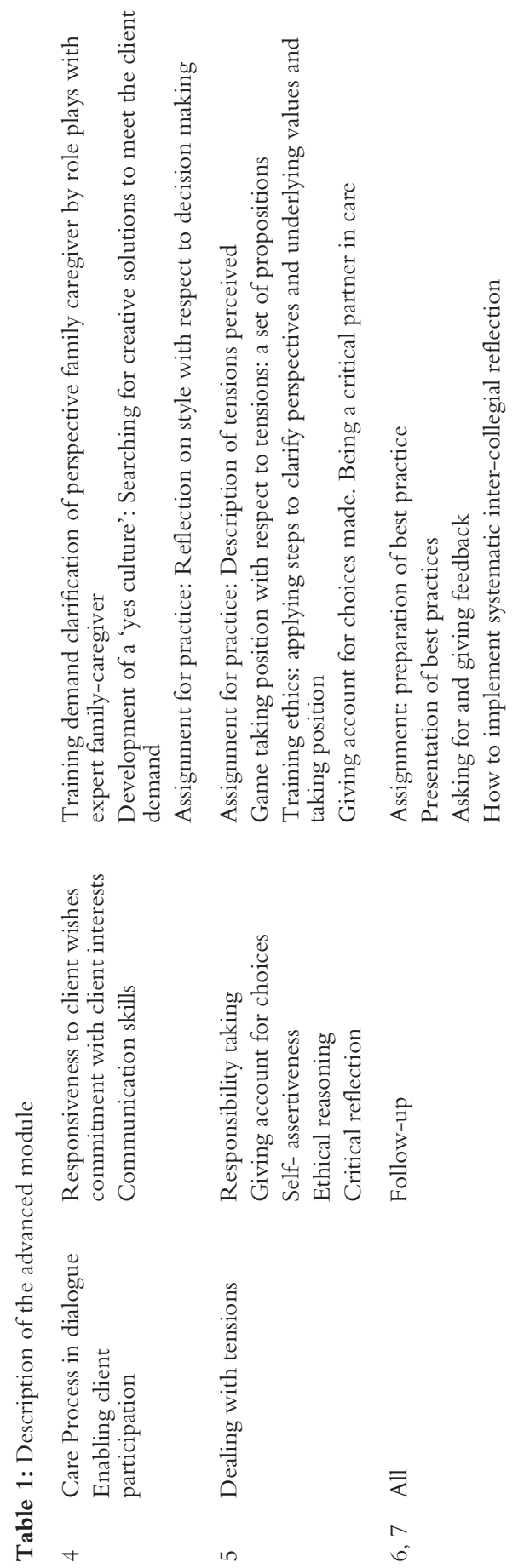
likely to arise in particular situations. The advanced module was designed for smaller groups of 10-12 nurses and auxiliary nurses working in primary care.

The planning of the learning programme was coordinated by one of the members of the development group, together with a contact manager in each care organization. The planning was made before it was known exactly how many people were coming. In each care organization, two groups were planned to attend the basic module and one group to attend the advanced module.

Four inter-collegial tutor meetings were held during the programme, attended by the tutors, a representative of the expert clients and the researcher. One of the tutors chaired ran these meetings, which focussed on the evaluation and preparation of the sessions.

\section{DESIGN OF THE EVALUATION}

The research questions for the evaluation study were:

1. Did the learning processes proceed as intended and which factors influenced the learning processes?

2. How do nurses assess their competencies with respect to client-centred care before and after the education programme, and which factors influenced performance in practice?

3. How do clients perceive the client-centredness of the care provided by their home-care nurses before and after the learning programme?

The study included an evaluation at three levels: 1) a process evaluation of the learning activities during the programme; 2) self-assessment of their competencies with respect to client-centred care by the participating nurses; 3) assessment of the client-centredness of the care provided by the visiting home care nurses by some of their clients. We included the process evaluation, because it helps to identify factors that affect the impact of the sessions, and which might be changed to improve the programme and its implementation in the future (Brug et al., 2000).

Competencies were self-assessed before the start of the basic module and at the end of the advanced module. The perceived client-centredness of care was assessed by clients before the start of the basic module and two months after the end of the advanced module. Only the primary responsible nurse of each client involved followed the programme. The primary responsible nurse is responsible for the care plan and in general provides a substantial part of the day-care for the 
client during the week. Apart from their primary responsible nurse, all clients receive care from other nurses, especially clients who need care seven days a week, more than once a day. The perceived client-centredness assessed concerned care performed in general by all the visiting home care nurses.

In order to check whether the experiences of the clients selected for the evaluation study were typical of clients receiving homecare, we included a second group of clients from one care organization, whose primary responsible nurse did not attend the programme, in the distribution of the pre-training questionnaire.

The study was carried out within three home-care organizations in different cities in the south of the Netherlands in 2003-2004. Ethical approval was given by the Ethics Committee of the Institute for Rehabilitation Research at Hoensbroek.

\section{DATA COLLECTION AND INSTRUMENTS}

\section{Process evaluation}

Methods used in the process evaluation were partly qualitative and partly quantitative. Activities and reactions with respect to the basic and advanced module were documented by session reports written by the tutors, guided by semi-structured points of attention (e.g. group functioning; reactions with respect to central themes and learning situations chosen), and a pre-structured programme evaluation, questioning all elements of the programme such as aims, themes, organization, tutors, tools and contribution of the participants. Answers were given on a 5-point Likert scale, ranging from 'totally disagree' (1) to 'totally agree' (5). Participants were also asked about their satisfaction with the basic and advanced module on a 10-point rating scale. Two open questions concerning elements of appreciation and of improvement were added.

\section{Self-assessment of nurse competencies}

The 'Care in dialogue Competency Scale, a self-assessment scale for nurses was developed for this study (Schoot et al., 2004). The scale is an operationalization of the three competencies mentioned earlier: Dialogue (18 behavioural statements), Enabling client participation (10 behavioural statements) and Dealing with tensions ( 8 behavioural statements). For each of the statements nurses were asked to indicate the extent to which the behaviours described applied to them when working in practice with clients. Scores were on a four-point Likert scale: $1=$ not really; 2 = to a limited extent; 3 = regularly; $4=$ often. Nurses were encouraged to ask for feedback from their clients and colleagues with respect to the items in the 
self-assessment scale. The scales were tested for internal consistency using Cronbach's alpha, yielding .81 for 'care in dialogue'; 72 for 'enabling participation'; and .74 for 'dealing with tensions'.

\section{Perceived client-centredness}

A questionnaire was developed to assess client-centredness perceived by clients: the CCCQ (Schoot et al., 2004). This instrument is an operationalization of the client outcomes mentioned earlier. It consists of 15 statements about the clientcentredness of care. Clients were asked to indicate the extent to which they agreed in general with each statement on a five-point Likert scale: $1=$ strongly disagree; 2 =disagree; $3=$ don't know/no opinion ; $4=$ agree; $5=$ strongly agree. The total score theoretically ranges from 15 (strongly disagree) to 75 (strongly agree). The reliability of the questionnaire was high (Cronbach's alpha $=.94$ ).

\section{RESEARCH SAMPLE}

In each care organization two groups attended the basic module and one group the advanced module, as planned. In total, 175 employees participated in the basic module. Participants varied from auxiliary nurses to the managing director of the organization. Each group consisted of 16-40 participants. About $80 \%$ of the participants were nurses and auxiliary nurses.

In total thirty-four nurses and auxiliary nurses participated in the advanced module. This was only a small part of the total group of nurses in the respective care organizations. The selection criteria for nurses were 'being a primary responsible nurse of chronically ill clients', and 'having followed the basic module'. Before the start of the basic module, the nurses attending the advanced module had agreed to attend both modules. The selection took place based on spontaneous application and an active approach by the manager. There was no pressure to participate. In order to improve active implementation in practice, some managers preferred to select highly educated nurses who were very motivated, who worked almost full-time for the organization and whowere natural leaders within the team. Two of the three organizations preferred to select one participant per team, while the other preferred two participants per team. The rationale for participation of only 1-2 nurses per team was an expected transfer and implementation by the trained nurses within the teams. The background variables of the participating nurses with respect to the different care organizations are shown in table 2. Only one male nurse participated. 
Table 2. Background variables of the nurses following the advanced module

\section{Organization}

Number of nurses

Age

$$
\begin{aligned}
& 20-30 \text { years } \\
& 31-40 \text { years } \\
& 41-50 \text { years } \\
& 50+\text { years }
\end{aligned}
$$

Years in organization

$$
\begin{aligned}
& <1 \text { year } \\
& 1-3 \text { years } \\
& >3 \text { years }
\end{aligned}
$$

Education level

$$
\text { auxiliary nurse }
$$

registred (community) nurse unknown
A

12

13

$$
2
$$

3

6
1

1

1

1

11
C

9

3

2

1

2

3

4

211

$10 \quad 11$

$\begin{array}{lll}- & 1 & 2\end{array}$

Working hours a week

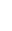
4 2
3

3

6

$<20$

$30+$ hours/week 5

$3 \quad 3$

$5 \quad 6$

Table 3. Background variables of the clients of the evaluation group $(\mathrm{N}=50)$

\section{Characteristics}

$\mathbf{N}$

Age

$<40$ years $\quad 3$

$40-60$ years $\quad 10$

$60+\quad 37$

Male

Education

No education / only primary school

Higher vocational education/university

Having a personal budget

Living alone

Duration home care

$$
\begin{aligned}
& <0.5 \text { year } \\
& 0.5-1 \text { year } \\
& >1 \text { year }
\end{aligned}
$$


The selection criteria for clients to participate in the evaluation were: having a chronic illness (of a somatic nature), being competent and capable of communicating and expected to receive care for the coming six months. Clients meeting the criteria were invited to participate in the study by a by letter from the relevant care manager. They received information about the study and were asked for written consent. Participation was confidential and anonymity of data was guaranteed. Clients who consented received the questionnaire by regular mail, together with a franked and addressed return envelope that could be sent back to the researchers. The average number of clients invited per participating nurse was four. The total number of clients approached for the evaluation group was 155 . Fifty of these clients gave informed consent (32\%). The characteristics of the clients of the evaluation group are shown in table 3. The client group assessed to check for selection bias (comparison group) comprised 57 clients (response 65\%). The evaluation group and the comparison group were comparable with respect to the background variables, except for the duration of care: $64 \%$ of the clients participating in the evaluation study had received care for more than 1 year, compared to $84 \%$ of the clients in the group controlling for selection bias.

\section{DATA ANALYSIS}

Qualitative data obtained with the process evaluation were categorized as facilitating and constraining factors. The results of the pre-structured programme evaluation were analysed with descriptive statistics.

For data obtained by the competency scale, and by the client instrument, the individual total scores of each nurse and client were calculated before and after the intervention. We used Wilcoxon Signed Ranks Test for paired samples to identify changes in the mean scores for all three competencies in nurses, and for perceived client-centredness in clients. Missing values were replaced by the mean of the responses on the other items by the same respondent, unless there was more than one missing value. Cases with two ore more missing values were removed from the analysis. We used non-parametric correlation (Kendall's tau) to calculate the correlation of the total scores with background variables.

Data were analysed on an 'intention to treat' basis. This means that all clients selected for the evaluation group were assessed both times, whether their nurse responsible finished the programme or not. 


\section{RESULTS}

\section{Process evaluation}

With respect to the basic module, tutors reported that in general the participants were motivated and participated in all elements. Some participants experienced presence of the management as very stimulating: 'they really take it seriously!' However, some participants experienced them as too dominant in the discussion. It was striking that several participants were convinced that 'we already work client-centred'. The tutors mentioned an advantage of a plenary discussion was that implicit values conflicting with client-centred care(e.g. uniformity of care, efficiency) could be identified by the tutor. On the other hand, discussions with a heterogeneous group consisting of 40 persons were experienced as difficult. Discussions revealed several barriers experienced in performing client-centred care, such as the need for production and bureaucracy. In general, there was a need for concrete instructions with respect to client-centred care: "what should we do?". The open questions at the end of the programme made clear that the contribution of the client experts and the discussions within the group were appreciated most, and contributed to awareness of wishes and demands of clients and awareness of difficulties and barriers for client-centred care in the actual situation.

The mean satisfaction report mark for the basic module was 7.4. All items of the pre-structured programme evaluation scored higher than 3.5. Only one item (difficulty of the programme) scored below 3 (2.85).

The advanced module was given a report mark of 8.2. Almost all elements in the pre-structured evaluation of the advanced module questioned had a mean score greater than 3.5. The elements appreciated very much by the participants (mean score $>4$ ) were: the feedback of expert clients, the variety of the programme, the assignments aimed at application in practice, the organization of the programme, the productivity of the sessions. The lowest mean score was the difficulty of the programme (score 3). Additional information in the open questions about elements appreciated very much, mentioned by more than four participants, were: the support of the group, the reality of the practice situations chosen, active learning activities, the presentation and discussion of best practices during the follow-up sessions. Additional information about elements disliked, mentioned by more than four participants, were: not enough time to learn at work and 'having to squeeze' learning activities in between work; lack of understanding with colleagues not attending the programme and with the manager. Finally, some auxiliary nurses found some elements of the programme were too complex. 
The tutor reports supported the findings of the pre-structured programme evaluation. The themes and didactic principles chosen encouraged the participants to participate actively in their learning process and to actively perform competencies in practice. Both tutor reports and the open questions showed illustrations of a development of the participants towards an attitude of increased clientcentredness. Examples of this are:

"In fact, everything we do should be on behalf of the client. Far too many things we do are on our own behalf or on behalf of the organization".

"We decide too much for the client. We should learn to respect client autonomy".

"I have to get rid of the automatism. I am working hard at it".

"We should get more to the roots of the client demand. Now, we think we know what the client wants. But too often you don't".

Soon after the beginning of the programme, four nurses in one group dropped out of the programme. Reasons given were too heavy a work-load, forcing them to set other priorities $(3 \mathrm{x})$, and long-term illness $(1 \mathrm{x})$. The remaining participants of this group, predominantly auxiliary nurses, all felt that they had to squeeze the training in between their work. Several skills required, such as self-assertiveness, reflection on action, skills to regulate the conversation, and a critical attitude, appeared to be underdeveloped. Most of them perceived these elements as too complex.

In total six participants missed one or two sessions. The participants stated that the nurse competency scale contributed to awareness of their behaviour, and to critical reflection on care and their care relationship with the client. Both participants and tutors reported that participants had over-estimated their competencies at the assessment before the start. Some remarks of participants after the programme were:

"I thought I already behaved in a client-centred way, but only now I really do."

"You think you do well, but too frequently, this feeling is only based upon your own experience. You don't really know how the client feels about it."

"We are good at doing things the client does not ask for."

Participants reported several barriers related to performance of the competencies in practice, such as the central organization of work processes (central planning; 
task-oriented organization of work), a heavy workload, lack of support from colleagues, and lack of support by their manager. Several remarks refer to another constraining factor of the programme: the challenge to reach employees who are not aware of the need to change their behaviour.

One nurse illustrated this very well:

"You will not find here the colleagues who really need development of competencies with respect to client-centred care'.

\section{Self-assessment of nurse competencies}

All participating nurses on the advanced module (34) completed the preprogramme assessment, 28 completed the post-programme assessment. Besides four drop outs, two nurses could not fill in the final assessment due to other priorities. Table 4 presents the mean scores of the nurses before and after the programme. Participants with two or more missing values were removed from the analysis. This explains the lower number of participants indicated. There is a significant change for all three competencies.

There is no correlation of the competencies with background variables, except for a significant positive correlation of the test score after the programme of the competency 'care process in dialogue' with age (correlation coefficient .31).

Table 4. Mean score nurse competencies before and after the programme

$\begin{array}{llll} & \text { Before } & \text { After } & \text { N } \\ \text { Competency 'care in dialogue' (SD) } & 56.4(6.0) & 59.2 \star(5.6) & 24 \\ \text { Competency 'enabling participation' (SD) } & 30.4(3.3) & 32.7 \star(3.1) & 26 \\ \text { Competency 'dealing with tensions' (SD) } & 25.5(3.2) & 27.7 \star(3.4) & 21 \\ \star P \leq 0.05 & & & \\ S D=\text { Standard deviation } & & \end{array}$

\section{Perceived client-centredness}

Fifty clients (32\%) gave written informed consent and responded to the preassessment. Thirty-six of these clients responded to the post-assessment. The reasons for dropping out during the study were admission to a nursing home, termination of care, or death.

The mean total scores and the mean general satisfaction scores of the 36 clients who completed both assessments are shown in table 5 . There is no significant change. There was no correlation of the scores with the background variables before and after the intervention. 
Table 5. Perceived client-centredness by clients who completed both assessments and by clients of the comparison group

$\begin{array}{llll}\begin{array}{l}\text { Evaluation group both } \\ \text { assessments (N=36) }\end{array} & \text { Before } & \text { After } & \begin{array}{l}\text { Comparison group } \\ \text { (N=57) }\end{array} \\ \begin{array}{l}\text { Sumscore } \\ \text { Mean (SD) }\end{array} & 59.9(9.5) & 61.4(6.7) & 59.0(10) \\ \text { Range } & 37-75 & 48-72 & 33-75 \\ \text { General satisfaction } & & & 8.1(1.3) \\ \text { Mean (SD) } & 8.3(1.6) & 8.4(1.2) & \\ \text { SD=Standard deviation } & & & \end{array}$

The mean total score of the group checking for selection bias was 59.0, which is not significantly different from the evaluation group. The mean general satisfaction with nursing care of this group was 8.1 , which is also not significantly different from the evaluation group.

\section{DISCUSSION AND CONCLUSIONS}

The central question was if competencies needed for a client-centred approach can be influenced and developed. In order to answer this question, an evaluation study was performed at three levels, guided by Kessels's Eight-fields model. In this section we will discuss the findings.

\section{The framework used}

Kessels's Eight-fields model provided a valuable and flexible structure to organize and align discussions and activities of the stakeholders involved. The strengths of the present study are the multiple evaluation at three levels, evaluating the perspectives of both clients and nurses with different methods and instruments. Internal and external validity was achieved by the systematic method applied in collaboration central stakeholders (Kessels 2004).

A constraining factor was the gap between requirements with respect to scientific research on the one hand and reality of practice (e.g. pressure of time, and restrictions by the care organizations) on the other (Kessels 2004). A limitation of the programme as developed and executed was the restriction of the implementation of client-centred care to the development of competencies in a few nurses. Although attempts were made to influence colleagues and managers via the participants of the programme, the process evaluation indicates that a corporate approach, encompassing the entire care organization, would probably have been more effective. 


\section{Process evaluation}

The process evaluation was based upon triangulation of methods (Denzin \&Lincoln 2003). Both qualitative and quantitative data were collected.

Factors that constrained the learning processes are: lack of time needed and a lower education level. Factors that constrained performance in practice are: central planning, task-oriented system, too heavy a workload, lack of support from colleagues and management. Lack of time needed seemed to contribute to attrition. The attrition with the nurses can be seen as an illustration of the tension between client-centred care and other demands, such as production. Facilitating factors for learning processes and application in practice were: the feedback of the expert clients, the dialogue within the training group, support by an implementation committee established within the care organization for this purpose, sufficient time, support of colleagues and manager, and structural critical reflection. Verkerk, de Bree \& Jaspers (2004) stress the importance of structural critical reflection and accounting for care given in a certain context of care. The facilitating and constraining factors found in the process evaluation offered insight into learning needs, learning conditions and conditions for implementation in practice. A characteristic of nurses and auxiliary nurses visiting personal homes is that they conduct their visits on their own. Practitioners only rarely see each other at work, so the chances of those participating in the programme to pass on their changed perspectives would be slim, unless their organization arranged some special 'transfer' sessions.

It is questionable if the notion of one personal nurse, providing the majority of the care, is a delusion. Apart from their primary responsible nurse, clients receive care from several other nurses. Partly, discontinuity of carer is unavoidable, due to the extent of the client demand, particularly in clients who need care each day, several times a day. Furthermore, it seems to be a systemic problem as well as a problem of competency of individual carers.

The process evaluation stresses that implementation of client-centred care through the development of competencies in nurses should not be isolated from policy, structures and processes at other levels of the care organization. Support of client-centred care in the primary process needs to be embedded in the attitude, policy, structure and processes of all persons and at all levels of the care organization. These findings are consistent with the literature, stating that the entire organization should learn in order to improve their performance (Argyris, 1991; Senge, 1992). 
A critical question concerns the challenge to reach employees who are not aware of the need to change their behaviour (Coulehan \& Williams, 2003). These employees are not ready to learn because they do not experience their attitude as a problem. These employees take either a covert, defensive attitude, or act as victims, not able to find a solution (van Eekelen, 2005).

The number of participants in the basic module and the heterogeneity of the group compromized the guidance of the discussion and the participation of less assertive participants. An option is to make a smaller, less heterogeneous group (only the nurses and their managers). This would be disadvantageous, however, from the point of view of the multidisiplinary approach of client-centred care. Another option is to break into sub-groups. A disadvantage of this measure could be that tacit commitment to behaviours grounded in an ethic of detachment, selfinterest and objectivity remains unidentified (Coulehan \& Williams, 2003).

A critical question concerns the development of a standard programme beforehand versus learning on demand by participants. Although the programme paid attention to individual differences, it did identify substantial differences with respect to learning needs.

\section{Evaluation of competencies}

Developing competencies needed for client-centred care emerged as a process of professional socialization. The social constructivist perspective chosen in the present study offered nurses opportunities to identify with values underlying client-centred care in the context of nursing care (Clouder, 2003). A critical question concerns 'true conformity' and a lasting impact of the learning programme developed. Despite some measures taken to improve transfer and implementation, additional follow-up sessions to reinforce the processes intended are recommended. A critical question concerns selection bias in nurses because some nurses with certain characteristics were invited by their managers to participate. Further research in nurses with other characteristics is recommended.

Communicative, regulative, reflective skills and self-assertiveness seemed to be underdeveloped mainly in auxiliary nurses. Therefore it is recommended that there should not be more than one third of auxiliary nurses in a group. The development of a separate programme meeting the learning needs of auxiliary nurses might be considered.

Nurse's competencies were assessed by self-reports (Tillema, 1997). In order to prevent measurement errors (e.g. situational bias, and social desirability), the 
assessments with the competency scale were anonymized and incorporated into the education programme (Polit \& Humgler, 1995). In this way, the participants were less aware of the evaluation study and were more likely to reflect reality. Despite these measures, the test score before the programme may have been influenced by social desirability. This is confirmed by the process evaluation. The participants estimated themselves more client-centred before the programme than they were in reality. Several participants said that they thought they already worked in a client-centred way and that they only later, during the programme, understood the real meaning of client-centred care.

\section{Client evaluation}

It appeared to be difficult to quantify the impact of training professionals in clientcentred care on clients. An experimental design with participants randomly assigned to the evaluation group and a control group is not appropriate for two main reasons: the institutions have strategic interests in training specific nurses, and the programme was designed to have an impact on all professionals and their clients of the organization. The results of the present study should be viewed with caution in the absence of a control group. The group checking for selection bias should not be compared to a control group, as it only aimed at identification of possible selection bias in clients before the programme.

Although we could not identify a significant statitstical impact on the mean scores of client-centredness two months after the end of the programme, we do not think that the programme needs improvement, because an impact has been signalled at two of the three evaluation levels. A plausible explanation for not finding an impact on clients seems to lie in the fact that only a few nurses were trained, while the clients assessed in general receive care from several nurses, especially clients who need care seven days a week, more than once a day. Another possible explanation might be the high test scores before the programme. Furthermore, the duration of the study may have been too short to detect a change. The planning of the test two months after the end of the course may have been too soon to give the nurses the opportunity to apply the developed competencies in practice. Finally, explanation may lie in the organizational barriers experienced by nurses that could not be removed by their own individual actions.

The response from clients was very low. The distribution of clients over the distinct organizations varied. We do not think this is a problem, because we wanted to consider the total group. Client attrition could be attributed in most cases to natural events such as death or hospital admission. Therefore we do not 
think this influenced the results. Besides follow up of the training, repetitive measurement with additional semi-structured interviews are recommended.

\section{Conclusions and implications}

It seems that the competencies required for client-centred care in nurses can be developed. This study offers several indications that the programme 'care in dialogue' initiated a positive impact on two of the evaluation levels: the learning process and the performance of competencies in practice. Although we could not identify a statistically significant impact on client-centredness experienced by clients two months after the end of the programme, we think a change towards client-centred care has been initiated. This study makes it clear that development of competencies in nurses is not sufficient in effectuating client-centred care. Client-centred care needs to be embedded in the attitude, policy, structures and processes at all levels of the care organization. Based upon the findings of the process evaluation, it is expected that the impact of the programme on clients will become more visible if more nurses were to attend the programme and if a corporate approach was used to develop support of the primary process by the entire care organization.

A learning programme is available for nurses and auxiliary nurses that seems to have a positive impact on competencies with respect to the dialogue with the client, support of client participation and dealing with tensions. Contextuallybound information is required, however, with respect to specific learning needs of nurses and conditions present and absent in the care context. The present programme may provide valuable interventions that can be applied in comparable situations.

Further research is warranted into additional interventions aimed at implementation of client-centred care. Additional qualitative studies should investigate the impact of the programme on clients. Finally, it is recommended to assess the impact of interventions on nurses and on clients more frequently and to monitor for lasting impact.

\section{ACKNOWLEDGEMENTS}

We thank all persons involved in the study, especially the clients, the nurses, their managers, the expert clients and the tutors. Data processing was supported by the office for research processing of the Audit \& Control division of Zuyd University. This study was financially supported by ZonMw and by Zuyd University. 


\section{REFERENCES}

Agich, G. J. (2003). Dependence and Autonomy in Old Age: An ethical framework for long-term care. Cambridge: Cambridge University.

Argyris, C. (1991). Teaching smart people how to learn. Harvard Business Review, 69, 99-109.

Bolhuis, S. (2001). Leren en veranderen bij volwassenen (Learning and changing in adults) (Tweede herziene druk ed.). Bussum: Coutinho.

Brug, J., Schaalma, H., Kok, G., Meertens, R. M., \& van der Molen, H. T. (Eds.). (2000). Gezondheidsvoorlichting en gedragsverandering: Een planmatige aanpak (Health counseling and behavioral change: A planned approach). Assen: Van Gorcum.

Cahill, J. (1998). Patient participation: A review of the literature. Journal of Clinical Nursing, 7, 119-128.

Colardyn, D. (Ed.). (2002). Lifelong Learning: which ways forward? Utrecht: LEMMA.

Coulehan, J., \& Williams, P. C. (2003). Conflicting Professional Values in Medical Education. Cambridge Quarterly of Healthcare Ethics, 12, 17-20.

Clouder, L. (2003). Becoming professional: exploring the complexities of professional socialization in health and social care. Learning in Health and Social Care, 2(4), 213-222.

Denzin, N. K., \& Lincoln, Y. S. (Eds.). (2003). Collecting and Interpreting Qualitative Materials (second edition ed.). Thousand Oaks: Sage Publications.

Dochy, F., Heylen, L., \& Van de Mosselaer, H. (2002). Assessment in het onderwijs: nieuwe toetsvormen en examinering in studentgericht onderwijs en competentiegericht onderwijs (Assessment in education: new ways of assessment and examination in student-based and competence-based education). Utrecht: Lemma.

Elwyn, G. (2001). Shared decision making: Patient involvement in clinical practice, Dissertation. Nijmegen: Katholieke Universiteit Nijmegen.

Eraut, M. (1994). Developing Knowledge and Competence. London: Falmer.

Kessels, J., \& Plomp, G. (1999). A systematic and relational approach to obtaining curriculum consistency in corporate education. Journal of Curriculum Studies, 31(6), 679-709.

Kessels, J. W. M. (1993). Towards Design Standards for Curriculum Consistency in Corporate Education. Thesis. Twente University, Enschede.

Kessels, J. W. M. (2004). Nawoord bij 'Het ontwerp van een leertraject in samenspraak' (Epilogue to 'the design of a learning programme in dialogue'. Onderwijs en Gezondheidszorg6).

Kessels, J. W. M. (1996). Succesvol ontwerpen (Succesful Design). Kluwer, Deventer.

Kinmonth, A. L., Spiegal, N., \& Woodcock, A. (1996). Developing a training programme in patient-centred consulting for evaluation in a randomised contolled trial;dibetes care from diagnosis in British primary care. Patient Education and Counseling(29), 75-86.

Latvala, E. (2002). Developing and testing methods for improving patient-oriented mental health care. Journal of Psychiatric and Mental Health Nursing, 9, 41-47.

Leung, W. C. (2002). Competency based medical training: review. BMJ, 325, 693-696. 
Lewin, S. A., Skea, Z. C., Entwistle, V., Zwarenstein, M., \& Dick, J. (2001). Interventions for providers to promote a patient-centred approach in clinical consultations. Cochrane Review.

Onstenk, J. (1997). Lerend leren werken. Brede vakbekwaamheid en integratie van leren, werken en innoveren (Learning while learning to work. Broad competencies and integration oflearning, working, and innovation. Delft: Eburon.

Pill, R., Scott, N. C. H., Rollnick, S. R., \& Rees, M. A. (1998). A randomized controlled trial af an intervention designed to improve the care given in general practice to type II diabetic patients: patient outcomes and professional ability to change behaviour. Family Practice(3), 229-235.

Polit, F., \& Hungler, B. P. (1995). Nursing Research: principles and methods. Philadelphia: J.P.Lippincott Company.

Rijckmans, M. J. M., Garretsen, H. F. I., Bongers, I. M. B., \& van de Goor, L. A. M. (2002). Vraaggerichtheid en vraagsturing. Een poging tot conceptuele verheldering (Demandoriented and demand-driven care: an attempt at conceptual transparency). Tijdschrift voor Sociale Gezondheidszorg, 80, 388-392.

Saunders, P. (1995). Individualized care. Encouraging patients to take part in their own care. Nursing Times, 91(9), 42-43.

Schön, D. A. (1987). Educating the reflective practitioner. San Francisco: Jossey-Bass.

Schoot, T., Engels, J., Hollands, L., \& de Witte, L. (2004). Het ontwerp van een leertraject in samenspraak (The design of a learning programme in dialogue). Onderwijs en Gezondheidszorg(6), 3-10.

Schoot, T., Proot, I., ter Meulen, R., \& de Witte, L. (2005a). Recognition of client values as a basis for tailored care: the view of Dutch expert patients and family caregivers. Scandinavian Journal of Caring Sciences, 19, 169-176.

Schoot, T., Proot, I., ter Meulen, R., \& de Witte, L. (2005b). Actual Interaction and clientcentredness in home-care. Clinical Nursing Research, 14(4), 370-393.

Schoot, T., Proot, I., Legius, M., ter Meulen, R., \& de Witte, L. (2006). Client-centred home care: Balancing between competing responsibilities. Clinical Nursing Research, 15(4), 1-24.

Senge, P. M. (1992). The fifth Discipline: The art \& Practice of the Learning Organization. Milson Point, New South Wales: Random House Australia.

Tillema, H. (1997). Inzicht in competentie-ontwikkeling: Ervaringen met de invoering van performance-assessment intstrumenten in organisaties (Insight into competence development: Experiences with implementing performance asessment instruments in organizations). Opleiding en Ontwikkeling(6), 21-24.

van der Kraan, W. G. M. (2001). Vraaggericht en vraaggestuurd: Een literatuuronderzoek naar vraaggerichtheid en vraagsturing in de gezondheidszorg (Demand-oriented and demand-driven. A review of the literature into demand-oriented and demand-driven care in the health-care sector). The Hague: ZONMw en Erasmus Universiteit Rotterdam.

van Eekelen, I. (2005). De wil om te leren (Readiness to learn) Leren in ontwikkeling, 11 (5). 
van Leeuwen, E. (2005). Ethiek en professie: Competentiegericht ethiekonderwijs aan coassistenten (Ethics and profession: Competency-based education in ethics to medical students who walk the hospital). Tijdschrift voor Gezondheidszorg en Ethiek, 15, 112-116.

Veloski, J. J., Fields, S. K., Boex, L. L., \& Blank, L. L. (2005). Measuring professionalism:a review of studies with instruments reported in the literature between 1982 and 2002. Academic Medicine, 80, 366-370.

Verkerk, M., De Bree, M., \& Jaspers, F. (2004). Visies op professioneel gedrag: Meer nadruk leggen op reflectie en verantwoording (Perspectives on professional behaviour: emphasizing reflection and account for care). Medisch Contact, 59(51), 235-2037. 
9 GENERAL DISCUSSION 


\subsection{INTRODUCTION}

This chapter discusses the results of the studies, first by summarizing the main findings, organized into three parts (section 9.2). Section 9.3 provides a theoretical reflection on some separate parts of this thesis, followed in section 9.4 by a discussion of the contributions of the study in the context of ethics. Section 9.5 evaluates the methodological strengths and limitations of the individual studies. The final section (9.6) examines the implications and recommendations for clinical practice, for education, for policy and for further research.

\subsection{MAIN RESULTS OF THE STUDY}

The research project that underlies this thesis concerned the phenomenon of client-centred care in the home-care setting for chronically ill clients. The goal of the research project was to contribute to the quality of care and the quality of life of chronically ill people. The short-term purposes of the study were twofold: to provide input for a learning programme aimed at developing competencies of home-care nurses needed for client-centred care, and second, to examine whether it is possible to measure and influence the performance of nurses' competencies for giving client-centred care, and how these can be developed. The research project started with the following general questions:

What does client-centred care entail in the context of the primary process of home care for chronically ill clients? Which competencies are required in nurses with respect to client-centred care? And can these competencies further be developed?

The studies discussed in this thesis are organized into three parts, guided by subquestions that are derived from the general questions.

\subsubsection{Perspectives on client-centred care}

Part I of the project concerns the general question what client-centred care encompasses. This was investigated through the sub-questions:

What is the client's perspective on client-centred care?

What is the nurse's perspective on client-centred care?

Client-centred care emerges from the present study as a complex, contextually dependent and relational process in which the client and the nurse participate in a unique way. The interaction process entails the seeking of congruence between participation desired by the client and allowed by the nurse. The way this is given 
shape depends on the client's wishes, values and competencies, and on the nurse's competencies. The studies into the client perspective emphasize care desired by the client, and competencies required in nurses and in clients. The study into the nurse's perspective emphasizes care allowed by the nurse, and also competencies required in clients and in nurses. The nurse's perspective reveals that clientcentred care should not be considered isolated from other roles and responsibilities of the nurse. Effectively balancing between competing responsibilities adds requirements to nurse's competencies for client-centred care.

\section{The client's perspective: Recognition of client values}

In the perspective of expert clients and family caregivers (patient informants of the Dutch Council of the Chronically Ill and the Disabled), recognition emerges as a core category in client-centred care (chapter 2). Client-centred care means an attitude of the professional entailing recognition of the client's values. Client values underlying their demand are: uniqueness (attention for and understanding the client as an individual human being with his/her own life story, beliefs, cultural background and boundaries), comprehensiveness (to be seen as an integral human being, part of a family system), continuity of life (having the opportunity to continue ones life and habits), fairness (being treated as having the right to ask for care needed, and that also less competent and less self-assertive clients get the care they need, autonomy (having the possibility to be who you are, and selfdetermination). Values that turn out to be of interest with respect to the care-relationship: equality (experience- based knowledge is just as valuable and necessary as professional knowledge), partnership (accountable, active, collaborating professionals, with commitment and pleasure in their work; all partners take responsibility, communicate expectations and boundaries, make shared decisions), and interdependence (mutual receptiveness, understanding, trust, acceptance and respect for boundaries). Recognition concerns client feelings of being accepted, respected and being treated seriously. A dialogue as a process, characterized by mutual trust and respect, equality, commitment and partnership, seems an ideal interaction pattern, because it provides a basis for optimal recognition of client values, interests and wishes and for performance of the competencies required for client-centred care (see figure 1). The participants also place requirements on themselves as responsible, interdependent partners in care.

In the perspective of expert clients and family caregivers, nurse's competencies identified with respect to recognition of client values are attentiveness (ongoing attention to know and understand the client, his values and wishes); responsiveness (active, committed and responsible care guided by trust and respect of the client identity); being a critical partner in care (giving and grounding a professional opinion and discussing personal, professional and organizational bound- 


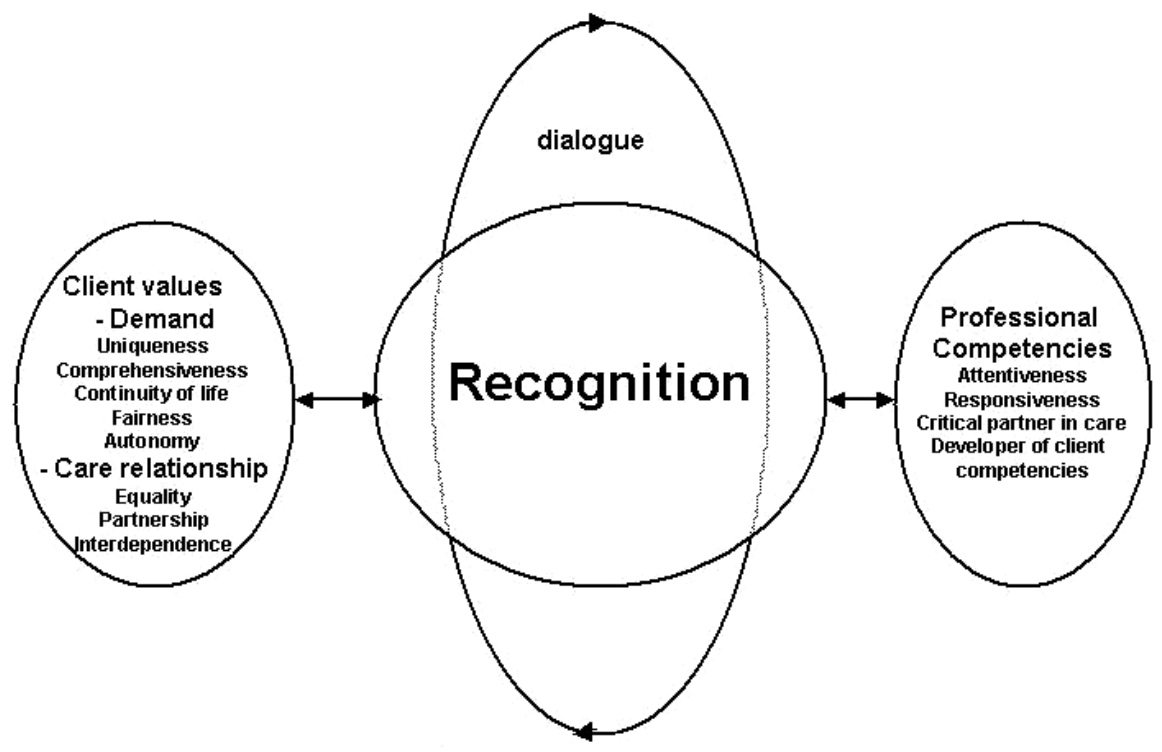

Figure 1. Recognition of client values and nurse's competencies required

aries); and being a developer of client competencies (facilitating and motivating client participation in the care process) (chapter 2).

The client's perspective: Congruence between desired participation and allowed participation

In addition to the perspectives of the expert clients and family caregivers (chapter 2), the study into the client perspective (chapter 3 ) adds information concerning the interaction between nurses and clients with other characteristics (chapter 3).This study makes clear that clients differ with respect to aspects about which, ways along which and the extent to which they desire to participate in the care process. The study revealed factors influencing desired participation by the client, such as client competencies, energy, personality, preferences, beliefs on care, the nature of the demand, coping process, age, and experiences in the past. The findings make also clear that differences exist among nurses with respect to participation allowed. Differences in allowed participation by nurses were closely related to variations in the nurses' performance of competencies for client-centred care (attentiveness, responsiveness, development of client autonomy and being a critical caregiver). Furthermore, allowed participation by nurses was found to be related to client competencies to participate in care, the nurse's values and beliefs concerning both the roles of the nurse and the client and impediments in the work 
environment (e.g. presence of protocols, workload, planning of work processes, and nurse system). Actual interaction appeared to be a two-sided process in time, influenced by desired participation by the client, participation allowed by the nurse, and client competencies to participate in the care process. Six patterns of interaction were distinguished: toeing the line (participation is not as desired by the client, but the client avoids confrontation), reluctance (avoidance by clients of care offered by the nurse), consent (adhering to the opinion and advice of the nurse), dialogue (interactive process between equal, interdependent partners), consuming (active, responsible and self-assertive client directs care desired) and fighting (no participation as desired by the client; the client seeks confrontation) (see figure 2).

\section{Client}

Professional

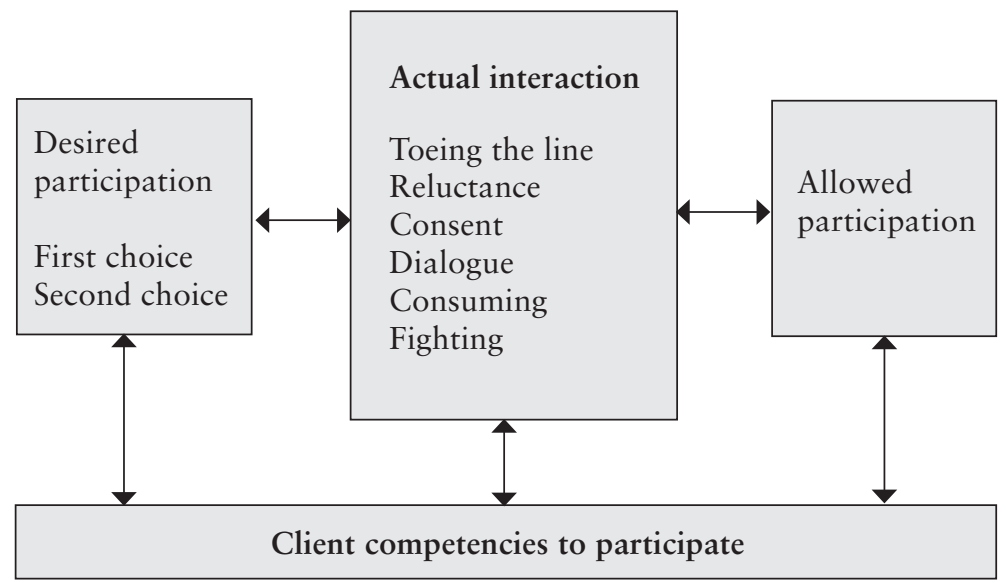

Figure 2. Patterns of actual interaction, desired participation by the client and allowed participation by the nurse.

The findings make clear that the participation desired by the client is not always congruent with the participation allowed by the nurse. Client-centred care emerges from the study as congruence between participation desired by the client and allowed by the nurse. Clients experienced congruence with consent, dialogue and consuming (see figure 3). It can be concluded that variations exist 


\section{Care is client-centred}

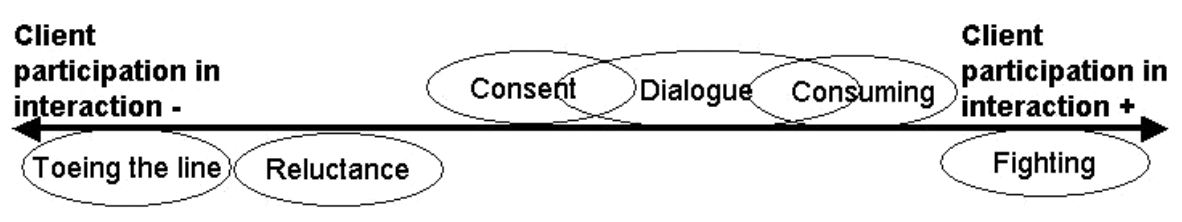

Care is not client-centred

Figure 3. Patterns of actual interaction positioned with respect to client-centred care

among clients, with respect to the meaning attributed to client-centred care. No congruence was experienced with toeing the line, fighting and reluctance.

The nurse's perspective: Balancing between competing responsibilities

The study into the nurse's perspective (chapter 4) towards client-centred care reveals that nurses have more roles and responsibilities than just a role as a responsive professional (meeting the client demand): a critical professional (e.g. evidence-based practice and anticipating long-term problems), a developer of client competencies (e.g. facilitating client autonomy and participation), an individual (keeping individual distance, health and privacy) and an employee of the care organization (responsibility for efficiency, productivity and cost containment). The core category 'competing responsibilities' was identified: that is, responsibilities that compete with the responsibility as a responsive professional. The findings of this study contribute to insight into differences in nurses with respect to balancing between the competing responsibilities, and related differences in the client participation allowed by the nurse. More than one course of action is possible. Choosing to be a responsive professional competes with the other responsibilities and vice versa. Four strategies in dealing with the competing responsibilities were distinguished: pleasing (acting in accordance with the client's demand doing as the client asks; conflicting responsibilities are avoided), dialoguing (actively dealing with competing responsibilities in dialogue with the client), directing (acting in a dominant way, responsibilities as a professional are central), and detaching (the emphasis is on executing the task). Two strategies were also used as second-choice strategies, that is, a strategy that was not preferred in general by the nurse in question: directing as second choice (soft paternalism due to impaired client competencies) and detaching as second choice (orientation to the task due to organizational barriers). In case of detaching as second choice, 


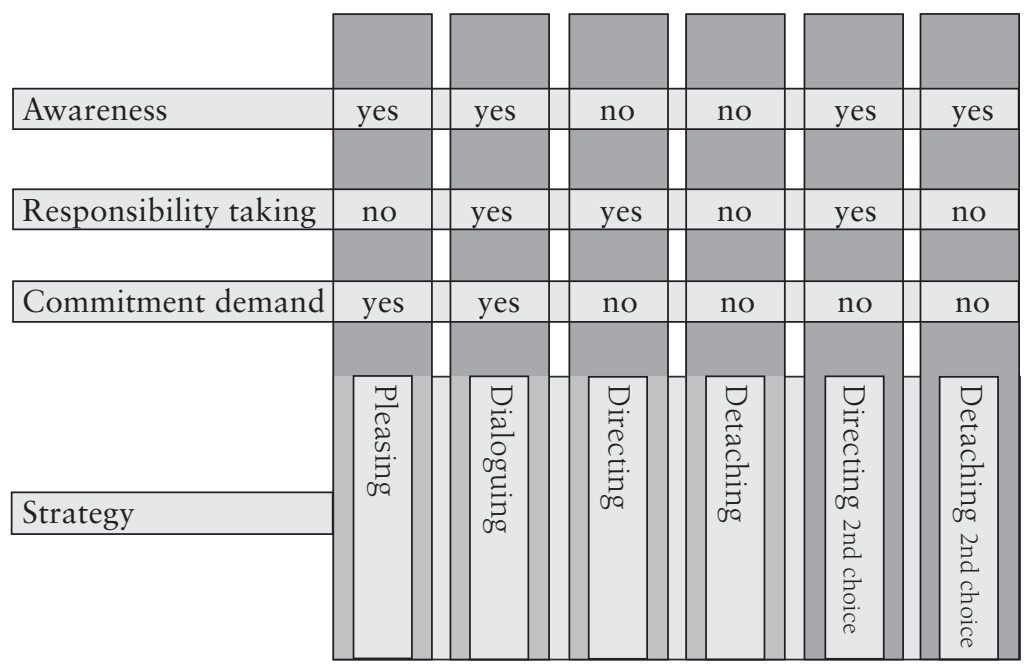

Figure 4. Strategies of nurses in dealing with competing responsibilities, and conditions identified related to the respective strategy.

Yes $=$ Condition was identified

No $=$ Condition was not identified.

the nurses did not feel free to choose the right course of action, because long-term organizational conditions were experienced as barriers. All strategies could be characterized by identification (or not) of conditions related to these strategies: awareness of the competing responsibilities, responsibility taking for competing responsibilities, and commitment to the client demand(see figure 4). The strategies identified could be characterized by consequences: feelings experienced by the nurses, ranging from work satisfaction (strategy dialoguing) to guilt and moral distress (strategy detaching as second choice). All nurses performed more than one strategy, but seemed to have one main strategy.

In nurses performing the strategies pleasing and dialoguing, commitment to the client demand was identified. Awareness of the competing responsibilities and active responsibility taking for competing responsibilities and commitment to the client demand were identified in the strategy dialoguing. This strategy is seen as an effective balance. Nurses demonstrating the strategy 'pleasing', showed commitment to the client demand as well, however, they did not take responsibility for remaining roles and responsibilities, and could not give account of choices made. This seems not effectively balancing between competing responsibilities.

No commitment with the client demand was seen in nurses performing the strategies directing', 'directing as second choice', 'detaching', and 'detaching as second choice'. In the perspective of nurses demonstrating the strategy 'directing 
as second choice', however, nurses were deliberately not committed to the client demand because of the client's impaired competencies to participate in care, as perceived by the nurse. Through this strategy, commitment to client's interests underlying their demand prevailed over commitment to the client demand. Nurses performing this strategy were aware of competing responsibilities and actively took responsibility. Therefore, the strategy 'directing as second choice' is also identified as an effective balance.

It is concluded, that effectively balancing between competing responsibilities is seen in dialoguing and directing as second choice. In these strategies the conditions awareness of the competing responsibilities and active responsibility taking for competing responsibilities are present. The study offers more insight into individual learning needs in nurses.

\subsubsection{Towards a learning programme aimed at client-centred care}

Part II of the study concerns the sub-question:

How can an internally and externally consistent learning programme be developed aimed at development of competencies in nurses with respect to client-centred care?

The answer to this question was sought guided by Kessels's Eight-fields model (Kessels \& Plomp, 1999). The model guided the development of the situation aimed for (in this study client outcomes, nurse competencies and learning situations) and the evaluation of the situation attained (learning processes, competencies in practice and perceived client-centredness) systematically and in close collaboration with central stakeholders. The learning situations (planned learning activities) should enable the nurses to acquire skills, knowledge and attitudes, that influence their performance of competencies in practice, so that it has in impact on clients

Client-centred care, client goals and nurse competencies with respect to clientcentred care were defined in collaboration with a steering committee of central stakeholders and validated by a broad advisory board (chapter 5). Full consensus was achieved. The findings of the studies into the client's perspectives and the nurse's perspectives towards client-centred care (Part I) served as input in this process, by written information, presentations and discussions. Client-centred care was called 'demand-oriented care' by the stakeholders involved. It was defined as:

Care that arises from individual preferences and demands of the client, that is accomplished in a dialogue with the nurse, and in which the client has the final say' 
Client outcomes were defined as:

Expressed feelings by the client of being respected and taken seriously by the caregiver; and of autonomy in the way care decisions are made.

Competencies were defined as the ability to use a set of knowledge, attitudes and skills, in order to perform concrete activities in an adequate way, and in the same time deal with tensions, problems, dilemmas and contradictions encountered in the practice situation (Onstenk, 1997). The particular competencies required for client-centred care were defined as specified in table 1.

Table 1. Core nurse competencies identified with respect to client-centred care

\section{Care process in dialogue}

In dialogue with the patient, the caregiver discusses the care process from the perspective of the patient and on the basis of his or her professional expertise.

\section{Enabling client participation}

The caregiver assists the patient in formulating his or her questions and wishes with respect to entire care provision and encourages the patient to take control of the care process.

\section{Dealing with tensions}

The caregiver is able to deal with any problems and contentious issues that may arise. The caregiver actively seeks out alternative options in the event of tensions between the client perspective and personal, professional and organisational responsibilities.

The competency 'care process in dialogue' covers the competencies attentiveness and responsiveness (chapter 2), and the competencies awareness and commitment to the client demand (chapter 4). The competency 'enabling client participation' covers the competency 'development of client competencies'. 'Care process in dialogue' and 'enabling participation' emphasize relational and communicational aspects of care. The competency ' dealing with tensions' covers the competencies 'being a critical partner in care'(chapter 2), as well as dealing with competing responsibilities (chapter 4). 'Dealing with tensions' emphasizes critical reflection, taking responsibility and giving account for choices, and self assertiveness (see figure 5).

Based upon the competencies identified, a learning programme was systematically developed, guided by the principles of development of competencies. A social constructivist perspective on learning and principles of competency-based education was integrated in the learning activities chosen, such as the emphasis on the nurse's experiences in everyday practice, the emphasis on learning instead of on education, reflection, self- assessment, implementation and transfer of knowledge, attitude and skills in practice (Bolhuis, 2001; Colardyn, 2002, Dochy, Heylen,\& van de Mosselaer, 2002; Eraut, 1994; Onstenk, 1997; Schön, 1987). 


\section{Research study $\longrightarrow$ Learning Programme Part I Part II}

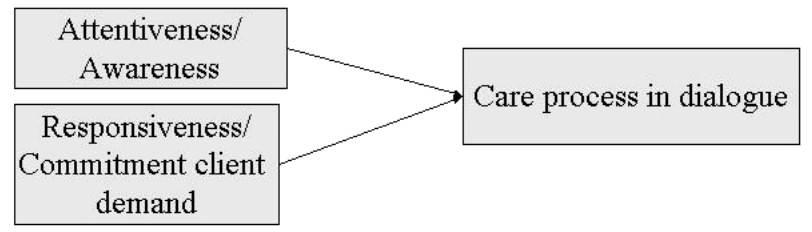

\begin{tabular}{|c|c|}
\hline $\begin{array}{c}\text { Development of } \\
\text { client competencies }\end{array}$ & $\begin{array}{c}\text { Enabling } \\
\text { client participation }\end{array}$ \\
\hline
\end{tabular}

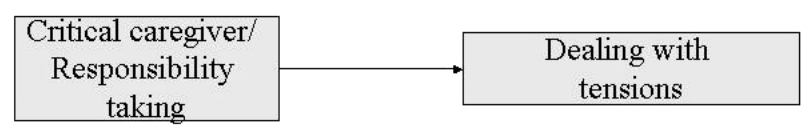

Figure 5: Relationships between competencies as defined in the research study and in the learning propgramme

The entire programme 'Care in Dialogue' consisted of a basic module and an advanced module (for more detailed information about the programme see chapters 5 and 8 ). The basic module (two half-days) was meant for all employees in the care organization (25-40 persons per meeting). It focused on orientation on wishes and demands of clients and awareness of difficulties and barriers in the actual situation. The advanced module (seven half-days) was meant for nurses and auxiliary nurses working in the primary process of care (10-12 per group) who had attended the basic module. The focus was on developing the competencies described. In the first sessions the emphasis was on attitude development and communication, using role plays, feedback and discussions. The final two sessions were follow-up sessions in which critical ethical reflection, accounting for priorities set and self-assertiveness were central by means of presentations of best practices. The programme was offered during working hours. Learning situations were based upon recent practice situations. Application in practice was underscored by a feed-forward and feed-back principle. Nurse academics, experienced in training the elements needed, together with expert clients and family givers were involved as teachers of the programme. The expert clients and family givers played an important role with respect to the nurses' awareness of the client perspective, and of their attitude towards the client and its underlying moral values. This was done by role plays, by expressing their views and giving feed- 
back to the participants. In order to execute the programme as planned, intercollegial trainer-sessions were held.

\subsubsection{Evaluation of the learning programme aimed at client-centred care}

Part III of the project concerns the evaluation of the impact of the programme. The sub-questions were:

How can the nurses' performance of the competencies be measured?

How can client-centredness as perceived by clients be measured?

What is the impact of the learning programme and which factors influence the nurses' development and performance of the competencies?

In this part, the client goals and nurse competencies identified in part II were further operationalized into a self-assessment instrument aimed at measuring performance of nurse competencies in practice, and into an instrument aimed at measuring the client-centred approach as perceived by clients. The instruments were used in the evaluation study of the learning programme. A process evaluation was added because it helps to identify conditions that affect the impact objected and to give appropriate recommendations for implementation.

The measurement instruments were tested in two separate studies.

\section{The evaluation study}

The impact of the learning programme was evaluated at three levels, guided by the Kessels's Eight-fields model: learning processes, performance of competencies and client-centred care as experienced by clients (chapter 8). The process evaluation yielded valuable information about the implementation of clientcentred care in practice. Several factors were identified that constrained the learning processes (lack of time needed, lower education level) and performance in practice (central planning, task-oriented system, workload, lack of support from colleagues and managers). Factors facilitating the learning processes and implementation in practice were feedback from the expert clients and family caregivers, the critical ethical reflection and moral deliberation within the training group, support from an implementation group within the care organization, time and support from colleagues and from the managers.

Findings indicate a positive impact on two of the evaluation levels: the process evaluation and the performance of nurse competencies in practice. No significant statistical impact was observed in clients two months after the end of the programme. A plausible explanation for not having found an impact on clients seems to lie in the fact that only a few nurses were trained, while the clients assessed for perceived client-centred care, received care from several nurses 
(trained or not). Furthermore, the process evaluation revealed that nurses experienced several organizational barriers in performing client-centred care that could not be removed by the nurses' actions. Therefore, the implementation of clientcentred care should not be isolated from policy, structures and processes at other levels of the care organization. It is expected that the impact of the programme on clients will become visible if more nurses attended the programme and if clientcentred care was embedded in the entire care organization.

A learning programme for nurses and auxiliary nurses is available now that seems to have initiated a positive impact on learning processes and development of competencies in nurses with respect to client-centred care. Despite some possible bias, further implementation and testing seems justified. Development of competencies in nurses, however, seems not to be the only and most appropriate solution in all cases. Implementation of client-centred care encompasses more than development of competencies in individual nurses. Support of client-centred care in the primary process needs to be embedded in the attitude, policy, structure and processes of all persons and at all levels of the care organization.

\section{The measurement instruments}

The measurement instruments were developed simultaneously with the programme development. The 'Care in dialogue Competency Scale' is an instrument which aims to delineate the nurses' own competencies in order to give shape to client-centred care in the working situation (chapter 6). The instrument is aimed at nurses and auxiliary nurses who provide care to chronically ill clients and is intended as a self-assessment tool. It consists of three scales. Each scale is an operationalization of the core competencies identified during the development of the learning programme (chapter 5). The scales were tested in a pilot study with nurses and auxiliary nurses of four home care organizations in the south of the Netherlands. For this purpose, the data of the pre-tests of the evaluation study were used as well as the data collected for this purpose in a fourth home care organization. The internal consistency of the three scales was studied by using principal components analysis and by calculating Cronbach's alpha. Seven items of the initial instrument were removed based upon their factor loading. The total (adapted) instrument consists of 29 items. The construct validity, internal consistency and feasibility seem acceptable. The instrument contributes to awareness of competencies needed for client-centred care. Further research is recommended for evaluative purposes of the instrument.

The Client-Centred Care Questionnaire (CCCQ) (chapter 7), is a short and relatively simple tool that can be used to evaluate how clients perceive the clientcentredness of home care. This instrument consists of 15 items, which are an operationalization of the client values identified (chapter 2) and of the client goals 
identified during the development of the learning programme (chapter 5). The instrument can also be used to evaluate effects of interventions aimed at improving client-centred care from a client perspective. Evaluation of clientcentred care from a client perspective is increasingly important. With this questionnaire, home care organizations can evaluate their services. The responses of clients give clues for improving client-centred care.

In general, it can be concluded that, although the studies presented in this part are not robust enough to allow firm generalizations, the first results seem promising.

\subsection{THEORETICAL REFLECTIONS}

Importance of the study

The present study makes clear that client-centred care is not a simple matter of course, but a complex process.

The present study contributes to theoretical insights into the concept of clientcentred care and contributes to the operationalization of the concept of clientcentred care, and of competencies required for client-centred care. The concepts and theoretical hypotheses developed fit within the primary process of home care practice, but need further testing and refining.

A learning programme is available now aimed at development of competencies in nurses, as are measurement instruments into perceived client-centredness by clients and into performance of competencies for client-centred care in practice. The first results of the programme indicate that competencies in nurses can be developed through the programme. Furthermore, the study gives more insight into enabling and constraining factors with respect to the implementation of client-centred care. The measurement instruments seem to offer possibilities for evaluation and self-reflection with respect to client-centred care.

\section{Client-centred care}

In the client perspective client-centred care is about recognition of the client's values, taking into account desired participation by the client, and taking into account client competencies to participate in care. The findings make clear that client-centred care has different faces: under certain conditions it emerges as consuming (the client directs the care), under certain conditions as consent (the professional directs the care), and under certain conditions it emerges as a care process in dialogue with shared responsibility. The dialogue is close to the concepts of demand-oriented care and emotion-oriented care (Goudriaan \& Vaalburg, 1998; Pool, Mostert, \& Schumacher, 2003). Consuming is close to the concept of demand-led care (van der Kraan, 2001). Consent seems closely related 
to soft paternalism (ten Have, ter Meulen \& van Leeuwen, 2003). These findings emphasize the contextually-bound and complex character of client-centred care. A common misunderstanding about client-centred care is that all clients want to have and do benefit from having an active role in their health care participation. The present study reveals that not all clients want, nor are able to participate as 'consumers' in the care process, that is as independent, self-assertive clients, taking full responsibility for their care process. Rather, under certain conditions (e.g. impaired client competencies, anxiety), some clients (temporarily) prefer a more passive role in care. This is the case with the pattern consent. Consent is close to compliance, although the compliance concept does not fit with a client-centred approach, as it often implies client obedience (Burger, 1997). Paternalism may occur when interference with a person's liberty of action is justified by reasons referring exclusively to the welfare, good, happiness, needs, interests, or values of the person being coerced (Dworkin, 1971). Another misunderstanding is that clients 'may not prefer a client-centred approach', and hence a universal adoption would be 'unwise' (Stewart, 2001). According to Stewart, this concern rests on the misconception that being client-centred means sharing all information and all decisions.

The present study emphasizes the importance of a care relationship in order to reveal the client's wishes and demand. This finding is supported by Benner (1984) and by Benner, Tanner \& Chesla (1996). A dialogue is assumed to meet the relational requirements for client-centred care. The dialogue can be characterized as a dynamic process over time. Although in certain circumstances interaction characterized by consent or consuming might be desired by clients, in all patterns, a 'dialogue' in which needs and wishes are (often implicitly) expressed and recognized is seen as an important basis of the care relationship. This is visualized in the overlap of the dialogue with the remaining patterns (see figure 3, section 9.2.1).

At the same time, the study reveals that a provider-oriented approach to nursing care, that is associated with nursing in the past, is alive and well. The findings of this study make explicit the need for nurses to develop their attitude towards the client and towards the care relationship. These findings are supported by Vulto in her plea for a revaluation of care: attention is needed for the intrinsic values of the care relationship, and for a dialogue with the client (Vulto, 2002). Participants value the opinion of a critical, self-assertive professional. Tonkens, (2003) supports these findings. She also aims at repair of the relationship between the client and the professional. She signals that while clients emancipate and become more self-assertive, professionals and professional autonomy have been increasingly tamed. McCormack (2004) states that while it is acknowledged that the demands of everyday nursing practice can often work against a client-centred approach, it is also recognized that there is potential for attitudinal and behav- 
ioural change that could enable this approach to be achieved (McCormack, 2004).

The study into the nurse's perspective emphasizes the complexity of clientcentred care. Effectively balancing between competing responsibilities appeared to be optimal in a dialogue. Effectively balancing does not mean simply allowing the participation desired, and giving priority to the client demand (e.g. pleasing), because among other things, nurses also need to take responsibility for their professional standards and prevent maleficence. Soft paternalism (in directing as second choice) also seems an effective balance between competing responsibilities. Soft paternalism is defined as taking decisions for clients who are not able to take decisions, or as taking decisions for clients who deliberately give the responsibility temporarily to the professional (ten Have et al., 2003). In these situations nurses were aware of competing responsibilities, took responsibility and were acting in a dominant way out of beneficence, because client wishes were judged irrational or against the client's best interests.

Several of the competing responsibilities and strategies identified are described in the literature (Philipsen, 1997; Terpstra, 1997). According to Philipsen (1997), 'appropriate' behaviour of professionals often is regulated and protocolized, based upon scientific evidence and scarcity. Philipsen states that in assessing the demand and in decisions about recognition of a demand, the professional decision should prevail (Philipsen, 1997). Terpstra identifies dilemmas in policy with respect to demand-led care, which are close to the tensions between the competing responsibilities identified. These dilemmas concern the client demand versus scarcity; flexibility versus accessibility; client wishes versus what is assessed as necessary by the professional; and between what is possible and necessary. The concepts awareness and responsibility taking, including giving account for care given, are close to the concept of professionalism. Verkerk, de Bree and Jaspers (2004) state that professionalism is about reflection and account for care decisions in situations characterized by conflicting values.

The Dutch Quality of Care Institutions Act and the Individual Health Care Professions Act, puts requirements to professionals with respect to 'proper care'. Besides client-centredness and care meeting the real client demand, good quality care, effective care and efficient care are mentioned. The present study offers more insight into dealing with these requirements in everyday care for chronically ill clients.

\section{Development of competencies}

The present study offers more insight into competencies required in nurses with respect to client-centred care, and into individual learning needs aimed at effectively balancing between perspectives and responsibilities. 
Several elements of competency-based education were integrated in the programme, such as the emphasis on the nurse's experiences, problems and dilemmas confronted in everyday practice, reflection and self-assessment (Auer, 1994; Bolhuis, 2001; Dochy, Heylen, \& van de Mosselaer, 2002; Onstenk, 1997; Schön, 1987). Participants were encouraged to direct their own learning needs based upon insight into their competencies. Transfer and implementation in practice was given attention by the introduction of structural critical reflection and by the two follow-up sessions (Grol \& Wensing, 2001). Despite these measures, the study makes clear that support of the primary process is needed at all levels of the care organization, and that the entire organization should learn in order to improve its performance. These findings are supported by the work of Argyris, 1991 and Senge, 1992.

The social constructivist perspective chosen in the learning programme offers opportunities to identify values underlying client-centred care in the context of nursing care. A critical question concerns the development of a programme beforehand versus learning on demand by participants. Although many elements of the programme were appreciated as valuable by the participants, individual differences with respect to learning needs have been signalled.

One element remains unresolved: reaching the right participants. Remarks of participants made clear that the programme was attended mainly by participants who were already aware of the need for client-centred care. The challenge is to reach employees who are not aware of the need to change their behaviour (Coulehan \& Williams, 2003). These employees are not ready to learn because they do not experience their attitude as a problem. These employees take either a covert, defensive attitude, or act as victims, not able to find a solution (van Eekelen, 2005).

\section{Measurement instruments}

Unlike measurement instruments aimed at measuring patient-centredness of medical consultations (Mead \& Bower, 2000; Elwyn, 2001), no instruments were found in the literature aimed at measuring client-centred nursing care as experienced by chronically ill clients receiving home care. A critical question concerns the extent to which a complex and contextually bound concept such as clientcentred care can be operationalized into measurement instruments. Focussing on behaviour (as in the Care in dialogue Competency Scale), or on the client perspective (as in the CCCQ) may underestimate the complexity and contextual dependency of client-centred care. Therefore, the results should always be interpreted with caution. According to Verkerk et al. (2004) in addition to the measurement instruments, the emphasis should be on accounting for the choices made in case of conflicting values in a particular context, by means of reflection (Verkerk et al., 2004). The assessment instruments contributed to the learning 
processes in nurses by enhanced awareness in nurses of their attitude and of their care relationship with the client. The instruments offer possibilities for evaluation and self-reflection with respect to client-centred care. Self-reflection is conditional to individual development of competencies and quality of care (Schön, 1987; 2005; Tillema, 1997). The self-assessment scale is closely related to daily practice. Nurses can be stimulated to reflect critically on their behaviour by asking for feedback to colleagues, clients and family caregivers, guided by the instrument. The emphasis is on individual development.

Another possibility of the instruments is the evaluation of the impact of interventions aimed at client-centred care. In these situations, it is recommended to apply simultaneously an instrument to assess client-centredness as perceived by the client, as well as a process evaluation. The instruments would offer possibilities for health care sectors other than just home care.

\subsection{ETHICAL REFLECTIONS}

The findings of the present study emphasize an ethical understanding of concepts and theories with respect to client-centred care. This section discusses the findings of the present empirical study in the context of four main streams in ethics: the four principles approach, an ethic of care, phenomenological ethics and nursing ethics.

\subsubsection{The four principles approach}

Beauchamp and Childress introduced four ethical principles in biomedical ethics (Beauchamp \& Childress, 2001): beneficence, non-maleficence, respect for autonomy and justice. Today, several of the principles mentioned are integrated in laws and guidelines, such as the 'informed consent' procedure (Widdershoven, 2000). The principles approach aims at taking distance from the situation, and at an independent judgement about what should be done in a certain situation from an ethical point of view. Part of the findings of what should be done by nurses in the client's perspective and in the nurse's perspective with respect to clientcentred care appeared to fit with a view of the principles approach.

\section{Client autonomy}

The studies in part I reveal different meanings of the concept of 'autonomy'. One client group valued client-centred care as 'consuming' (chapter 3). These clients were competent, independent, self-assertive clients. They seemed to approve independence and control. To them client autonomy was synonymous with freedom to decide and self-governance. Nurses were expected to accept the client's wishes and choices. This client group seemed to attach value to client 
autonomy as negative freedom (Berlin, 1969). Autonomy as negative freedom points to a liberal view of autonomy, in which non-interference by a third person with the client's or patient's decision-making is central. In care that fits with a model of negative freedom, nurses are not allowed to intervene if the client does not want to or does not give consent to.

Although stressing the merits of a liberal view of autonomy, this study (chapter 2) reveals that clients who are (temporarily) less competent or less self-assertive are at risk of being left to themselves. Respecting the autonomy of chronically ill clients with impaired competencies encompasses more than negative freedom with respect to delineated decisions. Autonomy may concern also being able to give meaning to one's existence. This interpretation of autonomy implies a directive attitude, as nurses could help clients in giving meaning to their existence, particularly being ill and handicapped. Respect for autonomy in this context is called positive, because it is not limited to non-interference, but tries to develop the client's identity (Agich, 2003) and to help him making meaningful decisions instead of leaving him or her alone. The negative and the positive model of autonomy are not mutually exclusive, but are complementary to each other. Negative autonomy gives the patient rights not to be interfered in his or her decision-making, like the right to privacy and the right to refuse treatment, positive autonomy helps the patient to give meaning to the limits set by disease and handicap and to integrate these limits in one's existence (ter Meulen, 2002).

\section{Non-maleficence and beneficence}

The findings of the present study (chapter 2) stress that a paternalist approach is rejected in general, because in this situation the client's values are not recognized or participation desired by the client is not allowed by the nurse. Ten Have et al. (2003) distinguish strong paternalism from soft paternalism. In strong paternalism the professional acts against the wishes made explicit by the client, while the client is able to express his needs and wishes and to understand information. Soft paternalism has been described earlier (see section 9.3) as one-sided decisions for the client justified by reasons referring to the welfare of the client, and justified by impaired client competencies to take decisions (ten Have et al. 2003). In general, non-maleficence, beneficence and a paternalist interpretation of care are associated with medicine in the past and the Hippocratic tradition, an old-fashioned interpretation of care, in which the doctor is the only person who has rights and duties in decision making about care needed. Actually, in this situation there is no need to consider the client's point of view in decision making (van der Arend \& Gastmans, 2002). Though paternalism is heavily criticized by contemporary medical ethics, the present studies (Part I) stress that soft paternalism is still an accepted strategy in practice. Soft paternalism seems to be legitimate and even 
desired by clients under certain circumstances (Ingelfinger, 1985). Also in a study among stroke patients rehabilitating in nursing homes by Proot, Huijer Abu Saad, de Esch-Janssen, Crebolder, and ter Meulen (2000), paternalism has been identified as a facilitating factor regarding client autonomy. In the present study, legitimate circumstances for soft paternalism have been identified with clients valuing the interaction pattern 'consent' as client-centred (in case of anxious clients, or situations requiring new skills or knowledge) and with the nurse strategy directing as second choice, used if the client's wishes were judged irrational or against the client's best interests.

\section{Justice}

The principle of justice concerns the fair distribution of benefits and burdens. This principle is particularly important in the context of scarce resources, like lack of financial means or lack of personnel. In this context the scarce resources have to be distributed according to established standards of justice, like need or medical outcome. Justice appeared to be very close to the value 'fairness' which was found in the present study (chapter 2). Participants stated that they have the right to ask for the care they need. Fairness was at stake with respect to dividing (scarce) time between several clients, and with clients asking more care than was necessary in the nurse's perspective (chapter 4). In the clients' perspectives, fairness also implies that (temporarily) less competent clients get the care needed, even when they are not able to ask for, or do not ask for it (chapter 2). Clients should not be left by themselves. This requires a nurses' role as an advocate for their patients, taking care of procedures in the allocation of scarce resources, including time to support clients or give attention to their needs.

\subsubsection{An ethic of care}

The principles approach, as advocated by Beauchamp \& Childress, is criticized because of its abstract and theoretical character (Widdershoven, 2000). Some of the criticists argue in favour of a more personalized and concrete approach, like the ethics of care. This approach, originally put forward by Joan Tronto (1994) aimes to provide an alternative for the principles approach. Gastmans \& Vanlaere try to develop an ethics of care in which an anthropological basis is supplied for ethical evaluation (Gastmans \& Vanlaere, 2003). Instead of distance and applying abstract and universal moral principles, contextual knowledge based upon personal experiences and requirements with respect to the care situation are central (Houtepen \& Smits, 1993). An ethic of care emphasizes mutual involvement, respect and trust in the care relationship (Little, 1998; Verkerk, 2003). Core concepts in an ethic of care are responsibility for, commitment, involvement, mortality, and communication (Gastmans \& Vanlaere, 2003). 
All three studies in part I of this thesis appeared to be strongly related to an ethic of care. The values with respect to the care relationship (chapter 2), 'equality', 'interdependence concerning trust and respect' and 'partnership' are in line with the requirements with respect to the care relationship, mentioned as central in an ethic of care. The present study adds explicitly 'recognition of client values' as a new ethical concept to the care relationship. O'Neill (2002) also emphasizes the importance of trust in the care relationship. She suggests that the concept of individual autonomy is ethically inadequate and undermines rather than supports a relation of trust. She states that, while traditional trust, associated with a paternalist approach has vanished, a new kind of trust needs to be developed based on rights of patients on the one hand and professional autonomy on the other hand (O’Neill, 2002).

The present study reveals that in client-centred care nurses need to find a balance between perspectives and responsibilities. An ethic of care offers opportunities to find a balance, based upon the care relationship with the client. In Tronto's (1994) opinion, care is a process and a practice. She distinguishes four elements of care: caring about, taking care of, care-giving and care-receiving. From these elements, she extracts four ethical elements of care: attentiveness, responsibility and competence with nurses; and responsiveness with the client. The competencies for client-centred care, identified in the present study, are very close to Tronto's ethical elements of care.

\subsubsection{Phenomenological ethics}

The study concerning interaction (chapter 3) reveals that interaction and the care relationship seem to be of great importance for clients. Desired participation and hence the care relationship desired by the client differ. Congruence between the client's and the nurse's perspective on care and the care relationship is central in client-centred care. Dialogue was identified as a pattern to optimally identify and recognize client values. Dialogue offers possibilities for autonomy as positive freedom (Berlin 1969). Freedom to choose and self-governance, as seen with the interaction pattern consuming in this study, fit with autonomy as negative freedom. The pattern 'dialoguing' as discovered in this study, points to autonomy as identification (Agich, 2003) and to autonomy as communication (Moody, 1992). Agich emphasizes the contextual and dynamic character of autonomy in interaction with other persons. According to Agich, a person is autonomous if he can identify with whom he has become, or is becoming. This implies that autonomy is not static, but changes over time. On the basis of phenomenological philosophy, Agich stresses the importance of identification with one's personal 
circumstances and with the limits set by one's disease (Agich, 2003). Care that fits with the view of autonomy as identification helps the client to express and develop his individuality, and to give an individual meaning to his existence. Moody questions the traditional view on decision making as informed consent. Instead, he considers care as long-term processes characterized by consensus and conflict, and he emphasizes 'negotiated consent'. According to Moody, communication processes are more important than applying abstract principles such as respect for autonomy. Negotiated consent implies trying to motivate the client to participate in the care process and to exchange and confront perspectives. Widdershoven (2000) states that in the views of Agich and Moody, autonomy as the right of non-interference is rejected, and that in these views an alternative for the model of negative autonomy is offered. The finding in the present study of different interaction patterns desired by clients supports the view of autonomy as identification and communication. Several authors stress the importance of a dialogue as a mode to enhance clients' self-understanding and self-determination (Agich, 2003; Emmanuel \& Emmanuel, 1992; Pool, Mostert, \& Schumacher, 2003). A social concept of autonomy emphasizes the contextual character of autonomy: client autonomy can only be realized in relation with another person, that is in the relationship between care provider and care recipient. . We can conclude that the findings of the present study are in line with, and contribute to the understanding of an individual concept of autonomy (Beauchamp \& Childress, 2001) as well as with a social concept of autonomy (Proot, Crebolder, Huijer Abu Saad, \& ter Meulen, 1998).

According to Agich and Moody, care should offer opportunities for the nurse to intervene in decisions about care. If a client refuses help, as a result of a lack of insight into his situation, as seen in the pattern 'reluctance' (Chapter 3), nurses are allowed to intervene, provided that the intervention aims at enhanced control by the client (Widdershoven, 1998). The emphasis on the care relationship makes clear that care cannot be reduced to a product 'sold in the health care market', because in that situation the intrinsic values mentioned are not respected.

\subsubsection{Nursing ethics}

Nursing ethics is considered to be a distinct field within health care ethics, dealing with ethical questions specific to nursing. Today, attention for nursing ethics in practice is increasing. It is not just the 'big issues' such as euthanasia that are experienced as ethical problems in the perspectives of nurses, but the everyday problems such as acting against the client's demand are too (van der Arend \& Remmers-van den Hurk, 1999). Several authors discuss the possibilities of nursing ethics to deal with (everyday) moral questions of nurses (Gastmans \& Vanlaere, 2003; Jansen, 
2005; Smits, 1996). One of the central issues in an ethic of nursing is the role and position of the nurse with respect to patient care and the contact with the patient (Gastmans \& Vanlaere, 2003). Particularly nurses giving care to chronically ill clients focus on the every-day care process in close interaction with the client and other persons involved. The concepts found in this thesis, such as recognition of client values, attentiveness, responsiveness, being a critical caregiver, developer of client competencies, awareness, responsibility taking and commitment with client interests (chapter 4), contribute to insight into the complexity of longterm care and of the nurse's role in client-centred care.

The various concepts mentioned stress the nurse's role as a responsive professional to the client demand. Patient advocacy is a concept closely related to the responsibility of being a responsive professional. A patient advocate is a term defined as the process of giving support to a client and, if necessary, representing a client or partner in all situations in which there is a need for nursing help aimed at protecting the client's rights or make a stand for the client's interests (Gates, 1994). Client advocacy is described as moral task in many professional codes for nursing practice. Van der Arend questions the nurses' role as a client advocate. He estimates that the concept takes insufficient account of potentially conflicting loyalties (van der Arend, 2003). The findings in the present study of roles and responsibilities competing with the role as a responsive professional (chapter 4) underscore this opinion and emphasize the moral responsibility of nurses towards themselves, clients, care organization and other stakeholders involved. The study reveals that the nurse's role with respect to client-centred care can raise moral conflicts within the nurse. These conflicts need to be understood in the context of everyday practice, the institutional setting and the patient demands.

\subsubsection{Conclusion}

In the past decade, there is more emphasis on empirical studies in the field of health ethics. At the moment various empirical studies on ethical issues in health care and social care are available. Hope (1999) emphasizes the possibilities of empirical ethics to enrich the subject of philosophical ethics. Also van Delden, van der Scheer, van Thiel and Widdershoven (2005) signal an increased interest of ethicists internationally, with respect to empirical research.

In this section, the findings of the present study have been discussed with respect to four main streams in ethics: the four principles approach, an ethic of care, phenomenological ethics and nursing ethics. On the one hand, ethical concepts and theories helped in the theoretical understanding and moral underpinning of the findings of the present study with respect to client-centred care. On the other hand, findings of the present study may contribute to ethical concept develop- 
ment and theory development. It can be concluded that a principles approach is essential to understand and guide practice, but is not sufficient. A principles approach contributes to understanding and dealing with specific problems and situations, from a distant and independent point of view. An ethic of care and an ethic of nursing seem to offer additional ethical concepts and theories that help to understand the reciprocal nature of everyday nursing care. The liberal and phenomenological approaches on respect for autonomy are complementary: they both give guidance in helping the client to realize his autonomy in constraining circumstances. However, if it comes to understanding of the client's needs, the phenomenological approach and the ethics of care are indispensable and offer a more adequate approach than the concept of autonomy as negative freedom in which non-interference with the client is dominant.

\subsection{METHODOLOGICAL REFLECTIONS}

The studies discussed consisted of a mixture of qualitative and quantitative research methods. In order to explore the perspectives of clients and nurses, a qualitative research method was chosen. The evaluation studies were based upon both qualitative and quantitative methods. The combination of qualitative and quantitative methods and the use of different methods for data-collection is expected to have strengthened the design (Pope \& Mays, 1995). Finally, the combination of education and research can be seen as an example of mutual enforcement of possibilities.

\subsubsection{Qualitative studies}

Qualitative research needs to be evaluated and judged within the qualitative tradition, with proper criteria for qualitative research (Cutcliffe \& McKenna, 1999). The trustworthiness of the study can be evaluated based upon the following criteria: credibility, transferability, dependability and confirmability (van der Lyke \& Proot, 2004; Lincoln \& Guba, 1985; Strauss \& Corbin, 1998).

\section{Strengths}

The validity of the study places requirements on the appropriateness of the design and methods chosen, and ethical considerations. Qualitative research is chosen when little is known about the phenomenon under study. This was the case in this study where a qualitative research method was chosen in order to explore the phenomenon of client-centred care in the context of home care for chronically ill clients. The optimal way to study client-centred care in the primary process of care is to do so from the point of view of the clients and nurses affected (Little et al., 
2001). Grounded theory provides strategies for developing concepts and theories that fit into a particular field of practice. This may contribute to the use of recommendations of the study by professionals (May, 1990; Strauss \& Corbin, 1998). Ethical considerations such as the informed consent procedure with clients and guarantees with respect to the anonymity and privacy of clients and nurses contributed to the validity of the findings.

A few additional measures were taken to improve the trustworthiness of the study. Credibility was emphasized by triangulation of methods for data collection. A substantial part of the data was collected by focus interviews and individual interviews. This is important, because with these methods, participants use their own words. Several measures were taken to guarantee the independence of the participants. Furthermore, categories chosen to organize the results were based upon the views of the participants. As a result, the theory was built inductively. During the start of the analysis phases, the codes used were as close to the data as possible. Theoretical sampling was applied guided by 'deviating findings' after constant comparison. Member checking, memos and peer debriefing with the other researchers involved contributed to the credibility of the studies. In the later phases of the analysis, the findings were compared with existing literature.

Attention was paid to dependability and confirmability by member checking and peer reviewing. Member checking was performed with the participants of the focus interviews, by the construction of a first-draft report of both focus interviews, which was sent for commentary to all participants. Peer review was performed by triangulation of researchers. At least three researchers were involved in the data analysis of each study. All data were coded independently by two of the researchers involved, and subsequently discussed. Additionally, insight into the research process emerged by describing comprehensively the steps taken, the findings and the relationships found.

Unlike generalizability of quantitative studies, qualitative studies can be judged on their explanatory power and transferability of the findings. Explanatory power means predictive ability, that is the ability to explain what might happen in given situations. The explanatory power of the present study concerns the conditions that gave rise to the phenomena described (interaction between clients and nurses with respect to client-centre care), the strategies used by clients and nurses, and the consequences of the strategies used in the context of chronically ill people, receiving long-term care from nurses at home. Given the systematic and purposeful theoretical sampling, and the accurate description of the characteristics of the population under study, it is estimated that the explanatory power and transferability of the findings is acceptable to good. Nevertheless, the emphasis was on nursing situations with female nurses with a Bachelor's degree. This may have consequences for the explanatory power in this respect. Additional sampling for situations and events with lower educated nurses and with male nurses would 
have given more strengths with respect to these particular groups. With respect to reproducibility it is expected that, given the same theoretical perspective of the present researchers, following the same rules for data gathering and data analysis, and assuming a similar set of conditions, other researchers should be able to come up with a very similar theoretical explanation about the phenomenon under investigation (Strauss \& Corbin 1998).

The identification of competencies required in nurses and the development of the programme were guided by Kessels's Eight-fields model (chapter 5) (Kessels \& Plomp, 1999). This framework provided a valuable and flexible structure to organize and align discussions and activities of the multidisciplinary stakeholders involved. The strengths of this study are the internal and external validity achieved by the systematic method applied, and the external validity provided by a multidisciplinary steering committee and a broad national advisory board (Kessels, 2004).

\section{Limitations}

A qualitative design like grounded theory is an adequate design to explore and describe the phenomenon of client-centred care. It cannot be used, however, to test for significant differences between client groups, or nurses with specific characteristics, or for differences between care organizations. Few male expert patients and male nurses participated in the study. The participation of auxiliary nurses was limited. As stated before, this may have impact on the explanatory power of the findings in this respect.

The methodology provided an understanding of the participants' world as they view it. The present study emphasized exploration and description of the phenomena under study. Several concepts and theoretical hypotheses were developed. Nevertheless additional research is necessary with respect to the theoretical concepts developed, the relationships between the concepts, and the development of normative guidelines for nurses.

Grounded theory methodology was used to study an unexplored phenomenon, client-centred care in the context of home care. This methodology implies an open start. In order to prevent researcher bias, an attempt was made to see the phenomenon under study as new, setting aside previous thoughts, perceptions, and experiences with it. From this point of view, the past experiences of the researcher as a community nurse, can be seen as a limitation of the study. According to Glaser (1978), however, professional experience can help make the researcher theoretically sensitive. Nevertheless, as described previously, several measures were taken to minimize researcher bias, and to increase the credibility, dependability and confirmability of the studies. There were no indications that participants' answers could have been influenced by social desirability. On the contrary, participants (both clients and nurses) revealed their doubts and ques- 
tions during the interviews and observations. The choice of two different methods (participatory observations and interviews) offered the opportunity to broaden the description of situations and events.

A limitation of the programme development (chapter 5) was the restriction of the promotion of client-centred care to development of competencies in nurses (Kessels, 2004). Although attempts were made to influence colleagues and managers via the participants of the training, the results indicate that a corporate approach, encompassing employees, processes and structures of the entire care organization would probably have been more effective. A constraining factor was the tension between the time needed for proper analysis of qualitative data on the one hand, and the pressure of time during the development of the learning programme on the other. Furthermore, despite some measurements taken to improve transfer and implementation, it should be acknowledged that additional follow-up sessions to reinforce the processes intended would have improved the implementation in practice. Finally, a critical question concerns the development of a programme beforehand versus the principle oflearning on demand by participants. Although many elements of the programme were valued by the participants, differences were signalized with respect to learning needs. A standardized programme should be avoided, and the learning programme should sufficiently meet individual differences with respect to learning needs.

\subsubsection{Quantitative studies}

The evaluation part consists of the development and testing of the measurement instruments (chapters 6 and 7) and the evaluation of the impact of the programme on competencies and on client-centredness as experienced by clients (chapter 8). Apart from the evaluation study, these studies consisted of quantitative elements.

\section{Strengths}

With respect to the evaluation study (chapter 8), an experimental design with participants randomly assigned to the intervention group and a control group to evaluate the impact of the training was not appropriate for two main reasons: the institutions had strategic interests in training specific nurses, and the programme was designed to have an optimal impact on all professionals and their clients of the organization. With Kessels's Eight-fields model, an empirically tested model was found that was applicable for evaluation at three levels, acceptable and applicable in the field of practice. The strength of the present study was the multiple evaluation at three levels, evaluating the perspectives of both clients and nurses with different methods and instruments. The process evaluation of the programme was 
based upon triangulation of methods (Denzin \&Lincoln, 2003). Both qualitative and quantitative data were collected.

Assessing a complex and contextually dependent concept such as client-centred care poses many challenges. The framework used directed evaluation of the programme at three levels with a mix of instruments. The content validity of the measurement instruments (chapters 6 and 7) was provided by the input of the qualitative studies discussed in chapters 2-4. As described in chapter 5, client representatives, nurses and their managers were systematically involved in identifying the competencies needed for client-centred care. In this way, account can be given for standards underlying the instruments.

To meet individual differences in clients with respect to expectations, needs, capabilities and wishes, the items in the client instrument (CCCQ) were formulated in such a way that clients varying with respect to participation in care desired could answer the questions.

Self-assessment is criticized because a lack of competency will not be signalized in case of unawareness. In order to avoid this problem, the items of the competency scale were formulated in terms of behaviour. The formulation of items in terms of concrete behaviour also aimed at the prevention of response shift related moral development in nurses.

No indications were found of special attention to competence development with respect to client-centred care in the distinct care organizations, nor in the distinct educational curricula for nurses and auxiliary nurses. Therefore, the testing of the construct validity of the competency scale was partly based on the hypothesis of an absence of a correlation between competencies and the different care organizations and background variables in nurses such as education. At the same time, differences in perceived client-centredness by clients in the different care organizations were expected, because the evaluation study made clear, that clientcentred care is also related to other aspects of client-centred care (e.g. number of nurses involved in care for one client, attainability) and does not only entail performance of competencies by nurses. These correlations will stay invisible, however, in case of a lack of responsiveness of the client instrument developed. Therefore, additional testing of the responsiveness of the instruments developed is warranted.

In order to prevent measurement errors (e.g. situational bias, and social desirability) as much as possible, the assessments with the competency scale were anonymized and incorporated into the education programme (Polit \& Hungler, 1995). It was estimated that, in this way, the participants might be less aware of the research context. 


\section{Limitations}

A constraining factor of the evaluation study was the gap between requirements with respect to scientific research on the one hand and reality of practice (e.g. implementation strategies, time constraints, and restrictions by the care organizations) on the other hand (Kessels, 2004).

An explanation for the absence of an impact on clients may be related to methodological issues. Firstly, only a few nurses were trained, while the clients assessed received care from several nurses. The rationale for the selection of only 1-2 nurses per team was that managers expected transfer and implementation of the competencies acquired by the nurses to the other members of the team. This effect appeared to be over-estimated, as the process evaluation revealed that participating nurses found it difficult to influence the attitudes of colleagues. Secondly, the duration of the study may have been too short to detect a change. The planning of the post-test for clients two months after the end of the course may have been too soon to give the nurses the opportunity to apply the competencies developed in practice and to transfer the competencies needed to colleagues who also provide care for the clients. The evaluation study should be viewed with caution in the absence of a control group. A limitation concerns selection bias in nurses. The fact that managers have selected some of the participants may have lead to selection bias. It is not known whether the programme would also show positive changes with less motivated participants. In general, it can be concluded that, although the studies presented in this part are not robust enough to allow firm generalizations, the first results seem promising. Finally, it should be acknowledged that additional qualitative methods to investigate clientcentred care as perceived by clients, and performed by nurses, as well as repetitive measurements in nurses and clients would have strengthened the design. Despite the possible bias described, a significant change was found at the post-test of the evaluation study. with respect to competencies in nurses. A critical question concerns the lasting impact of the competencies developed. Despite some measures taken to improve transfer and implementation, it should be acknowledged that additional measurements to assess for lasting impact would have strengthened the design.

There are some limitations of the studies on the measurement instruments that should be taken into account when interpreting the results. First, the study on the client instrument, the Client-Centred Care Questionnaire (CCCQ). The response in clients was very low. Nothing is known about selection of these respondents, except for the fact that they are unequally distributed over the participating organisations. This is not seen as a problem, because the analysis only concerned the total group. A potential problem when using the CCCQ to measure changes might be the low responsiveness to changes. Whether this is 
problematic or not has to be studied in a new study with repeated measurements. Client attrition could be attributed in most cases to natural events such as death or hospital admission. Therefore it is not likely that this influenced the results. The score of the group aimed at control for selection bias in clients was similar to that of the evaluation group before the programme. Hence, selection bias is unlikely. The CCCQ has to be further tested in populations with other characteristics and in other organizations. For descriptive purposes, however, the present results provide sufficient reliability.

Second, the study on the nurse instrument, the Care in dialogue Competency Scale (Competency Scale). The sample size with respect to the competency 'care process in dialogue' was too small for a principal components analysis. The loading of the items concerning decision making on this factor needs further investigation. Furthermore, the number of auxiliary nurses involved in the study was relatively small. Social desirability may have played a role, as people have a tendency to present themselves in the best light, and this may conflict with the truth (Polit \& Hungler, 1995). Despite the measures taken (anonymity, questions in terms of behaviour, integration into the learning programme), the pre-test scores may have been biased. This is confirmed by the process evaluation of the evaluation study. The participants estimated themselves as more client-centred before the programme than they were in reality. It is expected, however that under the condition of repeated measurements, self-assessment can add valuable information to the evaluation of client-centred care. A critical question concerns the relationship between competence development in nurses and education level. This needs further investigation. The construct validity, internal consistency and responsiveness of the instruments developed need further testing.

\subsection{IMPLICATIONS AND RECOMMENDATIONS}

In this section, implications and recommendations for clinical practice, for education, for policy and for further research will be discussed.

\subsubsection{Recommendations for clinical practice}

Recommendations for clinical practice aim at finding a balance between perspectives and responsibilities by a relational approach, a contextual approach and critical ethical reflection.

\section{A contextual approach}

Client-centred care in the primary process of care is not a trick. Client-centred care cannot be uniform in each situation, because of differences in client's wishes and competencies and contextual differences. Client-centred care is given shape 
in a process, together with the client in his context. Clients differ with respect to competencies and to participation desired. Enabling and facilitating the participation desired by the client is recommended. This may imply that client participation is stimulated and encouraged. Nevertheless, client participation is not a must. Clients with impaired competencies may prefer (temporarily) a more passive role in care. Legitimate circumstances for soft paternalism seem to be clients who are not competent to take care decisions and clients who deliberately give the responsibility for care to the nurse.

\section{A relational approach}

Client-centred care in the primary process of care is given shape in a process in relationship with the client. Therefore, it is important to know the client, his environment and narrative. Nurses should make sure that they are aware of the client's values with respect to his or her demand and with respect to the care relationship. This implies ongoing attentiveness to client values and wishes and enabling mutual involvement, respect and trust in the care relationship. Nurses should realize that client wishes and competencies to be involved in care can change. Furthermore, not all clients are (always) competent to express their demand accurately. In such a situation, client wishes need an interpretation. Knowing the client is a precondition to interpret client wishes. Being responsive to client values and wishes is recommended. This starts with awareness, and recognition of client values and wishes. Furthermore, taking responsibility for the client demand is essential. This may also imply a role as a client advocate.

\section{Critical ethical reflection and moral deliberation}

Client-centred care is not doing gratuitously what the client wants, but listening carefully, giving and grounding a professional opinion as a partner in care, being creative and flexible, setting personal, professional and organizational boundaries, and being self-assertive at the same time. Sometimes, this implies 'to contradict the client'. Giving client-centred care implies fostering critical ethical reflection. Moral deliberation with colleagues and team members is recommended. This should encompass the application of ethical principles (autonomy, beneficence, and justice) in particular care situations, as well as values underlying the care relationship, (competing) responsibilities, and strategies chosen in the specific context. It is expected that ethical reflection and moral deliberation will increase awareness of the care relationship, of competing responsibilities and will support efforts to find a balance.

Finally, asking for feedback from the client, family caregiver, colleagues and manager with respect to client-centred care is recommended. It is recommended to use the instruments developed as tools in reflection and feedback. 


\subsubsection{Recommendations for education}

Development of competencies in nurses

It is recommended to develop the three core competencies for client-centred care in nurses:

- A care process in dialogue: In dialogue with the client, the caregiver discusses the care process from the perspective of the client and on the basis of his or her professional expertise.

- Enabling client participation: The nurse assists the client in formulating his or her questions and wishes with respect to entire care provision and encourages the patient to take control of the care process.

- Dealing with tensions: The nurse is able to deal with any problems and contentious issues that may arise. The caregiver actively seeks out alternative options in the event of personal, professional and organizational shortcomings.

\section{Attitude development}

It should be stressed that saying that client-centred care is needed and labelling things in a new way is not enough. A shift in understanding and a change of attitude is needed. This requires not only new changes among nurses, but with all employees directly, or indirectly related to care for clients. Not all persons involved in care for chronically ill clients are aware of the meaning of clientcentred care for clients. Recognition of willingness or unwillingness to develop competencies required for client-centred care is important in choosing appropriate interventions. If persons are not aware of the need to change, thinking 'we already are client-centred', participation in an education programme might not to be the most effective intervention. In these situations, 'on the job' coaching is recommended (van Eekelen, 2005). Furthermore, the manager (and in turn the manager of the manager) should discuss the desired attitude with the employee on a regular basis, and to encourage the employee to apply the attitude desired.

\section{Nurse-centred education}

Nurses differ with respect to competencies to be developed. Therefore, it is recommended to better tailor the specific interventions to the individual nurses' demands. The learning programme 'care in dialogue' is recommended for nurses who want to develop their competencies for client-centred care. In order to develop competencies effectively, improving responsibility taking among less assertive nurses is recommended through specific training in assertiveness. It is recommended that nurses obtain more professional autonomy in dealing with competing responsibilities. 


\subsubsection{Recommendations for policy of home care organizations}

Client-centred care is a complex concept consisting of different perspectives, levels, aspects and degrees. Confusion in discussions can be prevented by clarifying and defining beforehand what is meant. It is recommended to avoid conceptual discussions. Instead, when discussing client-centred care, it is recommended to clarify the underlying perspective (such as political, economic, institutional, client, professional), central level (primary process, meso level, macro level) and central aspects of client-centred care (such as decision making, planning, financing) of the theme discussed.

\section{Implementation}

Executing a project aimed at the implementation of client-centred care by a few selected nurses is not enough. Client-centred care should be embedded in all levels of the care organization. It is recommended to enhance awareness with respect to client-centred care and its underlying values in all employees of the care organization by communication about experiences and expectations on a regular basis. Implementing client-centred care ought to encourage all employees to reflect critically on their beliefs and moral values on a regular basis. Ongoing, integral, structural and organizational changes are required. For example the mission statement of the care organization, job descriptions, policies and procedures, and the organization of care processes should be evaluated critically with respect to the principles of client-centred care. The arrangement of structural 'transfer sessions' in which nurses learn from eachothers's experiences and best practices is recommended.

\section{Support of the primary process}

Managers should be aware that client-centred care in the primary process of care needs support. This requires first of all encouragement and moral support of nurses to give client-centred care. To become aware of tension fields experienced by nurses in giving client-centred care, and in order to give the support needed, participation of managers in the dialogue and in critical reflection with nurses is recommended. Taking measures aimed at enhanced professional autonomy in dealing with competing responsibilities is recommended. Providing facilities to promote development of competencies tailored to the nurses' demand is recommended. Sustaining measures with respect to structure and processes at all levels in the care organization (e.g. a primary nurse system, decentralized planning) are recommended. It is recommended to provide managers with the support needed. 
Enhancement of professional autonomy

Considering care as a product, instead of as a care relationship is estimated to have a negative effect on finding a balance between care provided and the client's needs and wishes. Considering all clients as competent partners in care can have negative consequences for (temporarily) less competent clients, such as not getting the care that is wanted or needed. Client-centred care is a complex issue. A relational approach is needed to find a balance between the client's needs and demands and organizational and societal restrictions. A central assessment centre granting standardized functions instead of granting care that is needed by an individual client in a particular context, is an undesirable situation from the point of view of clientcentred care. Enhancement of professional autonomy in taking decisions about the content and amount of care is recommended, provided that the nurse knows the client and his context, and provided that nurse is aware of and takes responsibility for competing responsibilities.

\subsubsection{Recommendations for policy of client organizations}

Client organizations are likely to present clients as independent, competent and self-assertive consumers, taking full responsibility to direct their care process. The relational and contextual meaning of client-centred care stresses the individual differences of clients in their situation. The present study reveals that not all clients are competent nor do they want to be independent, self-assertive consumers, taking full responsibility for their care process. It is recommended to patient organizations to distinguish differences in clients' needs and wishes with respect to participation desired. Clients want to be partners in the care process in different ways.

\subsubsection{Recommendations for future research}

Further empirical research aimed at developing and testing concepts and theories central in client-centred care is recommended. Recommendations can be made based upon all three parts of this dissertation.

With respect to part I of this dissertation, further research into the theoretical concepts developed and their relationships is recommended. In addition, an investigation of the perspectives with respect to client-centred care of clients and nurses and nurse's aids in the context of acute care is recommended. Furthermore, studies on nurses balancing between the competing responsibilities with respect to client-centred care, and on work satisfaction and moral distress experienced in nurses are warranted. Finally, research into the development of normative guidelines for nurses, and into the development of moral values in nurses is recommended. 
With respect to part II of this dissertation, it is recommended to develop and pretest additional interventions aimed at the implementation and support of clientcentred care for nurses and for employees other than nurses, such as managers. Possible interventions are: the introduction of problem-based methods and of attitude-oriented methods of moral deliberation to discuss ethical problems with nurses, management training aimed at increased support of nurses, the introduction of 'transfer sessions' in which nurses learn from eachothers's experiences, and enhancement of professional autonomy in taking care decisions with the client.

With respect to part III, it is recommended to further test the reliability, validity and responsiveness of the instruments developed, also in populations with other characteristics and in care organizations other than home care, such as residential care and clinical care. Further research into competence development and background variables in nurses, such as education level, is also warranted. For future evaluations of client-centred care in clients and nurses, it is recommended to include repetitive measurements with the instruments developed, and to add qualitative methods for data collection concerning experiences with care.

\section{REFERENCES}

Agich, G. J. (2003). Dependence and Autonomy in Old Age: An ethical framework for long-term care. Cambridge: Cambridge University.

Argyris, C. (1991). Teaching smart people how to learn. Harvard Business Review, 69, 99-109.

Auer, C. (Ed.). (1994). Opleiders in Organisaties, Capita Selecta (Educators in Organizations: Capita Selecta), 20. Deventer: Kluwer Bedrijfswetenschappen.

Beauchamp, T. L., \& Childress, J. F. (2001). Principles of biomedical ethics. Fifth edition. Oxford: Oxford Univerity Press.

Benner, P. (1984). From novice to expert. Excellence and Power in Clinical Nursing Practice: Addison/-Wesley Publishing Company.

Benner, P., Tanner, C. A., \& Chesla, C. A. (1996). Expertise in nirsing practice: Caring, Clinical Judgement and ethics. New York: Springer Publishing Company Inc.

Berlin, I. (1969). Two concepts of liberty. Four essays on liberty. Oxford: Oxford University Press.

Bolhuis, S. (2001). Leren en veranderen bij volwassenen (Learning and changing in adults) (Tweede herziene druk ed.). Bussum: Coutinho.

Burger, W. (1997). The relation between medical education and medical profession's world view. Medicine, Health Care and Philosophy, 4, 79-84.

Colardyn, D. (Ed.). (2002). Lifelong Learning: which ways forward? Utrecht, the Netherlands: LEMMA.

Coulehan, J., \& Williams, P. C. (2003). Conflicting Professional Values in Medical Education. Cambridge Quarterly of Healthcare Ethics, 12, 17-20. 
Cutcliffe, J. R., \& McKenna, P. (1999). Establishing the credibility of qualitative research findings: the plot thickens. Journal of Advanced Nursing, 30(2), 374-380.

Denzin, N. K., \& Lincoln, Y. S. (Eds.). (2003). Collecting and Interpreting Qualitative Materials (second edition ed.). Thousand Oaks: Sage Publications.

Dochy, F., Heylen, L., \& van de Mosselaer, H. (2002). Assessment in het onderwijs: nieuwe toetsvormen en examinering in studentgericht onderwijs en competentiegericht onderwijs (Assessment in education: New assessments and examinination in student-centred education, and competencebased education). Utrecht: Lemma.

Dworkin, G. (1971). Paternalism. In Wasserstrom (Ed.), Morality and the law (pp. 107-126). Belmond: Wadsworth.

Elwyn, G. (2001). Shared decision making: Patient involvement in clinical practice, Dissertation. Nijmegen: Katholieke Universiteit Nijmegen.

Eraut M. (1994). Developing Knowledge and Competence. London: Falmer.

Gastmans, C., \& Dierckx de Casterlé, B. (Eds.) (2000). Verpleegkundige excellentie: Verpleegkunde tussen praktijk en ethiek (Nursing excellence: Nursing in between practice and ethics). Maarssen: Elsevier Gezondheidszorg.

Gastmans, C., \& Vanlaere, L. (2003). Verpleegkundige ethiek: Een onderscheiden domein binnen de ethiek van de gezondheidszorg (An ethic of nursing: a distincted area within health care ethics). Tijdschrift voor Gezondheid en Ethiek, 13(3), 66-70.

Gates. (1994). Advocacy: A nurses' guide. London: Scutari Press.

Glaser, B.G. (1978). Theoretical Sensitivity. Mill Valley, CA: Sociology Press.

Goudriaan, G., \& Vaalburg, A. M. (1998). De vraag als maat (Using demand as a yardstick). Utrecht: Nederlandse Patienten/Consumentenfederatie (NP/CF) and Nederlands Instituut voor Zorg en Welzijn (NIZW).

Grol, R. and Wensing, M. (Eds.) (2001) Implementatie: Effectieve verandering in de patiëntenzorg, Elsevier gezondheidszorg, Maarssen.

Hope, T. (1999). Emperical medical ethics. Journal of Medical Ethics, 25, 219-220.

Houtepen, R., \& Smits, M. J. (1993). Ontwikkelingen in de verpleegkundige ethiek: van regelethiek naar zorgethiek? (Developments in nursing ethics: from a principles approach towards an ethic aof care?) Wijsgerig Perspectief, 34(5), 162-167.

Ingelfinger, F. J. (1985). Arrogance. New England Journal of Medicine, 203, 1507-1511.

Jansen, M. G. M. J. (2005). Presentie en Prestatie. Sleutelbegrippen in de verpleegethiek (Presence and performance. Key concepts in nursing ethics). Dissertation. Universiteit voor Humanistiek, Utrecht.

Kessels, J. W. M. (1993). Towards Design Standards for Curriculum Consistency in Corporate Education. Thesis. Twente University, Enschede, the Netherlands.

Kessels, J. (2004). Nawoord bij 'Het ontwerp van een leertraject in samenspraak' (Epilogue to: The design of an educational programme). Onderwijs en Gezondheidszorg, 6, 20-21.

Kessels, J., \& Plomp, G. (1999). A systematic and relational approach to obtaining curriculum consistency in corporate education. Journal of Curriculum Studies, 31(6), 679-709.

Lincoln, Y., \& Guba, E. G. (1985). Naturalistic inquiry. Newbury Park CA: Sage. 
Little, M. (1998). Care: from theory to orientation and back. Journal of Medicine and Philosophy, 23(2), 190-209.

Little, P., Everitt, H., Williamson, I., Warner, G., Moore, M., Gould, C., et al. (2001). Preferences of patients for patient centred approach to consultation in primary care: oberservational study. British Medical Journal, 322, 468-472.

May, C. (1990). Research on nurse-patient relationships:problems, of theory, problems of practice. Journal of Advanced Nursing(15), 307-315.

Mead, N., \& Bower, P. (2000). Measuring patient-centredness: a comparison of three observation-based instruments. Patient Education and Counseling, 39, 71-80.

McCormack, B. (2004). Person-centredness in gerontological nursing: an overview of the literature. Journal of Clinical Nursing, 13(3a), 31-38.

Moody, H. R. (1992). Ethics in an aging society. Baltimore/London: John Hopkins University Press.

O'Neill, O. (2002). Autonomy and Trust in Bioethics. Cambridge: Cambridge University Press.

Onstenk, J. (1997). Lerend leren werken. Brede vakbekwaamheid en integratie van leren, werken en innoveren (Learning while learning to work. Broad competencies and integration of learning, working, and innovation). Delft: Eburon

Philipsen, H. (1997). Vraaggestuurde zorg: Het belang van professionele fundering van de 'erkende vraag' naar zorg (Demand-oriented care: the importance of a professional foundation of 'a recognized demand' for care. In L. Boon (Ed.), Vraaggestuurde Zorg. Amstelveen: Sympoz.

Polit, F., \& Hungler, B. P. (1995). Nursing Research: principles and methods. Philadelphia: J.P.Lippincott Company.

Pool, A., Mostert, H., \& Schumacher, J. (2003). De kunst van het afstemmen (The art of finetuning). Utrecht: NIZW.

Pope, C., \& Mays, N. (1995). Reaching the parts other methods cannot reach:an introduction to qualitative methods in health and health services research. BMJ, 311, 42-45.

Proot, I. M., Crebolder, H. F. J. M., Huijer Abu Saad, H., \& ter Meulen, R. H. J. (1998). Autonomy in the rehabilitation of stroke patients in nursing homes. A concept analysis. Scandinavian Journal of Caring Sciences, 12, 139-145.

Proot, I., Huijer Abu Saad, H., de Esch-Janssen, W. P., Crebolder, H. F. J. M., \& ter Meulen, R. H.J. (2000). Patient autonomy during rehabilitation: the experiences of stroke patients in nursing homes. International Journal of Nursing Studies, 37, 267-276.

RVZ. (1998). Naar een meer vraaggerichte zorg (Towards increased demand-orientedness). Zoetermeer, the Netherlands: Raad voor de Volksgezondheid.

Schön, D. A. (1987). Educating the reflective practitioner. San Francisco: Jossey-Bass.

Senge, P. M. (1992). The fifth Discipline: The art $\&$ Practice of the Learning Organization. Milson Point, New South Wales: Random House Australia.

Smits, M. J. (1996). Ethiek van de verpleegkundige praktijk: Zorgethiek en regelethiek? (Ethics of nursing practice: An ethic of care or a principles approach?) Verpleegkunde, 12(1), 27-36. 
Smits, M. J. (2004). Zorgen voor een draaglijk bestaan: Morele ervaringen van verpleegkundigen (Taking care of a bearable existence. Moral experiences of nurses). Dissertation. Amsterdam: Aksant.

Stewart, M. (2001). Towards a global definition of patient centred care. British Medical Journal (322), 444-445.

Strauss, A. L., \& Corbin, J. (1998). Basics of Qualitative Research. Techniques and Procedures for Developing Grounded Theory. Thousand Oaks: Sage Publications.

Terpstra, E. (1997). Beleidsmatige dilemma's bij de vormgeving van vraaggestuurde zorg (Dilemmas in policy with respect to demand-led care). In L. Boon (Ed.), Vraaggestuurde zorg (pp. 7-13). Amstelveen: Stichting Sympoz.

Tillema, H. (1997). Inzicht in competentie-ontwikkeling: Ervaringen met de invoering van performance-assessment intstrumenten in organisaties (Insight into competence development: Experiences with implementing performance asessment instruments in organizations). Opleiding en Ontwikkeling(6), 21-24.

Ten Have, H.A.M.J., ter Meulen, R.H.J., van Leeuwen,E. (2003). Medische Ethiek (Medical Ethics), Bohn, Stafleu, van Loghum, Houten.

Ter Meulen, R. H. J. (2002). Towards a social concept of the person. In D. C. Thomasma, D. N. Weisstub \& C. Hervé (Eds.), Series International Library of Ethics, Law and the New Medicine (Vol. 7, pp. 129-135). Dordrecht: Kluwer Academic Publishers.

Tonkens, E. (2003). Mondige burgers, getemde professionals. Marktwerking, vraagsturing en professionaliteit in de publieke sector (Empowering citizens and taming professionals: the market, demand-driven care and professionalism in the public sector). Utrecht: NIZW.

Tronto, J. C. (1994). Moral boundaries: a political argument for an ethic of care. New York: Routledge.

Van Delden, H., van der Scheer, L., van Thiel, G., \& Widdershoven, G. (2005). Ethiek en Empirie. Theorie en methodologie van empirisch ethisch onderzoek (Ethics and empirics. Theory and methodology of empirical ethical research). Maastricht: Océ Business Services.

Van der Arend, A. (2003). De Verpleegkundige als 'patient advocate' (The nurse as 'patient advocate'). Tijdschrift voor Gezondheid en Ethiek, 13(3), 71-74.

Van der Arend, A., \& Gastmans, C. (2002). Ethisch zorg verlenen. Handboek voor de verpleekundige beroepen (Giving ethical care: Handbook for nursing professionas). Baarn: HBuitgevers.

Van der Arend, A., \& Remmers-van den Hurk, C. H. (1999). Moral problems among Dutch nurses: a survey. Nursing Ethics, 6(6), 468-482.

Van der Kraan, W. G. M. (2001). Vraaggericht en vraaggestuurd: Een literatuuronderzoek naar vraaggerichtheid en vraagsturing in de gezondheidszorg (Demand-oriented and demand-driven. A review of the literature into demand-oriented and demand-driven care in the health-care sector). The Hague: ZONMw en Erasmus Universiteit Rotterdam.

Van der Lyke, S., \& Proot, I. (2004). Kwalitatief onderzoek: over stromingen, kwaliteit en praktische relevantie (Qualitative research : trends, quality and practical relevance). In K. Cox, D. de Louw, J. Verhoef \& C. Kuiper (Eds.), Evidence-Based Practice voor Verpleegkundigen (pp. 81-100). Utrecht: Lemma.

Van Eekelen, I. (2005). De wil om te leren (Readiness to learn). Leren in ontwikkeling, 11(5). 
Verkerk, M. (2003). Zorgethiek: naar een geografie van mogelijkheden (An ethic of care: towards a geography of possibilities). In H. Manschot \& H. van Dartel (Eds.), in gesprek over goede zorg (pp. 177-190). Amsterdam: Boom.

Verkerk, M., De Bree, M., \& Jaspers, F. (2004). Visies op professioneel gedrag: Meer nadruk leggen op reflectie en verantwoording (Perspectives on professional behaviour: Emphasizing reflection and accounting for care). Medisch Contact, 59(51), 235-2037.

Vulto, M. E. (2002). Welzijn en waardigheid voor langdurige zorggebruikers(Wellness and dignity for longterm users of care). Leiden: STG.

Widdershoven, G. (1998). Autonomie in de hulpverlening (Autonomy in professional assistance). Tijdschrift voor de Sociale Sector (januari/februari), 20-25.

Widdershoven, G. (2000). Ethiek in de kliniek(Ethics in the clinic): Amsterdam:Boom. 
SUMMARY/ SAMENVATTING 


\section{SUMMARY}

This thesis concerns a research project into client-centred care. Client-centred care is considered in this thesis as an umbrella concept, encompassing several care concepts such as demand-oriented care, emotion-oriented care and demand-led care. The context is the primary process of home care delivered by nurses and auxiliary nurses (subsequently called nurses) to chronically ill clients. Several reports have highlighted the need for development of competencies in professionals with respect to client-centred care. What client-centred care in the context of the primary process of home care for chronically ill clients encompasses, however, is not completely clear. Confusion exists about both the meaning and the application of client-centred care, which is to the detriment of the successful introduction of client-centred care in practice.

This thesis consists of three parts. Part I (chapters 2-4) explores and describes the visions of clients and nurses on client-centred care and on competencies required in nurses for client-centred care. Part II (chapter 5) concerns the development of a learning programme aimed at development of competencies for client-centred care in nurses. In part III (chapters 6-8) the impact of the learning programme is evaluated, on the learning processes of the nurses, on competencies in nurses and on client-centredness perceived by the client. Moreover, enabling and constraining factors with respect to the implementation of client-centred care are discussed. This part also includes the development and testing of the measurement instruments applied in the evaluation study.

Chapter 1 of this thesis describes the background and relevance of the project. Since the 1980s, in the Netherlands, a wholesale change can be observed in the perspective on care. The provider-oriented approach that dominated until then increasingly came to be judged as patronizing and paternalistic. This is partly connected to individualization in society and increased self-assertiveness among clients. Moreover, a provider-oriented approach is considered too expensive, inefficient, bureaucratic, and maladapted to the aging of the population and the expected increase of the numbers of chronically ill people. Client-centred care covers a variety of care concepts, in which the client perspective and client autonomy are central. Several of these concepts are described in chapter 1 in line with the following dimensions: central perspective, goals, roles and responsibilities, decision making and the context of the situation in which the concept is used. In the Netherlands, the concepts 'vraaggerichte zorg' (literally translated as 'demand-oriented care') and 'vraaggestuurde zorg' (literally translated as 'demand-led care' or 'demand-driven care') are frequently used. In English literature, however, these concepts are mainly used on a social-political level. The 
emphasis on the client demand is estimated to have an additional economic advantage by means of efficiency.

It is particularly the chronically ill who set value on client-centred care, because many of them are dependent on professional care for a long time. Many of them are well informed about their illness and want to participate in care decisions, because a chronic illness may affect a person's total existence as well as the existence of his or her family members.

Development of competencies in nurses with respect to client-centred care is discussed as a didactical approach. The theoretical framework is grounded in a trend called social-constructivism. Development of competencies emphasizes the student's learning process in practice. This approach offers possibilities to meet the changing requirements imposed on nurses.

Chapter 2 concerns the perspective of expert clients and family caregivers on client-centred care and on nurses' competencies. Based upon two focus group interviews each with seven participants, the core category 'recognition' has been identified and developed. Client-centred care entails recognition by the professional of the client's values. Recognition concerns the client's and family caregiver's feeling that his or her demand has been heard and is respected. Clientcentred care means an attitude of the professional entailing recognition of the client's values. Client values of interest with respect to the demand are:

- uniqueness (attention for and understanding the client as an individual human being with his/her own life story, beliefs, cultural background and boundaries),

- comprehensiveness (to be seen as an integral human being, part of a family system),

- continuity of life (having the opportunity to continue ones life, including one's habits),

- fairness (having the right to ask for care needed; also less competent and less self-assertive clients should get the care they need),

- autonomy (having the possibility to be who you are, and self-determination).

Values that turn out to be of interest with respect to the care-relationship are:

- equality (experience- based knowledge is just as valuable and necessary as professional knowledge),

- partnership (being accountable, active, committed and collaborating partners in care),

- interdependence (mutual receptiveness, understanding, trust, acceptance and respect for boundaries).

Dialogue is seen as the optimal interaction pattern for recognition of client values. Nurse's competencies identified with respect to recognition of client values in a dialogue are: attentiveness (ongoing attention to know and understand the client, 
his/her values, needs and wishes); responsiveness (active, committed and responsible care that meets client values); being a critical partner in care (giving and grounding a professional opinion and discussing personal, professional and organizational boundaries); and being a developer of the client's competencies (facilitating and motivating the client to participate in the care process).

Chapter 3 concerns a second study into the client perspective among 45 clients receiving home care, by means of participatory observations and semi-structured interviews. This study makes clear that clients differ with respect to desired participation in the care process. Client-centred care emerges as congruence between participation desired by the client and participation allowed by the nurse. Based upon this study, six patterns of interaction were distinguished: toeing the line (participation is not as desired by the client; the client avoids confrontation), reluctance (avoidance of care offered by the nurse), consent (adhering to the opinion and advice of the nurse), dialogue (interactive process between equal, interdependent partners), consuming (active, responsible and self assertive client directs care desired), and fighting (no participation as desired by the client; clients seek confrontation). Clients experience congruence with consent, dialogue and consuming. No congruence is experienced with toeing the line, reluctance and fighting. Several factors appear to influence desired participation by the client, such as client competencies, energy available, personality, preferences, beliefs on care, the nature of the demand, coping processes, age, and care experiences in the past. The findings also make clear that differences exist among nurses with respect to client participation allowed. These differences appeared to be closely related to client competencies to participate in care as estimated by the nurse. Furthermore, allowed participation by nurses was found to be related to the competencies of the nurses (as identified in chapter 2), the nurse's beliefs concerning the nurse's role and the role of the client, and impediments in the work environment (e.g. presence of protocols, a heavy workload, central planning of work processes, and a task-oriented organization).

Chapter 4 concerns the nurse's perspective towards client-centred care. In a study among ten nurses and auxiliary nurses, the core category 'competing responsibilities' has been identified and developed through participatory observations and semi-structured interviews. Offering client-centred care and being a responsive professional appears to be not that simple. Nurses experience several conflicting roles and responsibilities: as a critical professional (e.g. evidence-based practice, and anticipating long-term problems), a developer of client competencies (e.g. promoting independence, stimulating clients who are not motivated for care), as an individual (e.g. protecting own privacy) and an employee of the care organization (e.g. production and efficiency). Strategies identified in balancing 
between these competing responsibilities are: pleasing (doing as the client asks; conflicting responsibilities are avoided), dialoguing (actively dealing with competing responsibilities in dialogue with the client), directing (acting in a dominant way, responsibilities as a professional are central), and detaching (the emphasis is on executing the task). Two strategies were also used as second-choice strategies. This means that the strategy chosen in general was not the primary preference of the nurse in question: directing as second choice (soft paternalism due to impaired client competencies) and detaching as second choice (orientation to the task due to organizational barriers). It is concluded that effectively balancing between competing responsibilities is seen in the strategies 'dialoguing' and 'directing as second choice'. These nurses experienced work satisfaction. In these strategies both the conditions 'awareness of the competing responsibilities' and 'active responsibility taking for competing responsibilities' are present. The study offers more insight into individual learning needs in nurses.

Chapter 5 reports on the development of a learning programme aimed at development of competencies in nurses with respect to client-centred care. Kessels's Eight-fields model guided the development of the learning programme. Clientcentred care, client outcomes and nurse competencies were defined in collaboration with a steering committee of central stakeholders, and validated by a broad advisory board. The findings of Part I served as input in this process. Clientcentred care was called 'demand-oriented care' by the stakeholders involved. It was defined as:

- Care that arises from individual preferences and demands of the client, that is accomplished in a dialogue with the nurse, and in which the client has the final say.

Client outcomes were defined as:

- Feelings expressed by the client of being respected and taken seriously by the caregiver, and of autonomy in the way care decisions are made.

Nurse competencies required concern:

- a care process in dialogue with the client,

- enabling client participation, and

- dealing with tensions.

A social constructivist perspective on learning and on the principles of competency-based education was integrated in the learning activities chosen, such as the emphasis on the nurse's experiences in practice, reflection, self-assessment, 
implementation and transfer of knowledge, attitude and skills in practice. The entire programme 'Care in Dialogue' consisted of a basic module and an advanced module. The basic module (two half-days) was meant for all employees in the care organization (25-40 persons per meeting). It focused on awareness of wishes and demands of clients and on barriers in the actual situation. The advanced module (seven half-days) was meant for nurses and auxiliary nurses working in the primary process of care (10-12 per group) who had attended the basic module. In the first sessions the emphasis was on attitude development and communication, using role plays, feedback and discussions. The final two sessions were follow-up sessions in which critical ethical reflection, accounting for priorities set and self-assertiveness were central by means of presentations of best practices. Expert clients and family caregivers played an important role in the programme with respect to awareness of the client perspective, of their attitude towards the client and its underlying moral values. In connection to the learning programme, the nurse competencies identified and the client outcomes were operationalized into two measurement instruments: the 'Care in dialogue Competency Scale' and the 'Client-Centred Care Questionnaire' (CCCQ).

Chapter 6 describes how the 'Care in dialogue Competency Scale' was developed and tested. The instrument is a self-assessment instrument aimed at measuring competencies for client-centred care. This instrument has been developed for nurses and auxiliairy nurses giving home care to chronically ill clients. It consists of three scales, one for each of the three competencies as defined. The scales were tested with 74 nurses and auxiliary nurses of four home care organizations. The internal consistency of the scales was studied by using principal components analysis and by calculating Cronbach's alpha. Seven items of the initial instrument were removed. The total (adapted) instrument consists of 29 items (14 items competency 'care process in dialogue'; 7 items competency 'enabling client participation'; 8 items competency 'dealing with tensions'). The construct validity, internal consistency and feasibility seem acceptable. The instrument contributes to awareness of competencies required for client-centred care and offers possibilities for evaluation and critical reflection.

Chapter 7 explains how the 'Client-Centred Care Questionnaire' (CCCQ) was developed and tested. The CCCQ is a short and relatively simple tool that can be used to evaluate how clients perceive the client-centredness of home care. This instrument consists of 15 items, which are an operationalization of the client values as identified in chapter 2 and of the client goals as identified in chapter 5 . It can be used to evaluate effects of interventions aimed at improving client-centred care from a client perspective. Evaluation of client-centred care from a client perspective is increasingly important, and this questionnaire allows home care 
organizations to evaluate their care. The responses of clients give indications for improving client-centred care.

Chapter 8 describes how the impact of the learning programme has been evaluated at three levels, guided by Kessels's Eight-fields model: learning processes, performance of competencies and client-centred care as perceived by the client. Three home-care organizations were involved in the evaluation study. In total 175 employees participated in the basic module, 34 nurses and auxiliary nurses participated in the advanced module. In total 107 chronically ill clients were involved in the study. Findings indicate a positive impact on two of the evaluation levels: the learning processes and the performance of competencies in practice. No statistically significant impact was found on clients two months after the end of the programme. The process evaluation reveals that nurses experienced barriers in performing client-centred care that could not be removed exclusively by the nurses' actions. Moreover, the influence of trained nurses on collegues and managers appeared to be limited. It is expected that the impact of the programme on clients will become visible if more nurses participate in the learning programme, and if the implementation will be supported by policy, structures and processes at all levels of the care organization. The process evaluation provides knowledge concerning preconditions for learning processes and performance of competencies in practice. Constraining factors for the learning process are lack of time and a lower education level. Constraining factors for performance in practice are central planning, a task-oriented nurse system, too heavy a workload, and lack of support from colleagues and managers. Facilitating factors are feedback from expert clients and family caregivers, critical reflection, discussions and moral deliberation, support from an implementation group installed for this purpose within the care organization, time and support from colleagues and from the managers.

Chapter 9 discusses the results of the study as well as some theoretical, ethical, methodological reflections. The present study offers more insight into perspectives on client-centred care and into learning how to balance in between. Clientcentred care emerges from the present study as a complex, contextual and relational process in which the nurse and the client participate in a unique way. Three patterns were distinguished in the present study as client-centred care: consuming, a dialogue and consent. The umbrella-concept of 'client-centred care' has been chosen, because it encompasses all three patterns. The dialogue is close to the concept of demand-oriented care. Consuming is close to the concept of demand-led care. Consent is closely related to soft paternalism. Competencies required in nurses to find an effective balance between competing roles and responsibilities are close to the concept of professionalism. The present stuy offers 
more insight into competencies required in nurses and into factors related to the development and performance of these competencies.

The findings of the present study emphasize the ethical understanding of clientcentred care. The findings are discussed with respect to four main streams in ethics: the principles approach, an ethic of care, phenomenological ethics, and nursing ethics. The liberal approach to autonomy (autonomy as negative freedom, characterized by self-determination and freedom from intervention by a third person), and a phenomenological approach (autonomy as positive freedom, characterized by autonomy as identification) are complementary. Both approaches provide insight and guidance in helping the client to realize his or her autonomy. To understand the dynamic character of the individual client's needs in context, however, the phenomenological approach is indispensable. An ethic of care and nursing ethics have a valuable contribution to make towards the thinking about the care relationship with the client that is required in the context of everyday care.

Strengths of the qualitative studies are the involvement of clients, the design chosen, leading to concept development that fit into practice, triangulation of methods, and peer review. Given the systematic and purposeful selection of situations and participants aimed at obtaining a good representation of the population under study, and the accurate description of the characteristics and context, the explanatory power and transferability of the findings seem acceptable to good. Variation was somewhat limited with respect to gender and education level. Additional research is required with respect tot the theoretical concepts developed and the relationships between the concepts.

Strengths of the programme developed are the internal and external consistency, partly because of the clients involved. A limitation of the programme was the restriction of the promotion of client-centred care to development of competencies in nurses. A constraining factor was the tension between the time needed for proper analysis of qualitative data on the one hand, and the pressure of time with respect to the development of the learning programme on the other.

Strengths of the quantitative part of the study were the multi-level evaluation, the content validity of the measurement instruments developed, and the formulation of the items in the competency scale in terms of behaviour. The quantitative studies were limited due to the small sample sizes, absence of a control group and the absence of repetitive testing. In general, it can be concluded that, although the studies presented in this part are not robust enough to allow firm generalizations, the first results are promising.

The thesis ends with some recommendations. For clinical practice, a relational and a contextual approach are recommended. In a relational approach, the care process is shaped in the care relationship with the client. In a contextual approach, 
the nurse allows participation desired by the client, provided his or her competencies to participate in care and taking into account remaining roles and responsibilities. Feedback, critical reflection and moral deliberation with colleagues are of vital importance.

With respect to the education of nurses, it is recommended to develop the competencies 'care process in dialogue', 'enabling client participation' and 'dealing with tensions' in nurses. Development of competencies should be tailored to the individual nurse's learning demands. Policy-makers are recommended to avoid confusion regarding the concept of client-centred care and related care concepts, by clarifying the core perspective, central level and central aspects of client-centred care. It is recommended to enhance awareness in all employees of the care organization with respect to the central position of the client and of the client demand by communicating experiences, expectations and best practices on a regular basis. Managers should promote client-centred care in the primary process by enhancing professional autonomy in taking care decisions and by supporting nurses with respect to care decisions in a particular context. Client-centred care in the primary process should be embedded in policy, structures and processes of the persons involved in all levels in the care organization. Policy-makers are recommended to recognize that clients differ with respect to desired participation in care.

Further research with respect to the theoretical concepts developed and the relationships between the concepts is recommended. It is also recommended to further investigate the impact of client-centred care on clients and nurses, and the relationship with background variables such as education level of nurses. Further investigation is warranted into the reliability, validity and responsiveness of the instruments developed. The perspectives on client-centred care of clients and nurses in the acute care setting deserve attention. Research into development of moral values in nurses and the development of normative guidelines for nurses might sustain professionals in their approach of client-centred care. Further research into additional interventions aimed at the implementation of clientcentred care is recommended. 
Dit proefschrift betreft een onderzoek naar cliëntgecentreerde zorg. Cliëntgecentreerde zorg wordt in dit proefschrift beschouwd als een overkoepelend begrip dat diverse zorgconcepten, zoals vraaggerichte zorg, belevingsgerichte zorg en vraaggestuurde zorg omvat. De context is het primaire proces van thuiszorg door verpleegkundigen en verzorgenden (verder genoemd verplegenden) aan chronisch zieken. Diverse rapporten wijzen op de noodzaak van competentieontwikkeling van professionals met betrekking tot cliëntgecentreerde zorg. Echter, wat cliëntgecentreerde zorg concreet inhoudt in het primaire proces van thuiszorg voor chronisch zieke cliënten is niet geheel duidelijk. Er bestaat verwarring over de betekenis en de toepassing van cliëntgecentreerde zorg, hetgeen een succesvolle invoering van cliëntgecentreerde zorg in de praktijk in de weg staat.

Dit proefschrift bestaat uit drie delen. Deel I (hoofdstuk 2-4) onderzoekt en beschrijft de visie van cliënten en van verplegenden op cliëntgecentreerde zorg en op noodzakelijke competenties van verplegenden voor cliëntgecentreerde zorg. Deel II (hoofdstuk 5) betreft de ontwikkeling van een leertraject om competenties voor cliëntgecentreerde zorg bij verplegenden te ontwikkelen. In deel III (hoofdstuk 6-8) wordt de impact van het leertraject op het leerproces van verplegenden, op de competenties van verplegenden en op de door de cliënt ervaren cliëntgecentreerdheid geëvalueerd. Daarnaast worden bevorderende en belemmerende factoren ten aanzien van de implementatie van cliëntgecentreerde zorg aan de orde gesteld. Dit deel omvat eveneens de ontwikkeling en het testen van de meetinstrumenten die bij het evaluatieonderzoek gebruikt werden.

Hoofdstuk 1 van dit proefschrift beschrijft de achtergrond en relevantie van het project. In Nederland kan sinds 1980 een kanteling worden waargenomen in de visie op zorg. De aanbodgestuurde benadering die tot dan toe overheerst wordt in toenemende mate als betuttelend en paternalistisch beoordeeld. Dit hangt onder andere samen met de individualisering van de maatschappij en de toegenomen mondigheid van de cliënt. Daarnaast wordt een aanbodgestuurde benadering beschouwd als te duur en als inefficiënt, bureaucratisch en onvoldoende aangepast aan de toenemende vergrijzing en de verwachte toename van het aantal chronisch zieken. Cliëntgecentreerde zorg omvat een variatie aan zorgconcepten waarin het cliëntenperspectief en autonomie van de cliënt centraal staan. Diverse van deze zorgconcepten worden beschreven in hoofdstuk 1 aan de hand van de dimensies: centraal perspectief, doel, rollen en verantwoordelijkheden, besluitvorming en context van de situatie waarin het concept wordt gebruikt. In Neder- 
land worden de concepten 'vraaggerichte zorg' (letterlijk vertaald als 'demandoriented care') en 'vraaggestuurde zorg' (letterlijk vertaald als 'demand-led care' of 'demand-driven care') veelvuldig gebruikt. In de Engelstalige literatuur, echter, worden deze concepten voornamelijk op sociaal-politiek niveau gebruikt. Van de nadruk op de vraag van de cliënt wordt een bijkomend economisch voordeel verwacht in de vorm van efficiency.

Met name chronisch zieken hechten waarde aan cliëntgecentreerde zorg omdat velen van hen voor lange tijd afhankelijk zijn van professionele zorg. Velen van hen zijn goed geïnformeerd over hun ziekte en willen deelnemen aan besluiten over zorg, omdat een chronische ziekte van invloed kan zijn op het totale bestaan van de persoon en ook op het bestaan van familieleden.

Competentieontwikkeling van verplegenden met betrekking tot cliëntgecentreerde zorg wordt besproken als een didactische benadering. Het theoretisch kader is gebaseerd op een stroming genaamd 'sociaal constructivisme'. Competentieontwikkeling benadrukt het leerproces van de student in de praktijk. Deze benadering biedt mogelijkheden om tegemoet te komen aan de veranderende eisen die worden gesteld aan verplegenden.

Hoofdstuk 2 betreft het perspectief van ervaringsdeskundige cliënten en mantelzorgers op cliëntgecentreerde zorg en op competenties van verplegenden. Op basis van twee focusgroep interviews met ieder zeven participanten werd het kernbegrip 'erkenning' geïdentificeerd en ontwikkeld. Bij cliëntgecentreerde zorg gaat het om erkenning van de waarden van de cliënt door de professional. Erkenning betreft het gevoel bij de cliënt en zijn naaste dat zijn/ haar waarden door de professional gehoord en gerespecteerd wordt. Waarden die ten aanzien van de vraag van belang blijken zijn:

- uniciteit (aandacht en begrip voor de cliënt als individu met zijn/haar eigen levensverhaal, opvattingen, culturele achtergrond en grenzen),

- totaliteit (gezien worden als een integraal individu, deel uitmakend van een gezinssysteem),

- continuïteit van leven (de mogelijkheid hebben om zijn/haar eigen leven voort te zetten, inclusief iemands gewoonten),

- rechtvaardigheid (het recht hebben om noodzakelijke zorg te vragen; ook minder competente en minder assertieve cliënten dienen de zorg die zij nodig hebben te krijgen),

- autonomie (de mogelijkheid hebben om jezelf te zijn, en zelfbeschikking).

Waarden van de cliënt ten aanzien van de zorgrelatie die van belang blijken zijn:

- gelijkwaardigheid (ervaringskennis is even waardevol en noodzakelijk als professionele kennis),

- partnerschap (verantwoordelijke, actieve, betrokken en samenwerkende partners in de zorg zijn) 
- onderlinge afhankelijkheid (wederzijdse ontvankelijkheid, begrip, vertrouwen, acceptatie en respect voor grenzen).

De dialoog wordt gezien als het optimale interactiepatroon voor erkenning van waarden van de cliënt. Geïdentificeerde competenties voor verplegenden met betrekking tot erkenning van de waarden van de cliënt in dialoog zijn: attentiviteit (voortdurende oplettendheid gericht op het kennen en begrijpen van de cliënt, zijn/ haar waarden, behoeften en wensen); responsiviteit (actieve, betrokken en verantwoordelijke zorg die tegemoet komt aan de waarden van de cliënt); een kritische zorgverlener zijn (geven en onderbouwen van een professionele mening en bespreken van professionele, persoonlijke en organisationele grenzen) en ontwikkelaar zijn van de competenties van de cliënt (faciliteren en motiveren van de cliënt om te participeren in het zorgproces).

Hoofdstuk 3 beschrijft een tweede onderzoek naar het clientenperspectief bij 45 cliënten die thuiszorg ontvingen, met behulp van participerende observaties en semi-gestructureerde interviews. Dit onderzoek maakt duidelijk dat cliënten verschillen wat betreft de gewenste participatie in het zorgproces. Cliëntgecentreerde zorg komt naar voren als congruentie tussen door de cliënt gewenste participatie en de door de verpleegkundige mogelijk gemaakte participatie. Op basis van dit onderzoek werden zes patronen van interactie onderscheiden: aanpassen (participatie is niet zoals gewenst door de cliënt; de cliënt vermijdt confrontatie), afhouden (ontwijken van verplegende zorg), instemmen (volgen van de mening en adviezen van de verplegende), dialoog (interactief proces tussen gelijkwaardige, onderling afhankelijke partners), consumeren (een actieve, verantwoordelijke en assertieve cliënt stuurt de zorg die hij/zij wil), en strijden (participatie is niet zoals gewenst door de cliënt; the cliënt zoekt de confrontatie). Cliënten ervaren congruentie bij de patronen instemmen, dialoog en consumeren. Er is geen congruentie bij aanpassen, afhouden en strijden. Diverse factoren blijken de door de cliënt gewenste participatie te beïnvloeden, zoals de competenties van de cliënt, beschikbare energie, persoonlijkheid, voorkeur, opvattingen over zorg, de aard van de vraag, copingprocessen, leeftijd en ervaringen in het verleden met zorg. De bevindingen maken ook duidelijk dat verplegenden verschillen wat betreft het mogelijk maken van participatie door de cliënt. Deze verschillen bleken nauw samen te hangen met de door de verplegende ingeschatte competenties van de betrokken cliënt om te participeren in de zorg. Het mogelijk maken van participatie werd tevens beïnvloed door de eerder genoemde competenties van de verpleegkundige (zie hoofdstuk 2), opvattingen over de eigen rol en over de rol van de cliënt en barrières in de werkomgeving (protocollen, hoge werkdruk, centrale planning van werkprocessen en een taakgerichte organisatie). 
Hoofdstuk 4 betreft het perspectief van verplegenden op cliëntgecentreerde zorg. In een studie onder tien verpleegkundigen en verzorgenden, met behulp van participerende observaties en semi-gestructureerde interviews, werd het kernbegrip 'conflicterende verantwoordelijkheden' geïdentificeerd en ontwikkeld. Het blijkt niet zo eenvoudig om cliëntgecentreerde zorg te bieden en een responsieve professional te zijn. Verplegenden ervaren diverse hiermee conflicterende rollen en verantwoordelijkheden: als kritische professional (bijv. evidencebased practice en anticiperen op lange termijn problemen), ontwikkelaar van competenties van de cliënt (bijv. bevorderen van onafhankelijkheid, stimuleren van cliënten die niet gemotiveerd zijn voor zorg), individu (bijv. bescherming eigen privacy) en als werknemer van de zorgorganisatie (bijv. productie en efficiency). Geïdentificeerde strategieën bij het balanceren tussen deze conflicterende verantwoordelijkheden zijn: behagen (doen wat de cliënt vraagt; hiermee conflicterende verantwoordelijkheden vermeden), dialoog (actief oppakken van conflicterende verantwoordelijkheden in overleg met de cliënt), sturen (dominant handelen; de professionele verantwoordelijkheid staat centraal) en zich distantiëren (nadruk op de uitvoering van de taak). Twee strategieën werden ook als tweede keus strategieën gehanteerd. Dit wil zeggen dat de gehanteerde strategie over het algemeen niet de voorkeur had van de betreffende verpleegkundige: sturen als tweede keus (gematigd paternalisme ten gevolge van verminderde competenties van de cliënt) en zich distantiëren als tweede keus (zich richten op de taak ten gevolge van organisatorische barrières). Geconcludeerd wordt dat er bij de strategieën 'dialoog' en 'sturen als tweede keus' sprake is van effectief balanceren tussen conflicterende verantwoordelijkheden. Deze verplegenden ervoeren tevredenheid in hun werk. Bij deze strategieën zijn de condities 'zich bewust zijn van de conflicterende verantwoordelijkheden' en 'actief verantwoording nemen hiervoor' aanwezig. De bevindingen geven meer inzicht in individuele leerbehoeften van verplegenden.

Hoofdstuk 5 betreft de ontwikkeling van een leertraject gericht op competentie ontwikkeling van verplegenden voor cliëntgecentreerde zorg. Het 'Acht-velden model' van Kessels stroomlijnde de ontwikkeling van het leertraject. Cliëntgecentreerde zorg, cliëntdoelen en competenties van verplegenden werden vastgesteld in samenwerking met een stuurgroep van centrale belanghebbenden en gevalideerd door een brede klankbordgroep. De bevindingen van deel I dienden als input in dit proces.

Cliëntgecentreerde zorg werd door de betrokken belanghebbenden 'vraaggerichte zorg' genoemd. Dit werd gedefinieerd als:

- Zorg die uitgaat van de wensen en ervaren behoeften van de zorgvrager, die in dialoog tot stand komt en waarbij de zorgvrager uiteindelijk beslist. 
- onderlinge afhankelijkheid (wederzijdse ontvankelijkheid, begrip, vertrouwen, acceptatie en respect voor grenzen).

De dialoog wordt gezien als het optimale interactiepatroon voor erkenning van waarden van de cliënt. Geïdentificeerde competenties voor verplegenden met betrekking tot erkenning van de waarden van de cliënt in dialoog zijn: attentiviteit (voortdurende oplettendheid gericht op het kennen en begrijpen van de cliënt, zijn/ haar waarden, behoeften en wensen); responsiviteit (actieve, betrokken en verantwoordelijke zorg die tegemoet komt aan de waarden van de cliënt); een kritische zorgverlener zijn (geven en onderbouwen van een professionele mening en bespreken van professionele, persoonlijke en organisationele grenzen) en ontwikkelaar zijn van de competenties van de cliënt (faciliteren en motiveren van de cliënt om te participeren in het zorgproces).

Hoofdstuk 3 beschrijft een tweede onderzoek naar het clientenperspectief bij 45 cliënten die thuiszorg ontvingen, met behulp van participerende observaties en semi-gestructureerde interviews. Dit onderzoek maakt duidelijk dat cliënten verschillen wat betreft de gewenste participatie in het zorgproces. Cliëntgecentreerde zorg komt naar voren als congruentie tussen door de cliënt gewenste participatie en de door de verpleegkundige mogelijk gemaakte participatie. Op basis van dit onderzoek werden zes patronen van interactie onderscheiden: aanpassen (participatie is niet zoals gewenst door de cliënt; de cliënt vermijdt confrontatie), afhouden (ontwijken van verplegende zorg), instemmen (volgen van de mening en adviezen van de verplegende), dialoog (interactief proces tussen gelijkwaardige, onderling afhankelijke partners), consumeren (een actieve, verantwoordelijke en assertieve cliënt stuurt de zorg die hij/zij wil), en strijden (participatie is niet zoals gewenst door de cliënt; the cliënt zoekt de confrontatie). Cliënten ervaren congruentie bij de patronen instemmen, dialoog en consumeren. Er is geen congruentie bij aanpassen, afhouden en strijden. Diverse factoren blijken de door de cliënt gewenste participatie te beïnvloeden, zoals de competenties van de cliënt, beschikbare energie, persoonlijkheid, voorkeur, opvattingen over zorg, de aard van de vraag, copingprocessen, leeftijd en ervaringen in het verleden met zorg. De bevindingen maken ook duidelijk dat verplegenden verschillen wat betreft het mogelijk maken van participatie door de cliënt. Deze verschillen bleken nauw samen te hangen met de door de verplegende ingeschatte competenties van de betrokken cliënt om te participeren in de zorg. Het mogelijk maken van participatie werd tevens beïnvloed door de eerder genoemde competenties van de verpleegkundige (zie hoofdstuk 2), opvattingen over de eigen rol en over de rol van de cliënt en barrières in de werkomgeving (protocollen, hoge werkdruk, centrale planning van werkprocessen en een taakgerichte organisatie). 
digen en verzorgenden van vier thuiszorgorganisaties. De interne consistentie van de schalen werd onderzocht door principale componenten analyse en door berekening van Cronbach's alfa. Zeven items van het oorspronkelijke instrument werden verwijderd. Het totale (aangepaste) instrument bestaat uit 29 items (14 items competentie 'zorgproces in dialoog'; 7 items competentie 'ondersteunen cliëntparticipatie'; en 8 items competentie 'omgaan met spanningsvelden'). De construct validiteit, interne consistentie en haalbaarheid lijken acceptabel. Het instrument draagt bij aan bewustwording van vereiste competenties voor cliëntgecentreerde zorg en biedt mogelijkheden tot evaluatie en kritische reflectie.

In hoofdstuk 7 wordt uitgelegd hoe de CCCQ werd ontwikkeld en getest. De CCCQ is een kort en relatief eenvoudig instrument dat gebruikt kan worden om de 'cliëntgecentreerdheid' van de thuiszorg, zoals ervaren door de cliënt, te evalueren. Het instrument bevat 15 items. Deze zijn een operationalisatie van de waarden van de cliënt zoals geïdentificeerd in hoofdstuk 2 en van de cliëntdoelen zoals vastgesteld in hoofdstuk 5 . Het kan gebruikt worden voor evaluatie van effecten van interventies gericht op het verbeteren van cliëntgecentreerde zorg volgens het clientenperspectief. Evaluatie van cliëntgecentreerde zorg vanuit het cliëntenperspectief is in toenemende mate van belang, en deze vragenlijst biedt thuiszorgorganisaties de mogelijkheid om de geboden zorg evalueren. De antwoorden van cliënten geven aanwijzingen voor verbetering van cliëntgecentreerde zorg.

Hoofdstuk 8 beschrijft hoe de impact van het leertraject werd geëvalueerd op drie niveaus: leerprocessen, toepassing van competenties en door de cliënt ervaren cliëntgerichtheid, aan de hand van het Acht-velden model van Kessels. Drie thuiszorgorganisaties waren betrokken in het evaluatieonderzoek. In totaal 175 medewerkers volgden de basismodule, 34 verpleegkundigen en verzorgenden volgden de vervolgmodule. In totaal waren 107 cliënten betrokken bij het onderzoek. De bevindingen wijzen op een positieve impact op twee niveaus: het leerproces en de uitvoering van competenties in de praktijk. Er werd geen statistisch significante impact gevonden bij cliënten twee maanden na beëindiging van het leertraject. De procesevaluatie maakte duidelijk dat de verplegenden knelpunten ervoeren in de toepassing van cliëntgecentreerde zorg, die niet konden worden opgelost met uitsluitend acties van de verplegenden. Bovendien bleek de invloed van de getrainde verplegenden op collega's en managers beperkt. De verwachting is dat de impact van het leertraject bij cliënten zichtbaar zal worden indien meer verplegenden deelnemen aan het leertraject, en indien de implementatie ondersteund wordt door beleid, structuur en processen op alle niveaus van de zorgorganisatie. De procesevaluatie voorziet in kennis over 
voorwaarden voor leerprocessen en voor toepassing van de competenties in de praktijk. Belemmerende factoren bij het leerproces zijn gebrek aan tijd en een lager opleidingsniveau. Belemmerende factoren voor toepassing in de praktijk zijn een centrale planning, taakgericht verpleegsysteem, te hoge werkdruk en gebrek aan steun van collega's en managers. Bevorderende factoren zijn feedback van ervaringsdeskundige cliënten en mantelzorgers, kritische reflectie, discussies en moreel beraad, steun van een voor dit doel opgerichte implementatiegroep binnen de zorgorganisatie, voldoende tijd, en steun van collega's en managers.

In hoofdstuk 9 worden de resultaten van de studie besproken alsmede enkele theoretische, ethische en methodologische reflecties. Deze studie biedt meer inzicht in perspectieven op cliëntgecentreerde zorg en het leren balanceren hiertussen. Cliëntgecentreerde zorg komt in dit onderzoek naar voren als een complex, contextueel en relationeel proces waarin de verplegende en de cliënt participeren op unieke wijze. Drie patronen werden onderscheiden als cliëntgecentreerde zorg: 'consumeren', ‘dialoog' en 'instemming'. Het parapluconcept 'cliëntgecentreerde zorg' werd gekozen omdat het alle drie de patronen omvat. De dialoog is nauw verwant met het concept vraaggerichte zorg. Consumeren is nauw verwant met het concept vraaggestuurde zorg. Instemming is nauw verwant met gematigd paternalisme. Competenties van verplegenden bij het vinden van een effectieve balans zijn nauw verwant met het concept professionaliteit. Deze studie biedt meer inzicht in competenties van verplegenden en in beïnvloedende factoren bij de ontwikkeling en toepassing van deze competenties.

De bevindingen van het onderzoek benadrukken de ethische betekenis van clientgecentreerde zorg. De bevindingen ten aanzien van cliëntgerichte zorg worden besproken in het licht van vier centrale stromingen in de ethiek: de principe- ethiek, zorgethiek, fenomenologische benadering en verpleegkundige ethiek. De liberale benadering van autonomie (autonomie als negatieve vrijheid, gekenmerkt door zelfbeschikking en vrijheid van interventie door derden) en de fenomenologische benadering (autonomie als positieve vrijheid, gekenmerkt door autonomie als identificatie) vullen elkaar aan. Beide benaderingen bieden inzicht en ondersteuning bij het helpen van de cliënt om zijn/ haar autonomie te realiseren. De fenomenologische benadering is onmisbaar waar het gaat om begrip voor het dynamisch karakter van de behoeften van de individuele cliënt in zijn/ haar context. De zorgethiek en verpleegkundige ethiek zijn met name waardevol bij het nadenken over de gewenste zorgrelatie met de cliënt in de context van de dagelijkse zorg.

Sterke kanten van het kwalitatieve onderzoek zijn de betrokkenheid van cliënten, het gekozen design dat leidt tot de ontwikkeling van concepten die passen in de praktijk, triangulatie van methoden en het bespreken van resultaten 
met collega-deskundigen. De verklarende waarde en de overdraagbaarheid van de bevindingen lijkt acceptabel tot goed, mede door de selectie van situaties en respondenten gericht op het verkrijgen van een goede afspiegeling van de onderzoeksgroep en context, en door de nauwkeurige beschrijving hiervan. De variatie was enigszins beperkt wat betreft geslacht en opleidingsniveau. De ontwikkelde theoretische concepten en de gevonden relaties tussen de concepten vereisen nader onderzoek.

Sterke kanten van het ontwikkelde leertraject zijn de interne en externe consistentie, onder meer door de betrokkenheid van cliënten. Een beperking van het leertraject is de afbakening van de bevordering van cliëntgecentreerde zorg tot competentieontwikkeling van verplegenden. Een belemmerende factor was het spanningsveld tussen enerzijds benodigde tijd voor zorgvuldige analyse van kwalitatieve data en anderzijds tijdsdruk met betrekking tot de ontwikkeling van het leertraject.

Sterke kanten van het kwantitatieve deel van het onderzoek zijn de evaluatie op meerdere niveaus, de inhoudsvaliditeit van de ontwikkelde meetinstrumenten, en de formulering van de items van de competentieschaal in termen van gedrag. De onderzoeken waren beperkt vanwege de omvang van de steekproeven, het ontbreken van een controlegroep en het ontbreken van herhaalde nametingen. Alhoewel de kwantitatieve onderzoeken over het algemeen genomen niet stevig genoeg zijn voor krachtige generalisaties, zijn de eerste resultaten veelbelovend.

Het proefschrift besluit met een aantal aanbevelingen. Voor de beroepsuitoefening in de praktijk wordt zowel een relationele als een contextuele benadering aanbevolen. Bij een relationele benadering geeft verplegende het zorgproces gestalte in relatie met de cliënt. In een contextuele benadering komt de verplegende tegemoet aan de door de individuele cliënt gewenste participatie, rekening houdend met de competenties van de cliënt om te participeren en rekening houdend met overige rollen en verantwoordelijkheden van de verplegende. Feedback, kritische reflectie en moreel beraad met collega's zijn van groot belang. Met betrekking tot de opleiding van verplegenden wordt de ontwikkeling van de competenties 'zorgproces in dialoog', 'faciliteren van cliëntparticipatie' en 'omgaan met spanningsvelden' aanbevolen. De competentieontwikkeling dient aan te sluiten bij de leerbehoeften van de individuele zorgverlener.

Beleidsmakers wordt aanbevolen om spraakverwarring rond het concept cliëntgecentreerde zorg en aanverwante zorgconcepten te voorkomen door het centrale perspectief, niveau en aspecten van cliëntgecentreerde zorg te verduidelijken. Het bevorderen van het bewustzijn van de attitude van alle werknemers van de zorgorganisatie ten aanzien van de centrale positie van de cliënt en zijn/haar vraag wordt aanbevolen door middel van communicatie op reguliere basis over ervaringen, verwachtingen en best practices. Managers dienen 
cliëntgecentreerde zorg in het primaire proces te bevorderen door de professionele autonomie van de zorgverlener te bevorderen en door verplegenden te steunen met betrekking tot besluiten over zorg in de specifieke context. Cliëntgecentreerde zorg in het primaire proces dient ingebed te zijn in beleid, structuren en processen van betrokken personen op alle niveaus van de zorgorganisatie. Beleidsmakers wordt aanbevolen om te erkennen dat cliënten verschillen wat betreft de wijze waarop zij wensen te participeren in de zorg.

Nader onderzoek naar de ontwikkelde theoretische concepten en relaties tussen de concepten wordt aanbevolen. Nader onderzoek wordt eveneens aanbevolen naar de impact van cliëntgecentreerde zorg op cliënten en op verpleegkundigen en naar de relatie met achtergrondvariabelen zoals opleidingsniveau van verplegenden. Het verder testen van de validiteit, betrouwbaarheid en responsiviteit van de ontwikkelde meetinstrumenten is noodzakelijk. Het perspectief op cliëntgecentreerde zorg van cliënten en verplegenden in de context van acute zorg verdient aandacht. Onderzoek naar de morele ontwikkeling van verplegenden en de ontwikkeling van normatieve richtlijnen voor verplegenden kan zorgverleners mogelijk ondersteunen in het verlenen van cliëntgecentreerde zorg. Verder onderzoek naar aanvullende interventies gericht op implementatie van cliëntgecentreerde zorg wordt aanbevolen. 


\section{DANKWOORD}

Het begon allemaal als een kans die voorbij kwam om mij te ontwikkelen als onderzoeker, die ik gegrepen heb. Zonder het verschijnsel 'kenniskring' onder begeleiding van een 'lector' zou het nooit in me opgekomen zijn om een dergelijk traject te starten. Ik zie kenniskringen als een fantastische mogelijkheid voor docenten in het $\mathrm{HBO}$ om hun competenties ten aanzien van wetenschappelijk onderzoek verder te ontwikkelen in een inspirerende omgeving, onder deskundige begeleiding.

Mijn voortraject als verpleegkundige en als docent bleek een prachtige aanloop te zijn geweest naar deze uitdaging. Het maakte mij gevoelig voor de inhoudelijke thematiek. In mijn werk als docent werd ik regelmatig geconfronteerd met de vraag hoe het professionele perspectief op zorg (verpleegkundige diagnosen en evidence-based practice) te combineren valt met het perspectief van de cliënt op zorg, en hoe dit te vertalen naar competentie-ontwikkeling van studenten. Door de uitvoering van het onderzoek in dit proefschrift kon ik op wetenschappelijke wijze met deze inhoudelijke vragen bezig zijn.

Het samenwerken aan deze klus met verschillende mensen werkte verrijkend, stimulerend en motiverend. Iedereen die direct of indirect heeft bijgedragen wil ik daarvoor bedanken.

In het bijzonder wil ik alle betrokken cliënten, hun naasten, de betrokken verpleegkundigen en verzorgenden en hun managers danken dat zij hun gevoelens, gedachten en ervaringen met mij hebben willen delen.

Twee co-promotoren en één promotor begeleidden mij gedurende het traject. Zij vulden elkaar perfect aan. Ruud ter Meulen, mijn promotor, kwam in de picture bij een presentatie over de betekenis van het begrip autonomie voor de hulpverlening aan chronisch zieken. Ruud, gaandeweg het proefschrift bleek jouw deelname zeer waardevol, omdat de rol van ethiek in de thematiek van dit proefschrift steeds duidelijker werd. Je was kritisch en stimulerend en had met name oog voor de grote lijn van het project. Door je vertrek naar de universiteit van Bristol volgde je de laatste ontwikkelingen van grotere afstand, en werd het Engelstalig perspectief toegevoegd aan je feedback op de door mij ingeleverde stukken. Dankje voor je deskundige bijdrage. Ireen Proot was mijn co-promotor en leermeester in het uitvoeren van goed kwalitatief onderzoek volgens de grounded theory benadering. Ireen, je was altijd bereid om je methodologische en inhoudelijke deskundigheid met me te delen. Je deelde ook je enthousiasme voor het vak met mij. Je gedegen, zorgvuldige en kritische blik hebben me vaak 
en veel verder geholpen, zowel wat betreft de analyses, als wat betreft publicaties. Naast ons enthousiasme voor het vak hadden we rakvlakken in de zorg om het behoud van autonomie van onze moeders. Ik kijk terug op een zeer leerzaam proces en dank je voor je rol daarin. Luc de Witte, lector van de kenniskring Autonomie en participatie van chronisch zieken en projectleider van de ontwikkeling van het leertraject was als co-promotor belast met de dagelijkse begeleiding en met kwantitatieve deel van het traject. Je was de inspirator van het gehele traject. Je bleek zeer betrokken bij de doelgroep van chronisch zieken en bij het centrale thema, en deskundig in kwantitatieve onderzoekstechnieken. Ondanks je zeer drukke werk en leven heb ik veel steun van je gehad, zowel inhoudelijk als methodologisch. Ten aanzien van mijn leerproces was je stimulerend, enthousiast, kritisch, resultaatgericht en creatief. Af en toe werd ik gemaand 'niet te moeilijk te doen', en het eenvoudig te houden. Je bood veel vertrouwen en ruimte voor eigen keuzes. Je stelde je op als gelijkwaardige partner in de samenwerking. Dank je hiervoor.

Het hart van het onderzoek was de ontwikkeling, uitvoering en evaluatie van het leertraject 'Zorg in Dialoog'. De ontwikkelaars en docenten van dit leertraject zijn van grote waarde geweest voor dit proefschrift. Jeanny Engels, Marja Legius, Math Hirsch, Trudy Leerink en Henk van den Biggelaar, ik dank jullie van harte voor de vele inspirerende discussies, de samenwerking en voor jullie bijdrage aan de dataverzameling. Het leertraject is een mooi gezamenlijk produkt geworden. Vele personen fungeerden als kritische en betrokken leden in de stuurgroep en klankbordgroep en als ervaringsdeskundigen vanuit de CG-Raad. Al deze mensen samen brachten hun eigen specifieke deskundigheid in dit project. Ik wil hen bedanken voor de waardevolle samenwerking.

Het was onmogelijk geweest om het onderzoek af te stemmen op de mogelijkheden van de praktijk zonder de gedreven en enthousiaste hulp van de contactpersonen van de betrokken thuizorgorganisaties: Jacqueline Vestjens en Olga de Jager van Thuiszorg midden-Limburg; Petra Noordzij van ZuidZorg (voorheenThuiszorg Kempenstreek), Christel Jenneskens van Groene Kruis Zorg; en Jacqueline Kammenga van Thuiszorg Oostelijk Zuid-Limburg. Met name door het kwalitatieve karakter van de diverse onderzoeken bleek jullie flexibiliteit en creativiteit bij de selectie van patiënten en verplegenden, en bij het inpassen van activiteiten in de organisatie van onschatbare waarde. Ik dank jullie en jullie managers heel hartelijk voor jullie medewerking.

Ik dank de diverse managers en het College van Bestuur van de Hogeschool Zuyd voor hun faciliterende en creatieve rol bij dit promotietraject. Een speciaal woord van dank voor Frits Benjamins, directeur van de Faculteit Gezondheid en 
Zorg, Giel Vaessen, manager van de Businessunit Zorg en Jos Willems, lid van het College van Bestuur.

Het was een traject van trial en error, mede doordat de hogeschool nog niet ingesteld was op dergelijke trajecten en diverse randvoorwaarden gaandeweg gerealiseerd dienden te worden. Ik dank alle medewerkers van de ondersteunende diensten voor hun ondersteuning. Een speciaal woord van dank aanYolande Keulers en Annelies Gielgens voor de secretariële ondersteuning; Saskia Gijselhart en Dirk van den Hoogen van Bureau onderzoeksverwerking Audit\&Control; Jof Krahmer en Liesbeth Ramaekers van de mediatheek.

De kenniskring bleek een bron van steun en voorzag in diverse 'rolmodellen' en deskundigen. Ik dank jullie allen voor jullie kritische reacties en ondersteuning. Ik dank Mieke le Granse voor haar morele en inhoudelijke steun in de beginperiode. Ook mijn 'lotgenoten' die gaandeweg hetzelfde traject ingingen wil ik noemen. Ruth Dahlemans en Susy Braun,wij waren dan wel geen aio's aan de universiteit, wij aten wel eens samen soep, deelden de rol van $\mathrm{PhD}$ student, en de hierbij komende frustraties en knelpunten. Ik heb de onderlinge openheid en hulp erg gewaardeerd.

$\mathrm{Nu}$ toegepast onderzoek officieel een kerntaak van hogescholen is geworden, en de Hogeschool Zuyd zich ten doel heeft gesteld om promotietrajecten te continueren en uit te breiden zullen velen mij volgen. Ik wens hen allen een meer gebaand pad en een cultuur van onderlinge steun.

Alle collega's van de faculteit Gezondheid en Zorg, en vooral mijn kamergenoten wil ik hartelijk danken voor hun belangstelling en medeleven. Enkele collega's die ik nog niet genoemd heb wil ik daarbij bijzonder danken voor de steun en gezelligheid: Ton Korsten, Annelies Geerbex, Ruud Heijnen en Hans van Drongelen.

Diverse mensen waren vanwege hun specifieke deskundigheid betrokken bij elementen van het traject. Ik dank Joseph Kessels voor zijn bereidheid kritisch te discussiëren over het gebruik van zijn model in deze studie, en voor zijn kritische reflectie. Ik dank Louk Hollands, deskundige op het gebied van competentieontwikkeling en mijn medestander in het gebruik van het model van Kessels. GodeliefMars, nog een lotgenoot, bedankt voor je leerzame bijdrage aan de analyse van een van de studies. Ik dank Gabriëlle Verbeek en Elsbeth Oostendorp, twee inhoudsdeskundigen rond vraaggerichte zorg, omdat zij hun kennis en ervaring met mij wilden delen. Ook Conny Bellemakers en Marja Morskieft, ervaringsdeskundigen, dank ik dat zij hun inzichten met mij hebben willen delen. MarieJosée Smits dank ik voor de leerzame discussies over modellen voor moreel 
beraad. Bob Wilkinson wil ik danken voor de lessen wetenschappelijk Engels en de deskundige, geduldige en nauwgezette correcties van mijn Engelse teksten.

Vanaf het begin maakte mijn broer Hugo Schoot al duidelijk dat hij graag mijn paranymf wilde zijn. Bedankt Huug voor deze eer en voor je betrokkenheid en je steun. Mijn vriendin Jeanine Bonestroo is mijn tweede paranymf. Als dierenarts en als mens herken jij veel van de centrale thematiek. Ik denk dat menig zorgverlener nog veel van jouw belangstelling en warmte voor mensen zou kunnen leren. Ik ben erg benieuwd naar de ivoren toren die je voor me hebt gemaakt. Fijn dat jullie twee naast mij willen staan.

Mijn familie, schoonfamilie, vrienden en vriendinnen hebben de afgelopen jaren steeds weer geïnformeerd naar de vorderingen, belangstelling getoond, met me meegeleefd, relativerende opmerkingen gemaakt en voor de broodnodige ontspanning gezorgd. Dank daarvoor.

Mijn vader die in 1987 overleden is en mijn moeder, die kampt met problemen met haar gezondheid hebben mij ook laten voelen wat het betekent om je eigen autonomie te behouden en welke rol zorgverleners daarin kunnen spelen. Ik denk dat ze trots op mij zijn/ zouden zijn geweest.

En dan het thuisfront: zonder jullie acceptatie zou het niet zijn gelukt, en vooral... door jullie is het leuk gebleven. Sanne en Veerle, ik vind het heel bijzonder dat jullie accepteerden dat ik vaak zat te werken. Jullie vonden het wel cool wat ik deed. Bedankt voor de ruimte die jullie me gaven. Ben, bedankt voor je onvoorwaardelijke geloof in mijn mogelijkheden, voor je stimulerende maar ook relativerende en confronterende opmerkingen als ik weer eens veel te lang doorging. Ook dank voor de inzet van je deskundigheid als onderwijskundige.

Ook voor al die anderen die meeleefden en meewerkten, maar die in dit dankwoord niet zijn genoemd. Dank je wel! 


\section{CURRICULUM VITAE}

Tineke Schoot was born on November, 9, 1956 in Maastricht, the Netherlands. In 1975 she completed secondary school at the 'Stedelijk Lyceum' in Maastricht. She studied nursing, graduating with a Bachelor's degree (HBOV) at the Gezondheidszorgacademie in Nijmegen (1975-1979). Her thesis for this study was published in 1980. From 1979 till 1980 she worked as a nurse at the 'Radboudziekenhuis', division gastro-enterology. In 1980 she moved to Switzerland. For one year she worked at the Centre Hospitalière Universitaire Vaudoise in Lausanne as a unit manager in physiatrics / geriatrics, and later as a staff nurse in pediatrics, medium care. In 1981 she started as a community health nurse at Groene Kruis Heuvelland, where she worked for the next five years. In 1985 she started the full-time study Health Sciences, specializing in nursing science at the Maastricht University. During her study, Tineke Schoot married to Ben Nolet, and their daughters were born in 1987 and 1989. After graduation in 1989 she started working as a lecturer at the Zuyd University, Heerlen, in the department of nursing. She was a member of the project group concerned with implementing problem-based learning in the nursing curriculum, starting in 1990. As a senior lecturer she was mainly involved in modules on nursing research, quality care, and clinical reasoning. In 2000 she published a book on clinical reasoning in dialogue with the patient. She co-ordinated quality care of the faculty of health from 1997 till 2001. She participated in the national innovation project 'Professional Competencies of nurses with a Bachelor's degree' (2000-2002). During 2001 she co-ordinated the development and implementation of the Centre of Expertise on Autonomy and Participation. In 2002 she started with her Ph.D. study. She is currently working as a senior lecturer in the master's programme 'Advanced Nursing Practice'. From 2006 she will co-ordinate the division 'Client-Centred Care' of the Centre of Expertise on Autonomy and Participation. 


\section{PUBLICATIONS}

Schoot, T. (1980). Geefborstvoeding de kans (Give breastfeeding a chance). In E. de Haan \& T. Schoot (Eds.), Prenatale zorg en borstvoeding (Prenatal care and Breastfeeding). Lochem: De Tijdstoom.

Schoot, T., Danen, S., Koetsenruijter, R., Schepers, A., Jonkers, A., \& van Swieten, B. (2006). De verpleegkundige als ontwerper. Utrecht: ThiemeMeulenhoff.

Schoot, T., Engels, J., Hollands, L., \& de Witte, L. (2004). Het ontwerp van een leertraject in samenspraak (The design of a learning programme in dialogue). Onderwijs en Gezondheidszorg(6), 3-10.

Schoot, T., Engels, J., Legius, M., Leerink, T., van den Biggelaar, H., \& de Witte, L. (2004). Zorg in Dialoog: Vraaggerichte zorg door verpleegkundigen en verzorgenden. Procesevaluatie. Hoensbroek: Instituut Kenniscentrum voor Revalidatie en Handicap.

Schoot, T., Hirsch, M., \& de Witte, L. (2005). Development of competencies aimed at client-centred care: An evaluation study of a learning programme for Dutch community nurses. Submitted.

Schoot, T., le Granse, M., Lambert, J., Steinbusch, L., \& Wolters, P. (2001). Projectplan Kenniskring/Lectoraat 'Autonomie en participatie': De bijdrage van lifesciences en professionals aan de autonomie en participatie van chronisch zieken. Heerlen: Hogesschool Zuyd, Faculteit Gezondheidszorg.

Schoot, T., Proot, I., \& de Witte, L. (2006). Zelfbeoordeling van competenties voor vraaggerichte zorg in de thuiszorg. De ontwikkeling van de Zorg in dialoog Competentie Schaal. Verpleegkunde, 3. In press.

Schoot, T., Proot, I., Legius, M., ter Meulen, R., \& de Witte, L. (2005). Clientcentred home care: Balancing between competing responsibilities. Clinical Nursing Research, 15(4), 1-24..

Schoot, T., Proot, I., ter Meulen, R., \& de Witte, L. (2005). Actual Interaction and client-centredness in home-care. Clinical Nursing Research, 14(4), 370393.

Schoot, T., Proot, I., ter Meulen, R., \& de Witte, L. (2005). Recognition of client values as a basis for tailored care: the view of Dutch expert patients and family caregivers. Scandinavian Journal of Caring Sciences, 19, 169-176.

Schoot, T., \& Stevens, P. (2000). Ontwerpen van zorg vanuit verpleegkundig perspectief. Utrecht/Zutphen: ThiemeMeulenhof.

Schoot, T., Vaessen, J., Danen, S., \& bij de Vaate, E. (2006). Deverpleegkundige als zorgverlener. Utrecht: ThiemeMeulenhoff.

Witte, de L. P., Schoot, C. M., \& Proot, I. P. (2006). Evaluating clientcentredness of home-nursing care: Development of the Client-Centred Care Questionnaire (CCCQ). Journal of Advanced Nursing, Accepted for publication. 